\title{
Yakhtashian (Artinskian-Early Kungurian) cyanobacteria and calcareous algae from the Carnic Alps (Austria/ltaly)
}

\author{
Karl Krainer, Daniel Vachard, and Maria Schaffhauser
}

\begin{abstract}
The Lower Permian calcareous algae are revised in the Zweikofel, Zottachkopf and Trogkofel formations of the Carnic Alps (Austria-Italy border). The cyanobacteria and red algae are Nostocites, Archaeolithoporella, Renalcis, Gahkumella, Koivaella, Girvanella, Mitcheldeania, Clinortonella, Garwoodia, Parachaetetes, and Archaeolithophyllum lamellosum Wray. Among the possible Bryopsidales, Homannisiphon is emphasized, and the phylloid algae are formally assigned to the family Anchicodiaceae emend. with the tribe Anchicodiae nomen translatum synonymized with Ivanoviae, and the genera Anchicodium, Kansaphyllum, Iranophyllum, Ivanovia, Eugonophyllum, Calcipatera, and Neoanchicodium. The new and emended species of phylloid algae are Eugonophyllum magnum (Endo) emend. (synonymous with Succodium duisbergi Homann), and Calcipatera schoenlaubi n. sp. Among the Dasycladales, the tribe Anthracoporellae n. trib. is described; the epimastoporaceans are revised; and Gyroporella, Macroporella, Mizzia and Connexia are mentioned. Among the Epimastoporaceae, the genera Epimastopora, Epimastoporella, Globuliferoporella and Pseudoepimastopora are emended and re-described as Epimastopora emend., Epiastopora n. gen., Pseudoepimastopora emend., and Globuliferoporella emend. Epimastopora japonica Endo is formally designated as the type species of Epimastopora emend.; E. likana Kochansky and Herak and E. cf. izawaikensis Endo are other regional representatives of Epimastopora emend.; Globuliferoporella piai (Kordé) n. comb. emend. is proposed as type species in replacement of G. symmetrica sensu Chuvashov non Johnson; and Atractyliopsis carnica Flügel is re-assigned to Pseudoepimastopora emend. Among the Algospongia, the genera Claracrusta, Ungdarella and Efluegelia are analyzed. Flügel's "Algen Sporen" are interpreted as desmae of sponges. Pseudovermiporellids, tubiphytids and ellesmerellids, considered here as foraminifers, are described in a second paper.
\end{abstract}

Karl Krainer. Institute of Geology, University of Innsbruck, Innrain 52, A-6020 Innsbruck, Austria. Karl.Krainer@uibk.ac.at

Daniel Vachard. Collegial and International Research Centre of Active Seniors (CIRCAS), 1 rue desTilleuls, 59152 Gruson, France. Daniel.Vachard@free.fr

Maria Schaffhauser, Tiroler Landesmuseum, Fachbereich Erdwissenschaften, Krajnc Straße 1, 6060 Hall, Austria. M.Schaffhauser@tiroler-landesmuseen.at

Krainer, Karl, Vachard, Daniel, and Schaffhauser, Maria. 2019. Yakhtashian (Artinskian-Early Kungurian) cyanobacteria and calcareous algae from the Carnic Alps (Austria/ltaly). Palaeontologia Electronica 22.3.54A 1-107. https://doi.org/10.26879/931 palaeo-electronica.org/content/2019/2655-yakhtashian-algae-carnic-alps 
Keywords: Early Permian; cyanobacteria; algae; Rattendorf Group; Trogkofel Formation; Carnic Alps, Austria, Italy; new genus

Submission: 11 October 2018. Acceptance: 10 July 2019.

\section{INTRODUCTION}

Algae from the Carnic Alps and Karawanken Mountains (Austria, Italy and Slovenia) have been described, for more than one century, by Gortani (1906); Pia (1937); Kochansky-Devidé (1970a, 1979); Homann (1972); Flügel (1979, 1980, 1981); Flügel and Flügel-Kahler (1980); Flügel et al. (1997); Krainer (1991, 1993, 1995a); Samankassou (1997a, 1997b); Krainer et al. (2003b); Forke and Samankassou (2000); Vachard and Krainer (2001a, 2001b); and Schönlaub and Forke (2007). However, these authors described calcareous algae only from parts of the lower Permian succession of the Carnic Alps or presented a brief overview. For example, calcareous algae from the Trogkofel Formation were mostly described from samples which were not collected at the type locality or type section. A type section of the Trogkofel Formation was first defined and described by Schaffhauser (2013) and Schaffhauser et al. (2015). The large number of samples (and thin sections) from the lower Permian succession, particularly from the type sections of the Zweikofel, Zottachkopf and Trogkofel formations, which were taken for microfacies and micropaleontological investigations (e.g., Krainer et al., 2009; Krainer and Schaffhauser, 2012; Schaffhauser, 2013; Schaffhauser et al., 2015), allowed us to study the algal assemblages in much more detail. We already described the latest Pennsylvanian and earliest Permian algae of the Auernig and Rattendorf groups (Vachard and Krainer 2001a, 2001b). In this paper, we present a comprehensive description of calcareous algae of the upper Cisuralian Zweikofel, Zottachkopf and Trogkofel formations in the Carnic Alps along the Austrian/Italian border (Figures 1 and 2).

\section{LOCATION AND METHODS}

The Zweikofel Formation was studied at the type section at Zweikofel (sections ZK, ZKO), Garnitzenbach (section GB, including the uppermost part of the underlying Grenzland Formation) and the Zottachkopf Formation at several sections in the Trogkofel-Zottachkopf massif where the formation underlies the massive Trogkofel Limestone. The Zottachkopf Formation was studied on the northern side (sections TNA, TNB, TNC, Z, and $Z T$ ), the southern side (section TKS) and southwestern side (section TKW) of the Trogkofel mas-

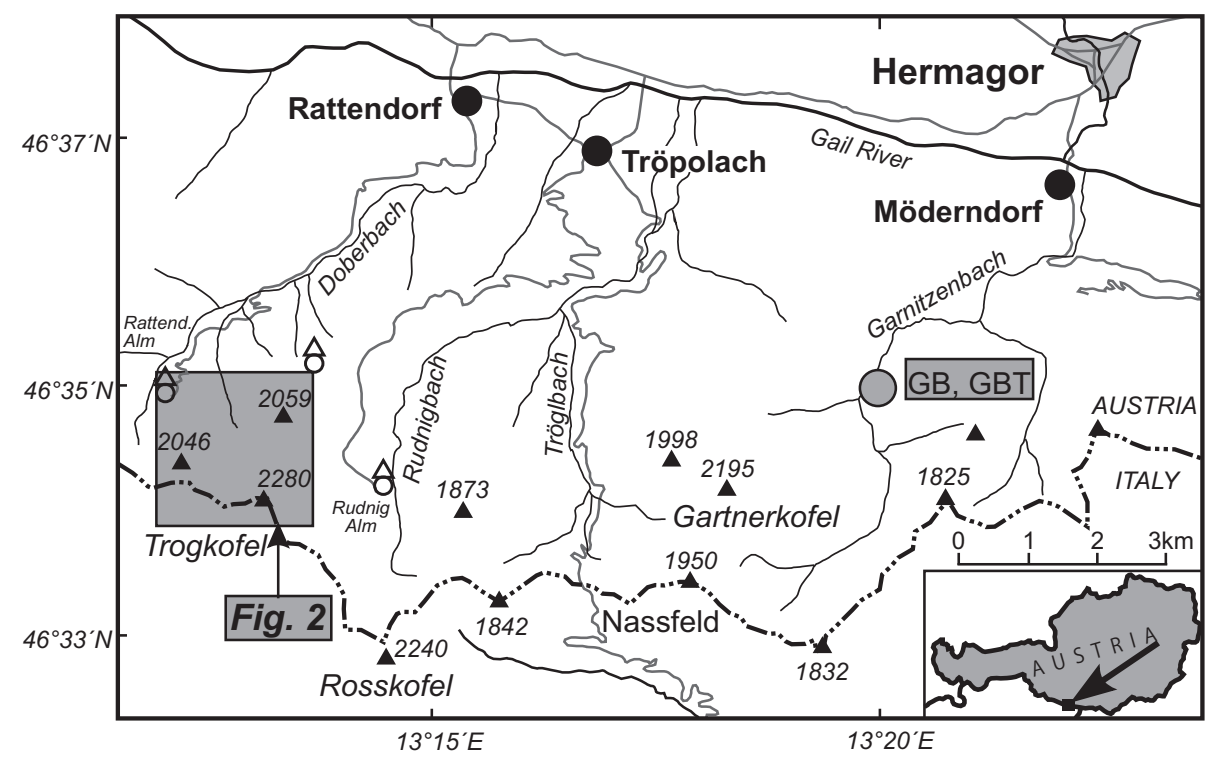

FIGURE 1. Map of the Trogkofel area in the Carnic Alps (southern Austria). GB: section Garnitzenbach of the uppermost part of the Grenzland Formation and Zweikofel Formation, GBT: Section Garnitzenbach of the Trogkofel Formation. 


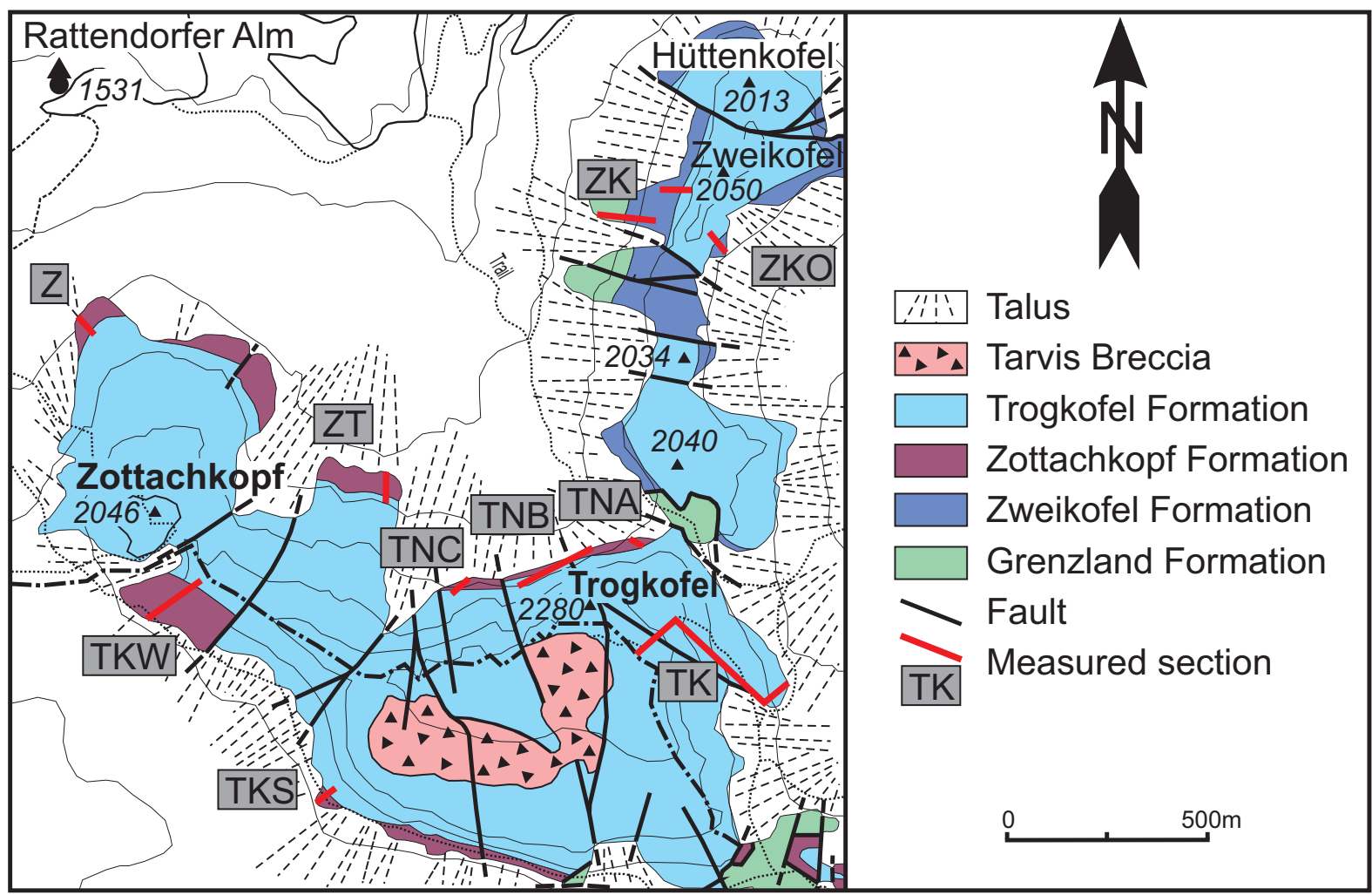

FIGURE 2. Detailed geologic map of the Trogkofel area. ZK: type section of the Zweikofel Fm, ZKO: section through the uppermost part of the Zweikofel Fm at Zweikofel East, TNA, TNB and TNC: sections of the Zottachkopf Fm on the northern side of the Trogkofel Massif, ZT: section through the upper part of the Zottachkopf Fm and basal part of the Trogkofel Fm, Z: section on the northern side of Zottachkopf through the upper part of the Zottachkopf Fm and basal Trogkofel Fm, TKW: section Trogkofel West through the uppermost part of the Zottachkopf Fm and basal part of the Trogkofel Fm, TKS: section Trogkofel South including the uppermost part of the Zottachkopf Fm and basal Trogkofel Fm; TK: type section of the Trogkofel Fm.

sif. Most of these sections include the Zottachkopf Formation and the lowermost part of the Trogkofel Formation.

The Trogkofel Formation was studied at the type section (section TK), which is exposed on the northeastern side of the Trogkofel massif. One section through part of the Trogkofel Formation was studied at Garnitzenbach (section GBT), about 10 $\mathrm{km}$ east of the Trogkofel massif (Figure 1). The basal Trogkofel Formation was studied at several sections in the Trogkofel and Zottachkopf massif. The locations of the studied sections are shown on Figures 1 and 2 .

From all sections, samples were collected from which thin sections were prepared for microfacies analysis and determination of fossils, particularly calcareous algae and foraminifers. In order to complete our biostratigraphical and taxonomical documents, we have also revisited and re-studied the sections of the Artinskian Zweikofel Formation (sections ZK and GB, Figures 1 and 2), already mentioned in Vachard and Krainer (2001b). We analyzed more than 675 thin sections in terms of microfacies and microfossils. Microfossils were described, photographed and documented in 20 plates of calcareous microflora (this work), and 47 plates of microfauna (Krainer et al., submitted).

Taxonomic descriptions and systematics follow the schemes of algal taxonomy proposed by Bassoullet et al. (1979), Bucur (1994), Granier and Grgasović (2000), and Vachard and Cózar (2010). The material is housed at Innsbruck University, Austria (collection numbers GB1-175, GBT1-11, TK 1-70, TKS1-19, TKW1-18, TM1-9, TNA1-30, TNB1-23, TNC1-11, Z1-19, ZK1-215, ZKO1-47, and $\mathrm{ZT} 1-18)$.

\section{HISTORICAL BACKGROUND}

Upper Paleozoic sediments and fossils of the Carnic Alps have been studied by Austrian, Italian and German scientists, starting with the work of Frech, Geyer, Gortani, Schellwien, Stache, Taramelli, Vinassa de Regny and others, at the end of 
the nineteenth century, and continued between the two World Wars by Heritsch, Kahler and Selli, who established the basic stratigraphic scheme summarized in Heritsch (1943). After World War II, paleontological and biostratigraphical studies as well as mapping were intensified, resulting in geological maps of the Naßfeld-Pramollo area (Kahler and Prey, 1963; Selli, 1963; Schönlaub, 1987; Venturini, 1990b; Schönlaub and Forke, 2007), refined biostratigraphical subdivisions, especially those of the Late Carboniferous and Early Permian, based on fusulinids (Kahler, 1985, 1986), as well as microfacies and facies models describing depositional patterns of reef and non-reefal shelf sediments such as those of Flügel (1971a, 1974, 1980, 1981, 1987); Buggisch et al. (1976); Buttersack and Boeckelmann (1984); Venturini, (1990a, 1991); Massari and Venturini (1990); Massari et al. (1991); Krainer (1991, 1992, 1995a, 2007); Flügel et al. (1997); Forke et al. (1998); Samankassou (1998, 1999, 2002, 2003); Krainer et al. (2003b); Sanders and Krainer (2005); Krainer and Schaffhauser (2012); Schaffhauser (2013); Schaffhauser et al. (2015). Most studies involved 1) fusulinids summarized in Kahler (1985, 1986); and completed in Forke (1995, 2000, 2002); Forke et al. (1998); Forke and Samankassou (2000); Kahler and Krainer (1993); Krainer and Davydov (1998); Davydov and Krainer (1999); and Davydov et al. (2013); 2) calcareous algae in Homann (1972); Flügel and Flügel-Kahler (1980); 3) conodonts in Forke (2002); and 4) smaller foraminifers in Vachard and Krainer (2001a, 2001b). Boersma and Fritz studied fossil plants summarized in Fritz and Krainer $(2006,2007)$. Forke et al. (2006) and Schönlaub et al. (2007) provided a summary of the Upper Paleozoic succession of the Carnic Alps.

\section{GEOLOGIC SETTING}

In the Carnic Alps, the Variscan Orogenic Phase culminated during the middle Westphalian and was followed by block- and wrench-faulting resulting in the formation of discrete sedimentary basins (Venturini, 1982, 1990a, 1991). These basins were filled with deltaic to shallow marine sediments of the Late Carboniferous Bombaso Formation and Auernig Group, and the Late Carboniferous/Early Permian Rattendorf and Trogkofel groups (Figures 3-5). This approximately $2000 \mathrm{~m}$ thick, sedimentary succession of dominantly shallow marine siliciclastic and carbonate rocks unconformably overlies the folded Variscan basement. The succession is of Middle Pennsylvanian (latest Moscovian) to Early Permian (Kungurian) age and was deposited in sedimentary basins that formed by block faulting during the Westphalian. The succession is divided into the Bombaso Formation (= Collendiaul Formation and Malinfier Formation, according to Schönlaub and Forke, 2007), Auernig Group (or Auernig Formation according to Schönlaub and Forke, 2007), Rattendorf Group and Trogkofel Group; summaries of which were given in Schönlaub and Forke (2007).

The Auernig and Rattendorf groups are composed of mixed siliciclastic-carbonate shelf deposits forming well-developed cycles. Thanks to the rich fusulinid fauna, the Auernig Group is dated as Kasimovian and Gzhelian (Kahler, 1983a, 1985, 1986, 1989; Krainer and Davydov, 1998). Plant fossils, which are known from many localities and different stratigraphic levels throughout the succession, indicate a Stephanian age (Fritz et al., 1990; Fritz and Krainer, 1993, 1994, 1995, 2006, 2007).

The Auernig Group is conformably overlain by the Rattendorf Group, which is divided into the Schulterkofel Formation (Lower Pseudoschwagerina Limestone: abbreviated into LPL, LP or UPK), Grenzland Formation and Zweikofel Formation (Upper Pseudoschwagerina Limestone: abbreviated into UP, UPL or OPK). Recently, Schaffhauser et al. (2010) introduced the Zottachkopf Formation, which underlies the Trogkofel Formation in the Trogkofel massif, differs in facies and is probably younger than the Zweikofel Formation. The Zweikofel and Zottachkopf formations are overlain by the Trogkofel Formation.

\section{CISURALIAN RATTENDORF GROUP AND TROGKOFEL FORMATION}

\section{Rattendorf Group}

The Rattendorf Group consists of shallow marine carbonate and siliciclastic sediments of nearshore, inner shelf and outer shelf environments. The succession is divided into the Schulterkofel, Grenzland, Zweikofel and Zottachkopf formations.

\section{Schulterkofel Formation}

At the type section, the Schulterkofel Formation is approximately $137 \mathrm{~m}$ thick and composed of three depositional cycles consisting of shallow marine limestones and thin siliciclastic intervals (mostly sandstone), which form the bases of the depositional sequences and were deposited during relative sea-level lowstands. During transgression, well-bedded fossiliferous limestones and massive algal mounds accumulated (Krainer et al., 2003b). Bedded cherty limestones with marl intercalations 


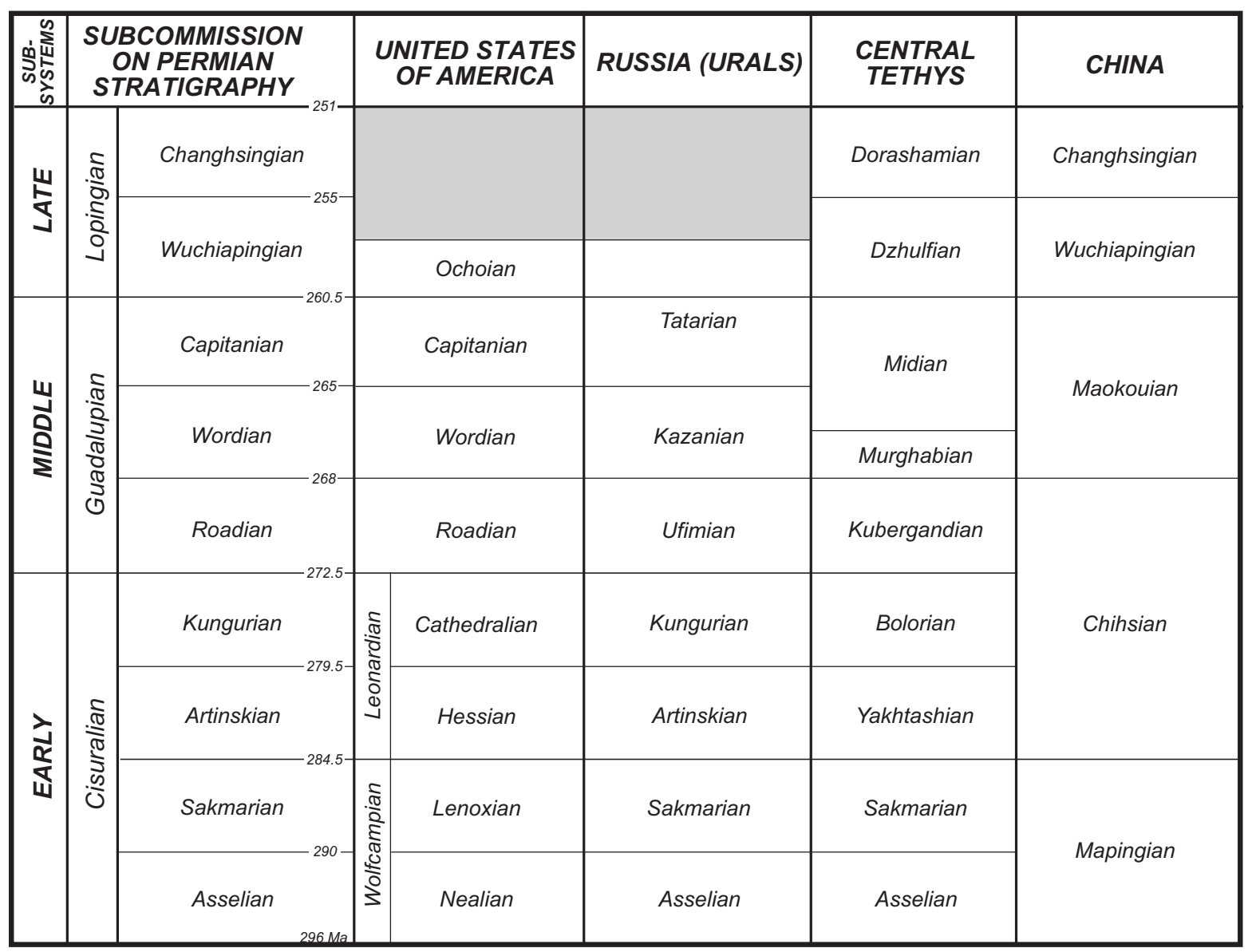

FIGURE 3. Correlation of Permian stages.

are interpreted to have been deposited during relative sea-level highstands with water depths of some tens of meters. Fusulinid-rich limestone beds are present at different stratigraphic levels, particularly at the base and on top of the siliciclastic intervals. Fusulinids of these beds are considered as parautochthonous assemblages, accumulated during periods of low sediment input (Buggisch et al., 1976, Flügel, 1974, 1977; Forke et al., 1998; Homann, 1969; Samankassou, 1997a, 1999).

\section{Grenzland Formation}

The Lower Permian (Asselian-Sakmarian) Grenzland Formation of the Rattendorf Group, is exposed along the Austrian/Italian border. The Grenzland Formation is more than $300 \mathrm{~m}$ thick, and is composed of siliciclastic sediments and intercalated fossiliferous limestone. A complete section is not exposed; data are derived from several sub-sections. There is no overlap between the individual subsections.

The lower part (50-100 m), which conformably rests on fossiliferous limestone of the Schul- terkofel Formation, is non-cyclic, entirely siliciclastic and composed of siltstone, sandstone and rare fine-grained conglomerate. Siltstone locally contains brachiopods, crinoid fragments and abundant trace fossils (mainly Zoophycos), and sandstone commonly displays hummocky crossbedding.

The middle $(\sim 175 \mathrm{~m})$ and upper parts $(\sim 105$ $\mathrm{m})$ are a cyclic succession of quartz-rich conglomerate and crossbedded sandstone of a nearshore facies, hummocky crossbedded sandstone of the lower shoreface, offshore siltstone and shale and fossiliferous limestone forming well-developed parasequences. The upper part is conformably overlain by the Zweikofel Formation. In the middle and upper parts, at least 15 cycles (parasequences) are recognized, and the thickness of these parasequences ranges from approximately 10 to $30 \mathrm{~m}$. A cyclic sequence is predominantly composed of shallow marine siliciclastic sediments (quartz-rich conglomerates, sandstones and siltstones) and intercalated, thin, fossiliferous limestone intervals (Buttersack and Boeckelmann, 


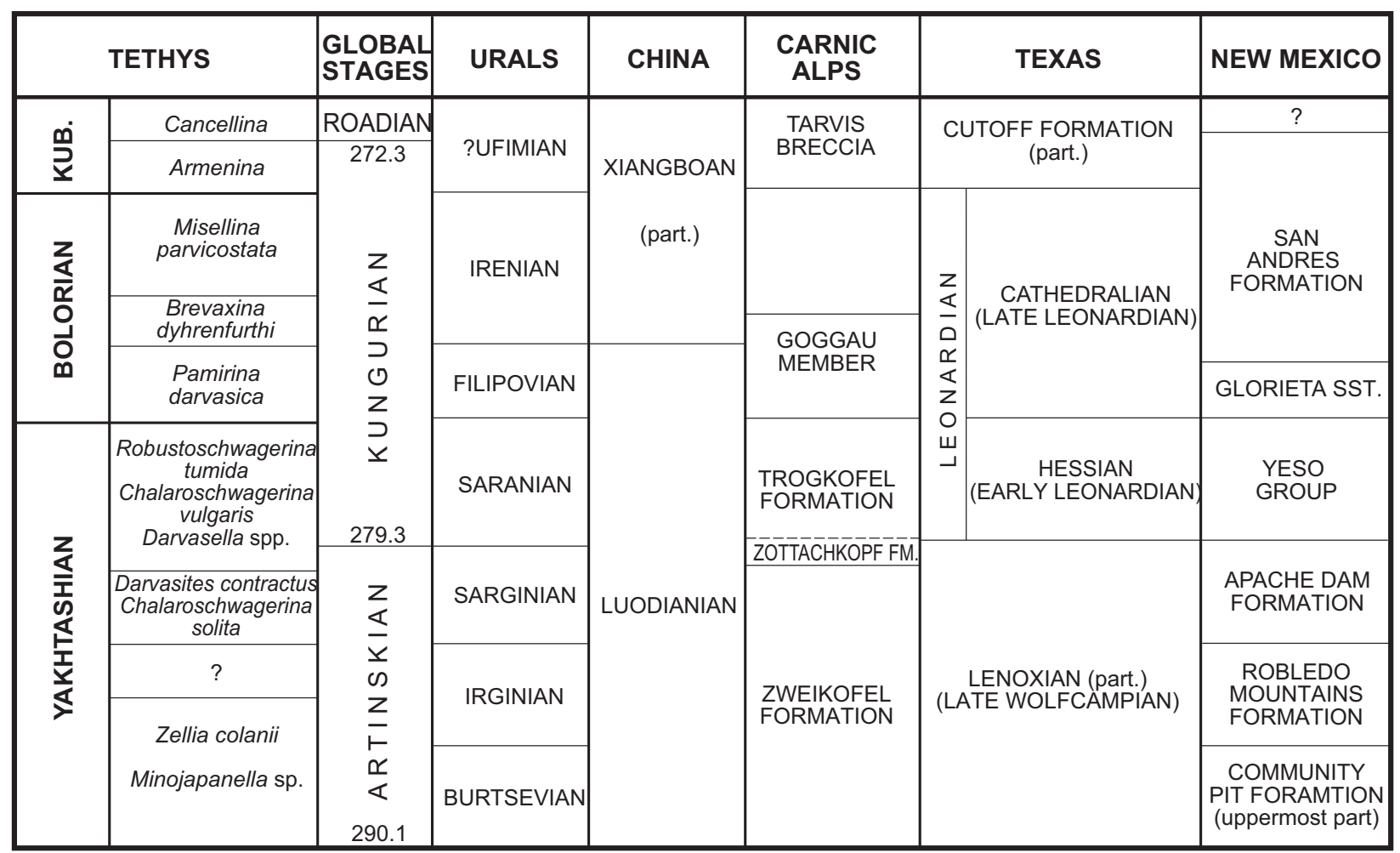

FIGURE 4. Correlation of Yakhtashian and Bolorian regional stages.

1984; Boeckelmann, 1985). In the upper part a thin interval of nonmarine fine-grained red beds with an intercalated pedogenic limestone is present. A caliche horizon and a red shale horizon with scattered angular quartz grains in the upper part of the sequence point to subaerial exposure. Plant fossils have been described from a thin shale intercalation by Fritz and Boersma (1984) and Fritz and Krainer (2004). Based on fusulinids, the middle and upper parts are of Sakmarian age. Zircons from an ash layer near the top of the lower part yielded a U/Pb radiometric age of $296.46 \pm 0.11 \mathrm{Ma}$ (latest Asselian). The cycles coincide therefore with the maximum extent of the Gondwana glaciation in the Southern Hemisphere, which occurred during the Asselian-early Sakmarian, and are interpreted to be caused by glacio-eustatic sea-level fluctuations (Krainer, 2012).

\section{Zweikofel Formation}

This formation is represented by a cyclic sequence composed predominantly of dark gray, thin-bedded fossiliferous limestones and intercalated thin intervals of silt- and sandstones and finegrained, well-rounded and well-sorted quartz-rich conglomerates. Limestones contain abundant fossils, particularly calcareous algae (Homann, 1972), small foraminifers (Flügel, 1971b), fusulinids, corals, bryozoans, brachiopods, gastropods, bivalves and echinoderm fragments. Microfacies have been described by Flügel (1968), Buttersack and Boeckelmann (1984), and Sanders and Krainer (2005). Small algal mounds occur in the lower part (Forke, 1995; Samankassou, 2003). Cycles indicate repeated shifting from nearshore to offshore environments in an open marine shelf lagoon with normal water circulation (Flügel, 1981). Compared to the Schulterkofel and Grenzland formations, the limestones are characterized by more diverse fossil assemblages and microfacies types (Flügel, 1971a, 1981; Flügel et al., 1971).

According to Krainer and Schaffhauser (2012), the mixed siliciclastic-carbonate Zweikofel Formation at the type section (Zweikofel) and at Garnitzenbach is $94-106 \mathrm{~m}$ thick and consists of a cyclic succession of thin- to thick-bedded fossiliferous limestone and five intercalated, thin intervals of siltstone, sandstone and fine-grained, quartz-rich conglomerate. Fossils indicate deposition in a shallow-marine nearshore environment. The carbonate facies is characterized by moderate- to highenergy facies types (bioclastic, oolitic and oncolitic grainstone to packstone) and low- to moderateenergy facies types (bioclastic and oolitic 


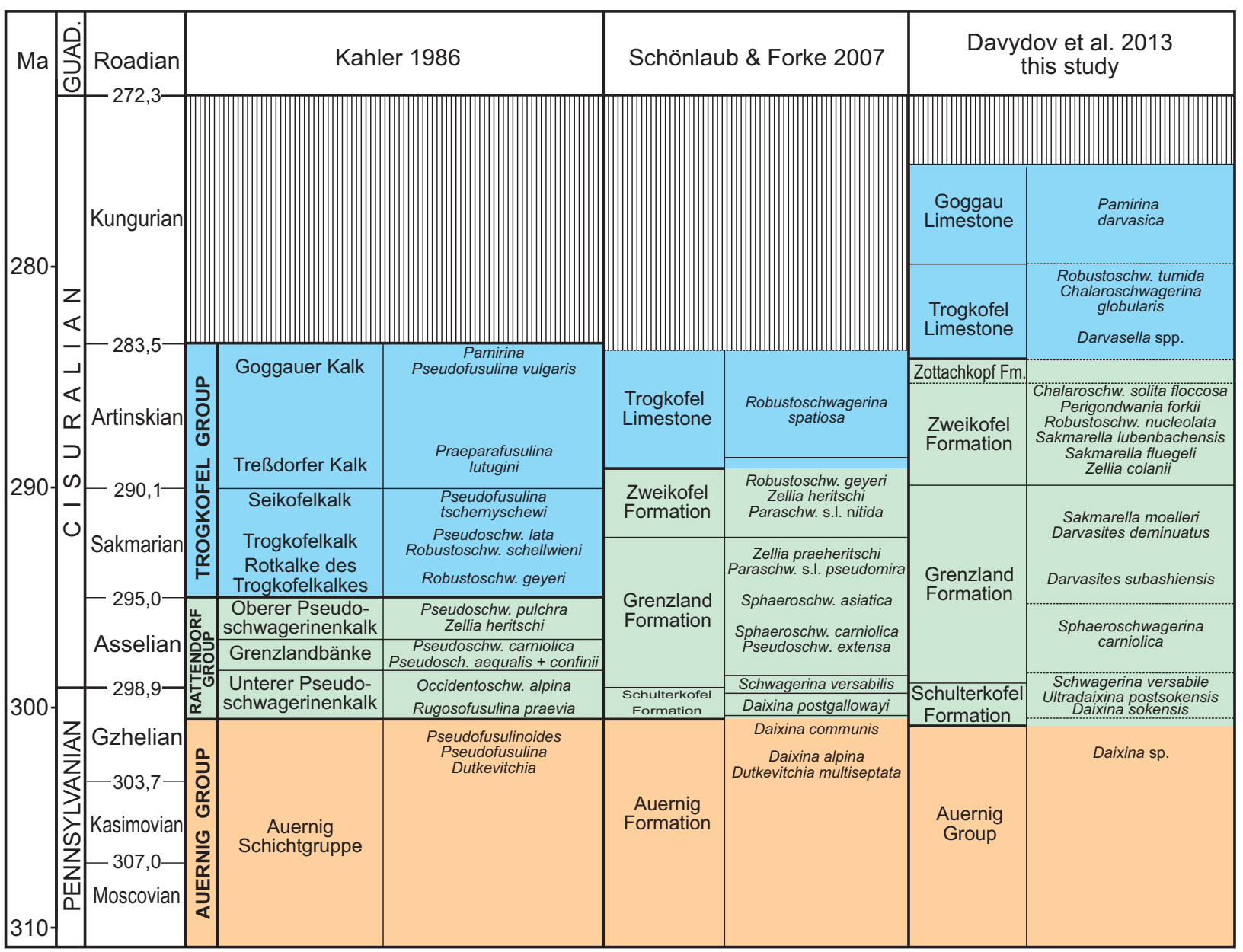

FIGURE 5. Pennsylvanian and Cisuralian series in the Carnic Alps.

wackestone to packstone, floatstone and rare cyanobacterial bindstone). A diverse faunal and algal assemblage indicates deposition in a shallow neritic, normal-salinity, low- to high-energy environment (Krainer and Schaffhauser, 2012).

The Zweikofel Formation is composed of six depositional sequences, which are interpreted as high-frequency cycles caused by glacio-eustatic sea-level fluctuations of the Gondwana glaciation (Krainer and Schaffhauser, 2012).

Within the Zweikofel Formation, five fusulinid assemblages are distinguished at Zweikofel, indicating approximately an Artinskian age, and the regional subdivisions, late Hermagorian to Yakhtashian (Krainer and Schaffhauser, 2012; Davydov et al., 2013).

\section{Zottachkopf Formation}

Detailed sedimentological studies of the Lower Permian succession at Zweikofel, Trogkofel and Zottachkopf showed that the bedded facies, which underlies the massive Trogkofel Limestone at Trogkofel and Zottachkopf differs significantly from the Zweikofel Formation at Zweikofel and Garnitzenbach (as defined by Krainer, 1995b).

The Zweikofel Formation with its type section at Zweikofel (Krainer, 1995b; Krainer and Schaffhauser, 2012) is a mixed siliciclastic-carbonate, cyclic succession of thin- to thick-bedded fossiliferous limestone and five intercalated thin intervals of siliciclastic sediments that allow a subdivision of the Zweikofel Formation into six depositional sequences. These depositional sequences can be further subdivided into parasequences, which are interpreted as high-frequency cycles caused by glacio-eustatic sea-level fluctuations of the Gondwana glaciation (Krainer and Schaffhauser, 2012).

This bedded facies is absent at Zweikofel where the boundary between the Zweikofel Formation and overlying Trogkofel Formation is a surface of erosion, documented by a truncation surface and locally by up to more than $15 \mathrm{~m}$ thick, coarse 
carbonate breccia composed of reworked limestone clasts displaying a facies similar to the Zweikofel Formation (Krainer et al., 2009). Obviously, the bedded facies (Zottachkopf Formation) has been eroded at Zweikofel.

The bedded facies, originally termed "Oberer Schwagerinenkalk" (Upper Schwagerina Limestone; Kahler and Kahler, 1937), is characterized by dark gray, thin bedded limestone containing abundant small oncoids. In the lower part siliciclastic sediments and reddish limestones rich in crinoid fragments occur. Locally, algal mounds are developed, particularly south of Zottachkopf. This bedded succession at Trogkofel and Zottachkopf was assigned to the "Upper Schwagerina Limestone" (= Zweikofel Formation) by Heritsch et al. (1934), Kahler and Kahler (1937), Flügel (1968, 1971a, 1975), Homann (1972) and Kahler (1986).

As this bedded facies is not an equivalent of the Zweikofel Formation, but is probably younger and differs in age and facies, Schaffhauser et al. (2010) proposed the term Zottachkopf Formation and included it in the Rattendorf Group.

The type section of the Zottachkopf Formation is located at the base of the steep northern slope of the Trogkofel (sections TNA-lower part, TNB-main part, and TNC-upper part). Reference sections are located on the southern and southwestern side of Trogkofel (TKS, TKW) where the upper part of the Zottachkopf Formation and basal part of the overlying Trogkofel Formation are well exposed. We also studied the Zottachkopf Formation at the sections Trogkar and Zottachkopf (Figure 2).

The Zottachkopf Formation is approximately $120 \mathrm{~m}$ thick and comprises thin- to medium-bedded fossiliferous limestones, reef mounds and a succession of red colored limestones with siliciclastic intervals. The carbonate facies is characterized by bioclastic pack/grain/rudstones and oncoidal floatstones, packstones to grainstones. Other common facies include fusulinid packstones, floatstones and echinoderm limestones. Fossils indicate deposition in a shallow marine environment. Compared to the sediments of the Zweikofel Formation, the deposits of the Zottachkopf Formation do not show this well-developed cyclicity, do not contain oolitic grainstones and algal floatstones, and contain only small-sized oncoids. The limestones are characterized by low terrigenous input in the lower part, display an algal assemblage that is dominated by phylloid algae (Neoanchicodium) and contain algal mounds up to several meters thick on the southern side of the Zottachkopf. Oncoidal floatstones, fusulinid float- stones and algal limestones indicate a shallow marine, low-energy environment on the southern side of the Trogkofel in contrast to stronger agitated conditions on the northern side and at Zottachkopf. A position closer to the shelf-edge is assumed. The Zottachkopf Formation is sharply overlain by the Trogkofel Limestone.

The upper part of the Zottachkopf Formation is exposed on the southern side of the Trogkofel massif and is composed of thin-bedded limestones (oncoidal floatstone, fusulinid floatstone, and bioclastic wackestone) with wavy bedding surfaces intercalated with algal mounds that consist of phylloid algal limestone and tubiphytid-algal boundstone. The section on the northern side of Trogkofel is characterized by alternating thin- to thick-bedded limestones, locally displaying poorly preserved cross-bedding. Five small, laterally arranged mounds with thin-bedded intermound facies are intercalated. Oncoidal floatstones are overlain by bioclastic packstones to grainstones and oncoidal packstones. The thickness of this succession reaches $90 \mathrm{~m}$ on the northern and about $40 \mathrm{~m}$ on the southern side of the Trogkofel massif. Locally, a few single rugose corals and small coral colonies are present in dark gray thinbedded limestone.

On the north-facing Trogkofel cliff, a well-bedded and red-colored succession of limestone and calcareous siltstone is exposed at the base of the Zottachkopf Formation (section TNA; Figure 2). The succession starts with reddish to gray limestone. Up-section two intervals of siliciclastic sediments (calcareous siltstone) are intercalated. Sedimentary features like small channel deposits, ripple cross-bedding, cross-bedding and horizontal lamination with interspersed quartz grains up to $2 \mathrm{~cm}$ in size are more common in the lower interval. These intervals are overlain by wavy to wellbedded limestone composed of bioclastic packstones to rudstones rich in echinoderms, fusulinids and/or oncoids. Thick-bedded limestone of oncoidal packstones and wackestones represent the top of this section. A fault separates this succession from the overlying Trogkofel Formation.

Preliminary biostratigraphic data from fusulinids of the north-facing Trogkofel cliff indicate a late Artinskian age for the Zottachkopf Formation.

Based on a detailed microfacies analysis, Flügel (1971a) interpreted the bedded limestone facies of the Zottachkopf section as deposits of a shallow marine environment with water depths of 10-20 m, normal salinity, mainly on hard bottoms formed by biodetritus and algal fragments 
cemented by encrusting foraminifers. He proposed a shelf lagoon of an inner shelf region without noticeable influence of coastal sedimentation as depositional setting.

Summing up, the facies of the Zottachkopf Formation is similar to the limestone facies of the Zweikofel Formation, although in detail some differences exist. The Zottachkopf Formation differs from the Zweikofel Formation in the following points: 1) the Zottachkopf Formation does not show the high-frequency cycles and the distinct siliciclastic horizons present in the Zweikofel Formation (Krainer and Schaffhauser, 2012); 2) fusulinids indicate a slightly younger age for the Zottachkopf Formation compared to the Zweikofel Formation; 3) in the Zweikofel massif, the Zweikofel Formation is erosively overlain by a coarse-grained limestone breccia indicating that the Zottachkopf Formation has been completely eroded there.

\section{Trogkofel Formation}

The Rattendorf Group is overlain by the dominantly massive Trogkofel Limestone, composed of Tubiphytes-Archaeolithoporella buildups that Flügel (1980, 1981) interpreted as shelf-edge carbonates.

Recently, Schaffhauser (2013) and Schaffhauser et al. (2015) studied the Trogkofel Formation at the type section. There, the Trogkofel Formation is up to $500 \mathrm{~m}$ thick and composed of massive to indistinctly bedded limestone. Locally, the limestone is dolomitized. At the base of this massif, bedded shelf limestones (Zottachkopf Formation) are sharply overlain by the dominantly massive Trogkofel Formation. Farther north, at the Zweikofel massif, the boundary between the Zweikofel Formation and the overlying, clino-bedded Trogkofel Formation is a disconformity. Deposition of the Trogkofel Formation started after a backstep from shelf deposition (Zottachkopf and Zweikofel formations) to a carbonate shelf-margin setting with buildups. The backstep was associated with synsedimentary tectonics.

The lower to middle part of the Trogkofel Formation at the type section is characterized by patch buildups that formed in a foreslope to upper slope setting. The main buildup facies include Tubiphytes-bryozoan-algal-cement boundstones, botryoidal-fibrous cementstones with Archaeolithoporella, and phylloid-algal bafflestones. The reef complex was capped by shelf margin sand shoal deposits and intertidal stromatolites. The build-ups alternate with bioclastic limestone intervals up to $10-15 \mathrm{~m}$ thick. The upper $\sim 100 \mathrm{~m}$ of the type section are composed primarily of bioclastic grainstones rich in fusulinids and fragments of calcareous green algae; the bioclastic grainstone intervals episodically aggraded at least to near sea-level. The upper part of the section probably resulted from a shoaling because of moderate progradation-aggradation of the platform, or because of eustatic or tectonic sea-level lowering and/or changed patterns of off bank sediment dispersal.

Syndepositional deformation, and the uplift that terminated deposition of the Trogkofel Formation, may be related to the "Saalian tectonic movements." The truncation surface that caps the Trogkofel Formation is onlapped by carbonatelithic breccias (Tarvis Breccia) (Schaffhauser et al., 2015). The nonmarine Tarvis Breccia is composed almost entirely of reworked Trogkofel limestone clasts, indicating that the upper part of the Trogkofel Formation was subaerially exposed and eroded.

\section{RATTENDORF GROUP AND TROGKOFEL FORMATION BIOSTRATIGRAPHY}

Kahler $(1980,1986)$ studied the fusulinids of the upper Paleozoic succession (including the Trogkofel Limestone) in the Carnic Alps over decades and proposed a biostratigraphic chart. For a long time, the stratigraphy in the Carnic Alps remained a lithostratigraphy, in groups and formations, due to the difficulties of the regional correlation with the Permian chronostratigraphy essentially established in the former USSR (Miklukho-Maklay, 1958; Leven, 1975). The Permian lithostratigraphy in the Carnic Alps includes the following formations in ascending order: Schulterkofel Fm, Grenzland Fm, Zweikofel Fm, Zottachkopf Fm, Trogkofel Fm, Goggau Fm, Tarvis Breccia, Val Gardena Fm, and Bellerophon Fm.

\section{Schulterkofel Formation}

Based on fusulinids, most of the Schulterkofel Formation is of latest Carboniferous age (Schwagerina robusta-Bosbytauella (= sic: Ultradaixina) bosbytauensis Zone), and the uppermost part (highstand systems tract of sequence 3 ) is dated as early Asselian due to the occurrence of "Schellwienia" bornemanni, "Zigarella" panjiensis and "Likharevites" inglorius (Krainer and Davydov, 1998), even if the validity of these three genera is currently under discussion (see also Kahler and Krainer, 1993; Davydov and Krainer, 1999; Forke, 2002). According to Schönlaub and Forke (2007), the Carboniferous/Permian (C/P) boundary probably lies within the uppermost limestone beds of the 
Schulterkofel Formation. They proposed to place the C/P boundary at the base of the Grenzland Formation.

\section{Grenzland Formation}

Limestones of the Grenzland Formation contain fusulinids indicating a middle-late Asselian age (Kahler, 1985, 1986; Forke, 1995; Krainer and Davydov, 1998). From the upper part of the Grenzland Formation, Forke (2002) described a fusulinid fauna containing Alpinoschwagerina (sic: Paraschwagerina) ex gr. nitida and early representatives of Zellia and Robustoschwagerina which indicate an early Sakmarian age (Schönlaub and Forke, 2007).

\section{Zweikofel Formation}

Forke (1995) dated the Zweikofel Formation as Sakmarian (Robustoschwagerina geyeri Zone and Zellia heritschi Zone). Conodonts indicate that the Zweikofel Formation extends into the early Artinskian (Schönlaub and Forke, 2007). The occurrence of some species of the conodont Neostreptognathodus and fusulinid Robustoschwagerina, in the basinal facies in the lower part of the Trogkofel Limestone induced Schönlaub and Forke (2007) to propose a late Artinskian age for the Trogkofel Limestone.

Kahler and subsequent workers included the Zottachkopf Formation in the "Upper Pseudoschwagerina Limestone," which was renamed by Krainer (1995b) as the Zweikofel Formation. According to Heritsch et al. (1934), the type section of the Upper Pseudoschwagerina Limestone is at Zottachkopf (section Zottachkopf of this study). Krainer (1995b) defined the section at Zweikofel as the type section of the Upper Pseudoschwagerina Limestone (Zweikofel Formation). The type section was studied in detail by Krainer et al. (2009) and Krainer and Schaffhauser (2012).

Kahler (1986) dated the "Upper Pseudoschwagerina Limestone" (Zweikofel Formation) as late Asselian based on the occurrence of Pseudoschwagerina pulchra and Zellia heritschi. Forke $(1994,2002)$ restudied the fusulinid and conodont fauna of the Zweikofel Formation which he dated as upper Sakmarian to Artinskian due to the occurrence of Robustoschwagerina geyeri, Zellia heritischi and Alpinoschwagerina (sic: Paraschwagerina) sensu lato nitida (Schönlaub and Forke, 2007).

The fusulinid fauna of the type section at Zweikofel was intensively studied by Davydov et al.
(2013) who determined five fusulinid zones, from bottom to top:

1) Sakmarella moelleri-Alpites (sic: Darvasites) deminuatis Zone;

2) Sakmarella fluegeli-Zellia colaniae (sic: colanii) Zone;

3) Sakmarella lubenbachensis-Robustoschwagerina nucleolata Zone;

4) Leeina pseudodivulgata-Chalaroschwagerina incomparabilis Zone; and

5) Chalaroschwagerina solita floccosa Zone.

Davydov et al. (2013) proposed the new regional Hermagorian stage as an equivalent of the entire Sakmarian and lower Artinskian of the Global Scale. Fusulinid Zone 1 which occurs in the basal $2 \mathrm{~m}$ of the Zweikofel Formation is similar to that of the underlying Grenzland Formation and is assigned to the Sakmarian. Fusulinid zones 2 and 3 indicate an age younger than Sakmarian but older than Yakhtashian. These fusulinid zones are assigned to the late Hermagorian. Fusulinid zones 4 and 5 correspond to the lower Yakhtashian. Therefore, the fusulinid fauna of the Zweikofel Formation at the type section indicates a late Hermagorian to early Yakhtashian age (approximately corresponding to the Artinskian) (Krainer and Schaffhauser, 2012; Davydov et al., 2013).

\section{Zottachkopf Formation and Trogkofel Formation}

According to Kahler $(1980,1986)$, the Rotkalke des Trogkofels, Trogkofelkalk and Seikofelkalk are Sakmarian in age, whereas the Treßdorfer Kalk and Goggauer Kalk are Artinskian, and the Tarviser Breccie is of "Cisjanskian" age. The biostratigraphic age of the Trogkofelkalk is mainly based on fusulinids from Forni Avoltri, as, according to Kahler (1980), the Trogkofel Limestone at the type locality contains only few fusulinids that are not determinable due to dolomitization.

Forke (1995) noted the problem of dating the Trogkofel Limestone as hitherto no fusulinid fauna has been described from the Trogkofel Limestone at Trogkofel; in his discussion he refers to the fusulinids of the Trogkofelkalk of Forni Avoltri. Further confusion produced the misinterpretation of the stratigraphic position of the fusulinid-bearing Red Limestone (Rotkalk der Höhe 2004). The red limestones from locality "Höhe 2004" yielded a fusulinid fauna including Robustoschwagerina geyeri, first recognized as a "Pseudoschwagerina" by Kahler and Kahler (1938), indicating a younger age than that of the Upper Pseudoschwagerina Limestone. Kahler (1983a, 1986, 1992) dated these red 
limestones as Sakmarian and therefore ascribed them to the Trogkofel Limestone. Forke (1995) placed the red limestone into the Upper Pseudoschwagerina Limestone (= Zweikofel Formation), and dated the entire Zweikofel Formation as Sakmarian. Schönlaub and Forke (2007) dated the Zweikofel Formation as late Sakmarian to early Artinskian.

Detailed field studies at Zweikofel, Trogkofel and Zottachkopf showed that the red limestone and associated bedded facies that underlies the massive Trogkofel Limestone at Trogkofel and Zottachkopf differs significantly from the Zweikofel Formation at Zweikofel and Garnitzenbach. Outcrops at the base of the steep cliff at the northern side of Trogkofel showed that these red limestones occur near the base of a succession composed mainly of thin-bedded limestone approximately 120 $m$ thick. For this succession which differs from the Zweikofel Formation, Schaffhauser et al. (2010) proposed the term Zottachkopf Formation (see Krainer and Schaffhauser, 2012). Davydov et al. (2013) studied the fusulinid fauna of this red limestone of Höhe 2004. The fauna includes fusulinids that are characteristic of the fusulinid Zone 5 at the top of the Zweikofel Formation (Artinskian). Additionally, the assemblage contains abundant Darvasella, including $D$. praecox Leven in Leven, Leonova and Dmitriev, 1992, and Laxifusulina, as well as advanced Robustoschwagerina species, which in Darvas are characteristic of the upper Yakhtashian and Bolorian and thus pointing to a slightly younger age compared to the Zweikofel Formation (Davydov et al., 2013).

The basal Trogkofel Limestone at Trogkar contains fusulinids that are typical of the upper Yakhtashian in Darvaz (Davydov et al., 2013), including Quasifusulina magnifica Leven in Leven, Leonova and Dmitriev, 1992, Chalaroschwagerina globularis Skinner and Wilde, 1966, Robustoschwagerina tumida (Likharev, 1939), Perigondwania? sera (Leven in Leven, Leonova and Dmitriev, 1992), P.? oingaronica (Leven in Leven, Leonova and Dmitriev, 1992), and Praeskinnerella pseudogruperaensis Leven in Leven, Leonova and Dmitriev, 1992. According to Davydov et al. (2013), the Trogkofel Limestone is of late Artinskian to early Kungurian (upper Yakhtashian) age, but it should be considered that fusulinids from the middle and upper part of the Trogkofel Limestone have not yet been studied.

Summing up, fusulinids of the red limestone at the base of the Zottachkopf Formation indicate a slightly younger age (late Artinskian) than the
Zweikofel Formation. The overlying lower part of the Trogkofel Formation is dated as late Artinskian to early Kungurian.

\section{SYSTEMATIC PALEONTOLOGY}

$$
\text { (by D. Vachard) }
$$

The studied groups are: Cyanobacteria, Rhodophyta, Bryopsidales (including phylloid algae and gymnocodiaceans), Dasycladales and Algospongia (Figure 6). Their supposed phylogenies, based on numerous observations of the algal and pseudoalgal Paleozoic groups are summarized here in four figures (Figures 7-10). The taxa mentioned in this study are listed in a table (Table 1). Taxonomic descriptions and systematics follow the schemes of algal taxonomy proposed by Bassoullet et al. (1979), Bucur (1994), Granier and Grgasović (2000), and Vachard and Cózar (2010). The material is housed at Innsbruck University, Austria (collection numbers GB1-175, GBT1-11, TK 1-70, TKS1-19, TKW1-18, TM1-9, TNA1-30, TNB123, TNC1-11, Z1-19, ZK1-215, ZKO1-47 and ZT1-18).

\section{Figures 9-30}

Abbreviations: Throughout the text, we used the following abbreviations: $L=$ length; $D=$ outer diameter; $d=$ inner diameter; $s=$ thickness of thallus; $p$ $=$ diameter of pores $(=$ diameter of laterals, siphons, or utricules); and ip = distance between two pores (i.e., between two laterals, two siphons, or two utricles).

\section{Phylum CYANOBACTERIA (ex Stanier, 1974) Cavalier-Smith, 2002}

Description. Microbial structures represented by isolated, coccoid or tubular filaments (eventually with pseudoramifications, or true bifurcations), bioconstructions of types of stromatolite, oncoids, microbialites or dendrolites, or nodular colonies composed of single to bifurcated spans of filaments. Wall dark microgranular; rarely recrystallized.

Remarks. Cyanobacteria (or cyanoprokaryotes, or formerly blue-green algae, cyanophyceae, myxophyceae and calcimicrobes) were always particularly hard to be classified, and recently the whole classification was restructured and revised based on molecular sequence data (Komárek et al., 2014). Due to the possible morphological complexity of the cyanobacteria from coccoid individuals to hemispherical colonies of bifurcated filaments, we speculate here that a possible phylogeny at the ordinal hierarchical levels are represented (Figure 


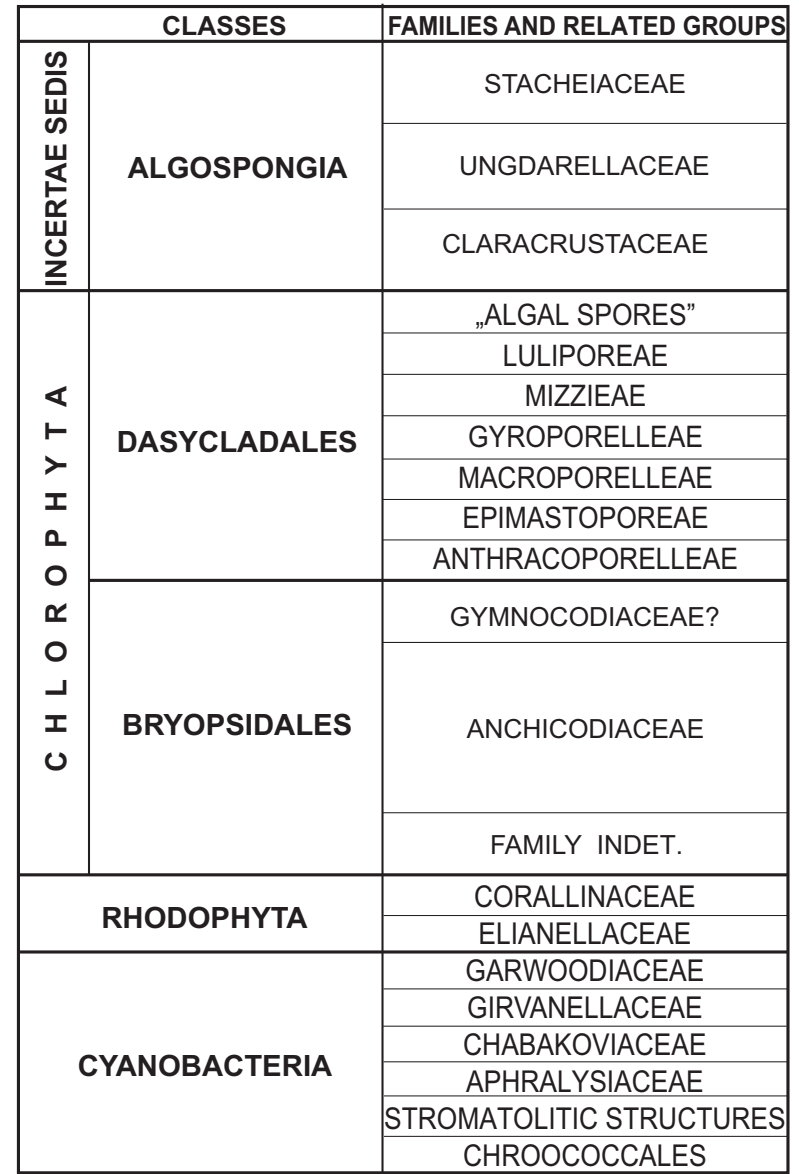

FIGURE 6. Algal classification adopted here.

9) by 1) coccoid thalli (incerti ordinis 1; probably Chroococcales Geitler, 1925); 2) filamentous and/ or coccoid, stromatolitic and microbialitic taxa (incerti ordinis 2: stromatolites sensu lato); 3 ) carbonate stromatolitic textures (incerti ordinis 3; family Aphralysiaceae Vachard in Vachard, Hauser, Martini, Zaninetti, Matter and Peters, 2001a); 4) colonial coccoid? textures (incerti ordinis 4; family Chabakoviaceae Kordé, 1973); 5) tubular, single filaments (?order Proauloporales Luchinina, 1975 or Oscillatoriales Elenkin, 1934; family Girvanellaceae Luchinina, 1975); 6) colonial groups of filaments (?order Proauloporales or Oscillatoriales; family Garwoodiaceae Shuysky, 1973).

Class CYANOPHYCEAE Sachs, 1874

Order ?CHROOCOCCALES Geitler, 1925

Genus NOSTOCITES Maslov, 1929

Type Species. Nostocites vesiculosa Maslov, 1929 , by subsequent designation by Maslov, $1956 \mathrm{~b}$.

Description. Flattened thallus composed of a sheet of loosely packed, globular or dolioliform cells; one cell-thick; each cell emplacement is

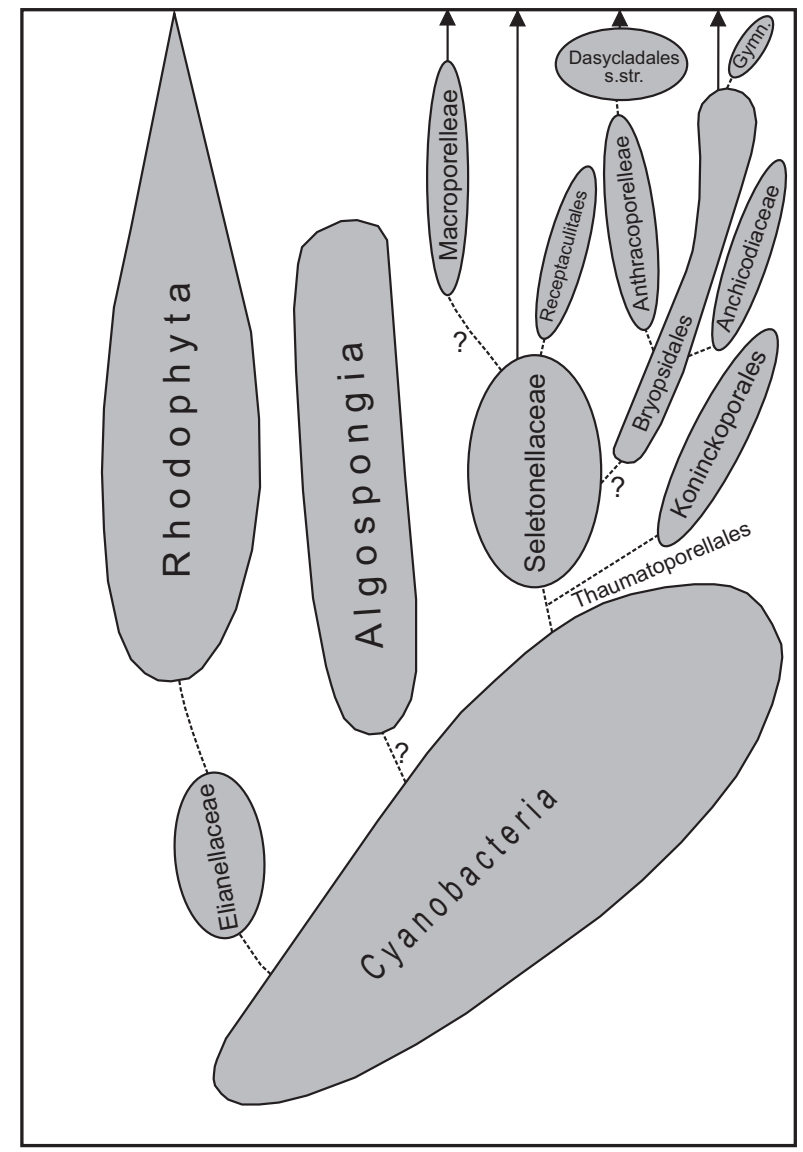

FIGURE 7. Hypothetical algal phylogeny proposed in this paper, mainly at the level of the classes.

entirely recrystallized in yellowish, hyaline calcite often with a dark inclusion in its center.

Remarks. Nostocites is an easily identifiable taxon, despite its disputable botanical assignment (Maslov, 1929; Pia, 1937; Vachard et al., 2001a). An assignment to the globochaetaceans (Vachard, 1980; Vachard and Beckary, 1991; Perret et al., 1994; Skompski, 1996; Vachard et al., 2001a; Mamet, 2006) and/or other groups of the marine bacterioplankton seems to be most logical.

Occurrence. Early Viséan-late Capitanian (Vachard et al., 2001a); probably cosmopolitan.

Nostocites vesiculosa Maslov, 1929

Figure 11.1-2

*1929 Nostocites vesiculosa Maslov, p. 1538, textfigs. $1-3,7$, pl. 70, figs. 2, 7, 9-10.

1937 Nostocites vesiculosa; Pia, p. 807-808 (no illustration).

1963 Nostocites vesiculosa; Maslov et al. in Orlov, p. 46, fig. 29.

vp. 1977a Globochaete sp.; Vachard, p. 374, table 1 (part.: only the late Viséan specimens; no illustration). 


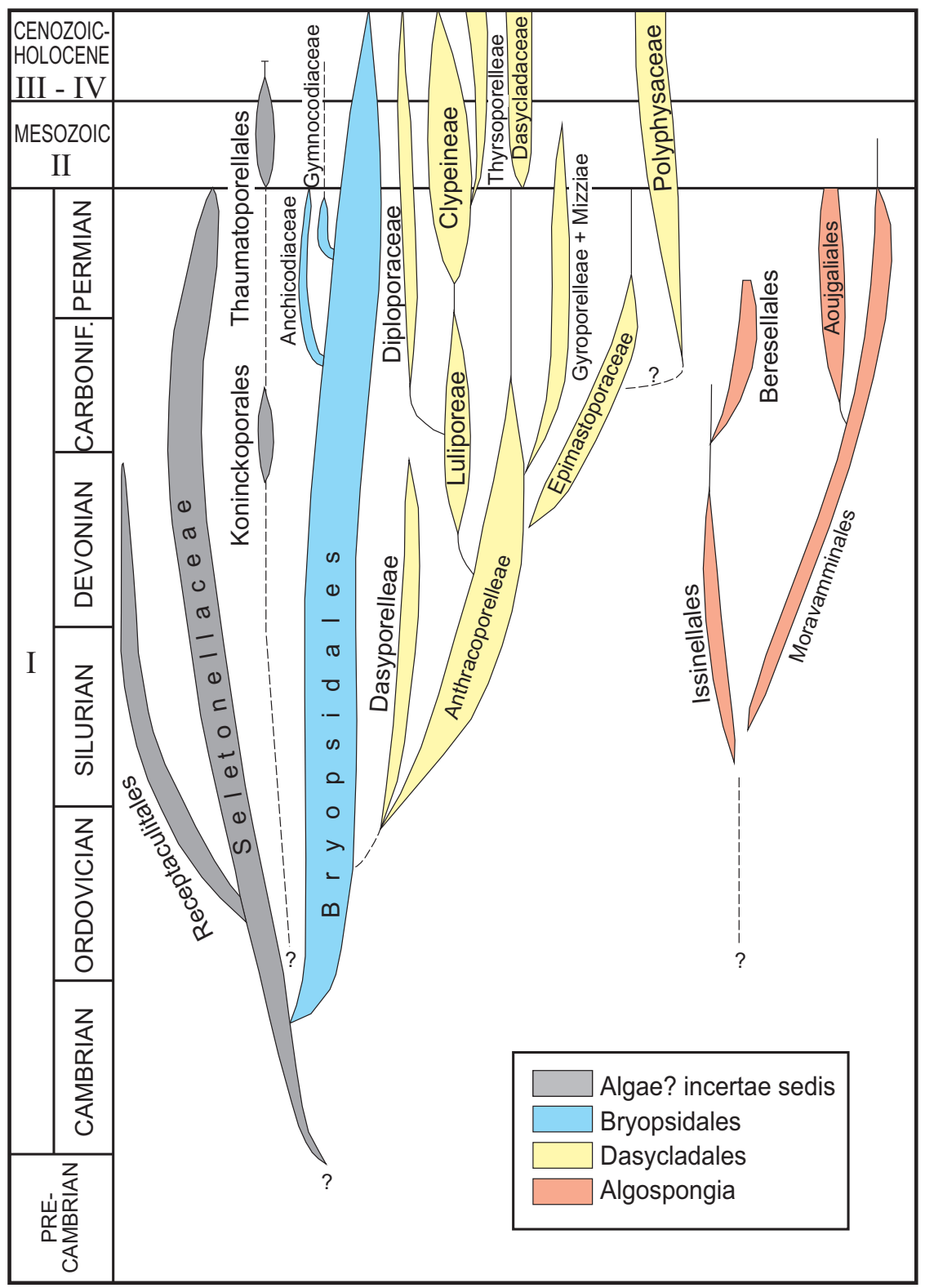

FIGURE 8. Hypothetical algal phylogeny, mainly at the level of orders and families.

1978 Litostroma sp.; Jansa et al., p. 1436, pl. 1, 1985 figs. 10, 11.

$1978 \quad$ Nostocites vesiculosa; Mamet and Roux, p. 80 , pl. 6 , fig. 2 only (non figs. $1,3=$ ornamented ostracods) (with three references in synonymy).

1981 Nostocites vesiculosa; Mamet and Martínez, pl. 3, fig. 8.

1983 Nostocites cf. N. vesiculosa; Groves, p. 3132, pl. 7, figs. 7, 10-12 (with synonymy).

p. 1983 Nostocites vesiculosa; Mamet and Roux, p. 98, pl. 10, figs. 9-11 (non figs. 12, $13=$ ostracods) (with synonymy).
Nostocites vesiculosa; Mamet and Pinard, pl. 1, fig. 19.

$1986 \quad$ Nostocites sp.; Groves, p. 490, figs. 8, 9.

? 1987 Nostocites vesiculosa; Mamet et al., p. 58, pl. 30, figs. 1, 2 (with synonymy).

v. 1990 Nostocites vesiculosa; Vachard, p. 94 (no illustration).

v. 1991 Nostocites ex gr. vesiculosa; Vachard and Beckary, p. 322_323, pl. 2, fig. 10 (with synonymy).

v. 1991 Nostocites vesiculosa; Vachard et al., p. 677, pl. 1, fig. 7.

1992 Nostocites vesiculosa; Mamet and Préat, p. 60 , pl. 1, fig. 6 . 
KRAINER, VACHARD, \& SchafFHAUSER: YAKHTASHIAN ALGAE, CARNIC AlPS

TABLE 1. List of the algal main groups and their species and taxa described in this paper.

\begin{tabular}{|c|c|c|}
\hline Algal main groups & Species or taxa & Illustrations in this study \\
\hline & Efluegelia ex gr. johnsoni (Flügel 1966) & $\begin{array}{l}\text { Figure } 27.10-27.12 \text {, Figure } 29.1-29.9,29.12 \text {, Figure } \\
30.1,30.2,30.5,30.8-30.11\end{array}$ \\
\hline & $\begin{array}{l}\text { Efluegelia johnsoni (Flügel, 1966) emend. Vachard } \\
\text { in Massa and Vachard, } 1979\end{array}$ & Figure $29.10,29.11$, Figure $30.3,30.4,30.6,30.7$ \\
\hline \multirow[t]{13}{*}{ ALGOSPONGIA } & $\begin{array}{l}\text { Ungdarella uralica Maslov, 1956a non 1956b nec } \\
1950\end{array}$ & Figure 27.13 - 27.15, Figure $28.1-28.9$ \\
\hline & $\begin{array}{l}\text { Claracrusta catenoides (Homann, 1972) emend. } \\
\text { Vachard in Vachard and Montenat, 1981 }\end{array}$ & Figure 20.1, Figure 26.5 - 26.8 \\
\hline & "Algen-Sporen" (algal spores) & $\begin{array}{l}\text { Figure } 21.7,21.9,21.11, \text { Figure } 22.11,22.12, \text { Figure } \\
23.16, \text { Figure } 24.3, \text { Figure } 25.3,25.4,25.10, \text { Figure } \\
27.13-27.15, \text { Figure } 28.8,28.9, \text { Figure } 30.11\end{array}$ \\
\hline & Salopekiella? sp. & Figure 27.5 \\
\hline & Connexia slovenica Kochansky-Devidé, 1979 & Figure 26.1 - 26.4, Figure 27.9 \\
\hline & Mizzia cornuta Kochansky-Devidé and Herak, 1960 & $\begin{array}{l}\text { Figure 22.7, 22.8, Figure 23.3, 23.5, 23.6, 23.8, 23.13, } \\
23.18\end{array}$ \\
\hline & Mizzia yabei (Karpinsky, 1909) emend. Pia, 1920 & $\begin{array}{l}\text { Figure 22.12?, 22.13?, Figure 23.4, } 23.15-23.17, \\
\text { Figure 25.1, 25.2, 25.5, 25.7, 25.8, } 25.9 \text { (bottom), } 25.10\end{array}$ \\
\hline & Mizzia velebitana Schubert, 1908 & $\begin{array}{l}\text { Figure } 22.9-22.11, \text { Figure } 23.7,23.9-23.12,23.14 ? \\
\text { Figure } 25.3,25.4,25.5,25.9 \text { (top), } 25.11-25.13,25.14 ?\end{array}$ \\
\hline & $\begin{array}{l}\text { Pseudoepimastopora carnica (Flügel, } 1966 \mathrm{n} \text {. } \\
\text { comb., emend herein) }\end{array}$ & Figure 25.1 - 25.12, Figure 27.3, 27.6 \\
\hline & Gyroporella sp. & Figure $25.9 ?$, Figure 27.1 \\
\hline & Macroporella cf. siamensis Endo, 1969 & Figure 23.1, 23.2 \\
\hline & Globuliferoporella? sp. & Figure 25.13 \\
\hline & Globuliferoporella angulata Chuvashov, 1974 & Figure 21.2 - 21.5, 21.6? \\
\hline \multirow[t]{13}{*}{ DASYCLADALES } & Globuliferoporella piai (Kordé, 1951) n. comb. & $\begin{array}{l}\text { Figure 19.12, 19.13, 19.15, Figure 21.1, 21.7?, } 21.8 \text { - } \\
21.11\end{array}$ \\
\hline & Epiastopora fluegeli (Kulik, 1978) n. gen. n. comb. & Figure 19.10 \\
\hline & $\begin{array}{l}\text { Epiastopora alpina (Kochansky-Devidé and Herak, } \\
\text { 1960) n. gen. n. comb. }\end{array}$ & $\begin{array}{l}\text { Figure } 19.5,19.10, \text { Figure 20.5, Figure 21.8, Figure } \\
22.2,22.5\end{array}$ \\
\hline & Epimastopora cf. izawaikensis Endo, 1953a & Figure 19.14, Figure 20.6 \\
\hline & $\begin{array}{l}\text { Epimastopora likana Kochansky-Devidé and Herak, } \\
1960 \text { emend. herein }\end{array}$ & $\begin{array}{l}\text { Figure } 18.8,18.10,18.11, \text { Figure } 19.3 .19 .4,19.12 \\
\text { (bottom, center), Figure 20.3, Figure } 22.3,22.6 ?, \text { Figure } \\
27.2 \text { ?, } 27.5\end{array}$ \\
\hline & $\begin{array}{l}\text { Epimastopora japonica Endo, } 1951 \text { emend Mamet, } \\
\text { Roux and Nassichuk, } 1987\end{array}$ & $\begin{array}{l}\text { Figure 18.6, 18.7, 18.9, Figure 19.1, 19.2, } 19.6 \text { - 19.9, } \\
19.12 \text { (left) }\end{array}$ \\
\hline & $\begin{array}{l}\text { Paraepimastopora kanumai (Endo in Endo and } \\
\text { Kanuma, 1954) }\end{array}$ & Figure $18.4,18.5 ?$ \\
\hline & $\begin{array}{l}\text { Anthracoporella vicina Kochansky-Devidé and } \\
\text { Herak, } 1960\end{array}$ & Figure 18.2, 18.3, Figure 20.2 \\
\hline & $\begin{array}{l}\text { Anthracoporella spectabilis Pia, } 1920 \text { emend De } \\
\text { Castro, } 2002\end{array}$ & Figure 18.1, Figure 22.1 \\
\hline & Nanjinophycus? sp. & Figure 17.7, Figure 22.4? \\
\hline & Calcipatera schoenlaubi n. sp. & Figure $17.5,17.6,17.8$ - 17.11, Figure 20.1 \\
\hline & $\begin{array}{l}\text { Neoanchicodium catenoides (Endo in Endo and } \\
\text { Kanuma, 1954) }\end{array}$ & Figure 16.4 - 16.9, Figure 17.7, 17.8, Figure 18.6 \\
\hline & Eugonophyllum? konishi Kulik, 1978 & Figure $17.1,17.2$ \\
\hline BRYOPSIDALES & Eugonophyllum magnum (Endo, 1951) & Figure 11.4 , Figure $14.11,14.12$, Figure 15.1 - 15.12, \\
\hline
\end{tabular}


TABLE 1 (continued).

\begin{tabular}{lll}
\hline Algal main groups & \multicolumn{1}{c}{ Species or taxa } & \multicolumn{1}{c}{ Illustrations in this study } \\
\hline & emend. Konishi and Wray, 1961 & Figure 16.1 - 16.3, 16.10 - 16.13, Figure 17.3 - 17.4 \\
& Ivanovia tenuissima Khvorova, 1946 & Figure 20.4, Figure 26.16, Figure 29.9, Figure 30.11 \\
& Anchicodium japonicum Endo, 1953a & Figure 14.6 - 14.8 \\
& Homannisiphon morikawai (Endo, 1954) & Figure 14.9, 14.10 \\
& Archaeolithophyllum lamellosum Wray, 1964 & Figure 13.6 - 13.16, Figure 14.1 - 14.5 \\
RED ALGAE & Parachaetetes ortonelloides (Endo, 1961c) n. comb. Figure 13.1, 13.3 - 13.5 \\
& Garwoodia sp. & Figure 12.5 \\
& Clinortonella cf. goggauensis (Flügel and Flügel- & Figure 12.2, 12.12? \\
& Kahler, 1980) & \\
& Koivaella ex gr. permiensis Chuvashov, 1974 & Figure 12.3, 12.4, 12.6 - 12.10 \\
& Mitcheldeania sp. & Figure 11.5 \\
& Girvanella sp. & Figure 11.4 \\
& Gahkumella sp. & Figure 11.3 \\
& Renalcis cf. granosus Vologdin, 1932 & Figure 12.1, Figure 27.4 \\
& Archaeolithoporella hidensis Endo, 1961a & Figure 11.7 - 11.10, Figure 12.11 \\
Stromatolites indet. & Figure 11.6 \\
Nostocites vesiculosa Maslov, 1929 & Figure 11.1, 11.2 \\
\hline CYANOBACTERIA &
\end{tabular}

non 1996 Nostocites vesiculosa; Sebbar and Mamet, text-fig. 5.31, pl. 3, fig. 3 (= hinge of ostracod).

v. 1996 Nostocites vesiculosa; Vachard and Maslo, text-fig. 2 p. 361.

1996 Globochaetes (sic); Jones and Somerville, fig. $4 \mathrm{~h}$.

1996 Globochaete alpina (Lombard); Skompski, pl. 16, fig. 4.

?1999 Nostocites vesicula (sic); Sebbar and Mamet, text-fig. 3.53 (no illustration).

$2000 \quad$ Nostocites vesiculosa (= Globochaete auct.); Mamet and Stemmerik, fig. 9G.

v.2001a Nostocites sp.; Vachard and Krainer, p. 151 (no illustration).

v2001a Nostocites vesiculosa; Vachard in Vachard et al., p. 390 , 392-393, text-fig. 6 p. 379, fig. 18.1 (with seven references in synonymy).

v2003a Nostocites vesiculosa; Krainer et al., p. 18, 19, table 1 p. 18, pl. 3, fig. 13, pl. 5, fig. 3.

$2003 \quad$ Nostocites vesiculosa; Khodjanyazova and Mamet, pl. 5, fig. 14.

?2004 Nostocites vesiculosa; Cózar, text-fig. 3 p. 371, text-fig. 4 p. 372 (no illustration).

?2004 Nostocites vesiculosa; Cózar and Somerville, text-fig. 3, text-fig. 9 (no illustration). v.2005 Nostocites vesiculosus (sic); Saïd, p. 178, fig. X.1.12.

2006 Nostocites vesiculosa; Mamet, p. 346, 348, pl. 7, figs. 20-23 (with 25 references in synonymy, even if many of them rather concern Globochaete).

$2007 \quad$ Nostocites vesiculosa; Cózar et al., text-fig. 3 p. 101.

v2008 Nostocites vesiculosa; Pille, p. 55-56, pl. 17, fig. 6.

$2010 \quad$ Nostocites vesiculosa; Mamet and Préat, p. 32 , pl. 9, figs. 7, 8 .

v2014 Nostocites vesiculosa; Vachard et al., fig. S3(12).

Description. Only two sections were measured: thallus diameter $=250-500 \mu \mathrm{m}$; cell diameter $=$ 30-50 $\mu \mathrm{m}$; central inclusion diameter $=7$ (rarely 10) $\mu \mathrm{m}$.

Remarks. Nostocites vesiculosa is generally the unique species of the genus (Mamet and Roux, 1978); some other specific taxa remain in open nomenclature (Vachard and Krainer, 2001a). Some atypical recrystallizations of dolomite rhomboedra can be confused with Nostocites (for example, Nostocites? of Krainer et al., 2017b, figure 27H), as well as, and more paradoxically, some hinges of 


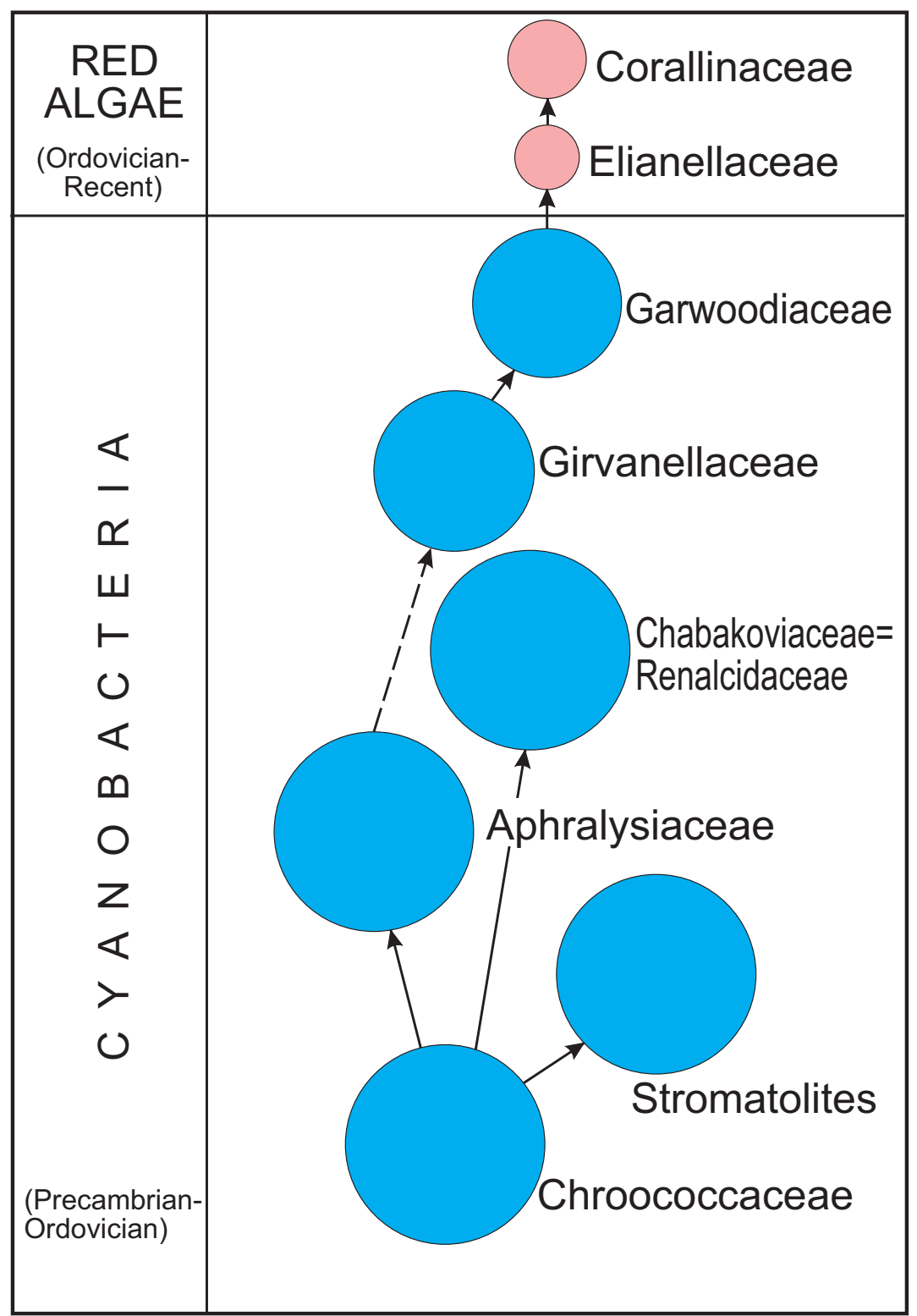

FIGURE 9. Possible phylogeny of cyanobacterial groups mentioned in this study.

ostracods (Mamet and Roux, 1978, 1983; Mamet et al., 1987; Sebbar and Mamet, 1996; as indicated by Krainer et al., 2003a, plate 6, figure 8 ).

Occurrence. Early Viséan-late Capitanian (Vachard et al., 2001a); probably cosmopolitan. In the Carnic Alps: Auernig Fm (Vachard and Krainer, 2001a). This study: Zweikofel Fm (sample ZK203_3) and Trogkofel Fm (sample TK26_3).

Incerti ordinis

Stromatolites indet.

Figure 11.6

1968 Stromatolithen Typ LLH-S/LL-H-C; Flügel, p. 56 (no illustration).
1968 Stromatolithen Typ SS-C/LLH-C; Flügel, p. 56 (no illustration).

Description. This term is used here for designating microbialites with a laminar, plane, distinct stratification, with entirely calcareous material.

Remarks. Within the Trogkofel Formation, crudely laminated bindstones composed of cyanobacteria, probably Girvanella and other micritic-walled tubes form stromatolites up to $10 \mathrm{~cm}$ thick, which may be termed skeletal stromatolites according to Riding (1991) (Schaffhauser, 2013; Schaffhauser et al., 2015). In reef cavities millimeter-sized laminated sediments occur, which are composed of peloidal grainstone laminae and cement crusts (Schaffhauser, 2013). These crusts may be termed hybrid 


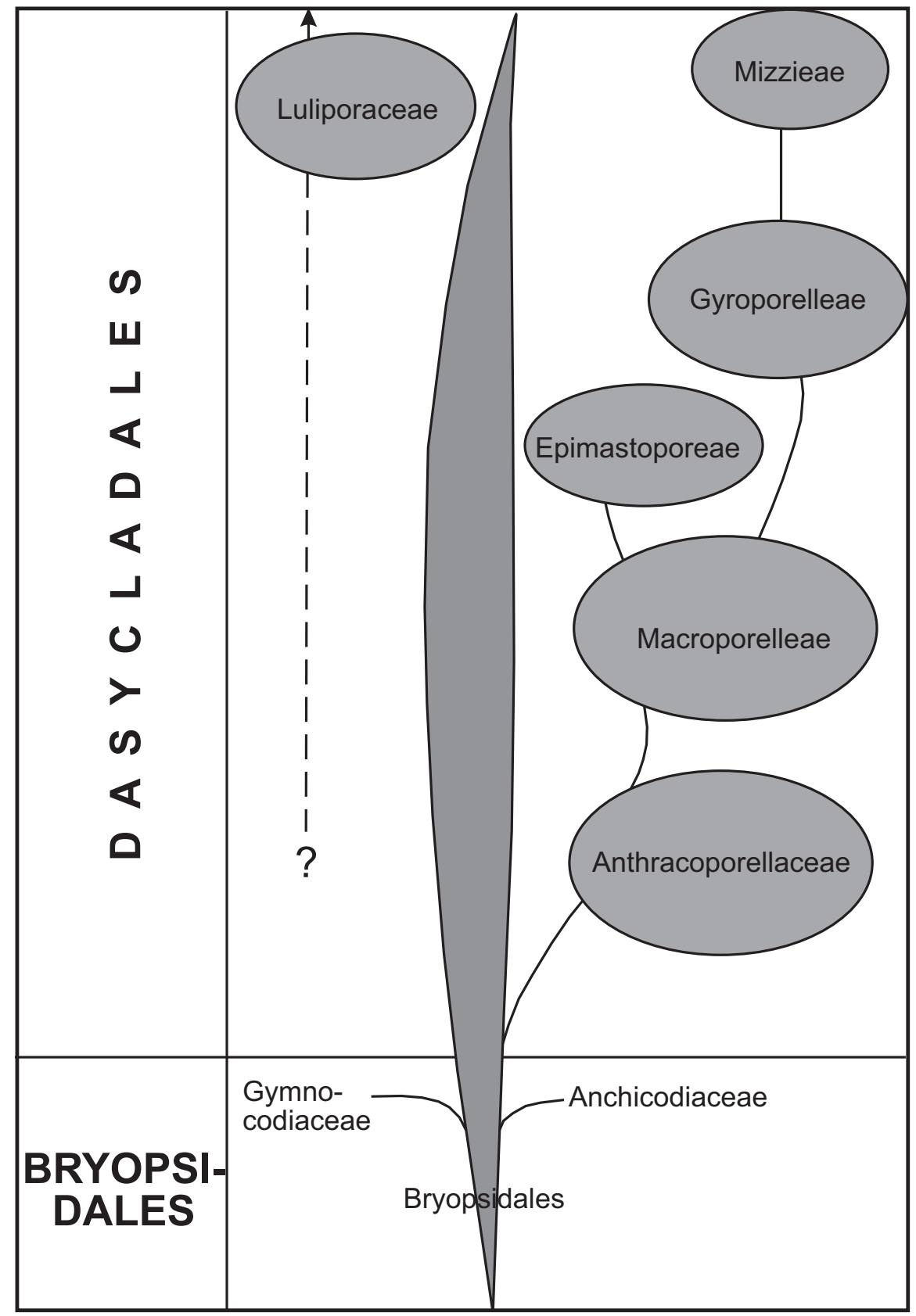

FIGURE 10. Another possible phylogeny of the Bryopsidales and Dasycladales mentioned in this study, mainly at the level of families and tribes.

crusts according to Riding (2008). In the reef cavities the laminites are associated with reef cements and micropeloidal pack- and wackestone (Schaffhauser, 2013). Stromatolites are not known from the Zweikofel and Zottachkopf formations, but they are relatively common in the Trogkofel Fm (Flügel, 1968).

Occurrence. In our material of the Carnic Alps, only one specimen (sample TKW2_1) was studied from the Zottachkopf Fm.
Incerti ordinis

Family APHRALYSIACEAE Vachard

in Vachard, Hauser, Martini, Zaninetti, Matter and Peters, 2001a

Genus ARCHAEOLITHOPORELLA Endo, 1961a

Type species. Archaeolithoporella hidensis Endo, 1961a, by original designation.

Description. Large flattened crusts or oncoids (tebagites) constituted by laminar layers alternatively dark and clear, interpretable as superposed 

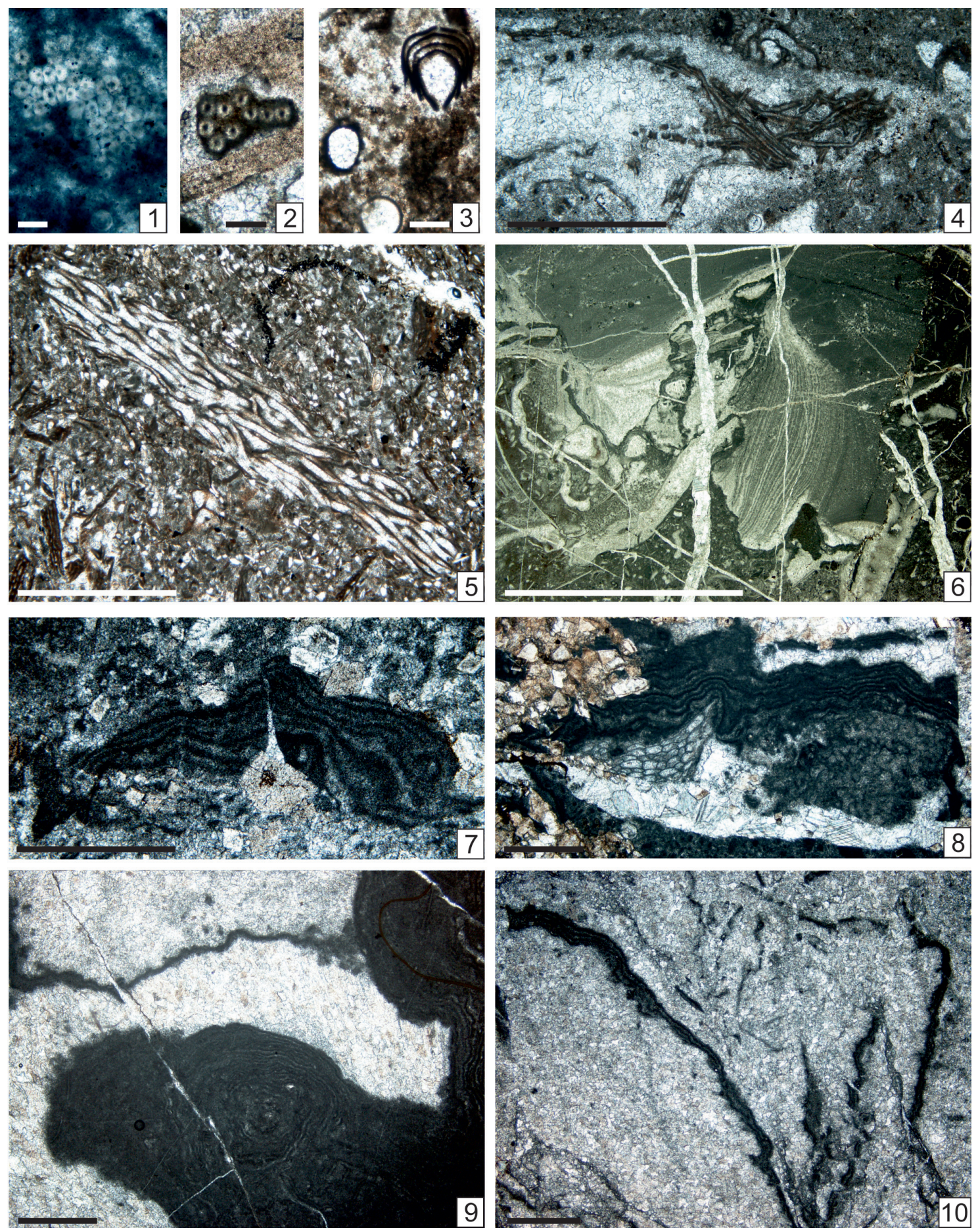

FIGURE 11. 1, 2. Nostocites vesiculosa Maslov, 1929. 1. Random section. Sample TK26_3/00011. 2. Random section. Sample ZK203_3. 3. Gahkumella sp. Two transverse sections (bottom, left) and an axial section (top, right). Sample GB 157_13. 4. Girvanella sp. Longitudinal and transverse sections perhaps boring an Eugonophyllum magnum (Endo, 1951) emend. Konishi and Wray, 1961 encrusted by a tuberitinid (bottom) and palaeonubeculariid (top). Sample GB35_4. 5. Mitcheldeania sp. Longitudinal section showing the large filaments and their bifurcations. Sample GB17_2b. 6. Stromatolite. Axial sections. Sample TKW2_1. 7-10. Archaeolithoporella hidensis Endo, 1961a. 7. Longitudinal section attached on a tubiphytid. Sample GBT4_1. 8. Longitudinal section attached on tubiphytid and a bryozoa. Sample GBT11_2. 9. Large colony, in transverse section, subrounded by botryoidal cement. Sample TK68_1. 10. Thin colonies encrusting large botryoidal cement. Sample TK60_AP. Scale bars: $0.1 \mu \mathrm{m}$ (Figures 11.1-11.3) and $1 \mu \mathrm{m}$ (Figures 11.4-11.10). 
sheets of cylindrical trichomes without pseudoramifications forming stromatolitic structures. Wall dark microgranular.

Occurrence. Rare in Asselian-Sakmarian of the Urals; Artinskian-Changhsingian, cosmopolitan.

Archaeolithoporella hidensis Endo, 1961a Figure 11.7-10, Figure 12.11

*1961a Archaeolithoporella hidensis Endo, p. 182, pl. 39, figs. 3-5.

1961b Archaeolithoporella hidensis; Endo, p. 41, pl. 16, fig. 4.

1961c Archaeolithoporella hidensis; Endo, p. 84, pl. 2, figs. 1, 2.

1963 Archaeolithoporella hidensis; Johnson, p. 98 pl. 48, fig. 1 (not 2, as indicated in the text).

1964 Algues encroûtantes; Glintzboeckel and Rabaté, pl. 59, figs. 1, 2, pl. 105, figs. 1, 2.

1966 Stromatolithen-Typ LLH-S/LLH-C; Flügel, p. 52-53, pl. 9, figs. 2, 3.

.1970a Stromatoliti/Stromatolithen; Kochansky-Devidé, p. 210, 238, pl. 20, figs. 1, 2.

1972 Stromatolithen-Typus LLH-C/LLH-C; Homann, p. 250-251, pl. 9, fig. 67.

1975 an irregular lamina of possible algal origin; Wilson, pl. 25, fig. B.

1976 Archaeolithoporella hidensis; Emberger $\mathrm{p}$. 100 (no illustration) (with three references in synonymy).

1977 Stromatolites-lined cavities; Flügel, p. 325, pl. 2, fig. 3.

.1977 A. hidensis (sic); Lemoine, p. 1322 (no illustration).

.1979 Archaeolithoporella laminae; Babcock, pl. 1, fig. 6.

.1979

1979

Archaeolithoporella sp.; Flügel, p. 572, pl. 1, fig. 3.

Stromatolithes; Nguyen Duc Tien, pl. 27, figs. 8, 9.

1980 Archaeolithoporella hidensis; Flügel, pl. 13, figs. 2, 4, 6, 7.

1980 Archaeolithoporella hidensis; Flügel and Flügel-Kahler, p. 160-161, pl. 10, figs. 2, 4, 7 (with five references in synonymy).

.1981 Archaeolithoporella; Flügel, text-fig. 4a-e, $5 \mathrm{~b}, \mathrm{~d}, \mathrm{e}, 6 \mathrm{~d}, 9 \mathrm{a}, \mathrm{b}$.

v1981 Stromatolithes (...) (Archaeolithoporella); Vachard in Vachard and Montenat, p. 32-33, pl. 15, fig. 1.

1983 Archaeolithoporella; Mazzullo and Cys, figs. 2A, B, 3A-C.

1984 Archaeolithoporella; Flügel, Kochansky-Devidé and Ramovš, p. 180, 183, 186-193, 196, 209-212, pl. 24, figs. 4, 6, pl. 25, figs. 2, 3, 58 , pl. 26 , figs. $5,6,8$, pl. 27 , figs. $2,3,5$, pl.
28, fig. 4, pl. 31, figs. $1,7,10,12$, pl. 36 , fig. 3 , pl. 38, fig. 5 .

.1986a Stromatolithes; Nguyen Duc Tien, pl. 8, fig. 11 only (non fig. 9 = ? Clinortonella; nec fig. $10=$ Girvanella).

.1988

Archaeolithoporella; Senowbari-Daryan and Di Stefano, pl. 8, fig. 1.

v.1988 Archaeolithoporella; Vachard and Razgallah, fig. 1.

.1989 Archaeolithoporella; Flügel and Reinhardt, p. 507-509, 511-515, fig. 7b.

v1990 Archaeolithoporella hidensis; Vachard and Miconnet, p. 301, pl. 1, fig. 13.

1990 Archaeolithoporella; Fan et al., pl. 4, fig. 4, pl. 8, figs. 1, 3, 4, 6, pl. 10, fig. 3.

v1991 Archaeolithoporella hidensis; Razgallah and Vachard, p. 192-197, pl. 3, figs. 2-7, pl. 4, figs. $1-6$, pl. 5 , figs. $1-8$, pl. 6 , figs. $1-8$ (with 42 references in synonymy).

1991 Archaeolithoporella hidensis; Wu, p. 755, pl. 2, fig. 5, pl. 3, fig. 5 .

.1991 Archaeolithoporella; Flügel et al., pl. 42, fig. 9, pl. 48, figs. 6-10.

.1991 Archaeolithoporella; Riding and Guo, figs. 15, 16.

.1991 Archaeolithoporella; Toomey, p. 213, text-fig. 3 p. 214, pl. 31, figs. 1, 2, pl. 33, fig. 5, pl. 34, fig. 9.

?.1993 stromatolith crusts; Chuvashov et al., pl. 4, figs. 3, 4.

v1993a Archaeolithoporella hidensis; Vachard et al., pl. 2, fig. 3.

.v1993 Archaeolithoporella; Dawson, p. 9, 12, 16, 31 (no illustration).

.1994 Archaeolithoporella; Wang et al., p. 725-731, figs. 2, 3, 4.1-9, 5, 6.

1994 Stromatolite; Fontaine et al., pl. 30, fig. 4.

.1995 Archaeolithoporella; Pratt, p. 80, 82, 83, 84, 87 ?, 103, text-figs. 38, 39A, 39B p. 84.

1995 Archaeolithoporella/Shamovella (sic) boundstone; Le Mone, p. 141 (no illustration).

1995 Archaeolithoporella sp.; Forke, p. 240, fig. 17.8.

.1998 Archaeolithoporella; Kirkland et al., figs. 7AD, 8B, 18.

1999 Archaeolithoporella hidensis; Fagerstrom and Weidlich, p. 132, 136, 140, 145, 146, $148,150,151,152,153$, text-fig. 2 p. 133 , tabl. 1 p. $134,132,136,140,145,146,148$, $150,151,152,153$, pl. 14 , figs. 1,2 , 4, pl. 15 , fig. 4 , pl. 16 , fig. 4 , tabl. 3 p. 142 , text-fig. 7 p. 151.

.2001 Archaeolithoporella; Moore, fig. 5.15A, B.

v.2001a Archaeolithoporella; Vachard in Vachard et al., p. 382, figs. $12.6,14.9$. 
v.2001b Archaeolithoporella hidensis; Vachard in Vachard et al., pl. 3, fig. 7.

.2001 Archaeolithoporella; Shen and Kawamura, pl. 23 , fig. 3 , pl. 24 , figs. $2,4,5$, pl. 25 , figs. 1 , 2.

2002 Archaeolithoporella hidensis; Weidlich, p. 339, 341, 357, text-figs. 5.D.3, 7.C.3, 13.D.1, 13.D.2, 13.F.1.

v2003a Archaeolithoporella; Krainer et al., p. 8, 17 (no illustration).

2003 Archaeolithoporella; Noé, pl. 4, fig. 8, pl. 9, figs. $2-4$, pl. 13 , fig. 5 , pl. 15 , figs. $5-7$, pl. 21 , figs. $1,6-8$.

2003 Archaeolithoporella hidensis; Noé, pl. 13, figs. 3, 4 .

2003 Archaeolithoporella; Chen et al., p. 121, 124, $126,128,131,132$, pl. 16, figs. $2,6,7$, pl. 17 , figs. 1-3, 6, 7, pl. 18, fig. 1 .

.2004 Archaeolithoporella sp.; Flügel, fig. 7.14B, pl. 42 (full page), fig. 10.59, pl. 98, figs. 5, 8, pl. 145, fig. 1.

. ?2005 Archaeolithoporella hidensis; Fagerstrom and Weidlich, p. 508, 509, 511, 512 (no illustration).

2007 Archaeolithoporella; Bensing, fig. 1.1 p. 6.

.2007b Archaeolithoporella; Krainer and Vachard, p. 291, 294, figs. 24-26.

v2011 Archaeolithoporella sp.; Vachard and Moix, p. 152 (no illustration).

v2011 Archaeolithoporella hidensis; Moix et al., p. 68,75 , pl. 1 , figs. 17,18 , pl. 4 , fig. $15 \mathrm{~b}$.

v2013 Archaeolithoporella hidensis; Moix et al., p. 408 (no illustration).

v2013 Archaeolithoporella; Kossovaya et al., p. 351, 353, fig. 5a(A) (no illustration).

2013 Archaeolithoporella; Wahlman and Tasker, p. 305, 311 (no illustration).

2013 Archaeolithoporella; Wahlman et al., p. 1895, 1903, 1905, 1908, 1912, 1916, tabl. 1, figs. 15C, 15D, 17C.

v2015 Archaeolithoporella hidensis; Angiolini et al., table 2a.

v2016 Archaeolithoporella hidensis; Angiolini et al., fig. 11.A.

Description. Millimeter- to centimeter-sized bioconstructions. Thickness of laminae $=35-50 \mu \mathrm{m}$. Thickness of dark layers ("walls") $=10-35 \mu \mathrm{m}$; thickness of clear layers (trichomes?) $=20-30 \mu \mathrm{m}$. Commonly, these colonies are associated with botryoid cements in the Carnic Alps, Jebel Tebaga, Darvas, El Capitan and South China (Flügel, 1980, 1981; Flügel et al., 1984, 1991; Razgallah and Vachard, 1991; Kirkland et al., 1998; Moore, 2001; Noé, 2003; Flügel, 2004; Angiolini et al., 2016; and this study).
Remarks. We adopt here the description and interpretation of Vachard et al. (2001a) for Archaeolithoporella. Biosedimentologically, the largest mounds of the Carnic Alps occur in the Trogkofel limestone, and are composed of Tubiphytes-Archaeolithoporella boundstone, which shows some similarities to the "Tubiphytes thickets" of stage 2 of the massive Capitan Reef Complex of the Guadalupe Mountains of New Mexico/West Texas (Krainer, 2007).

Occurrence. Possibly present as early as the Asselian in the Urals (Chuvashov et al., 1993), the species as a double acme in the western Paleotethys; first in the Artinskian-Kungurian (e.g., in the Carnic Alps and Darvas: Flügel and Flügel-Kahler, 1980 and Angiolini et al., 2016), then in the Capitanian (e.g., Apennines, Italy; Vachard and Miconnet, 1990); Jebel Tebaga, Tunisia (Razgallah and Vachard, 1991); western Sicily (Italy; early GuadaIupian re-dated here; Flügel et al., 1991); Turkey (Vachard and Moix, 2011; Moix et al., 2011); El Capitan Reef (New Mexico, USA; Babcock, 1979; Noé, 2003; Flügel, 2004); South China (Shen and Kawamura, 2001); Late Permian of Greece (Vachard et al., 1993a); up to the Changhsingian of South China (e.g., Riding and Guo, 1991; Flügel, 2004). In the Carnic Alps, the Archaeolithoporella crusts were known in OPK (Homann, 1972); Upper Pseudoschwagerina Limestone Member and Trogkofel Group (Flügel, 1979; Vachard and Krainer, 2001b); Trogkofel (Flügel, 1966; Krainer, 2007); Tarviser Brekzie (Flügel, 1980); in Seikofel, Forni Avoltri, Straniger Alm, Treßdorfer Alm, and TarvisGoggau (Flügel and Flügel-Kahler, 1980); and numerous other localities (Flügel and FlügelKahler, 1980). In this study, the best specimens come from the Trogkofel Fm (samples GTB4_1; GTB11_1; GTB11_2; TK60_1; TK60_AP; and TK68_1).

\section{Incerti ordinis \\ Family CHABAKOVIACEAE Kordé, 1973}

Synonym. Renalcidae Riding and Brasier, 1975; Renalcidaceae nomen translat. Vachard and Beckary, 1991 emend. Vachard, 1993.

Description. Globose trichomes, hemispherical to reniform, entirely calcified or hollow, arranged in uniseriate, ramified series. Wall microgranular, dark or grayish.

Remarks. The family Renalcidae was interpreted by Riding and Brasier (1975) as composed of the "oldest foraminifers in the world". It is now unanimately admitted as a group of cyanobacteria (calcibionta or calcimicrobes; Luchinina, 2009). Whatever the reciprocal interpretations of Renalcis 
and Chabakovia Vologdin, 1932, the prioritary name for the family is Chabakoviaceae, even if Renalcidae is most commonly used in the literature.

Occurrence. The family is principally Early Cambrian in age, but the genus Renalcis displays other later acmes (Frasnian, Viséan and Bashkirian) and may extend up to the Permian (see below). Its appearance is possibly situated in the latest Precambrian (Late Vendian; Luchinina and Terleev, 2004).

Genus RENALCIS Vologdin, 1932 emend. Luchinina, 2009

Type species. Renalcis granosus Vologdin, 1932, by original designation.

Synonyms. See Mamet and Roux (1983), Mamet (1991), Vachard (1993) and Luchinina (2009).

Diagnosis. Chabakoviaceans with hollow, inflated, hemispherical to reniform trichomes, arranged in numerous ramified series. Wall dark microgranular, relatively thick and with small cracks at the base. The hollow parts of trichomes and small cracks in walls are filled with white microsparite.

Occurrence. Neoproterozoic-Frasnian; probably cosmopolitan (Roux, 1985; Vachard, 1993; Stephens and Sumner, 2002). Late Viséan-Bashkirian in Paleotethys and Urals shelves (Vachard, 1977a, 1977b; Saltovskaya, 1984a). Early Moscovian of Japan (Mamet, 2002) and Spain (Samankassou et al., 2013). Very rare in Early Permian of the Carnic Alps (Vachard and Krainer, 2001b; and this work) and Middle Permian of southernmost Tunisia (Vachard and Razgallah, 1988).

Renalcis cf. granosus Vologdin, 1932

Figure 12.1, Figure 27.4

*1932 Renalcis granosus Vologdin, p. 15, fig. 9.

1955 Izhella nubiformis Antropov, p. 47, pl. 1, figs. 4-6.

1959 Renalcis granosus; Reitlinger, p. 12, pl. 2, fig. 7.

p1983 Renalcis granosus; Mamet and Roux, p. 9295 , pl. 12, figs. $1-10$, pl. 13, figs. $1-9$, pl. 14, fig. 1-10 (with synonymy).

v1987 Renalcis sp.; Delvolvé and Perret, pl. 2, fig. 3.

v.1988 Quatre "cloques" de Renalcis; Vachard and Razgallah, fig. 1.

v.1989b Renalcis ex gr. nubiformis; Vachard et al., p. 701 , pl. 1, fig. 7 (with two references in synonymy).

v1991 Renalcis ex gr. nubiformis; Vachard and Beckary, p. 321, pl. 1, figs. 1, 2.
?.2001 Izhella; Chuvashov and Anfimov, fig. 6a (most probably Palaeonubecularia).

v.2001b Renalcis; Vachard and Krainer, p. 178, pl. 3, figs. 5,6 .

2002 "Renalcis granosus"; Mamet, pl. 1, fig. 6.

2004 Renalcis; Shen and Webb, fig. 4B.

2009 Renalcis granosus; Luchinina, pl. 13, fig. 1.

2013 Renalcis; Samankassou et al., fig. 5.1.

Description. Length of thalli = up to $500 \mu \mathrm{m}$; width of thalli $=550 \mu \mathrm{m}$; average diameter of a chamber/ cell $=200 \times 100 \mu \mathrm{m}$; "wall" thickness $=60 \mu \mathrm{m}$.

Remarks. This identification of other Permian Renalcis confirms the report of Vachard and Razgallah (1988) of late Middle Permian Renalcis in Jebel Tebaga (Tunisia) questioned by Riding and Guo (1991). On the other hand, this paper of Vachard and Razgallah (1988) illustrated excellent Mid-Permian epiphytaceans Tharama Wray, 1967, however ignored by Săsăran et al. (2014, p. 8) in their review of the post-Late Devonian to pre-Late Jurassic epiphytaceans.

Occurrence. As for the genus. In the Carnic Alps, only two specimens were found by Vachard and Krainer (2001b, plate 3, figures 5, 6; sample ZKO20), and two specimens were found during this study in the Trogkofel Fm (samples GBT11_2 and TK20_1_1).

Genus GAHKUMELLA Zaninetti, 1978

Type species. Gahkumella huberi Zaninetti, 1978, by original designation.

Diagnosis. Colonies of uniseriate, hollow, crescentic cells. Wall dark microgranular.

Occurrence. Late Permian of Iran (Zaninetti, 1978). Roadian of Turkey (Moix et al., 2013; Vachard and Moix, 2013). Late Jurassic of Saudi Arabia (Hughes, 2010, 2013) and Spain (Granier, 1986). The Cretaceous genus Cretacicladus Luperto Sinni, 1979 (see Săsăran et al., 2014 with references therein) is probably related to Gahkumella.

\section{Gahkumella sp. \\ Figure 11.3}

Description. Height of thalli $=200 \mu \mathrm{m}$; diameter of thallus $=100-200 \mu \mathrm{m}$; thickness of lamellae $=5-7$ $\mu \mathrm{m}$; thickness of interlamellae $=7-10 \mu \mathrm{m}$; diameter of central cavity $=70-100 \mu \mathrm{m}$.

Occurrence. As for the genus. In the Carnic Alps, in this study, only one specimen was found in the Zweikofel Fm (sample GB 157_13).

Order OSCILLATORIALES Elenkin, 1934 or PROAULOPORALES Luchinina, 1975

Family GIRVANELLACEAE Luchinina, 1975 
Description. Cylindrical trichomes with no, rare or frequent pseudoramifications. Wall dark microgranular.

Occurrence. Neoproterozoic-Cretaceous, cosmopolitan.

Genus GIRVANELLA Nicholson and Etheridge, 1878

Type species. Girvanella problematica Nicholson and Etheridge, 1878, by original designation.

Description. Cylindrical trichomes without pseudoramifications. Wall dark microgranular.

Remarks. See the details on the calcification of the trichomes of cyanobacteria in e.g., Pentecost and Riding (1986) and Merz (1992).

Occurrence. Neoproterozoic-Early Cretaceous (Johnson and Konishi, 1956; Flügel, 2004) or Late Cretaceous (Camoin, 1989), cosmopolitan and eurytope. Modern equivalents were described by Riding (1975).

\section{Girvanella sp.}

Figure 11.4

Description. Free and well-preserved Girvanella are rare in our material, but they appear generally completely micritized and only present within cyanobacterial crusts. These latter are generally associated with Claracrusta in complex biopisolites of Ottonosia-type (sensu Vachard, 1980 = Osagiatype sensu Mamet et al., 1987 or sensu Mamet, 1991). This type of grain and microecosystem is common during the Permian; however, it appears in the early Serpukhovian of Spain (Cózar et al., 2003) and even in the latest Visean of Morocco; i.e., since the concomitant FAD (first appearance datum) of Claracrusta (Vachard and Cózar, 2010, and see below). Outer diameter $=50 \mu \mathrm{m}$; inner diameter $=25 \mu \mathrm{m}$; wall thickness $=10-13 \mu \mathrm{m}$.

Remarks. The following taxa of Girvanella have been traditionally mentioned in the region: Girvanella cf. ducii Wethered, 1890 (by Flügel, 1979, 1980); G. cf. magna Johnson, 1946; G. cf. texana Johnson, 1950 (by Flügel, 1968, 1979); G. kordeae Güvenç, 1975; G. sp. A; and G. sp. B (by Kochansky-Devidé, 1970a); Girvanellen (by Flügel, 1980); and "Algen-Kruste"; Flügel and Flügel-Kahler, 1980; from LP (Lower Pseudoschwagerina Limestone Member, currently Schulterkofel Formation; late Gzhelian to earliest Asselian in age) to TK (Trogkofel Group; middle Artinskian-early Kungurian) by Flügel (1979, plate 1, figure 4). In reality, 1) no Girvanella ducii were observed in our material; 2) G. kordeae and G. texana are poorly defined species; 3) G. cf. kordeae was renamed Ortonella myrae Rácz by Flügel and Flügel-Kahler (1980, plate 11, figures 9 and 12), 4) Girvanella kordeae and $\mathrm{G}$. sp. B belong probably to the ellesmerellids (see the second part of this study).

Occurrence. Permian girvanellaceans are cosmopolitan. In the Carnic Alps, they were especially described from Forni Avoltri. Our main fossiliferous samples are located in the Grenzland Fm (sample GB19_1b); Zweikofel Fm (samples GB35_4; GB60_1_2; GB60_5; ZK97_13; ZK201_10); Zottachkopf Fm (samples TKS3_2; TKS12_4; TKW4_4; TKW 4_1a; TKW6B_3; TKW9_1; TKW9_2; TKW10_2b; TKW10_4; TKW13B_4; TNA16_2_1; TNA16_2_4a; TNA18_1; TNA18_2_2; TNA18_2_3; TNA1_1_4; TNC5_2; TNC5_3_2; Z6B_1; Z6B_3a; Z6B_3b); and Trogkofel Fm (sample TKS14_1a).

Genus MITCHELDEANIA Wethered, 1886 emend. Mamet and Roux, 1975a non Wood, 1941

Type species. Mitcheldeania nicholsoni Wethered, 1886 emend. Mamet and Roux, 1975a, by original designation.

Description. Relatively large cylindrical trichomes with pseudoramifications. Wall dark microgranular.

Remarks. In our knowledge, this genus was not yet mentioned in Permian beds.

Occurrence. Ordovician-Mississippian, cosmopolitan (Roux, 1985; Mamet, 1991; Mamet et al., 1992); Pennsylvanian of Greenland and Japan (Mamet and Stemmerik, 2000; Mamet, 2002).

\section{Mitcheldeania sp. \\ Figure 11.5}

Description. Although rare, the observed specimens display all the genus criteria with the dichotomous filaments and the following measurements: Outer diameter $=40-50 \mu \mathrm{m}$; inner diameter $=30-$ $35 \mu \mathrm{m}$; wall thickness $=5-7 \mu \mathrm{m}$.

Occurrence. This study: Grenzland Fm (sample GB17_2b).

Genus KOIVAELLA Chuvashov, 1974

Type species. Koivaella permiensis Chuvashov, 1974 , by original designation.

Description. Cylindrical trichomes with distal, oblique pseudoramifications. Wall dark microgranular.

Remarks. Several tubular undivided microfossils with a dark microgranular wall are difficult to discriminate during the Permian and the Triassic. There are 1) primitive tubular foraminifers Earlandia Plummer, 1930, and/or Hyperammina Brady, 1878, and/or Aeolisaccus Elliott, 1958, of the authors (see Glintzboeckel and Rabaté, 1964; Berczi-Makk, 1987; Vachard et al., 2010; Krainer 
and Vachard, 2011; Nestell et al., 2015; Vachard, 2016a, 2016b; and the second paper of this study); 2) uncoiled parts of calcivertellid foraminifers (see, e.g., Homann, 1972, plate 9, figures 69, 70); 3) tubular (initial?) parts of tubiphytids; 4 ) a last group of dark tubules might correspond to Koivaella devoid of ramifications; especially, Aeolisaccus gracilis Pantić, 1972 (see also Flügel, 1966, plate 10 , figure 3 ); 5) tubular cyanobacteria similar to Girvanella or Microcoleus Desmazières, 1830, ex Gomont, 1892 (e.g., Bignot, 1972; Golubić, 1973; Colin and Vachard, 1977).

Occurrence. Late Pennsylvanian-Late Triassic of the Urals, Carnic Alps, Sicily, Slovenia, Greece, Tunisia, southern Turkey (Hazro), Iran (Alborz, Zagros), Afghanistan, Thailand, Sumatra, Malaysia and New Mexico (USA) (compiled in this study).

Koivaella ex gr. permiensis Chuvashov, 1974 Figure 12.3, 12.4, 12.6-10

1964 Hyperamminidae; Glintzboeckel and Rabaté, pl. 58, figs. $1,2$.

*1974 Koivaella permiensis Chuvashov, p. 35, pl. 22, figs. 1-11.

v1980 Koivaella permiensis; Vachard, p. 336-337, pl. 22, figs. 6, 8, 14, 15, pl. 24, fig. 14 .

1980 Koivaella permiensis; Flügel, p. 87 (no illustration).

1980 Gegabelte Röhrchen, vergleichbar mit Koivaella permiensis; Flügel and Flügel-Kahler, pl. 11, fig. 10.

v1981 Koivaella permiensis; Vachard in Vachard and Montenat, p. 29, pl. 2, figs. 1, 4-6, pl. 4, figs. 9,12 , pl. 5 , fig. 12 , pl. 12 , fig. 8 (with two references in synonymy).

1983 Koivaella permiensis; Jenny-Deshusses, p. 161 , pl. 17, fig. 7 (with two references in synonymy).

p.1984 Tube-like microfossils; Flügel et al., pl. 42, figs. 1-8 (neither pl. 42, figs. 9-11, nor pl. 29, fig. 1).

1984 Koivaella permiensis; Senowbari-Daryan, p. 13-15, pl. 1, fig. 5, pl. 2, figs. 1-8, pl. 3, fig. 8 , pl. 4 , figs. 6,7 , pl. 6 , fig. 5 , pl. 10 , fig. 1 (with five references in synonymy).

v1984 Koivaella permiensis; Fontaine and Vachard, p. 51 (no illustration).

v1986 Koivaella permiensis; Fontaine and Vachard, p. 113 (no illustration).

?1986 Parathurammina sp.; Nguyen Duc Tien, pl. 1, fig. 15 (apparently similar to the bases of groups of trichomes illustrated by Vachard, 1980).

v1988 Koivaella permiensis; Fontaine et al., p. 66, fig. 3: 2. v1990 Koivaella; Caridroit et al., p. 346 (no illustration).

v1991 Koivaella; Razgallah and Vachard, p. 197, pl. 3, figs. 5, 6 .

1993 Koivaella permiensis; Chuvashov et al., pl. 14, fig. 1.

v1993a Koivaella permiensis; Vachard et al., pl. 1, fig. 8, pl. 3, fig. 5, 6?, pl. 4, fig. 10 .

1993 Koivaella; Senowbari-Daryan and Flügel, pl. 9, fig. 1-6.

1994 Koivaella permiensis; Fontaine et al., pl. 45, fig. 2.

v.1997 Koivaella; Fontaine et al., tabl. 2, p. 144 (no illustration).

?.1999 unnamed tubules; Fagerstrom and Weidlich, tabl. 3 p. 142 (no illustration).

v2001b Koivaella permica (sic); Vachard and Krainer, pl. 3, fig. 7.

v2001b Koivaella permica (sic); Vachard et al., pl. 3, figs. 1, 5.

2003 Koivaella permiensis; Noé, pl. 17, fig. 3, pl. 18, fig. 1.

2003 Large branched tubes; Noé, pl. 18, fig. 2.

2003 Cluster of thin-walled non-branched micritic tubules; Noé, pl. 18, fig. 3.

$2003 \quad$ Non-branched thin tubules; Noé, pl. 18, fig. 4.

2004 Koivaella; Flügel, pl. 98, fig. 3.

v2009 Koivaella permiensis; Krainer et al., pl. 3, figs. 8, 9, 12.

v2011 Koivaella permiensis; Moix et al., p. 68, 75 (no illustration).

v2011 Koivaella sp.; Vachard and Moix, p. 152 (no illustration).

2013 Koivaella; Senowbari-Daryan, p. 103, 105, fig. $15 \mathrm{~d}-15 \mathrm{f}$ (non fig. $15 \mathrm{~g}=$ Earlandia).

v.?2015 Koivaella permiensis; Krainer et al., p. 24, figs. 22.15, 23.4 .

v?2017a Koivaella; Krainer et al., p. 20 (no illustration).

Description. Although rare, the observed specimens display all the specific criteria with the following measurements: Outer diameter $=70-115 \mu \mathrm{m}$, inner diameter $=10-15 \mu \mathrm{m}$, wall thickness $=20-40$ $\mu \mathrm{m}$, angle of pseudoramification $=30-40^{\circ}$.

Occurrence. As for the genus, worldwide. In the Carnic Aps, the species-group is known from Forni Avoltri (Flügel, 2004) and Zweikofel Fm (Vachard and Krainer, 2001b: sample ZK215x). This study: Zottachkopf Fm (samples TNB3_1_6; TNB13_4; TNC5_1); and Trogkofel Fm (samples TK9_1; TK 50_1_4; TK 50_1_5; TK_50_1_7_10).

Family GARWOODIACEAE Shuysky, 1973 

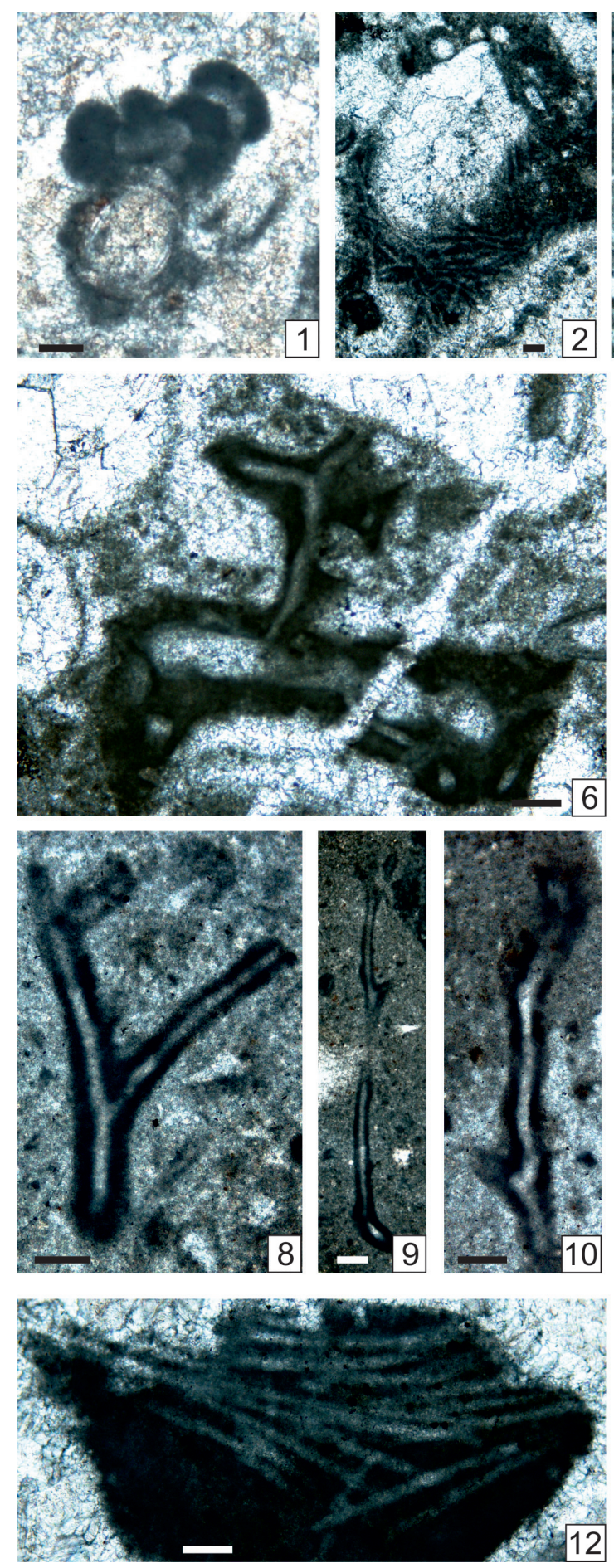
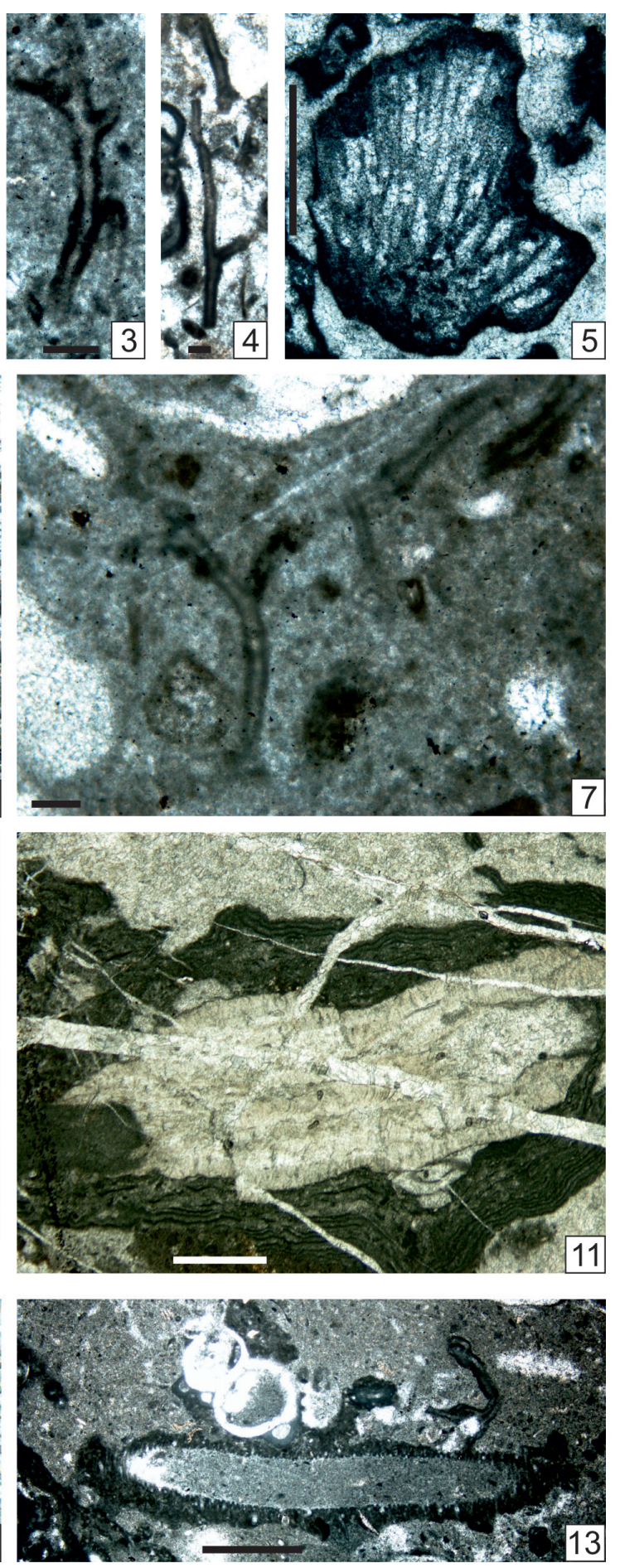

FIGURE 12. 1. Renalcis cf. granosus Vologdin, 1932. Longitudinal section. Sample TK20_1_1. 2, 12? Clinortonella cf. goggauensis (Flügel and Flügel-Kahler, 1980). 2. Axial section with typical filaments. Sample TK6_4. 12. Axial section with trichomes or sponge microscleres. Sample TNA_4_2. 3-4, 6-10. Koivaella ex gr. permiensis Chuvashov, 1974. 3. Bifurcated filament. Sample TK9_1. 4. Another type of bifurcated filament. Sample TNB.13_4. 6. A bifurcated filament preceeded by a basal part more or less similar to a tubiphytid. Sample TNB3_1_6. 7. Several filaments. Sample TNB8_1_7. 8. Bifurcated filament. Sample TK50_1_7. 9. Another typical filament. Sample TK50_1_5. 10. Another bifurcated filament. Sample TK50_1_4. 5. Garwoodia sp. Longitudinal section showing the typical bifurcation (right). Sample TK5_3. 11. Archaeolithoporella hidensis Endo, 1961a attached on a coral? Sample TK60_1. 13. Terebella sp. Longitudinal tube. Sample TNC5_1. Scale bars: $0.1 \mu \mathrm{m}$ (Figures 12.1-12.4, 12.6-12.10, 12.12) and $1 \mu \mathrm{m}$ (Figures $12.5,12.11,112.13)$. 
Description. Colonies of cylindrical trichomes with frequent ramifications displaying various angles and types of bifurcation. Wall dark microgranular.

Remarks. Prior to the translation of Shuysky (1973), the subfamily was first named by Endo (1961b, p. 24), but was also attributed to Johnson (1964, p. 99) by Emberger (1976).

Occurrence. ?Cambrian-Ordovician-Permian, cosmopolitan (Mamet, 1991). Modern equivalents possibly exist (Riding, 1975); therefore, this morphogenus would be known during the whole fossiliferous times.

Genus CLINORTONELLA Vachard and Moix, 2013

Type species. Ortonella goggauensis Flügel and Flügel-Kahler, 1980, by original designation.

Synonym. Ortonella sensu Flügel and FlügelKahler (1980) (part.) (non sensu Garwood, 1914); ?stromatolites (part.).

Description. Hemispherical colonies composed of numerous, cylindrical, radiating and ramified trichomes. The ramification is always at acute angle, and occasionally in-diapason. Wall dark microgranular.

Occurrence. Goggau Limestone (Kungurian) of the Carnic Alps; questionable in the Capitanian of Cambodgia; Artinskian-early Wordian of the Lycian Nappes (SW Turkey; Vachard and Moix, 2013).

Clinortonella cf. goggauensis (Flügel and FlügelKahler, 1980)

Figure 12.2, 12.12?

?1979 Girvanella permica Pia; Nguyen Duc Tien, pl. 27, fig. 14.

1980 Ortonella goggauensis Flügel and FlügelKahler; Flügel, pl. 4, figs. 1, 5, 6 (nom. nud.).

*1980 Ortonella goggauensis Flügel and FlügelKahler, p. 168, 170, 172, pl. 11, figs. 3?, 5-8.

?1986a Stromatolithes; Nguyen Duc Tien, pl. 8, fig. 9 only (non fig. $10=$ Girvanella; nec fig. $11=$ Archaeolithoporella).

?.1986b Girvanella permica Pia; Nguyen Duc Tien, pl. 8, fig. 9.

2013 Clinortonella goggauensis n. gen. n. comb.; Vachard and Moix, p. 15, fig. 9.5-9.7.

Description. Outer diameter $=1250 \times 600 \mu \mathrm{m}$, inner diameter $=10-15 \mu \mathrm{m}$, angle of pseudoramification $=20-30^{\circ}$.

Occurrence. Early Permian of the Carnic Alps and Turkey, and perhaps Middle Permian of Cambodgia (compiled in this study). In the Carnic Alps, Trogkofel Limestone of Sexten and Forni Avoltri (Flügel, 1980; Flügel and Flügel-Kahler, 1980). This study: basal Zweikofel Fm (sample GB35_4?);
Zottachkopf Fm (sample TNA4_2); and Trogkofel Fm (sample TK6_4).

$$
\text { Genus GARWOODIA Wood, } 1941
$$

Type species. Mitcheldeania gregaria (Nicholson, 1888) emend. Wood, 1941, by original designation. Description. Cylindrical trichomes with frequent ramifications, with the second branch re-becoming rapidly parallel with the first branch. Wall dark microgranular.

Occurrence. Ordovician-Permian (Roux, 1985; Vachard et al., 1989b) or Devonian-Cretaceous (Flügel, 2004), probably cosmopolitan despite rarely cited.

\section{Garwoodia sp.}

Figure 12.5

?.1979 Garwoodia gregaria (Nicholson); Flügel, p. 572 (no illustration).

1980 Garwoodia sp.; Flügel and Flügel-Kahler, p. 166 , pl. 9 , figs. 6,8 .

Description. Outer diameter of colonies $=2000 \mathrm{x}$ $2100 \mu \mathrm{m}$; inner diameter of trichomes $=75-100$ $\mu \mathrm{m}$; thickness of calcification between trichomes = 10-15 $\mu \mathrm{m}$.

Remarks. The genus was mentioned but not illustrated from the Upper Pseudoschwagerina Limestone (Zweikofel Formation; early Artinskian in age) by Flügel (1979, p. 572).

Occurrence. In the Carnic Alps: Trogkofel-Kalk of Forni Avoltri and Goggau Limestone near GoggauTarvis (Flügel and Flügel-Kahler, 1980). This study: Trogkofel Fm (sample TK5_3).

Phylum RHODOPHYTA Wettstein, 1901 Class and order undeterminated

Family ELIANELLACEAE Granier in Granier and Dias-Brito, 2016

Genus PARACHAETETES Deninger, 1906

Type species. Parachaetetes tornquisti Deninger, 1906, by original designation.

Description. Thalli large, fan-shaped, with numerous cellular files whose vertical and horizontal walls are well preserved, well calcified, and regularly arranged. Wall dark microgranular. Walls and/ or thalli are often recrystallized taphonomically into whitish neosparite. Secondary algal borings affecting these neosparitized thalli cannot be confused with algal filaments.

Remarks. Some identifications of Parachaetetes are disputable. For example, Cretaceous and Paleocene species of this genus, such as Parachaetetes asvapatii "Pia in Rao and Pia, 1936" illustrated by Johnson and Kaska (1965), and reillustrated by Granier et al. (2017), belong to 
Elianella elegans Pfender and Basse, 1948. In contrast, some "Solenomeris sp." of Johnson and Kaska (1965) belong to Parachaetetes sp. (Granier et al., 2017). Parachaetetes and other elianellaceans can present a diagenesis which mimics that of some Bryopsidales (Vachard et al., 1989a; Flügel et al., 1992; Senowbari-Daryan and Zamparelli, 2005; Senowbari-Daryan et al., 2008), especially the morphogenus Poncetellina Mamet and Roux, 1984 (for Poncetella Mamet and Roux, 1983 pre-occupied), described as Codiale but with a type species originally, and very probably correctly, called Solenopora erecta Poncet, 1971. Similarly, there is a species described as Pycnoporidium ortonelloides, redescribed here after, which recombine the genus and species names evokating both groups.

Occcurrence. The genus Parachaetetes is relatively abundant in the latest Devonian and Tournaisian (Pia, 1937; Berchenko, 1982; Mamet and Rudloff, 1972; Mamet and Roux, 1983; Ivanova and Bogush, 1992; Shen and Webb, 2004). It is relatively rare from Viséan to the Wordian. In turn, they are relatively abundant in the late Capitanian of Jebel Tebaga, Tunisia (Vachard et al., 1989a), and the Capitanian of the southern USA with "Solenopora" texana (see Johnson, 1950; Noé, 2003) is also present in the late Changhsingian of South China (Flügel and Reinhardt, 1989; Fan et al., 1990). They are well known from Late Triassic to Eocene (Peterhans, 1929; Flügel, 1975; Aguirre and Barattolo, 2001).

Parachaetetes ortonelloides (Endo, 1961c) $n$. comb.

Figure 13.1, 13.3-5

*1961c Pycnoporidium ortonelloides Endo, p. 83, pl. 1, pl. 2, pl. 3, fig. 1.

1961d Pycnoporidium ortonelloides; Endo, p. 122, pl. 7, fig. 5.

?1968 Solenopora cf. texana Johnson; Flügel, p. 55 (no illustration).

1976 Pycnoporidium ortonelloides; Emberger, $p$. 104 (no illustration) (with three references).

?1979 Solenopora centurionis Pia; Flügel, p. 572 (no illustration).

?1979 Solenopora texana Johnson; Flügel, p. 572 (no illustration).

1980 Pycnoporidium ortonelloides; Flügel and Flügel-Kahler, pl. 9, figs. 1, 2.

?1980 Solenopora cf. centurionis Pia; Flügel and Flügel-Kahler, pl. 9, figs. 3, 5.

1980 Ortonella densa Nguyen Lan Tu; Flügel and Flügel-Kahler, p. 167, pl. 9, fig. 7.

?2003 Parachaetetes sp.; Noé, pl. 14, fig. 3. v?2013 Parachaetetes sp.; Kossovaya et al., p. 358, 359 , table 2, fig. $8 \mathrm{~m}, 8 \mathrm{p}$.

Description. Length of fragments $=2,800-6,300 \mathrm{x}$ $700-3,300 \mu \mathrm{m}$; width (rarely 700)-1,000-2,000 $\mu \mathrm{m}$; width of cellular files $=40 \mu \mathrm{m}$. This taxon could be a taphotaxon related to Parachaetetes lamellatus Konishi, 1954b, which was illustrated from the Trogkofel Fm by Riding and Guo (1991, figure 18, as "Solenopora"), as that was suggested by Vachard et al. (1989a).

Occurrence. Permian of Tethys, Japan and the Urals. In the Carnic Alps: Schulterkofel and Zweikofel formations (Flügel, 1979). Forni Avoltri (Flügel and Flügel-Kahler, 1980). Very rare in our material of the Zweikofel Fm (samples GB136_1; GB159_2; GB168_3; ZK99_B; ZK99a_5); and Zottachkopf Fm (sample Z9B_1).

Class FLORIDEOPHYCEAE Cavalier-Smith, 1998 Order ARCHAEOLITHOPHYLLALES Vachard and Kabanov, 2007

Remarks. The traditional idea that no genera are known between the Pennsylvanian-Permian range of Archaeolithophyllum and the first acme of the corallinaceans during the Early Cretaceous (e.g., Lemoine, 1977; Bucur et al., 2004) led Vachard and Kabanov (2007) to introduce an order Archaeolithophyllales, as distinct of the order Corallinales Silva and Johansen, 1986. However, due to the presence of relatively similar hypothalli and perithalli, both orders belong probably to the same class. Furthermore, a representative of the order Corallinales was unquestionably found in the Late Triassic: Norithamnium Senowbary-Daryan, Keupp, Abate and Vartis-Matarangas, 2002. However, the phylogeny suggested by these latter authors, with Archaeolithophyllum passing to Norithamnium by the intermediary of Archaeolithoporella is erroneous, because this latter genus belongs most probably to the cyanobacteria (see earlier).

Family ARCHAEOLITHOPHYLLACEAE

Chuvashov in Chuvashov, Luchinina, Shuysky,

Shaikin, Berchenko, Ishchenko, Saltovskaya and Shirshova, 1987

Genus ARCHAEOLITHOPHYLLUM Johnson, 1956 emend. Wray, 1964

Synonyms. Kasimophyllum Mamet and Villa, 2004.

Type species. Archaeolithophyllum missouriense (sic: missouriensum) Johnson, 1956; by original designation.

Description. Phylloid thallus, occasionally bifurcated, which occurs as isolated blades or foliate 

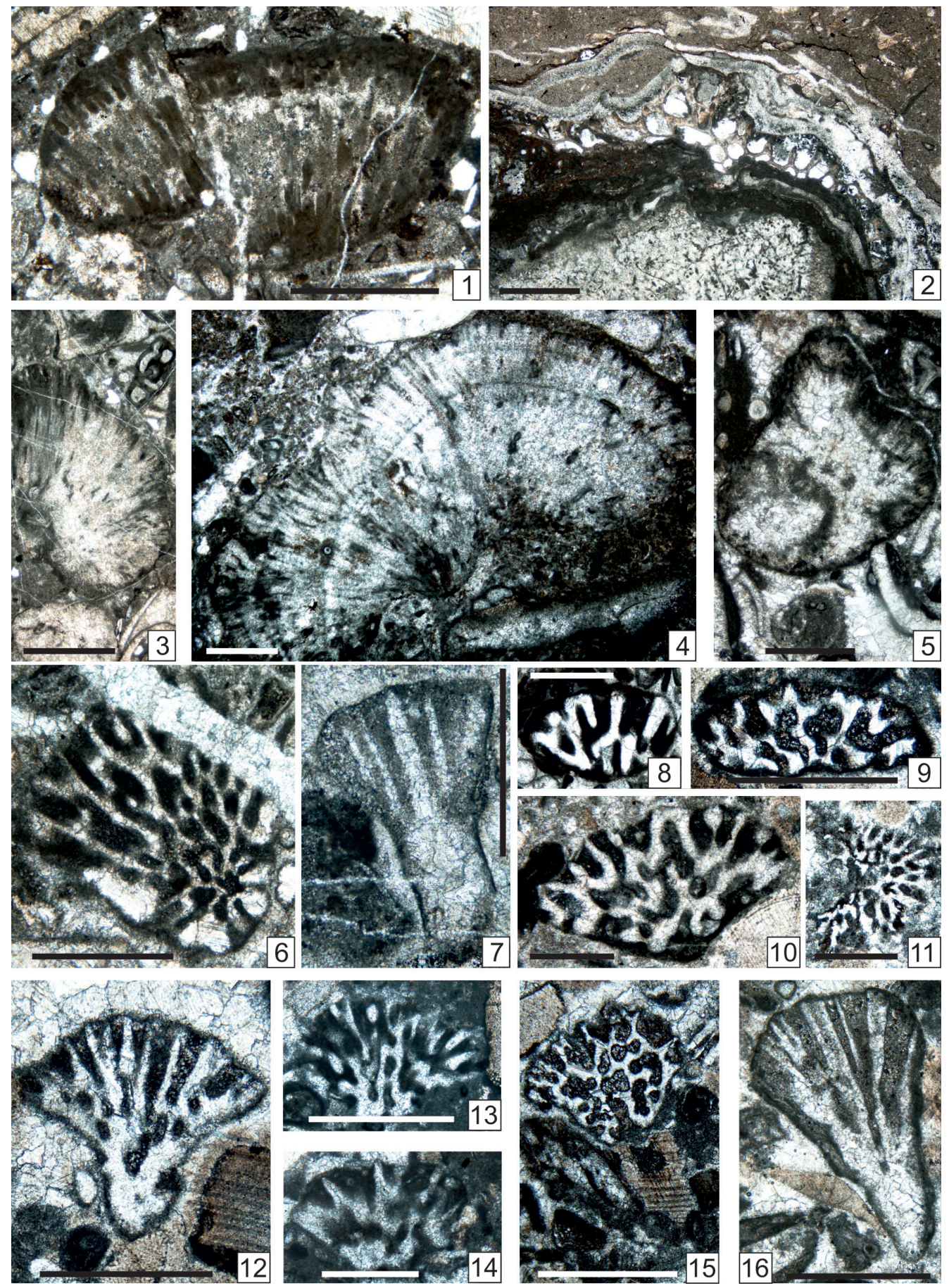

FIGURE 13. 1, 3, 4, 5. Parachaetetes ortonelloides (Endo, 1961c) n. comb. 1. Poorly preserved axial section with relatively broad recrystallized cellular files. Sample GB168_3. 3. Recrystallized axial section. Sample GB136_1. 4. Less recrystallized axial section. Sample Z9B_1. 5. Poorly preserved section resembling Ivanovia. Sample GB159_2. 2. Archaeolithophyllum lamellosum Wray, 1964. Several encrusting thalli, in axial section, attached on bryozoan, cyanobacterial crust and phylloid alga. Sample GB77_A2. 6-16. Homannisiphon morikawai (Endo, 1954). Several oblique sections. 6. Sample GB51_1 (previously published by Vachard and Krainer, 2001b, plate 13, figure 15). 7. Sample GB52_2. 8. Sample ZK99_5. 9. Sample Z1_4c. 10. Sample GB5_8_4. 11. Sample Z1_5. 12. Sample Z1_2. 13. Sample TNA2_1_2. 14. Sample TNA2_1_1. 15. Transverse oblique section. Sample Z1_3_4. 5. 16. Sample GB50_1 (previously published by Vachard and Krainer, $2001 \mathrm{~b}$, plate 13, figure 14). Scale bars: $0 . \overline{2} \mu \mathrm{m}$ (Figures 13.1, 13.2, 13.3); $0.5 \mu \mathrm{m}$ (Figures 13.8, 13.11, 13.14); and $1 \mu \mathrm{m}$ (Figures 13.4-13.9, 3.10, 12, 13.13, 13.15, 13.16). 
and encrusting multilayered masses; internal tissue differentiated into a thick hypothallus, with arcuate rows of wide polygonal cells, and a thinner perithallus, with small cells; knobby and spinose protuberances present on the upper and basal surface; conceptacles ovoid to highly arched, irregularly distributed over the upper surface of the thallus, with a single atypical aperture; cell fusions occasionally present. Cellular walls currently composed of low-Mg calcite with low $\mathrm{Sr}$ concentrations (according to Corrochano et al., 2013).

Occurrence. Early Serpukhovian (Vachard et al., 1989b, 2016; Cózar et al., 2003, 2005, 2010; Cózar, 2005) to late Capitanian; cosmopolitan. In the mounds of the Auernig Formation (Orenburgian = Newwellian), in the Carnic Alps, Archaeolithophyllum missouriense is still relatively common (Krainer, 2007); after that, very rare A. lamellosum constitute the last representatives of the genus in this region (this paper).

\section{Archaeolithophyllum lamellosum Wray, 1964} Figure 13.2

*1964 Archaeolithophyllum lamellosum Wray, p. 89, pl. 2, figs. 1, 3-5?, 7.

?1968 Archaeolithophyllum sp.; Flügel, p. 56 (no illustration).

1976 Archaeolithophyllum lamellosum; Emberger, p. 99 (no illustration) (with two references).

?1979 Archaeolithophyllum lamellosum; Flügel, p. 572 (no illustration).

1980 Archaeolithophyllum lamellosum; Flügel, p. 53, p. 63, pl. 12, figs. 2, 4.

1980 Archaeolithophyllum sp.; Flügel, pl. 13, fig. 6.

1980 Archaeolithophyllum delicatium Johnson; Flügel and Flügel-Kahler, p. 157, pl. 8, fig. 5 (with two references).

1980 Archaeolithophyllum lamellosum; Flügel and Flügel-Kahler, p. 157-158, 160, pl. 8, fig. 6, pl. 9, fig. 1 (with three references).

1983a Archaeolithophyllum cf. A. lamellosum; Toomey, pl. 21, fig. 10.

1983b Archaeolithophyllum lamellosum; Toomey, figs. $4 \mathrm{~b}-4 \mathrm{f}, 5 \mathrm{a}-5 \mathrm{~h}$.

v1992 Archaeolithophyllum lamellosum; Krainer, pl. 5, fig. 3.

1995a Archaeolithophyllum lamellosum; Krainer, p. 200, 208, 210, 211, 212 (no illustration).

1996 Archaeolithophyllum lamellosum; Skompski, p. 224-225, pl. 14, figs. 3-6.

1998 Archaeolithophyllum lamellosum; Forke et al., pl. 3, fig. 7.

v2001a "Archaeolithophyllum" lamellosum; Vachard and Krainer, p. 151 (no illustration). v2001b "Archaeolithophyllum" lamellosum; Vachard and Krainer, p. 172 (no illustration).

v2003a Archaeolithophyllum lamellosum; Krainer et al., p. 8, 14, pl. 1, fig. 6.

2003 Archaeolithophyllum lamellosum; Samankassou and West, p. 219, 225, 227, 235 (no illustration).

2003 Archaeolithophyllum lamellosum; Cózar et al., pl. 4, fig. 12.

2004 Archaeolithophyllum; Flügel, pl. 56, figs. 1, 2.

2005 Archaeolithophyllum lamellosum; Cózar, textfig. 3, p. 408, text-fig. 4, p.409, fig. 70.10-11.

2005b Archaeolithophyllum lamellosum; Cózar and Somerville, p. 90, pl. 2, fig. 3.

2005 Archaeolithophyllum lamellosum; Cózar et al., p. 14, 16, tabl. 2, fig. 4A-D.

v2008 Archaeolithophyllum lamellosum; Pille, p. 59, pl. 19, figs. 12-14.

v 2009 Archaeolithophyllum lamellosum; Krainer et al., p. 10, 12, 13, pl. 2, figs. 1-6.

2010 Archaeolithophyllum lamellosum; Cózar et al., fig. 4t.

2013 laminar red algae; Wahlman and Tasker, fig. $17 \mathrm{~F}$.

v.?2015 Archaeolithophyllum lamellosum; Krainer et al., figs. 21.23, 21.24.

v.2015 Archaeolithophyllum lamellosum; Lucas et al., fig. 9B

v2016 Archaeolithophyllum lamellosum; Vachard et al., fig. 4B.

v.?2017 Archaeolithophyllum lamellosum; Lucas et al., p. 15 (no illustration).

v.2017a Archaeolithophyllum lamellosum; Krainer et al., p. 20, 31, pl. 30, fig. 12.

Description. Encrusting thalli measuring: Length $=$ $6,000 \mu \mathrm{m}$; width $=200 \mu \mathrm{m}$.

Occurrence. As for the genus. In the Carnic Alps: Pizzul Fm (late Kasimovian/early Gzhelian) (Krainer, 1992; Vachard and Krainer, 2001a); Schulterkofel Fm to Trogkofel Fm (Flügel, 1979; Krainer, 2007). Forni Avoltri; Seikofel (Flügel, 1980); Goggau (Flügel and Flügel-Kahler, 1980). This study: Zweikofel Fm (sample GB77A_2).

Phylum CHLOROPHYTA Pascher, 1914 Class BRYOPSIDOPHYCEAE Bessey, 1907 Order BRYOPSIDALES Schaffner, 1922 Incertae familiae

Genus HOMANNISIPHON Vachard and Krainer, 2001b

Type species. Ortonella morikawai Endo, 1954; by original designation.

Description. Thallus cordiform (= heart-shaped). Sparitized skeleton formerly aragonitic. Radiate siphons beginning at the base of the thallus and 
diverging toward the apex, dichotomously branching several times. Tube cylindrical with some swollen parts. Deltoid extremities of siphons. Conceptacles not obvious.

Other species. Salopekiella? sp. sensu Mu, 1982; Anchicodium maximum Senowbari-Daryan and Rashidi, 2010.

Occurrence. Late Pennsylvanian (late Kasimovian-early Gzhelian) of Japan (Endo, 1954). Sakmarian of the Urals (Chuvashov, 1974; Kulik, 1978). Early Sakmarian (= Upper Pseudoschwagerina Limestone $=$ Zweikofel Formation) of the Carnic Alps and the Karawanken Mountains (Kochansky-Devidé, 1970a; Homann, 1972; Vachard and Krainer, 2001b). Early Permian of Tibet (Mu, 1982) and Iran (Senowbari-Daryan and Rashidi, 2010).

\section{Homannisiphon morikawai (Endo, 1954)}

Figure 13.6-16, Figure 14.1-5

*1954 Ortonella morikawai Endo, p. 219-220, pl. 19 , figs. $8,9$.

1957 Ortonella morikawai; Endo, p. 296, pl. 43, figs. 4, 5 .

1963 Ortonella morikawai; Johnson, p. 131, pl. 16, figs. 6, 7, pl. 76, figs. 5-8.

1970a Ortonella morikawai; Kochansky-Devidé, p. 212, 240, pl. 22, figs. 1, 2, pl. 24, figs. 1, 2.

.1972 Salopekiella cf. S. velebitana Milanović; Homann, p. 230-231, pl. 7, figs. 56-58.

1974 Thaiporella uralica Chuvashov, p. 19-20, pl. 5 , figs. 1,2 (non fig. 3 which is the holotype of this species and was re-illustrated by Chuvashov et al., 1993, pl. 14, fig. 14).

1976 Ortonella morikawai; Emberger, p. 92 (with four references in synonymy).

1977 Ortonella morikawaii; Flügel, p. 318 (no illustration).

1978 Ortonella cf. morikawai; Kulik, p. 190-191, pl. 3, fig. 2.

1979 Ortonella morikawai; Flügel, p. 572 (no illustration).

.?1982 Salopekiella? sp.; Mu, p. 230, pl. 4, fig. 7 (or another species of Homannisiphon).

.1988 Epimastopora?; Fontaine et al., pl. 13, fig. 1.

non 1996 Ortonella morikawai; Sano and Kanmera, pl. 59, fig. 10.

2001b Homannisiphon morikawai; Vachard and Krainer, p. 182, 184, pl. 3, figs. 13-16.

v2013 Hommannisiphon morikawai; Moix et al., p. 411, pl. 6, figs. 14, 17.

Description. Length of fragments: (rarely 500)2,300-4,500 $\mu \mathrm{m}$; width of fragments = (rarely 700)-1,000-2,000 $\mu \mathrm{m}$; siphon diameter $=50-100$ $\mu \mathrm{m}$; intersiphon width $=20-50 \mu \mathrm{m}$.
Occurrence. Late Carboniferous of Japan (Endo, 1954, 1957); Sakmarian of the Urals (Chuvashov, 1974; Kulik, 1978), West Thailand (Fontaine et al., 1988), and Turkey (Moix et al., 2013). In the Carnic Alps: Upper Pseudoschwagerina Limestone = Zweikofel Formation (Homann, 1972; Vachard and Krainer, 2001b: GB50, GB51, ZK77, and ZK88); Trogkofel Group of the Carnic Alps (Flügel, 1979) and Slovenia (Kochansky-Devidé, 1970a). In this study: Zweikofel Fm (samples GB50_1; GB51_1; GB52_2; GB58_4; ZK99_5); Zottachkopf Fm (samples TNB10_4; TNA2_1_1; TNA2_1_2; TNA3_3; Z1_2; Z1_3; Z1_4a; Z1_4b; Z1_4c; Z1_5); and Trogkofel Fm (sample TK18_4).

Family ANCHICODIACEAE Shuysky in Chuvashov, Luchinina, Shuysky, Shaikin, Berchenko, Ishchenko, Saltovskaya and Shirshova, 1987 emend. herein

Emended diagnosis. The thalli are foliate or ribbon-shaped, straight or curved, rarely undulated, sinuous, or ramified. The medullar siphons are numerous, thin, and sinuous, but rarely preserved; the cortical siphons are more rectilinear near the lower and/or outer surfaces, cylindrical or more globular (utricles), rarely bifurcated. The calcification, initially aragonitic, becomes neomicrosparitic and may occlude many parts of the thalli, especially the central zone. Conceptacles are unknown except for the genus Eugonophyllum and some species of Ivanovia.

Composition. Anchicodiae Shuysky in Chuvashov, Luchinina, Shuysky, Shaikin, Berchenko, Ishchenko, Saltovskaya and Shirshova, 1987 nom. translat. herein (= Ivanoviae Shuysky in Chuvashov, Luchinina, Shuysky, Shaikin, Berchenko, Ishchenko, Saltovskaya and Shirshova, 1987; because of the priority imposed by the family name).

Remarks. As the informal group of "phylloid algae" named by Pray and Wray (1963) is often rejected because of various paleobotanical inconsistencies, we prefer to use here the name Anchicodiaceae as already advised by Skompski (1996, p. 216), but which is still rarely used in the literature. Nevertheless, even if Shuysky in Chuvashov et al. (1987) has created the family Anchicodiaceae, he assigned, in the same publication, the genus Anchicodium to the tribe Ivanoviae, and did not create the tribe Anchicodiae; in consequence, both taxonomic units Anchicodiaceae and Anchicodiae are formally revised in this paper. This algal group was diversely interpreted (Pray and Wray, 1963; Wray, 1968; Roux, 1985; Chuvashov et al., 1987; Wahlman, 1988; Vachard et al., 1989a, 2001a, 

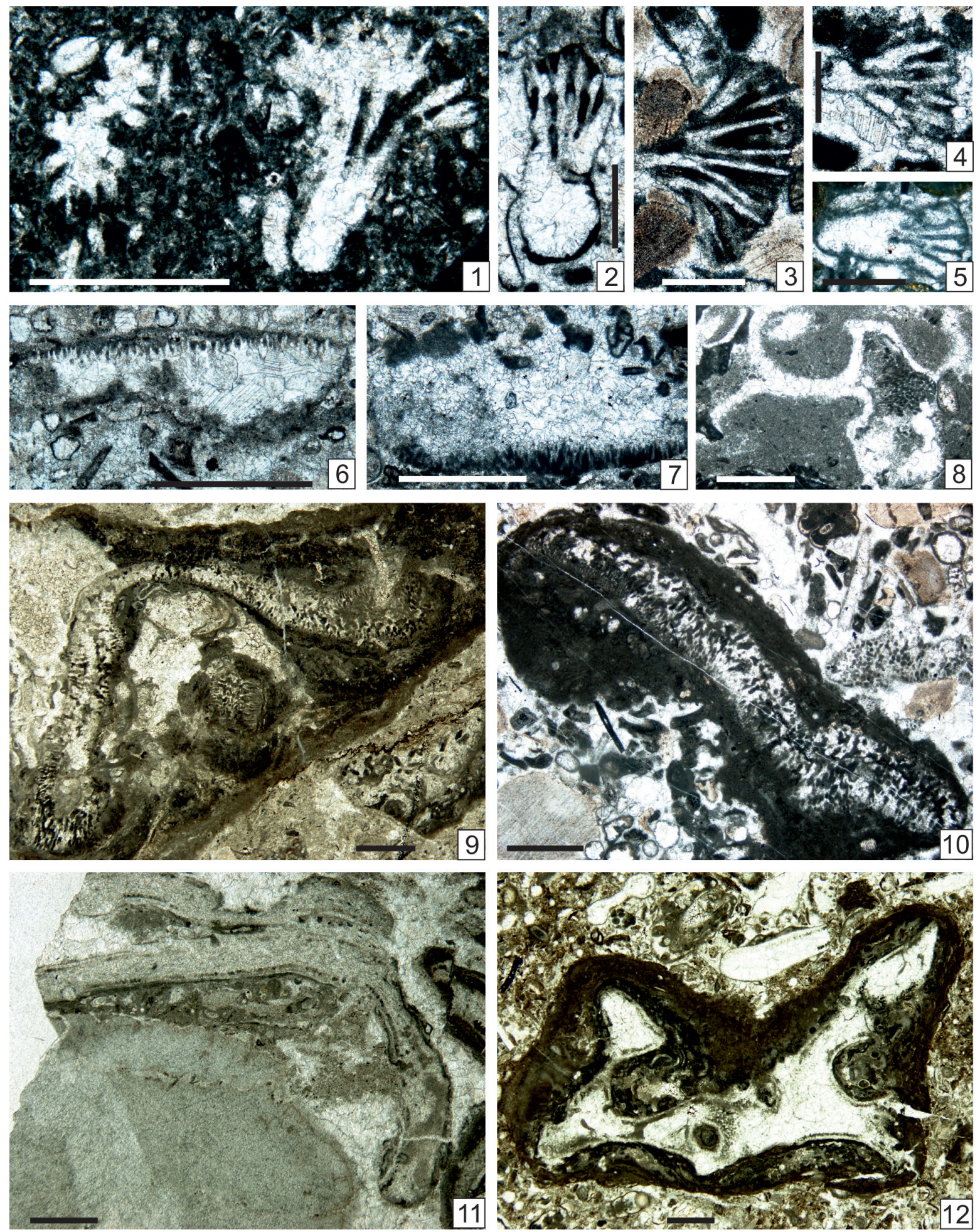

FIGURE 14. 1-5. Homannisiphon morikawai (Endo, 1954). Several oblique sections. 1. Sample TK18_4. 2. Sample TNB10_4. 3. Sample Z1_4a. 4. Sample Z1_4b. 5. Sample TNA3_3. 6-8. Ivanovia tenuissima Khorova, 1946. 6. Longitudinal section. Sample GB_76_3. 7. Longitudinal section. Sample TNA2_1_4c. 8. Tangential section. Sample TNC5_2. 9, 10. Anchicodium japonicum Endo, 1953a. 9. Longitudinal section. Sample TKS3_1. 10. Longitudinal section. Sample ZK67_A. 11, 12. Eugonophyllum magnum (Endo, 1951) emend. Konishi and Wray, 1961. 11. Longitudinal section. Sample Z2_1. 12. Longitudinal section. Sample Z7_1_width $9.5 \mu \mathrm{m}$. Scale bars: $0.1 \mu \mathrm{m}$ (Figure 14.6), 0.5 $\mu \mathrm{m}$ (Figures 14.1-14.5), and $1 \mu \mathrm{m}$ (Figures 14.7-14.11). 
2015; Kirkland et al., 1991, 1993; Baars and Torres, 1991; Riding and Guo, 1991; Dawson, 1992; Moshier and Kirkland, 1993, 1994; Pintigore, 1994; Forsythe et al., 2002; Forsythe, 2003; Schlagintweit, 2010; Granier, 2012; Corrochano et al., 2013), but it is generally considered as a group of green algae more or less similar to Halimeda (Rauzer-Chernousova and Korolyuk, 1981; Baars, 1992; Torres et al., 1992; Kirkland et al., 1993; Torres, 1995). However, some structures, similar to the conceptacles of the red algae Archaeolithophyllum, are occasionally obvious on many species of Eugonophyllum (Konishi and Wray, 1961, plate 75, figures 12, 16; Toomey and Windland, 1973, figures 8F, 8G; Toomey, 1983a, plate 21, figure 12; Vachard et al., 1989b, plate 3, figures 2-5; 1993b, plate 1, figures 1, 2); Kirkland et al., 1993, text-figure 5 p. 114; Krainer et al., 2003a, plate 7, figure 12 , plate 8 , figure 19), as well as in Ivanovia triassica Torres, 2003. Several morphogenera or and/or taphotaxa have been distinguished, and based, for a long time, on the characters summarized by Konishi and Wray, 1961, text-figure 1; Wray, 1964; Tillman, 1971; Chuvashov et al., 1987; and Toomey, 1991). These morphogenera are principally Anchicodium Johnson, 1946; Eugonophyllum Konishi and Wray, 1961; Ivanovia Khvorova, 1946; Neoanchicodium Endo in Endo and Kanuma, 1954 (non sensu Mamet et al., 1987); and several genera described more recently but which are probably junior synonyms, such as Kansaphyllum Baars, 1992 and Iranicodium Senowbari-Daryan and Rashidi, 2010. The preserved parts of the siphons, in form of utricles, generally constitute a peripheral belt, but their inner ramifications (thinner and more zigzagging) occasionally attain the center of the recrystallized thalli; this latter stage of preservation is conspicuous in Kansaphyllum, Anchicodium sensu Torres and Baars, 1992, and even, in Halimeda soltanensis Poncet, 1989, which was considered as the maximal stage of modification of Ivanovia tebagaensis Vachard, Gargouri-Razgallah and Chaouachi, 1989a (Vachard et al., 1989a), but which is most probably a species of Calcipatera (see later).

A huge literature is devoted to the phylloidalgal-buildups (Peterson and Hite, 1969; Toomey and Winland, 1973; Wilson, 1975; Cys and MazuIlo, 1977; Toomey et al., 1977; Heckel and Cocke, 1979; Mazullo and Cys, 1979; Toomey, 1980, 1991; Choquette, 1983; Chuvashov and Riding, 1984; Bowsher, 1986; Dawson and Carozzi, 1986; Fagerstrom, 1987; West, 1988; Vachard et al., 1989a; Roylance, 1990; James and Bourque,
1992; Soreghan and Giles, 1999; Wahlman, 2002; Samankassou and West, 2002, 2003; Flügel, 2004; Krainer et al., 2007; Enpu et al., 2007; Gong et al., 2009). In contrast, mounds constructed by non-phylloid algae (i.e., other bryopsidales and dasycladales) are rare (e.g., Mississippian of Nova Scotia, Arctic Archipelago of Canada: Davies et al., 1989; Carnic Alps of Austria/ltaly: Flügel, 1987; Flügel et al., 1997; Krainer, 1995a, 2007; Krainer and Vachard, 2007a; Krainer et al., 2003b; Samankassou, 1999, 2003). It is noteworthy that, in the Carnic Alps, phylloid green algal mounds often occur above or below Anthracoporella mounds (Samankassou, 2003).

Occurrence. Middle Pennsylvanian-Middle Permian, cosmopolitan. Rare in the Late Permian. Triassic representatives are disputable and possibly Permian in age.

Tribe ANCHICODIAE nomen translat. herein pro family Anchicodiaceae

Synonym. Ivanoviae Shuysky in Chuvashov, Luchinina, Shuysky, Shaikin, Berchenko, Ishchenko, Saltovskaya and Shirshova, 1987.

Diagnosis. Thalli foliate or ribbon-shaped, straight or curved, and rarely undulated. The medullar and cortical siphons are numerous, aspondyl, short, and sinuous, and all iregularly arranged. Conceptacles unknown.

Remarks. Ancestral, pre-Bashkirian Anchicodiae are generally poorly known and unnamed; they correspond partly to Mellporella Rácz, 1966a and perhaps Mellporellopsis Vachard in Vachard, Hauser, Martini, Zaninetti, Matter and Peters, 2001a, which are two typical Bryopsidales. The most remote ancestor could be Vignella Mamet and Préat, 2005, because of the shape of the cortical siphons of this Givetian alga. According to Torres and Baars (1992), true Anchicodium are possibly cylindrical and branched, whereas Kansaphyllum and Iranophyllum could be phylloid equivalents, but this suggestion is irrelevant with the shape of the type species of Anchicodium, which, as well as Anchicodium sensu Konishi and Wray (1961, text-figure 1), is more similar to Iranocodium and Kansaphyllum than to Anchicodium sensu Torres and Baars, 1992. Hence, we prefer to admit here that Anchicodium (at least by its type species), Kansaphyllum and Iranocodium, are phylloid and therefore three synonyms; the no-phylloid "Anchicodium" sensu Torres and Baars, 1992, being to be re-named.

Occurrence. ?Latest Mississippian of Algeria. Early Pennsylvanian-Early Permian, probably cosmopolitan. 


\section{Genus ANCHICODIUM Johnson, 1946}

Synonyms. ?Kansaphyllum, ?Iranophyllum. Type species. Anchicodium funile Johnson, 1946; by original designation.

Description. The thalli are foliate or ribbonshaped, straight or curved, rarely sinuous. The siphons are numerous, aspondyl and sinuous, becoming more rectilinear near the outer surface; except for this difference, the limits of the medullar and cortical zones are generally inconspicuous. Conceptacles are unknown.

Other species. Anchicodium gracile Johnson, 1946; A. undulatum Johnson, 1946; $A$. nodosum Johnson, 1946; $A$. plumosum Johnson, 1946; $A$. permianum Johnson, 1946; A. japonicum Endo, 1953a; A. fukujiense Endo and Horiguchi, 1957; $A$. ankarensis Bilgütay, 1960; $A$. densum Endo, 1961d; A. sindbadi Elliott, 1970a; A. robustum Mu, 1982; A. zhongbaensis Mu, 1982; Kansaphyllum rezakii Baars, 1992; Anchicodium iranicum Senowbari-Daryan and Rashidi, 2010; A. maximum Senowbari-Daryan and Rashidi, 2010; Iranophyllum asymmetricum Senowbari-Daryan and Rashidi, 2010; non Anchicodium magnum Endo, 1951 (= Eugonophyllum fide Konishi and Wray, 1961 and see later); non $A$. flexosum Endo, 1961c (= Neoanchicodium); non $A$. fascicularis Chuvashov, 1974 (= Richella Mamet and Roux in Mamet et al., 1987); non A. wensuensis Mu, 1985 (Calcipatera; see later); non $A$. expressum $\mathrm{Wu}$, 1991 (= Ivanovia).

Remarks. Anchicodium, Kansaphyllum, and Iranocodium are probably synonymous due to the great variability of the arrangements of the filaments in Anchicodium. On the other hand, Anchicodium is the oldest mound-building Pennsylvanian-Early Permian organism, for example, in New Mexico (Krainer et al., 2009 with references therein).

Occurrence. Rare and questionable in the Serpukhovian of Algeria (Lemosquet and Poncet, 1977; Sebbar and Lys, 1989; Sebbar and Mamet, 1996); Bashkirian of Spain and northern Africa (Vachard and Beckary, 1991; Sebbar and Mamet, 1996; with references therein). Relatively common and cosmopolitan (Tethys, Tibet, Japan and USA) from Moscovian to Early Permian. Rare up to the Guadalupian of Tunisia (Vachard et al., 1989a). Very rare in the Capitanian/Late Permian (e.g., with "Eugonophyllum" sp. sensu Vachard et al., 1993a, plate 2, figure 1, emended herein; and probably Anchicodium sindbadi; although this taxon is reworked in the Cretaceous according to Elliott (1970), and its real age poorly established).
Anchicodium japonicum Endo, 1953a

Figure 14.9, 14.10

*1953a Anchicodium japonicum Endo, p. 123-124, pl. 11, fig. 5, pl. 12, figs. 5-7.

1961d Anchicodium japonicum; Endo, p. 133, pl. 12, figs. 5-7.

?1968 Anchicodium magnum Endo; Flügel, p. 56 (no illustration).

?1968 Anchicodium plumosum Johnson; Flügel, p. 56 (no illustration).

1976 Anchicodium japonicum; Emberger, p. 79 (no illustration).

?1979 Anchicodium fukuyiense Endo and Horiguchi; Flügel, p. 572 (no illustration).

1980 Anchicodium japonicum; Flügel and FlügelKahler, p. 116-117, pl. 1, figs. 2, 3.

?1980 Eugonophyllum mulderi (Rácz); Flügel, p. 120-121, pl. 1, fig. 8.

?1995 Eugonophyllum sp.; Forke, p. 240, pl. 15/1.

?2004 Eugonophyllum mulderi; Flügel, pl. 58, fig. 5.

?2010 Anchicodium iranicum Senowbari-Daryan and Rashidi, p. 1011, pl. 1, figs. B, C, E-G, pl. 2, figs. A-D, pl. 4, figs. B, C, E, text-figs. 4-6.

v.2015 Calcipatera sp.; Lucas et al., fig. 21.18.

Description. Anchicodium with well-differentiated cortex and medulla (by this character, it differs from the coeval species $A$. sindbadi). The dimensions given by Flügel and Flügel-Kahler (1980) are the following: Thallus length $=1,100-7,800 \mu \mathrm{m}$; thallus width $=400-800 \mu \mathrm{m}$; cortical zone thickness $=$ 140-200 $\mu \mathrm{m}$; diameter of siphons $=30-40 \mu \mathrm{m}$.

Occurrence. Early Permian of Japan (Endo, 1953a, 1961d) and perhaps central Iran (as Anchicodium iranicum Senowbari-Daryan and Rashidi, 2010). In the Carnic Alps: Lower and Upper Pseudoschwagerina Limestone (Schulterkofel and Zweikofel formations), Grenzland Formation, Trogkofel Formation (Flügel, 1979); Forni Avoltri (Flügel, 1980); Seikofel (Flügel and Flügel-Kahler, 1980). This study: rare in the Zweikofel Fm (sample ZK67_A) and Zottachkopf Fm (samples TNA18_2_3; TKS 3_1_width $8 \mu \mathrm{m}$ ).

\section{Genus IVANOVIA Khvorova, 1946}

Type species. Ivanovia tenuissima Khvorova, 1946; by original designation.

Synonyms. ?Bolivianella Mamet, 1996.

Description. The recrystallized thalli are straight or curved, rarely sinuous or cupulliform, and composed of whitish, moderately to coarsely grained sparite. The shape of the preserved siphons is cylindrical to triangular, perpendicular to the wall and communicating with the external part of the thalli. They are uniform and homogeneous in 
shape and distance between them; hence, the microperforated zone appears very regular in thickness. The dark, micritic cement filling of the siphons is optically homogeneous.

Remarks. Ivanovia is principally a Middle-Late Pennsylvanian genus; it is interpreted as an important builder in the Paradox Basin and New Mexico, USA (Baars and Torres, 1991; Krainer et al., 2009). In the Permian, the best known species of Ivanovia is I. tebagaensis Vachard, GargouriRazgallah and Chaouachi, 1989a. Despite of several interpretations (Torres, 1995, 1999; Torres et al., 2003) of this species as coenocytic, cyathiform, and with an asexual reproduction, I. tebagaensis is most probably a junior synonym of $I$. triassica Torres, 2003. Furthemore, all the so-called Triassic Ivanovia described by Reid (1986) and Torres (2003) from Yukon Territory (Canada) could proceed from Permian olistolites which are relatively common in all the North Cordilleran areas (e.g., Skinner and Wilde, 1966; Rigaud, 2012). Finally, Ivanovia tebagaensis and I. triassica possibly correspond to a new taxon because they differ from true Ivanovia by the presence of hemispherical conceptacles only known in Eugonophyllum.

Furthermore, it is probable that Bolivianella is in reality represented by partly broken and/or dissolved thalli of Ivanovia and does not correspond to the reconstruction of Mamet (1996, text-figure $3 \mathrm{~A}, 3 \mathrm{~B})$.

Occurrence. Late Moscovian-Early Permian, cosmopolitan (Mamet et al., 1987; Mamet, 1991). Middle Permian (late Capitanian) of Tunisia (Vachard et al., 1989a). Triassic Ivanovia are questionable (see earlier).

\section{Ivanovia tenuissima Khvorova, 1946}

$$
\text { Figure 14.6-8 }
$$

1946 Ivanovia tenuissima Khvorova, p. 737-739, figs. $1,2$.

1963 Ivanovia tenuissima; Johnson, p. 24, pl. 20, figs. $1,2$.

1966b Ivanovia tenuissima; Rácz, p. 258-259, pl. 7, figs. 35-39.

.1964 Ivanovia tenuissima; Kochansky-Devidé, p. 513 (no illustration).

1976 Ivanovia tenuissima; Emberger, p. 84 (no illustration) (with four references).

?.1980 Ivanovia cf. tenuissima; Flügel, pl. 2, fig. 8.

.1980 Ivanovia cf. tenuissima; Flügel and FlügelKahler, p. 121, pl. 1, fig. 1.

1987 Ivanovia tenuissima; Mamet et al., p. 19-20, pl. 7, figs. 1-6, pl. 8, figs. 1-5 (with eight references in synonymy).

?.1991 Ivanovia sp.; Flügel et al., pl. 47, fig. 13.
?.1991 Pseudoepimastopora aff. ampullacea Elliott; Flügel et al., pl. 47, fig. 5 .

.1996 Ivanovia cf. tenuissima; Mamet, pl. 1, fig. 8.

?.2004 Ivanovia; Flügel, pl. 58, fig. 4 (= I. tebagaensis).

2004 Ivanovia tenuissima; Mamet and Villa, tabl. 3 p. 157 , p. 166 , fig. $12 a, j-n$ (with six additional references to Mamet et al., 1987).

v2012 Ivanovia tenuissima; Vachard et al., p. 235, 237, pl. 1, fig. 1.

v2013 Ivanovia tenuissima; Vachard et al., p. 7 (no illustration).

Description. The morphology and the dimensions are typical. Length of remain = several millimeters; width of remain $=500-1,000 \mu \mathrm{m}$; length of siphons (= "thickness of cortex" of the authors) $=50-150$ $\mu \mathrm{m}$; width of siphons $=10-30 \mu \mathrm{m}$; interval between siphons $=10-20 \mu \mathrm{m}$.

Remarks. Ivanovia tenuissima is generally well identified in the literature; nevertheless, it was designated as Permocalculus tenellus by Homann (1972, plate 1, figure 3, plate 3, figure $17 a-c$ ) and as Eugonophyllum by Kabanov et al., 2006 (plate 1 , figure 7).

Occurrence. Probably cosmopolitan from the Middle Pennsylvanian to the Late Cisuralian. In the Carnic Alps: Forni Avoltri (Flügel, 1979; Flügel and Flügel-Kahler, 1980); Upper Pseudoschwagerina Limestone (= Zweikofel and Zottachkopf formations) (Flügel, 1979); this study: Zweikofel $\mathrm{Fm}$ (samples GB49_2; GB76_3); Zottachkopf Fm (samples TNA2_1; TNC5_2); and Trogkofel Fm (sample TK26_2).

\section{Genus EUGONOPHYLLUM Konishi and Wray, 1961}

Type Species. Eugonophyllum johnsonii Konishi and Wray, 1961; by original designation.

Synonyms. Anchicodium (part.); Succodium (part.)

Description. Phylloid thallus with a peripheral layer of U-shaped subcortical siphons and neomicrosparitized cortical and medullar zones. Presence of more or less prominent, spherical, apical and lateral conceptacles.

Remarks. Concerning the putative synonymy of Eugonophyllum with Paradella Maslov, 1956a suggested, for example, by Kochansky-Devidé (1970b), Roux (1985) and Mamet et al. (1987), it is evident that, by its morphology and measurements, a specimen of Paradella adunca Maslov, 1956a (plate 84, figure 1; thin section $n^{\circ} 304-5 a$ at the Institute of Geological Sciences of the Russian Academy of Sciences) is similar to Eugonophyllum johnsonii. The conceptacles of Eugonophyllum- 
type are implicitly described (as conceptacles 2) and illustrated by Maslov (1956a) in P. adunca. On the other hand, $P$. arcuata Maslov, 1956a, could be another synonym; moreover, it comes from the same thin section $n^{\circ} 304-5 a$. However, Paradella is probably an invalid genus, because no holotype was designated by Maslov (1956a); moreover, it was never re-described in the Devonian.

Occurrence. Possible primitive forms in the Bashkirian (Vachard et al., 1989b, plate 3, figures 1-5, 7 , plate 4 , figure $1 \mathrm{~b}$; erroneously interpreted as recrystallized Archaeolithophyllum). Moscovian (Kashirian)-Capitanian, cosmopolitan: USA (New Mexico, Texas, Kansas, Oklahoma, Alabama, Colorado, Idaho), Canadian Arctic, Mexico (Sonora, Chiapas), Croatia, Serbia, Carnic Alps (Austria, Italy), northern Spain, Tunisia, Greece, Russia (Urals, Bashkortostan), Turkey, Tien Shan, Thailand, Vietnam and Japan.

Eugonophyllum magnum (Endo, 1951) emend. Konishi and Wray, 1961

Figure 11.4, Figure 14.11-12, Figure 15.1-12, Figure 16.1-3, 16.10-13,

Figure 17.3-4, Figure 20.4, Figure 26.16, Figure 29.9, Figure 30.11

*1951 Anchicodium magnum Endo, p. 125-126, pl. 11, figs. 3-5.

1954 Anchicodium magnum; Endo, p. 218, pl. 19, fig. 4.

1957 Anchicodium magnum; Endo, p. 292-293, pl. 41, fig. 4, pl. 42, fig. 2.

1957 Anchicodium magnum; Endo in Endo and Horiguchi, p. 175-176, pl. 15, fig. 3.

1961b Anchicodium magnum; Endo, pl. 11, fig. 5.

1961d Anchicodium magnum; Endo, p. 134-135, pl. 6, figs. 4-6.

1961 Eugonophyllum magnum; Konishi and Wray, p. 663 , pl. 75 , fig. 6 (with five references).

1963 Eugonophyllum magnum; Johnson, p. 127, pl. 18, fig. 7, pl. 74, fig. 3.

1964 Eugonophyllum?; Kochansky-Devidé, pl. 1, fig. 1.

$1965 \quad$ Neoanchicodium catenoides Endo; Ramovš and Kochansky-Devidé, p. 28-29 (= 346347), pl. 8, fig. 4.

.1966 Permocalculus cf. P. tenellus (Pia); Flügel, p. 16-17, pl. 1, fig. 3.

1966 Eugonophyllum johnsoni Konishi and Wray; Flügel, p. 20-21, pl. 3, figs. 3, 4.

?1968 Eugonophyllum johnsoni; Flügel, p. 55, 56 (no illustration).

?1968 Anchicodium magnum Endo; Flügel, p. 56 (no illustration).
1969 Eugonophyllum magnum; Güvenç, p. 448449, pl. 10, figs. 1-4.

p1970a Eugonophyllum magnum; Kochansky-Devidé, p. 210-211, 238-239, pl. 20, figs. 3, 5, 6 (non fig. 4 = E.? konishi; see later).

?1970a Anchicodium fukuyiense Endo and Horiguchi; Kochansky-Devidé, p. 211, 239, pl. 21, figs. 1, 2, 3?

1972 Anchicodium magnum; Homann, p. 175177, pl. 2, fig. 13.

1972 Eugonophyllum johnsoni; Homann, p. 177178, pl. 2, fig. 14.

1972 Succodium duisbergi Homann, p. 185-186, tabl. 19 p. 187 , pl. 3, fig. 17.

p1972 Neoanchicodium catenoides; Homann, p. 183-184, pl. 3, figs. 20, 21 (non fig. 22 = true Neoanchicodium catenoides).

.1972 Permocalculus cf. P. tenellus (Pia) Elliott; Homann, p. 161-163, pl. 1, fig. 3 (with 11 references in synonymy).

1976 Anchicodium magnum; Emberger, p. 80 (no illustration) (with five references).

1977 Eugonophyllum johnsonii; Flügel, tabl. 2 p. 320, pl. 1, fig. 4.

non 1977 Anchicodium magnum; Lemosquet and Poncet, p. 337, pl. 8, figs. 1-6, pl. 9, fig. 1 (= another species of Anchicodium).

?1978 Eugonophyllum johnsoni; Kulik, p. 184-185, pl. 1, figs. 1-3.

?1978 Eugonophyllum johnsoni; Kochansky-Devidé and Ramovš, p. 237 (no illustration).

?1979 Anchicodium magnum Endo; Flügel, p. 572 (no illustration).

?1979 Succodium duisbergi; Flügel, p. 572 (no illustration).

1980 Eugonophyllum johnsoni; Flügel, pl. 7, figs. 4, 5, pl. 12, fig. 5.

p1980 Eugonophyllum; Flügel, pl. 8, fig. 1 (bottom), pl. 9, figs. 1,4 (non pl. 10, fig. $1=$ Neoanchicodium catenoides).

1980 Archaeolithophyllum sp.; Flügel and FlügelKahler, pl. 10, figs. 2, 7, pl. 13, fig. 6.

1980 Eugonophyllum johnsoni; Flügel, pl. 7, fig. 5, pl. 8, fig. 1, pl. 9, figs. 1, 4, pl. 10, fig. 1, pl. 12, fig. 5.

1980 Eugonophyllum johnsoni; Flügel and FlügelKahler, p. 117-118, 120, pl. 1, figs. 4-6

1982 Atractyliopsis sp.; Mu, p. 219, pl. 5, fig. 1.

1983 Succodium duisbergi; Bassoullet et al., p. 571-572, pl. 15, fig. 8-10.

1985 Eugonophyllum magnum; Mu, pl. 15, figs. 24, 8.

1987 Phylloid algae; Flügel, pl. 9, fig. 3.

1989 Neoanchicodium catenoides; Vachard in Fontaine and Gafoer, pl. 56, figs. 1-3, 5. 

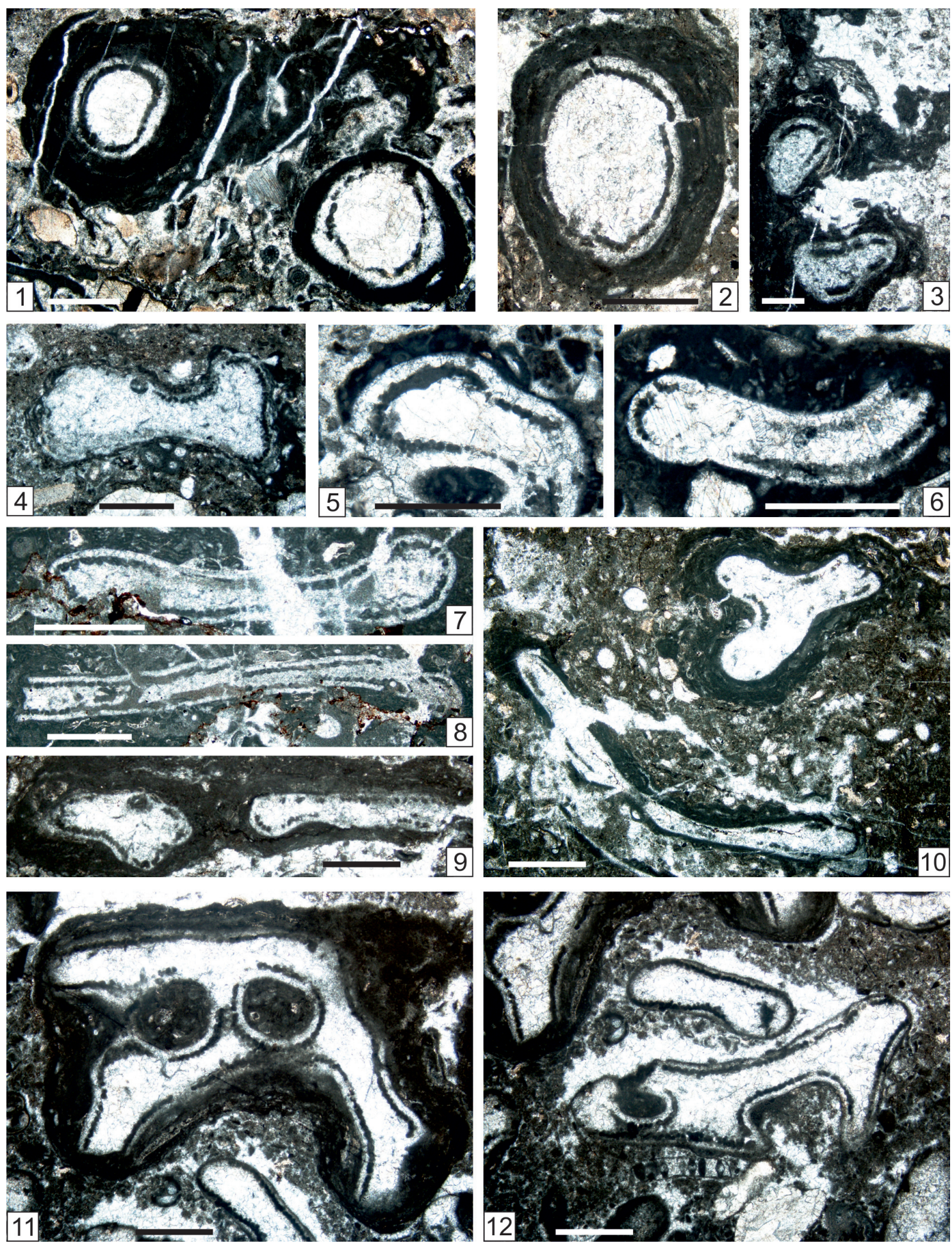

FIGURE 15. 1-12. Eugonophyllum magnum (Endo, 1951) emend. Konishi and Wray, 1961. 1. Two transverse sections as nuclei of oncoids. Sample TKS1_1b. 2. Transverse section as nucleus of an oncoid. Sample TKS3_2. 3. Two oblique sections with a Tetrataxis sp. Sample Z12B_3. 4. Longitudinal section showing a conceptacle. Sample TKS6_1. 5. Longitudinal section with a loop. Sample TKS13_2. 6. Longitudinal section as nucleus of an oncoid. Sample TKS13_3. 7. Longitudinal section. Sample TKS14_1a. 8. Longitudinal section. Sample TSK14_1b. 9. Two longitudinal sections (one with a conceptacle). Sample Z6B_1. 10. Two longitudinal sections (one with a bifurcation of the thallus). Sample TKW6_1b. 11. Typical longitudinal section (with two loops). Sample Z6B_3a. 12. One typical section (center) with four other ones. Sample Z6B_3b. Scale bars: $0.5 \mu \mathrm{m}$ (Figure 15.3); all others $=1 \mu \mathrm{m}$. 
non 1989 Anchicodium magnum; Sebbar and Lys, pl. 1, fig. 3 (= another species of Anchicodium).

.1991

.1991

?1991

1995

.2004

?2007

Neoanchicodium; Riding and Guo, fig. 13.

Eugonophyllum; Riding and Guo, fig. 14.

Pseudoepimastopora aff. ampullacea Elliott; Flügel et al., pl. 47, fig. 5 (or Eugonophyllum?).

Neoanchicodium sp.; Forke, p. 240, pl. 15, fig. 2.

Eugonophyllum; Flügel, pl. 58, fig. 3. figs. $23.3,23.4,149.3,149.4$.
Description. Network of blades loosely anastomosed and fragments partly ramified. Utricles well described by Homann (1972). $L=2,200-5,000 \mu \mathrm{m}$; $w=360-1,700-(2,200) \mu \mathrm{m}$; thickness of cortical layer $=50-130 \mu \mathrm{m}$; utricle diameter $=(7)-10-20-$ (50) $\mu \mathrm{m}$; diameter of conceptacles $=300 \mu \mathrm{m}$; thallus loop diameter $=600-1,150 \mu \mathrm{m}$.

Remarks. Our material suggests that a morphological (and perhaps phylogenetic) transition exists between Eugonophyllum and Neoanchicodium, by a coalescence of the blades forming the thalli, and a deepening within the thallus of the utricular cortical zone (see e.g., the material present in the interval from TKS11 to TKS14 or in Z9_2/Z9_3).

Occurrence. Early-Middle Permian of Japan (Endo, 1961d); Artinskian of Sumatra (Vachard in Fontaine and Gafoer, 1989); Xizang (Mu, 1982); Xinjiang (Mu, 1985); Artinskian of Slovenia (Kochansky-Devidé, 1970a). In the Carnic Alps and Velebit in Croatia: Upper Pseudoschwagerina Limestone (Zottachkopf Fm) of Zottach-Kopf (Homann, 1972); Forni Avoltri (Flügel, 1980); lithoclasts of the Tarviser Brekzie (Flügel and FlügelKahler, 1980); and in this study: Grenzland Fm (sample GB19_1b); Zweikofel Fm (samples GB132_3; GB136_2; GB154_6; ZK95a_7; ZK99a_A; ZK187_F; ZK188_1_A; ZK200_1; ZK201_A; ZK204_A); Zottachkopf Fm (TKS1_1b; TKS2_5; TKS3_2; TKS4_2; TKS4_3; TKS6_1; TKS11_2; TKS̄13_2; TKS13_3; TKS14_1a; TKS14_1b; TKW2_1; TKW5_2a; TKW5_2b; TKW6_1a; TKW6_1b; TKW6B_3; TKW10_4; Z2_1; Z6B_1; Z6B__3a; Z6B_3b; Z7_1; Z9_2; Z9B_2; Z12B_3); basal Trogkofel Fm (samples TKS11_2; TKS 14_1a; TKS 14_1b; TKS 16_1; TM7_3); and Trogkofel Fm (samples TK47_1; TK48_2; TK51A_2; TK52_1).

\section{Eugonophyllum? konishi Kulik, 1978}

Figure 17.1, 17.2

*1978 Eugonophyllum konishi Kulik, p. 186, pl. 2, figs. $1-3$. p1970a Eugonophyllum magnum (Endo); Kochansky-Devidé, p. 210, 238-239, pl. 20, fig. 3 (only, non figs. 1, 5, 6 = true Eugonophyllum magnum).

1995 Eugonophyllum sp.; Forke, pl. 15, fig. 1.

? 2011 Eugonophyllum sp.; Vachard and Moix, pl. 3 fig. 14.

Description. Phylloid thallus with a unilateral, peripheral layer of acrophore, bifurcated, rarely trifurcated cortical siphons, perpendicular to the outer surfaces, and with a neomicrosparitized, narrow medullar zone. Conceptacles of Eugonophyllum johnsoni-type. $\mathrm{L}=2,300-4,400 \mu \mathrm{m} ; \mathrm{w}=420-$ $700 \mu \mathrm{m}$; thickness of cortical layer $=150-200 \mu \mathrm{m}$; utricle diameter $=50-60 \mu \mathrm{m}$; diameter of conceptacles $=300-500 \mu \mathrm{m}$.

Remarks. Either this species corresponds to exceptionally, well-preserved cortical siphons, or it corresponds to a different, unpublished genus.

Occurrence. ?Late Pennsylvanian of Turkey (Vachard and Moix, 2011). Early Permian of the Urals (Kulik, 1978). Artinskian of Slovenia (Kochansky-Devidé, 1970a). In the Carnic Alps (this study): basal Trogkofel Fm (sample TM6A_1); and Trogkofel Fm (sample TK49_2).

\section{Genus NEOANCHICODIUM Endo in Endo and Kanuma, 1954}

Type species. Neoanchicodium catenoides Endo in Endo and Kanuma, 1954; by original designation.

Description. Thallus composed of several anastomosed blades forming various loops. Cortical and medullar zone sparitized. Medullar zone neosparitized generally inconspicuous. Subcortical zone with large connected utricules forming a peripheric to central, round catena in transverse section. Conceptacles unknown.

Other species. ?Anchicodium flexosum Endo, 1961c (see above). Neoanchicodium paradoxa Kulik, 1978; N. pseudoarticulatum Kulik, 1978; N. shichanense Kulik, 1978.

Occurrence. Kasimovian-Sakmarian (Chuvashov et al., 1993). Asselian-Artinskian of Japan (Smegai Formation), New Mexico, Canadian Arctic, Austria (Auernig Fm-Trogkofel Fm), Slovenia, Montenegro, Bashkortostan (Russia) and Turkey (Roux, 1985). Late Sakmarian of Sumatra (Fontaine and Vachard, 1984, re-dated here). Kubergandian of Thailand.

\section{Neoanchicodium catenoides Endo in Endo and Kanuma, 1954}

Figure 16.4-9, Figure 18.6, Figure 27.7-8 

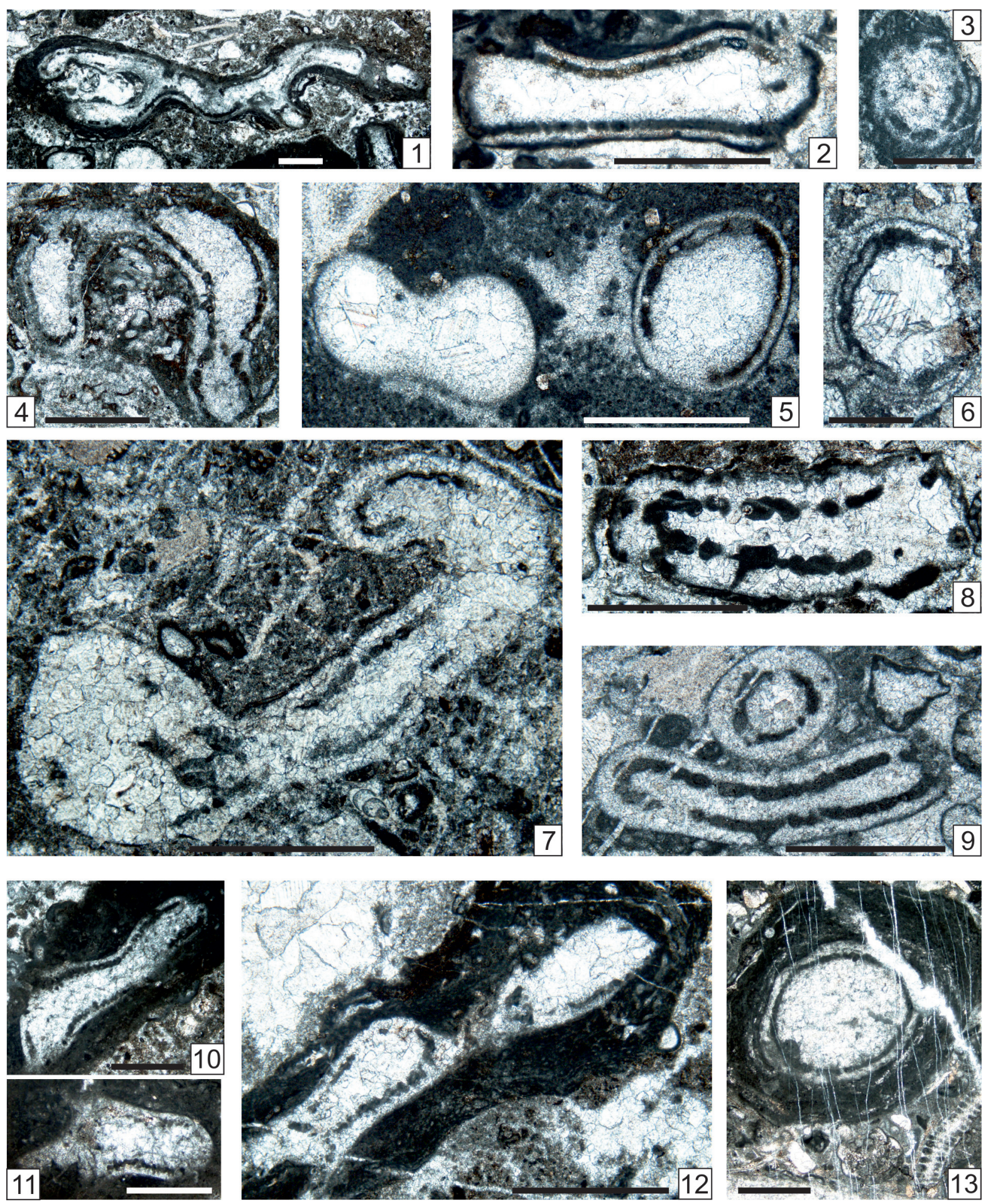

FIGURE 16. 1-3, 10-13. Eugonophyllum magnum (Endo, 1951) emend. Konishi and Wray, 1961. 1. Typical, ramified axial section. Sample. Z9B_2a. 2. Longitudinal section. Sample TK51A_2. 3. Transverse section. Sample GBT3_1. 10. Longitudinal section. Sample Z9_2. 11. Longitudinal section. Sample Z9_2. 12. Longitudinal section encrusted with girvanellaceans and a tuberitinid (center, right). Sample TKW10_4. 13. Transverse section with Globuliferoporella sp. (bottom, right). Sample TKS4_3. 4-9. Neoanchicodium catenoides Endo in Endo and Kanuma, 1954. 4. Longitudinal section. Sample TKW9_2. 5. Neomicrosparitized transverse section (left) and more typical transverse section (right). Sample TK_64_2. 6. Transverse section. Sample GBT4_3. 7. Longitudinal section. Sample TKW9_5. 8. Longitudinal section. Sample TKW9B_2. 9. Transverse section (top, center) and longitudinal section (bottom). Sample TNC2_4. Scale bars: $0.5 \mu \mathrm{m}$ (Figures 16.4, 16.6); all others $=1 \mu \mathrm{m}$. 
*1954 Neoanchicodium catenoides Endo in Endo and Kanuma, p. 202-203, pl. 15, figs. 7-10.

1961b Neoanchicodium catenoides Endo, p. 30, pl. 11, fig. 10.

1961d Neoanchicodium catenoides Endo, p. 108, pl. 18, fig. 4, pl. 19, figs. 1, 2.

1962 Neoanchicodium catenoides; KochanskyDevidé and Milanović, p. 219, pl. 8, figs. 3, 4.

1963 Neoanchicodium catenoides; Johnson, p. 130, pl. 71, fig. 9 .

1965 Neoanchicodium catenoides; Herak, p. 210, 214 (no illustration).

1966 Neoanchicodium catenoides; Flügel, p. 2122, pl. 3, figs. 1, 2.

1968 Neoanchicodium catenoides; Flügel p. 55, 56 (no illustration).

1969 Neoanchicodium catenoides; Endo, p. 44, pl. 11 , figs. $1-5$.

1970a Neoanchicodium catenoides; KochanskyDevidé, p. 211-212, 239-240, pl. 21, figs. 46 (with three references in synonymy).

p1972 Neoanchicodium catenoides; Homann, p. 183-184, pl. 3, fig. 22 (non figs. 20, $21=$ Eugonophyllum magnum).

1978 Neoanchicodium catenoides; Kulik, p. 187188, pl. 2, fig. 6.

1979 Neoanchicodium catenoides; Flügel, p. 572, pl. 1, fig. 9.

p1980 Eugonophyllum; Flügel, pl. 10, fig. 1 (non pl. 8, fig. 1, nec pl. 9, figs. 1, 4 = Eugonophyllum magnum).

$1980 \quad$ Neoanchicodium catenoides; Flügel and Flügel-Kahler, p. 122-123, pl. 1, fig. 7 (with 11 references in synonymy).

1982 Neoanchicodium catenoides; Mu, p. 217218, pl. 3, figs. $5,8$.

1985 Neoanchicodium catenoides; Roux, pl. 2, fig. 10.

1987 Neoanchicodium catenoides; Mamet et al., p. 18-19, pl. 6, figs. 9-15, pl. 7, figs. 7, 8.

non 1989 Neoanchicodium catenoides; Vachard in Fontaine and Gafoer, pl. 56, figs. 1-3, 5 (see earlier: Eugonophyllum magnum).

v2003a Neoanchicodium catenoides; Krainer et al., table 1 p. 18 , p. 19 , pl. 6 , fig. 31 , pl. 7 , fig. 12 , pl. 8, fig. 19.

2004 Neoanchicodium; Flügel, pl. 58, fig. 2, pl. 100, figs. 1, 2.

v2011 Neoanchicodium catenoides; Vachard and Moix, p. 157 (no illustration).

v?.2015 Neoanchicodium cf. catenoides; Lucas et al., fig. 40.1 .

v.2017a Neoanchicodium catenoides; Krainer et al., p. 20 , pl. 43 , figs. 10,11 , pl. 44 , figs. 5,7 , pl. 47, figs. 2, 4.
Description. Dimensions of thalli $=2,000-5,000 \mathrm{x}$ 1,000-3,200 $\mu \mathrm{m}$; utricle diameter $=10-20$ (30) $\mu \mathrm{m}$; distance utricles-periphery $=150-400 \mu \mathrm{m}$.

Occurrence. Early Permian of Japan (Endo and Kanuma, 1954), Montenegro (Kochansky-Devidé and Milanović, 1962); Dinarides (Herak, 1965: Sakmarian-Kungurian); southwestern Turkey (Vachard and Moix, 2011: Sakmarian/early Artinskian); Tibet (Mu, 1982); Canadian Arctic (Roux, 1985; Mamet et al., 1987), and New Mexico (Lucas et al., 2015; Krainer et al., 2017a). In the Carnic Alps, FO (first occurrence) in the Orenburgian of Kronalpe (Vachard and Krainer, 2001a), and present in the whole Rattendorf Group and Trogkofel Formation (Flügel, 1968, 1979; Vachard and Krainer, 2001b); Seikofel, Forni Avoltri, and Goggauer-Kalk (Flügel and Flügel-Kahler, 1980; Flügel, 2004). This study: Zweikofel Fm (samples ZK198_A; ZK199_A; ZK201_10); Zottachkopf Fm (samples TKS1_1a; TKS2_1; TKS4_3; TKS12_1; TKW9_2; TKW' 5_5; TKW9_4a; TKW9B_2; TNC2_4; Z6_3; Z9̄2; Z9B_2a; Z9B_3; Z11_2; Z12_2; Z12B_3; Z14_1); and Trogkofel Fm (samples GBT3_1; GBT4_2; GBT4_3; TK51A_2; TK64_2).

Genus CALCIPATERA Torres, West and Sawin, 1992 emend. herein

Type species. Calcipatera cottonwoodensis Torres, West and Sawin, 1992; by original designation.

Synonyms. Anchicodium sensu Laporte (1962) (see Torres and Baars, 1992) and Anchicodium sensu Mu (1985); Halimeda sensu Poncet (1989).

Emended diagnosis. Phylloid thallus with a bilateral, peripheral layer of acrophore, trifurcated cortical siphons (S1, S2, S3), perpendicular to the outer surfaces and with a neomicrosparitized, narrow medullar zone. Conceptacles not observed.

Remarks. Late Capitanian Halimeda soltanensis Poncet, 1989 of Bir Soltane (Tunisia) does not belong to Halimeda, but are probably part of Calcipatera, due to the trifurcated utricles of the cortical zone. Similarly, Anchicodium wensuensis $\mathrm{Mu}$, 1985 does not belong to Anchicodium but to Calcipatera.

Occurrence. Late Pennsylvanian of the USA (Torres et al., 1992 with references therein). Early Permian of South China (Mu, 1985). Late Cisuralian of the Carnic Alps (this study). ?Kubergandian of Oman (Vachard et al., 2001a). Late Capitanian of Tunisia (Poncet, 1989; re-interpreted here).

Calcipatera schoenlaubi n. sp.

Figure 17.5-6, 17.8-11, Figure 20.1 
?1980 Epimastopora cf. kanumai Endo; Flügel and Flügel-Kahler, p. 149, pl. 6, fig. 7.

?v 2001a Kansaphyllum or "Halimeda"; Vachard et al., fig. 14.10.

?v.2015 Calcipatera sp.; Lucas et al., fig. 21.18.

Etymology. Dedicated to Hans-Peter Schönlaub, for his work in the Carnic Alps.

Holotype. Institute of Geology, University of Innsbruck, Cat. Nrs. TNA16 (thin section); Figure 17.8; sample TNA16_1_1.

Paratypes. Institute of Geology, University of Innsbruck, Cat. Nrs. TNA 16, TNA 18, TM 7, TK 16 and TK 53 (thin sections); Figures 17.5, 17.6, 17.9-11 and 20.1.

Type locality. Trogkofel Massif.

Type level. Zottachkopf Fm.

Diagnosis. A species of Calcipatera characterized by three orders of thin cortical siphons, and short, poorly preserved medullar siphons. No conceptacles are known.

Description. Thallus length $=2,600-7,000 \mu \mathrm{m}$; thallus width $=(370)-500-830 \mu \mathrm{m}$; cortical zone thickness $=250-400 \mu \mathrm{m}$; diameter of cortical siphons (S1, S2 and S3, from medulla to periphery): $\mathrm{S} 1=50-70 \mu \mathrm{m} ; \mathrm{S} 2=30-40 \mu \mathrm{m}$; and $\mathrm{S} 3=$ 15-25 $\mu \mathrm{m}$.

Material. 10 specimens.

Repository of the types. Institute of Geology, University of Innsbruck (Austria).

Comparison. The new species differs from $C$. wensuensis, which is similar, by a little larger test and different dimensions of the three orders of cortical siphons: S1, S2 and S3 (in C. wensuensis: $\mathrm{S} 1=60-100 \mu \mathrm{m} ; \mathrm{S} 2=40-80 \mu \mathrm{m} ; \mathrm{S} 3=20-50 \mu \mathrm{m})$. It differs from $C$. cottonwoodensis by thinner and more elongate cortical siphons and shorter medullar siphons, and from $C$. soltanensis by less numerous cortical siphons and poorly preserved medullar siphons.

Occurrence. ?Kubergandian of Oman (Vachard et al., 2001a); ?Permian of New Mexico (Lucas et al., 2015). In the Carnic Alps: perhaps in Forni Avoltri (Flügel and Flügel-Kahler, 1980; and this study: Zweikofel Fm (samples ZK67_A; ZK85_A); Zottachkopf Fm (TNA16_1_1; TNA16_2_2; TNA16_2; TNA16_2_4a; TNA 16_-2_5; TNA $\overline{1} 18 \_2$ 3); basal Trogkofel Fm (samples TM7_3; TK_16_2); Trogkofel Fm (sample TK53_1).

?Family GYMNOCODIACEAE Elliott, 1955

Remarks. The gymnocodiaceans are relatively well-known algae, based on the work of Pia (1937); Elliott (1955); Kochansky-Devidé and Slišković (1969); Termier et al. (1977); Vachard (1980); Roux (1985); Roux and Deloffre (1990); Bucur (1994); and Vachard et al. (2015). The saga of the genus Gymnocodium (Pia, 1920) Elliott, 1955 is well known (Elliott, 1955; Roux and Deloffre, 1990), and mainly punctated by the successive interpretations of Pia (1912, 1920, 1927 and 1937). Finally, this alga was assigned by this latter author to the chaetangiacean red algae and compared with the extant genus Galaxaura Lamouroux, 1812. For a long time considered as red algae (Pia, 1937; Elliott, 1955; Termier et al., 1977), the Gymnocodiaceae are currently assigned to the green algae (Chuvashov et al., 1987; Bucur, 1994; Vachard et al., 2015).

Composition. After the work of Pia, Elliott (1955) created the extinct family Gymnocodiaceae with Gymnocodium to Permocalculus Elliott, 1955. More recently, these algae were revised by Güvenç (1966); Kochansky-Devidé and Slišković (1969); Roux and Deloffre (1990), Roux (1991) and Deloffre (1992). In Roux and Deloffre (1990) and Roux (1991), the Gymnocodiaceae encompassed six genera and subgenera: Gymnocodium; Permocalculus (Permocalculus); Permocalculus (Pyrulites) Mu, 1981; Abatea Senowbari-Daryan and Schäfer, 1980; Nanjinophycus $\mathrm{Mu}$ and Riding, 1983; and Oligoplagia (Herak, 1944) Flügel, 1971b. The genera Dzhulfanella Kordé, 1965; Tauridium Güvenç, 1966, Aphroditicodium Elliott, 1970a; and Asterocalculus Sokač and Grgasović, 1998 could also belong to the Gymnocodiaceae. Dzhulfanella is a morphotype of Permocalculus, according to Roux (1991), as such as Tauridium. Furthermore, Thailandoporella Endo, 1969, and Siamporidium Endo, 1969, are probably other taphotaxa corresponding to Permocalculus (Vachard et al., 2005). On the other hand, Succodium Konishi, 1954b, presents many similarities with Permocalculus, but also with Nanjinophycus Mu and Riding, 1983. This interpretation of Succodium and Nanjinophycus, as two stages and not two genera, might explain that they are infrequently mentioned in the literature because its identification depends on their stages of preservation. The main species of Permocalculus are: $P$. gracilis (Pia, 1937); P. plumosus Elliott, 1955; $P$. digitatus Elliott, 1955; $P$. solidus (Pia, 1937); and $P$. tenellus (Pia, 1937). It is likely that the other species described by Pia, Elliott, Johnson and Kordé are synonymous (Roux, 1991). Despite the Lopingian crisis of the carbonates (Weidlich, 2002), Permocalculus and Gymnocodium still constitute many thick bioaccumulations during the Late Permian. Then, Gymnocodium disappears at the PTB (Permian-Triassic Boundary), whereas Permocal- 

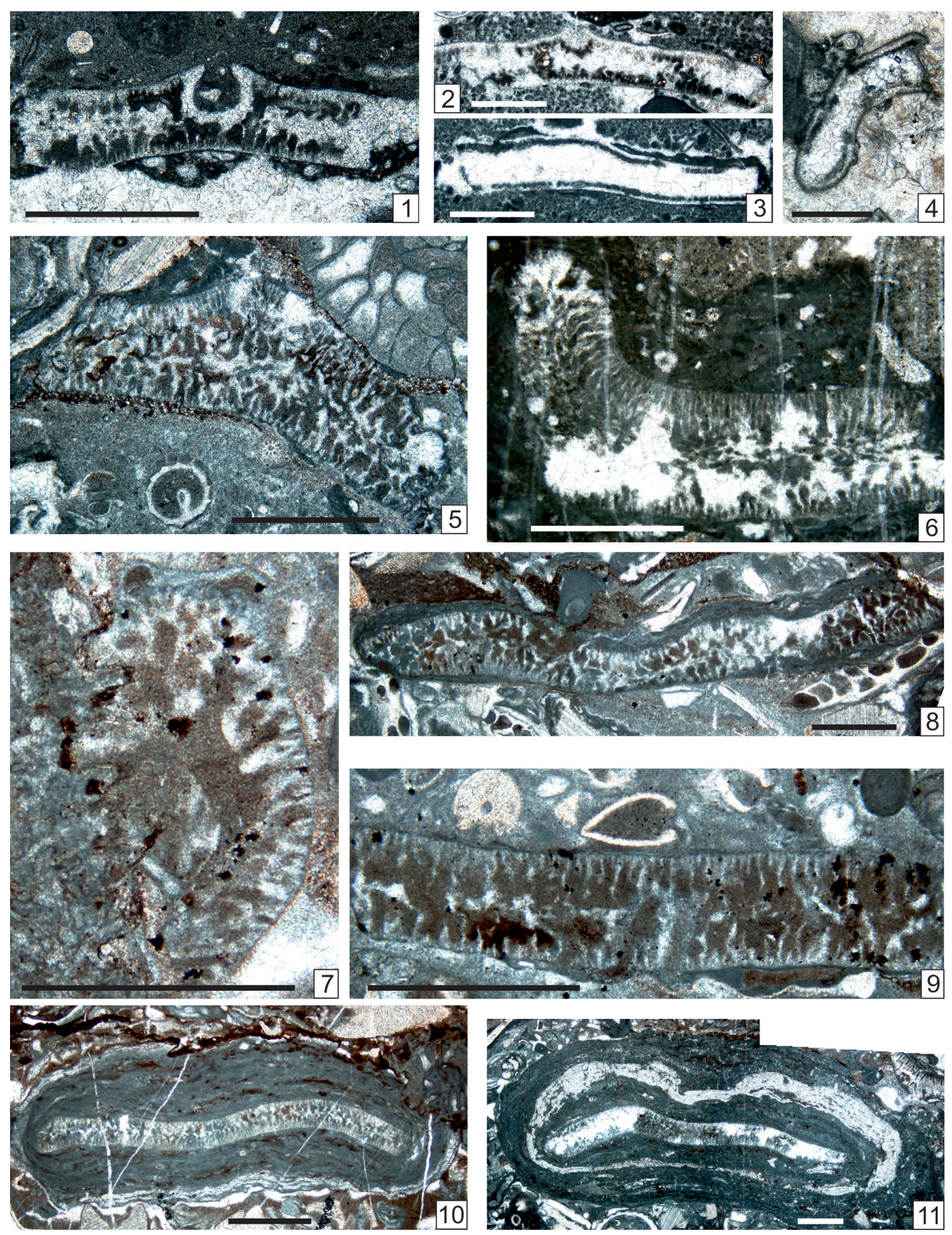

FIGURE 17. 1, 2. Eugonophyllum? konishi Kulik, 1978. Two fertile longitudinal sections. 1. Sample TM6A_1. 2. Sample TK49_2. 3, 4. Eugonophyllum magnum (Endo, 1951) emend. Konishi and Wray, 1961. Two longitudinal sections. 3. Sample. TK47_1. 4. Sample TK52_1. 5, 6, 8-11. Calcipatera schoenlaubi n. sp. Six subaxial sections. 8. Holotype. Sample TNA16_1_1. 6. Paratype. Sample ZK85A. 9. Paratype. Sample TK16_2_2. 10. As nucleus of an girvanellacean oncoid. Paratype. Sample TNA18_2_3. 11. As nucleus of an oncoid with girvanellacean and claracrustacean. Paratype. Sample TNA16_2_4. 7. Nanjinophycus? sp. Broken longitudinal section. Sample TNA16_2_1. Scale bar 1 $\mu \mathrm{m}$. 
culus is still encountered in the Mesozoic (Elliott, 1955; Granier et al., 2017).

Occurrence. ?Late Pennsylvanian. Cisuralian-Triassic. Lazarus effect in the Cretaceous.

Genus NANJINOPHYCUS Mu and Riding, 1983

Synonyms. Succodium (part.).

Type species. Nanjinophycus ovatus Mu and Riding, 1983; by original designation.

Description. Thalli segmented. The segments are spherical, ovoid or barrel-like. Some specimens with well-preserved calcified medullar zone are known. The distal parts of the cortical filaments are vesiculifer, and connected to the surface with two to four terminal branchlets. Fertile specimens are unknown.

Occurrence. Early Permian of South China; Permian of Viet Nam (Mu and Riding, 1983); ?Capitanian of Cambodia (Nguyen Duc Tien, 1986a, pl. 9, figs. 1, 2). Questionably present in the Artinskian of the Carnic Alps (this study).

Nanjinophycus? sp.

Figure 17.7, Figure 22.4?

?1970a Permocalculus aff. kanmerai (Konishi); Kochansky-Devidé, p. 219, 243-244, pl. 26, figs. 1, 2.

1972 Gymnocodium cf. gracile Kordé; Homann, p. 160-161, pl. 1, fig. 8.

?.1979 Gymnocodium cf. bellerophontis Rothpletz; Flügel, p. 572 (no illustration).

?1979 Permocalculus sp.; Flügel, p. 572 (no illustration).

?1989 Permocalculus tenellus Pia; Vachard in Fontaine and Gafoer, pl. 8, figs. 4, 5, pl. 9, fig. 2.

$2004 \quad$ Permocalculus; Flügel, pl. 57, fig. 7.

Description. $L=1,400-2,000 \mu \mathrm{m} ; \mathrm{w}=$ approximately $1,000-1,500 \mu \mathrm{m}$; diameter of laterals $L 1=$ $20-50 \mu \mathrm{m}$; diameter of laterals $L 2$ and $L 3=10-20$ $\mu \mathrm{m}$.

Occurrence. LP, UP, TK; i.e., Zweikofel and Zottachkopf formations (Flügel, 1979). In this study: Zweikofel Fm (sample GB76_3); and Zottachkopf Fm (samples TNA16_1_2; TNA_16_2_1; TNA16_1_2; TNA16_2_1).

Class CHLOROPHYCEAE Kützing, 1843

Order DASYCLADALES Pascher, 1931

Family SELETONELLACEAE Kordé, 1950 nom. translat. Kordé, 1973 emend.

Bassoullet, Bernier, Deloffre, Génot, Jaffrezo and Vachard, 1979

Description. Aspondyl Dasycladales.

Occurrence. This family corresponds to the aspondyl (i.e., random and without verticils) arrangements of the laterals of dasycladales (Bassoullet et al., 1979; Roux, 1985; Deloffre, 1987, 1988); its representatives are common from the Ordovician to the Triassic (and were mentioned from the Cambrian to the Early Cretaceous; see Deloffre, 1988, table 3).

Tribe ANTHRACOPORELLEAE $\mathrm{n}$. trib.

Diagnosis. Aspondyl Dasycladales rarely bifurcated, with simple or bifurcated laterals, and a thin calcified, perforate cortex covering the extremities of the laterals.

Composition. Anthracoporella Pia, 1920; Zaporella Rácz, 1966a; Givetianella Mamet and Préat, 1982; Couvinianella Mamet and Préat, 1992 (which probably corresponds to the Devonian Anthracoporella of the literature) (Shuysky, 1973; Saltovskaya, 1984b; Shuysky and Patrunov, 1991; Mamet and Préat, 1992); Favoporella Wu, 1991; ?Iskanderkulia Saltovskaya, 1984b; ?Mellporella Rácz, 1966a.

Remarks. True Dasycladales appear in Middle Ordovician. The previous, Cambrian forms (including Seletonellaceae sensu stricto) are very disputable, as well as the vermiporellaceans (which were also assigned to the Ulotrichales by Kozlowski and Kazmierczak, 1968; Vachard et al., 1989b; and Pille, 2008). Anthracoporella, which for a long time was admitted as a paragon of the Paleozoic Dasycladales (Pia, 1920; Emberger, 1976; Mamet, 1991; De Castro, 1997; Vachard et al., 2001a), even if it was previously compared to Vermiporella (Pia, 1920; Endo 1961b), is currently considered as a disputable dasyclad (De Castro, 2002; Granier, 2012). The discovery of endospores, morphologically similar to those of evolved dasycladales (e.g., some Diplopora illustrated by Pia, 1920, Elliott, 1972, Flügel, 2004; Triploporella described by Barattolo, 1982, 1983 and De Castro, 1982; and Acicularia? of De Castro and Sirna, 1996), in our opinion, might allow to confirm the assignment of Anthracoporella to the dasycladales.

Occurrence. Middle Devonian-Middle Permian; the genera of this tribe are either cosmopolitan or only present in the Tethyan-Uralian realm.

Genus ANTHRACOPORELLA Pia, 1920

Type species. Anthracoporella spectabilis $\mathrm{Pia}$, 1920; by original designation.

Synonyms. Epimastopora (part.); Anchicodium (part.); Paraepimastopora (part.) (see Vachard et al., 2001a).

Description. Thallus large, cylindrical, ramified. Laterals numerous, aspondyl, acrophore, simple, rarely bifurcated. An outermost, thin calcified cuti- 
cle covers the pores of the laterals; this cuticle is finely perforated. Fertile endospore specimens have been discovered in this study.

Other species. See Vachard in Vachard and Montenat (1981, p. 34-35); Saltovskaya (1984b, p. 142) and Vachard in Vachard et al. (2001a, p. 384). Remarks. Many references to $A$. spectabilis are in reality assignable to $A$. vicina or to another unpublished species of Anthracoporella, following the references listed herein (see later).

Occurrence. Questionable in the late Bashkirian of Spain (Rácz, 1966a), early Moscovian of Croatia (Kochansky-Devidé, 1970b) and France (Delvolvé et al., 1987), late Moscovian of Spain (Rácz, 1966b), and latest Moscovian of New Mexico (Lucas et al., 2015, figure 21.D, 21.F; for a taxon that most probably belongs to Paraepimastopora). The acme period, and probably cosmopolitan distribution, is likely Kasimovian (Vachard and Moix, 2013) to Artinskian (this study), rather than early Moscovian-Sakmarian according to Chuvashov et al. (1993). Rare in the Capitanian of Croatia, Slovenia, Afghanistan, Oman, Malaysia (Vachard et al., 2001) and South China (Lai et al., 2008). In the Carnic Alps: in the Rattendorf Group and Trogkofel Formation (Flügel, 1979); Forni Avoltri (reworked); Hüttenkofel, Gzhelian (Flügel, 2004); Karawanken Mountains (Pia, 1920; Flügel and Flügel-Kahler, 1980).

Anthracoporella spectabilis Pia, 1920 emend. De Castro, 2002

Figure 18.1, Figure 22.1

*1920 Anthracoporella spectabilis Pia, p. 15-18, text-fig. 3 p. 16, pl. 1, figs. 7-11.

1937 Anthracoporella spectabilis Pia, p. 809-810 (no illustration).

1954a Macroporella (?) sp., gen. et sp. nov. indet. (sic); Konishi, p. 6-7, pl. 2, fig. 18 (sic fig. 16 in the text).

1960 Anthracoporella spectabilis; Kochansky and Herak, p. 66-69, pl. 1, fig. 6, pl. 2, figs. 1-6 (with six references in synonymy).

1962 Anthracoporella spectabilis; Kochansky-Devidé and Milanović, p. 216, pl. 6, fig. 1.

p1963 Anthracoporella spectabilis; Johnson, pl. 8, figs. $1-3$, pl. 9, fig. 3 (non figs. 1, $2=A$. vicina), pl. 49, figs. 1-6.

p1963 Anthracoporella spectabilis; Maslov et al., text-fig. 20a, 20b (non pl. 15, figs. 1, $2=A$. vicina).

1964 Anthracoporella spectabilis; Bebout and Coogan, p. 1094, pl. 169, figs. 1-4.

1964 Anthracoporella spectabilis; Kochansky-Devidé, p. 515, 516 (no illustration). ?1966a Anthracoporella spectabilis; Rácz, p. 92-93, pl. 5, figs. 4-7 (with six references; another species and/or another genus?).

1966 Anthracoporella spectabilis; Chanton, tabl. 1 p. 404 (no illustration).

?1968b Epimastopora malaysiana Elliott, p. 491493, pl. 93, figs. 3, 4.

1970a Anthracoporella spectabilis; Kochansky-Devidé, p. 212, pl. 22, fig. 3.

1974 Anthracoporella spectabilis; Chuvashov, p. 20-21, pl. 6, figs. 1-6.

1976 Anthracoporella spectabilis; Emberger, p. 19, 21 (no illustration) (with 46 references).

?1982 Zaporella baxoensis Mu, p. 230-231, pl. 9, figs. 1-5.

non 1985 Anthracoporella spectabilis; Mu, pl. 14, figs. 7, 8 (7 = Anthracoporella? sp. ; $8=$ A. vicina $)$.

?1985 Epimastopora tomurica Mu, p. 145, pl. 15, fig. 9.

?1987 Anthracoporella spectabilis; Delvolvé et al., p. 544,545 , pl. 1 , fig. 5 (perhaps another species).

1997 Anthracoporella spectabilis; De Castro, pl. 1, figs. 1, 2, pl. 2, figs. 1-12, pl. 3, figs. 1-5.

1997a Anthracoporella; Samankassou, fig. 7.3.

1997 Anthracoporella spectabilis; Sokač et al., p. 145 (no illustration).

1998 Anthracoporella; Samankassou, figs. 5, 6.

1998 Anthracoporella; Forke et al., pl. 1, figs. 5-7, pl. 2, fig. 4, pl. 3, figs. 1, 2.

1999 Anthracoporella spectabilis; Fagerstrom and Weidlich, p. 145 (no illustration).

2000 Anthracoporella spectabilis; Granier and Grgasović, p. 11-15 (no illustration, with 85 references).

?2000 Zaporella baxoensis; Granier and Grgasović, p. 163 (no illustration, with one reference).

v.2001a Anthracoporella spectabilis; Vachard and Krainer, p. 149, 150, 151 (no illustration).

2002 Anthracoporella spectabilis; De Castro, p. 6, $8,10,11$, pl.1, figs. 1,2 , pl. 2 , figs. $1-12$, pl. 3 , figs. $1-5$.

non 2002 Anthracoporella spectabilis; Mamet, pl. 3, figs. 1, 2 (probably a Paraepimastopora).

2003 Anthracoporella; Samankassou, p. 201, 205, 208, 209, 212, 214, 215, text-figs. 8A, 12A, 12B, 13A, 13B, 19.3.

v.2003a Anthracoporella spectabilis; Krainer et al., table 1, p. 18, p. 19, pl. 3, fig. 28.

v.2003b Anthracoporella; Krainer et al., pl. 57, figs. 37, pl. 58 , figs. $4-5$.

2004 Anthracoporella spectabilis; Mamet and Villa, p. $159-160$, fig. $7 a-7 d$ (reference is made to the 85 references of synonymy lists of 
Homann (1972) and Granier and Grgasović (2000); and 12 references are added).

2004 Anthracoporella sp.; Flügel, pl. 3, figs. 3, 4.

2004 Anthracoporella spectabilis; Flügel, pl. 59, fig. 6.

2005 Anthracoporella sp.; Fohrer and Samankassou, p. $317,318,321,325,327,328$, text-fig 4a-4c.

.2005 Anthracoporella spectabilis; Fagerstrom and Weidlich, p. 511 (no illustration).

.2007a Anthracoporella; Krainer and Vachard, p. 283-284, figs. 6-8, 11.

2007 Anthracoporella; Schönlaub and Forke, figs. $11.3,11.4,22.2,23.5,23.6,149.5,149.6$, $152.3,152.4$

v2007 Anthracoporella spectabilis; Krainer, p. 633638, figs. 9, 10, 16, 17.

v2011 Anthracoporella spectabilis; Vachard and Moix, p. 154 (no illustration).

v2013 Anthracoporella spectabilis; Parvizi et al., p. 154, text-fig. 5, fig. 6 a.

v?p2017a Anthracoporella sp.; Krainer et al., pl. 37, fig. 1 (non pl. 43, fig. 5).

Description. Very rare, deformed specimens; perhaps reworked from older deposits. Length $=4,000$ $\mu \mathrm{m}$; wall thickness $=300 \mu \mathrm{m}$; diameter of laterals (pores) $=50 \mu \mathrm{m}$.

Remarks. In the Carnic Alps, Anthracoporella spectabilis is the dominant mound-forming organism in the Auernig Fm (Orenburgian = Newwellian) (Krainer et al., 2003b; Krainer, 2007). In the mounds of the Schulterkofel Fm, a few calcisponges and phylloid algae occur locally at the base and on top of some Anthracoporella mounds (Flügel, 1987; Flügel et al., 1997; Krainer, 1995a, 2007; Krainer et al., 2003b; Samankassou, 1999, 2003).

Occurrence. Rare in the Moscovian; probably cosmopolitan during the Kasimovian-Sakmarian; rare in the Artinskian (Slovenia, Kochansky and Herak, 1960; Kochansky-Devidé, 1970a; Xizang/Tibet, Mu, 1982; Thailand, Endo, 1969). Possible Lazarus effect in the Capitanian (Slovenia, Oman, Iran, Perigondwanan Afghanistan, Sumatra, Vietnam, Laos, Cambodgia, and Japan). In the Carnic Alps: Gailtal (Pia, 1920); Schulterkofel, Tröpolach, Auernig, Gartnerkofel, Krone, Zirkel (Pia, 1937); uppermost Schulterkofel Fm-Zweikofel Fm (Flügel, 1966; Homann, 1972); UP (Flügel, 1968, 1979); Forni Avoltri (Flügel and Flügel-Kahler, 1980); Auernig Fm of Kronalpe, Garnitzenberg (Krainer, 1991, 1992, 1995a); Schulterkofel (Kahler and Krainer, 1993; Krainer et al., 2003b); Auernig Fm (Vachard and Krainer, 2001b). This study: Zottachkopf Fm (samples TNA2_1_4a and Z3_2).
Anthracoporella vicina Kochansky and Herak, 1960

Figure 18.2, 18.3, Figure 20.2

$1956 b$

Anthracoporella spectabilis; Maslov, p. 9, pl. 12 , figs. 1-3 (with six references in synonymy).

1960 Antracoporella (sic) spectabilis; Bilgütay, p. 53-54, pl. 1, figs. 3, 4.

*1960 Anthracoporella vicina Kochansky and Herak, p. 69-70, pl. 1, figs. 1-5.

1963 Anthracoporella spectabilis; Maslov et al., pl. 15, figs. 1, 2.

p1963 Anthracoporella spectabilis; Johnson, pl. 9, figs. 1,2 (non pl. 8, figs. $1-3$, nec pl. 49, figs. $1-6=$ true $A$. spectabilis).

?1965 Anthracoporella spectabilis; Herak, p. 214 (no illustration; most probably Paraepimastopora).

1965 Anthracoporella spectabilis; Ramovš and Kochansky-Devidé, p. 343-344 (= 25-26), pl. 8, fig. 5 .

1966 Anthracoporella spectabilis; Flügel, p. 23-24, pl. 6, fig. 1 (with 19 references in synonymy).

?1966b Anthracoporella spectabilis; Rácz, pl. 5, fig. 27.

1968a Anthracoporella spectabilis Pia; Elliott, p. 21, pl. 2, figs. 1, 2.

1968 Anthracoporella spectabilis; Flügel, p. 46, 49, 55,56 (no illustration).

?1969 Anthracoporella spectabilis; Endo, p. 46, pl. 9 , figs. 1, 2 (with five references) (very questionable specimens).

?1970 Anthracoporella spectabilis; Nguyen Lan Tu, p. 21-22, pl. 5, figs. 1-5, pl. 6, figs. 1, 2 (with 16 references) (perhaps another species).

1970a Anthracoporella vicina; Kochansky-Devidé, p. 212 , p. 240 , pl. 22, fig. 4.

?1970b Anthracoporella spectabilis; Kochansky-Devidé, p. 12, pl. 4, fig. 1.

1971 A nthracoporella spectabilis; Ramovš, pl. 2, fig. 1.

1972 Anthracoporella spectabilis; Homann, p. 189-191, pl. 3, fig. 23 (with 38 references in synonymy).

1974 Anthracoporella spectabilis; Chuvashov, p. 20-21, pl. 6, figs. 1-6.

1976 Anthracoporella vicina; Emberger, p. 21 (no illustration) (with eight references).

?1977 Anthracoporella spectabilis; Vachard in Montenat et al., pl. 9, fig. 2.

1978 Anthracoporella spectabilis; Kulik, p. 191193, pl. 4, figs. 1-6.

1979 Anthracoporella spectabilis; Flügel, p. 572 (no illustration). 
1979

Anthracoporella vicina; Flügel, p. 572 (no illustration).

?v1980 Anthracoporella spectabilis; Vachard, p. 347348 , pl. 5 , figs. $2-4$, pl. 23 , figs. $6-8$ (= another species).

1980 Anthracoporella spectabilis; Flügel and Flügel-Kahler, p.123-124, pl. 7, fig. 7 (with 14 references in synonymy).

v1981 Anthracoporella spectabilis; Vachard in Vachard and Montenat, p. 35, pl. 3, fig. 1 (with 16 references).

v1981 Anthracoporella vicina; Vachard in Vachard and Montenat, p. 34 (no illustration).

1981 Anthracoporella spectabilis; Ramovš and Kochansky-Devidé, pl. 1, fig. 5.

1982 Anthracoporella spectabilis; Mu, p. 219-220, pl. 5, fig. 7.

1982 Anthracoporella spectabilis; Milanović, pl. 10, fig. 3.

?1984 Anthracoporella spectabilis; Flügel, Kochansky-Devidé and Ramovš, p. 194, pl. 29, fig. 3.

1984b Anthracoporella spectabilis; Saltovskaya, pl. 31, figs. 1-3.

1985 Anthracoporella; Roux, pl. 4, fig. 2.

p1985 Anthracoporella spectabilis; Mu, pl. 14, fig. 8 (non fig. 7 = Anthracoporella? sp.).

1986a Anthracoporella spectabilis; Nguyen Duc Tien, pl. 9, fig. 1B, pl. 10, fig. 2.

?1986b Vermiporella nipponica; Nguyen Duc Tien, pl. 15, fig. 9 (probably another genus).

1986b Vermiporella nipponica; Nguyen Duc Tien, pl. 15, fig. 1.

1987 Anthracoporella spectabilis; Flügel, pl. 7, figs. 1-6, pl. 8, figs. 1-8.

?1987 Anthracoporella spectabilis; Delvolvé et al., p. 544,545 , pl. 1 , fig. 5 (perhaps another species).

1988 Anthracoporella spectabilis; Sartorio and Venturini, p. 36 (not numbered illustration).

1988 Anthracoporella spectabilis; Nguyen Duc Tien in Fontaine et al., pl. 2, figs. 14, 15.

non 1991 Anthracoporella; Riding and Guo, fig. 7 (another genus).

1991 Anthracoporella spectabilis; Krainer, fig. 4.

1991 Anthracoporella; Krainer, fig. 2.

1991 Anthracoporella spectabilis; Wu, p. 756-757, pl. 1, fig. 3, pl. 2, fig. 4.

1992 Anthracoporella spectabilis; Krainer, pl. 6, fig. 4.

1992 Anthracoporella; Krainer, fig. 31, pl. 36, fig. 3.

1993 Anthracoporella; Krainer, text-fig. 19.

1993 Anthracoporella spectabilis; Kahler and Krainer, pl. 67, fig. 3.
1995 Anthracoporella spectabilis; Pajić and Filipović, pl. 49, figs. 1-4, 6, pl. 51, figs. 1-6.

1995 Anthracoporella spectabilis; Forke, p. 240, pl. 15/3.

1995a Anthracoporella; Krainer, pl. 38, figs. 4, 5, pl. 39, fig. 6, pl. 41, fig. 1.

1995a Anthracoporella spectabilis; Krainer, pl. 40, figs. 5, 6, pl. 41, figs. 5, 6 .

?2001a Anthracoporella spectabilis; Vachard et al., p. 385, 387, fig. 12.1-12.10 (= another species?).

Description. Outer diameter $=1,500-1,825(-$ $3,600) \mu \mathrm{m}$; inner diameter $=450-600-(800-2,000)$ $\mu \mathrm{m}$; wall thickness $=500-600(-750) \mu \mathrm{m}$; lateral diameter $=20-50 \mu \mathrm{m}$; lateral diameter $($ pores $)=$ $15-20 \mu \mathrm{m}$; interpores $=7-10 \mu \mathrm{m}$; diameter of endospores $=20-30 \mu \mathrm{m}$; number of endospores: 25; diameter of pores in endospores $=3-5 \mu \mathrm{m}$.

Remarks. Anthracoporella spectabilis and $A$. vicina having the same distribution, Upper Pennsylvanian to Lower Permian, and being often associated, they represent possibly two stages or two morphologies of the same species. Traditionally, they are considered as two species.

Occurrence. Late Pennsylvanian-Early Permian of Croatia, Slovenia, the Urals (Russia), Turkey (compiled in this work). This study: Zweikofel Fm (sample GB58_6); Zottachkopf Fm (samples TNA2_1_4a; TNA2_1_5; TNA2_2_1); basal Trogkofel Fm (sample TM_3a); and Trogkofel Fm (samples TK46_2; TK 50_2_1).

Tribe EPIMASTOPOREAE Vachard, Krainer and Lucas, 2012

Description. See the descriptions of the subtribe Epimastoporellineae Cózar and Vachard, 2004, and tribe Epimastoporeae Vachard, Krainer and Lucas, 2012. Large fragments of cylindrical, clubshaped or most commonly subspherical dasycladales. Broad central cavity and relatively thin walls. Lateral simple, numerous, aspondyl but almost euspondyl and having some shapes relatively uncommon among the dasycladales; i.e., prismatic, "clepsydral" (Barattolo et al., 1993), ellipsoidal, sometimes very inflated in the centre, dumbbell-like, etc. (perhaps in relation with an unknown mode of reproduction). They communicate with the exterior by a small pore or apparently have no preserved connections (Globuliferoporella). Outer and inner surfaces generally smooth but intusannulations exist in Paraepimastopora.

Composition. Epimastopora (Pia, 1922) Elliott, 1956 emend. herein (= Epimastoporella Roux, 1979 nom. superfl. = "Embergerella" Güvenç, 1972 
pre-occupied, see Granier and Deloffre, 1994 p. 50); Epiastopora n. gen.; Palaepimastoporella Cózar and Vachard, 2004; Paraepimastopora Roux, 1979 emend. Krainer and Vachard, 2002; Globuliferoporella Chuvashov, 1974; ?Borisovella Ivanova, 1988; ?Sphenoporella Chuvashov in Chuvashov and Anfimov, 1988 (see discussion in Cózar and Vachard, 2004).

Remarks. The group of the Epimastoporeae, homogenous and sufficiently distinct of the Gyroporelleae by the shapes of laterals and thalli, has been only relatively recently considered as constituting a tribe (Vachard et al., 2012). The members of this tribe were before emplaced in the tribe Mastoporeae (Deloffre, 1988, p. 170).

Occurrence. Late Viséan to Late Permian; cosmopolitan in the Late Pennsylvanian-Early Permian, or, otherwise, Paleotethyan.

\section{Genus PARAEPIMASTOPORA Roux, 1979} emend. Krainer and Vachard, 2002

Synonyms. Epimastopora (part.); Anthracoporella (part.), Anchicodium (part.).

Type species. Epimastopora kansasensis Johnson, 1946; by original designation.

Diagnosis. Thallus probably cylindrical or clubshaped with regular intusannulations, poorly calcified and often broken. Skeleton perforated by numerous, thin, acrophore laterals, closely spaced, and with relatively thickly calcified interpores.

Other species. Epimastopora jewetti Johnson, 1946; E. kanumai Endo in Endo and Kanuma, 1954; E. lateinterporosa Endo, 1961a; E. longituba Endo, 1957; E. regularis Johnson, 1946; E. urtazymensis Chuvashov and Anfimov, 1988; E. sp. 1 sensu Chuvashov, 1974; Paraepimastopora noetschensis Krainer and Vachard, 2002; P. somervillei Vachard and Cózar in Vachard, Cózar, Aretz and Izart, 2016.

Remarks. Contrary to Granier and Deloffre (1994), we think that Paraepimastopora and Tauridium Güvenç, 1966, are not synonymous; Tauridium, as well as Dzhulfanella or Pyrulites, most probably represent different stages of preservation of Permocalculus (Vachard et al., 2005).

Occurrence. Rare in the late Viséan-Serpukhovian of the Paleotethys (Vachard et al., 2012, 2016); common in the Middle-Late Pennsylvanian and probably cosmopolitan (Vachard et al., 2012); rare in Early-Middle Permian (Parvizi et al., 2013).

\section{Paraepimastopora kanumai (Endo in Endo and}

Kanuma, 1954)

Figure 18.4, 18.5?
*1954 Epimastopora kanumai Endo in Endo and Kanuma, p. 195, pl. 13, figs. 8-10.

1957 Epimastopora kanumai; Endo, p. 285, pl. 37, figs. 9, 10, pl. 38, fig. 1.

1957 Epimastopora kanumai; Endo and Horigushi, p. 171-172, pl. 13, fig. 5, pl. 14, figs. 1, 2 (with two references in synonymy).

1961a Epimastopora kanumai; Endo, p. 184-185, pl. 30, fig. 5 (with three references in synonymy).

1961c Epimastopora kanumai; Endo, p. 126-127, pl. 1, figs. 1-3, pl. 2, fig. 2 (with five references in synonymy).

1963 Epimastopora kanumai; Johnson, p. 110 111, pl. 57, figs. 3-9.

1966 Anthracoporella spectabilis Pia; Flügel, p. 23-24, pl. 6, fig. 1.

1968 Epimastopora kanumai; Flügel, p. 56 (no illustration).

1969 Epimastopora kanumai; Endo, p. 80, pl. 41, figs. 2, 3 (with six references in synonymy).

1972 Epimastopora kanumai; Homann, p. 199201, pl. 4, fig. 26 (with 14 references in synonymy).

?.1973 Orthriosiphon; Maslov, pl. 11, fig. 6 (another aspect of a not perforated intusannulation).

1974 Anchicodium sindbadi Elliott; Chuvashov, p. 16 , pl. 1, figs. 1-4 (erroneously synonymized with Anthracoporella spectabilis by Granier and Grgasović, 2000).

1976 Epimastopora kanumai; Emberger, p. 40 (no illustration).

?.1979 Epimastopora kansaensis (sic) Johnson; Flügel, p. 572 (no illustration)

1979 Epimastopora kanumai; Flügel, p. 572 (no illustration).

?1980 Epimastopora seleukensis Kulik; Flügel and Flügel-Kahler, p. 152-153, pl. 6, fig. 3 (right).

?1980 Epimastopora camasobresensis; Flügel and Flügel-Kahler, p. 148-149, pl. 6, fig. 5.

?1980 Epimastopora kansasensis; Flügel and Flügel-Kahler, p. 148-149, pl. 6, fig. 6.

non1980 Epimastopora cf. kanumai; Flügel and Flügel-Kahler, p. 149, pl. 6, fig. 7 (probably Calcipatera; see later).

v1981 "Epimastopora" kanumai; Vachard in Vachard and Montenat, pl. 3, fig. 3.

?1981 Epimastopora sp. C; Mu, p. 45, pl. 4, fig. 4. 1982 Epimastopora kanumai; Mu, p. 225, pl. 5, fig. 6.

?1985 Epimastopora kansasensis; Mu, pl. 14, fig. 1. 1987 Epimastopora kanumai; Mamet et al., p. 35 (attributed to Paraepimastopora) (no illustration). 

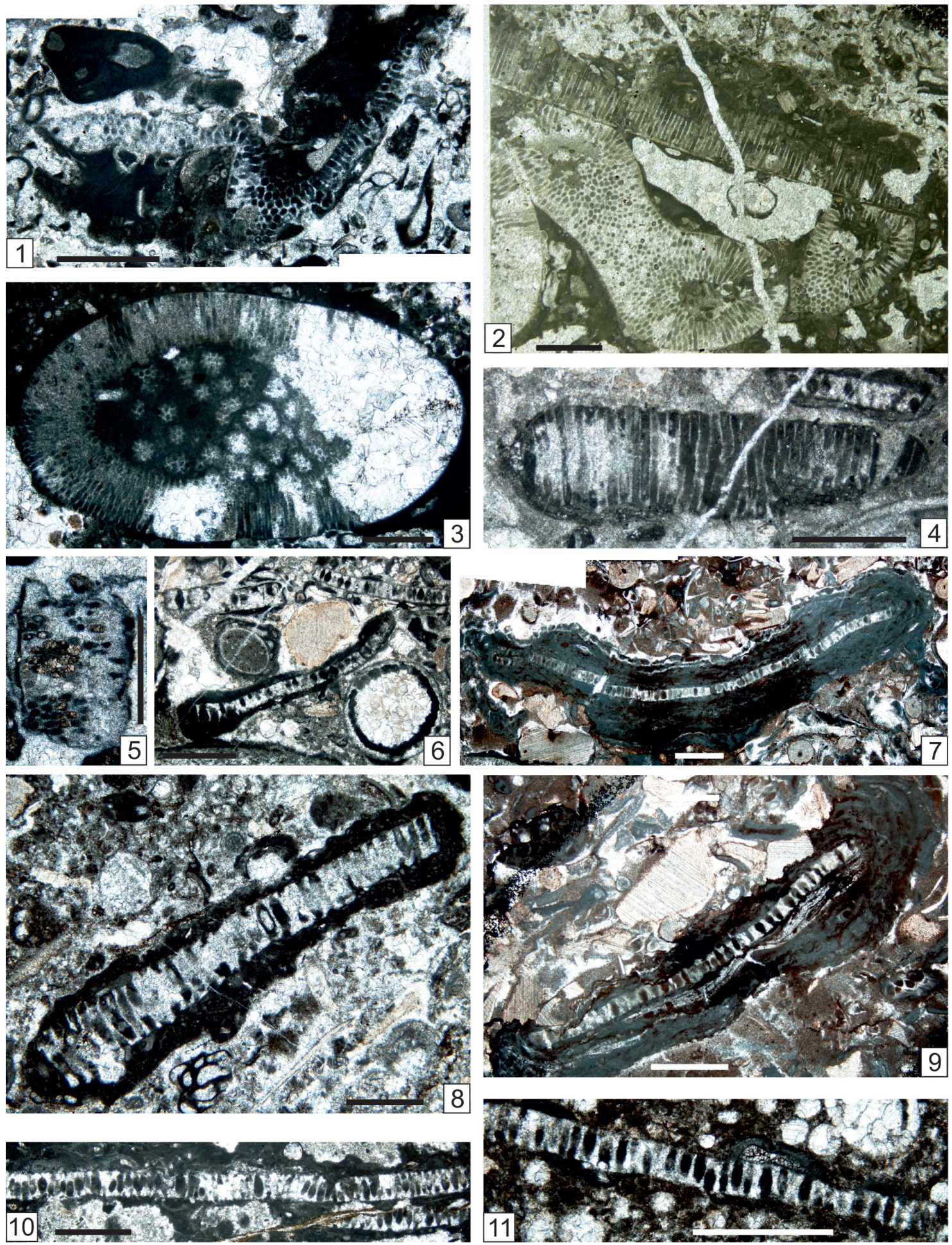

FIGURE 18. 1. Anthracoporella spectabilis Pia, 1920. Deformed, longitudinal section. Sample TNA2_1_4a. 2, 3. Anthracoporella vicina Kochansky and Herak, 1960. 2. Several sections in different planes. Sample TNA2_1_5. 3. Fertile specimen with endospores. Sample TNA2_2_1. 4, 5? Paraepimastopora kanumai (Endo in Endo and Kanuma, 1954). 4. Fragment of thallus in longitudinal section. Sample GB58_6. 5. Fragment of thallus in tangential section. Sample TK46_2. 6, 7, 9. Epimastopora japonica Endo, 1951 emend. Mamet, Roux and Nassichuk, 1987. Different longitudinal sections. 6. Sample TKS2_1. 7. Sample TNA18_2_1a. 9. Sample TNA18_2. 8, 10, 11. Epimastopora likana Kochansky and Herak, 1960 emend. herein. Two longitudinal sections. 8. Sample TKW9B_3. 10. Sample TNC5_4. 11. Sample ZK199_A. Scale bar $=1 \mu \mathrm{m}$. 
v1993b Epimastopora kanumai; Vachard et al., pl. 1, fig. 4.

1994 Paraepimastopora kanumai; Granier and Deloffre, p. 70 (no illustration).

2000 Epimastopora kanumai [cf. Paraepimastopora kanumai]; Granier and Grgasović, p. 56 (no illustration).

2000 Paraepimastopora kanumai [= Epimastopora kanumai]; Granier and Grgasović, p. 118-119 (no illustration) (with 17 references in synonymy).

v2015 Paraepimastopora kanumai; Krainer et al., fig. 17.3, 17.4 .

Description. A species with relatively wide laterals, round pores, thick wall and intusannulations rarely preserved (only illustrated by Homann, 1972). The interpore width is half to equal to the lateral diameter. Length of thallus $=3,500-7,000$ $\mu \mathrm{m}$; thickness of the thallus $=600-850 \mu \mathrm{m}$; lateral diameters (pores) $=60-90 \mu \mathrm{m}$; width of interpores = 50-105 $\mu \mathrm{m}$.

Remarks. The similar species $P$. urtazymensis is less thick, and with less numerous laterals. Although coeval with $P$. urtazymensis (from Podolskian of the Urals), our material is more similar to P. kanumai.

Occurrence. Late Pennsylvanian-Middle Permian of the Urals, Carnic Alps (Austria; Italy), Serbia, Greece, Afghanistan, Xinjiang and Xizang (China), Thailand, Japan and New Mexico (compiled in this study). In the Carnic Alps: Schulterkofel and Zweikofel formations (Flügel, 1968, 1979); Forni Avoltri (Flügel and Flügel-Kahler, 1980). This study: Zweikofel Fm (samples GB58_6; ZK65_1_C) and Trogkofel Fm (samples GBT3_3; TK46_ㄹ).

Genus EPIMASTOPORA Pia, 1922 emend. herein

Synonyms. Epimastoporella Roux, 1979; Pseudoepimastopora (in the sense of Homann, 1972); "Embergerella" Güvenç, 1972 pre-occupied.

Type species. Epimastopora japonica Endo, 1951 emend. Mamet et al., 1987, subsequently designated herein.

Emended diagnosis. Large fragments of subspherical epimastoporeae. Lateral simple, numerous, aspondyl but almost euspondyl, inflated and ellipsoidal in the central part, thin and cylindrical in the distal and proximal extremities.

Other species. Succodium ambiguum Kordé, 1965; Embergerella anatoliana Güvenç, 1972; Pseudoepimastopora croatica Homann, 1972 (sic: kroatica; nomen correctum by Kulik, 1978); Epimastopora hunrazensis Zanin Buri, 1965 (part.: holotype pl. 8, fig. 6; but the majority of the illustrated specimens belong to Epiastopora; see later);
E. iwaizakiensis Endo, 1953a; E. ketini Bilgütay, 1960; E. kosakiensis Konishi, 1954a; ?E. minima sensu Homann, 1972 (non Elliott, 1956 = a gymnocodiacean).

Excluded species. Epimastopora alpha Elliott, 1956 (nomen incorrectum); E. beta Elliott, 1956 (nomen incorrectum); E. bashkirica Kulik, 1978 (= ?Gyroporella); E. cekici sensu Chuvashov et al., 1987; E.? crassitheca Chuvashov and Anfimov, 1988 (= Pseudoepimastopora or Atractyliopsis auctorum); E. densipora Endo, 1969 (= Paraepimastopora); E. digitula Chuvashov and Anfimov, 1988 (gyroporellacean?); E. faveolata Shuysky and Patrunov, 1991 (mastoporellacean?); E. jewetti Johnson, 1946 (= Parepimastopora); E. kansasensis Johnson, 1946 (= Parepimastopora); E. kanumai Endo, 1954 (= Parepimastopora); E. lateinterporosa Endo, 1961d (= Parepimastopora); E. longituba Endo, 1956; E. macropora sensu Perret and Vachard, 1977 (Borisovella?); E. minima Elliott, 1956 (a gymnocodiacean); E. oblonga Shuysky and Patrunov, 1991 (= a Devonian seletonellacean); E. regularis Johnson, 1946 (= Paraepimastopora); E. urtazymensis Chuvashov and Anfimov, 1988 (= Paraepimastopora); E.? tenuis Berchenko, 1982 (invalid because not described; moreover, the illustrations correspond to a kirkbyid ostracod); E.? sphaenopora Chuvashov, 1974 (= Sphaenoporella Chuvashov and Anfimov, 1988). On the other hand, Epimastopora malaysiana Elliott, 1968b, and E. tomurica Mu, 1985 are most probably two species of Anthracoporella; see earlier).

Remarks. Despite its cosmopolitan distribution and its huge productivity, the genus Epimastopora remained taxonomically disputed. Recently, Parvizi et al. (2013, p. 154-155) discussed the nomenclatural proposals of Elliott (1956), Kochansky-Devidé and Herak (1960), Roux (1979), and Granier and Deloffre (1995). Parvizi et al. (2013) suggested that 1) the genus Epimastoporella Roux, 1979, cannot be distinguished from Epimastopora (Pia, 1922) ex Kochansky and Herak, 1960; 2) Epimastopora sensu Roux, 1979 is evidently preoccupied by Globuliferoporella Chuvashov, 1974.

Before that, Homann (1972) considered two different groups of epimastoporaceans; he called Epimastopora the taxa with prismatic/clepsydral laterals, and Pseudoepimastopora the taxa with ellipsoidal laterals. Nevertheless, Homann has given a misinterpretation of the so-called Pseudoepimastopora, which was not consistent with that of its type species: Pseudoepimastopora pertunda Endo, 1960 (see later). On the other hand, the 
reconstruction of Epimastoporella as a cylindrical alga (Roux, 1979) is another misinterpretation, because the different species of this taxon and especially the type species Epimastopora japonica Endo, 1951 selected by Roux (1979) himself, have a spherical thallus. In contrast, Roux's reconstruction is more consistent with the primitive Viséan genus Palaepimastoporella.

Although described before the revision of Kochansky and Herak (1960), the "Epimastopora" species of Johnson (1946), Kordé (1951) and Endo (1951) cannot be used as type species for this genus, because: 1) they were described very remote from the type areas in the Carnic Alps; 2) they did not correspond to the intentions of Pia (1922), who worked only with European material (see, in this regard, the Recommendations 9A.3 and 10.5 of the International Code of Botanical Nomenclature); 3) two of these species belong nowadays to distinct, valid genera because the taxon of Kordé (1951) "E." piai, has been reassigned to Globuliferoporella (see later), and that of Johnson (1946), "E." kansasensis, to Paraepimastopora. Another nomenclatural problem discussed by Parvizi et al. (2013) was the possible designation, as type species of Epimastopora, of either Epimastopora beta Elliott, 1956 (precisely created as a synonym of Gyroporella? n. f. indet. in the sense of Gortani, 1906, plate 1, figure 2) or Epimastopora alpina Kochansky and Herak, 1960 (= Epimastopora sp. in the sense of Pia, 1937, plate 97, figure 4). After this study and our new revision of the literature, it is undisputable that: 1) the emendation of Elliott (1956) was inconsistent with the Botanical Code in force at that time (see Granier and Grgasović, 2000 and Parvizi et al., 2013); 2) similarly, Epimastopora beta was invalid, and therefore cannot be the type species of Epimastopora; 3) in contrast Epimastopora japonica Endo 1951, as emendated by Mamet et al., 1987, is present in our material and probably synonymous of Gyroporella n.f. indet. sensu Gortani (see later) and can be admitted as type species of Epimastopora. On the other hand, morphological differences can be characterized with the group "Epimastopora" alpina that is designated in this paper as the type species of Epiastopora n. gen.

Occurrence. Moscovian-late Middle Permian, cosmopolitan (even if Pia, 1937, p. 829, indicated initially, that Epimastopora "was only known in the Trogkofel Limestone of the Carnic Alps and Karawanken").
Epimastopora japonica Endo, 1951 emend.

Mamet, Roux and Nassichuk, 1987

Figure 18.6-9, Figure 19.1-2, 19.6-9, 19.12 (left)

p1906 ?Gyroporella n. f. ind. Gortani, p. 7, pl. 1, fig. 1.

p1937 Epimastopora nov. sp.; Pia, pl. 97, fig. 4 (both large specimens; right).

*1951 Epimastopora japonica Endo, p. 124-125, pl. 11, figs. 1, 2.

1953b Epimastopora japonica; Endo, p. 99-100, pl. 9, figs. 1-4.

1956 Epimastopora alpha Elliott, p. 327 (invalid new name proposed for the Gortani's taxon).

1960 Pseudoepimastopora japonica; Endo, p. 269-270, pl. 44, fig. 1.

1961a Epimastopora japonica; Endo, p. 203-204, pl. 38, figs. 16-18.

1963 Epimastopora japonica; Johnson, p. 111 (no illustration).

1963 Pseudoepimastopora japonica; Johnson, p. 120, pl. 69, fig. 1.

1969 Pseudoepimastopora japonica; Endo, p. 49, pl. 46, figs. 5-7.

1972 Pseudoepimastopora japonica; Homann, p. 225-226, pl. 5, fig. 34 (with 10 references in synonymy).

.1976 Epimastopora japonica; Emberger, p. 40 (no illustration).

.1976 Pseudoepimastopora japonica; Emberger, p. 69 (no illustration) (with eight references).

1979 Epimastoporella japonica; Roux, p. 809 (no illustration).

1987 Epimastoporella japonica; Mamet et al., p. $34-35$, pl. 15, figs. $6-12$, pl. 16, figs. 1-3 (with 17 references in synonymy).

?1995 Epimastopora japonica; Pajić and Filipović, pl. 48, figs. 6, 8.

2000 Epimastopora alpha; Granier and Grgasović, p. 59 (no illustration).

2000 Epimastoporella japonica; Granier and Grgasović, p. 62-64 (with 45 references in synonymy and no illustration).

v2013 Epimastoporella japonica; Parvizi et al., p. 155, 157, fig. $6 \mathrm{~g}$.

v2015 Epimastopora japonica; Lucas et al., fig. 40.24 .

Description. The relatively irregular arrangement of the elongate fusiform laterals is characteristic. Length of remains $=3,300-7,500 \mu \mathrm{m}$; width of remains $=200-400 \mu \mathrm{m}$; diameter of pores (= laterals) $=80-100 \mu \mathrm{m}$; interpore width $=25-40 \mu \mathrm{m}$.

Occurrence. Early Permian of Turkey, Austria, Italy, Slovenia, Urals, Sumatra, Tibet, ?New Mexico. ?Guadalupian of Slovenia and Iran. In the Car- 

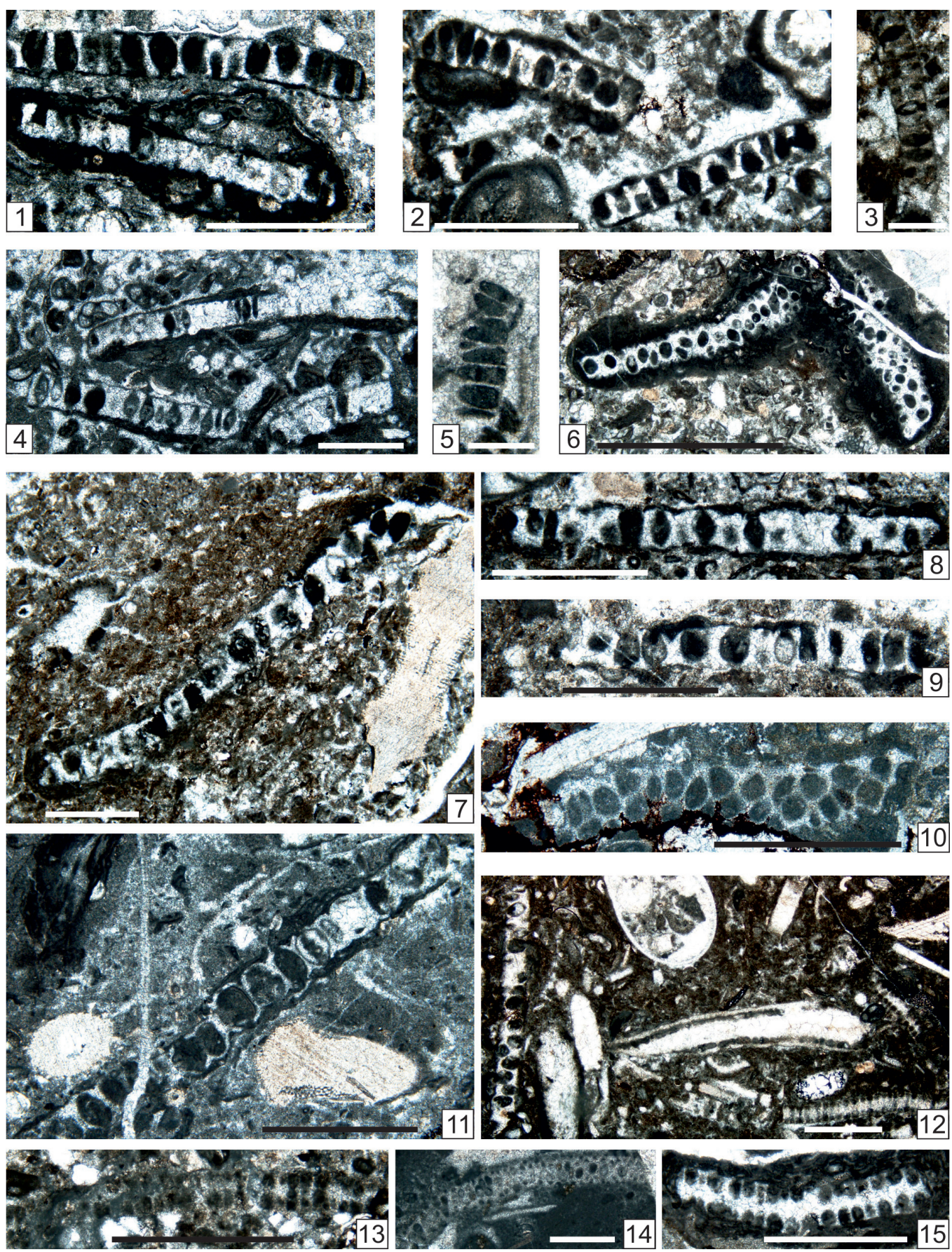

FIGURE 19. 1, 2, 6-9, 12 (left). Epimastopora japonica Endo, 1951 emend. Mamet, Roux and Nassichuk, 1987. Several longitudinal and oblique sections. 1. Sample TNC7_1. 2. Sample Z6_3. 3. Sample ZK98_18. 4. Sample ZT1_3. 6. Sample TKW5B_4b. 7. Sample TKW12_2a. 8. Sample TKW5B_3. 9. Sample Z5_1. 12. Sample ZK188_1_A. 3, 4. Epimastopora likana Kochansky and Herak, 1960 emend. herein. Several longitudinal sections. 3. Sample ZK98_18. 4. Sample ZT1_3. 5, 10. Epiastopora alpina (Kochansky and Herak, 1960) n. gen. n. comb. 5. Longitudinal section. Sample GB60_8. 10. Transverse section. Sample TNA1_2_2. 11. Epiastopora fluegeli (Kulik, 1978) n. comb. Longitudinal section. Sample TKW13B_8. 12, 13, 15. Globuliferoporella piai (Kordé, 1951). Several longitudinal sections. 12. (right: bottom and center) with Epimastopora japonica Endo, 1951 emend. Mamet, Roux and Nassichuk, 1987 (left), E. likana Kochansky and Herak, 1960 emend. herein (bottom center) and Eugonophyllum magnum (Endo, 1951) emend. Konishi and Wray, 1961 (center). Sample ZK188_1_A. 13. Sample ZK184_1. 15. Sample TKW10_2B. 14. Epimastopora cf. izawaikensis Endo, 1953a. Sample TK55_1. Scale bars: $0.5 \mu \mathrm{m}$ (Figures 19.3, 19.5); all others $=1$ $\mu \mathrm{m}$. 
nic Alps: Schulterkofel Fm to Trogkofel Fm (Flügel, 1968, 1979; Vachard and Krainer, 2001b); Tröpolacher Alm, Seikofel, Forni Avoltri, Trogkofel, Reppwand, Goggauer Kalk, Treßdorfer Kalk (Flügel and Flügel-Kahler, 1980); this study: Zweikofel Fm (samples GB60_8; ZK98_18; ZK188_1_A); Zottachkopf (samples TKS2_1; TKW5B_3; TKW5B_4b; TKW12_2a; TKW $13 B$ 8; $\quad$ TNA1_2_2; TNA18_2_1a; TNA18_2; TNC7_1; Z5_1; Z6_3; ZT1_3); and basal Trogkofel Fm (sample TM7_1a).

Epimastopora likana Kochansky and Herak, 1960 emend. herein

Figure 18.8, 18.10-11, Figure 19.3-4, 19.12

(bottom, center), Figure 20.3, Figure 22.3, 22.6?, Figure 27.2?, 27.5

p1906 ?Gyroporella n. f. ind. Gortani, p. 7, pl. 1, fig. 2 (non fig. 1 = E. japonica).

1956 Epimastopora beta Elliott, p. 327 (invalid nom. nov. for the previous taxon).

*1960 Epimastopora likana Kochansky and Herak, p. 78-79, pl. 4, figs. 5-10 (valid name for the figure 2 of Gortani).

1962 Epimastopora likana; Kochansky-Devidé and Milanović, p. 216-217, pl. 6, fig. 3.

1963 Pseudoepimastopora likana; H. Flügel, p. 87-88, pl. 1, fig. 5.

1965 Epimastopora likana; Herak, p. 214 (no illustration).

1966 Pseudoepimastopora likana; E. Flügel, p. $42-43$, pl. 7, figs. 3, 4 (with five references in synonymy).

1968 Pseudoepimastopora likana; E. Flügel, p. 56 (no illustration).

?1968 Epimastopora japonica; E. Flügel, p. 55, 56 (no illustration).

1970a Epimastopora likana; Kochansky-Devidé, p. 214, 241, pl. 23, fig. 9.

1972 Pseudoepimastopora likana; Homann, p. 228-230, pl. 4, fig. 33, pl. 5, fig. 37 (with 13 references in synonymy).

?1972 Embergerella anatoliana Güvenç, p. 22-24, figs. 1-3.

1974 Pseudoepimastopora likana; Chuvashov, p. 25-26, pl. 11, figs. 1-8.

1976 Epimastopora likana; Emberger, p. 41 (no illustration).

$1976 \quad$ Pseudoepimastopora likana; Emberger, p. 71 (no illustration) (with 15 references).

non 1978 Pseudoepimastopora likana; Kulik, p. 201203, pl. 6, figs. 3-4 (probably Epiastopora).

1978 Pseudoepimastopora likana; Lys et al., pl. 5, fig. 2a, 2b.

.1979 Pseudoepimastopora izawaikensis (Endo); Flügel, p. 572 (no illustration).
$? .1979$

Pseudoepimastopora japonica; Flügel, p. 572 (no illustration).

?.1979 Pseudoepimastopora kroatica Homann; Flügel, p. 572 (no illustration).

1979 Pseudoepimastopora likana; Flügel, p. 572 (no illustration).

non 1979 Pseudoepimastopora likana; Zagorodnyuk, p. 7, pl. 1, fig. 5 (= Globuliferella piai).

p1980 Epimastopora alpina Pia; Flügel, pl. 6, figs. 1, 2 (only a true $E$. alpina is visible in the top center of fig. 2).

1980 Epimastopora piae Bilgütay; Flügel, pl. 6, figs. 3, 4.

p.1980 Epimastopora; Flügel, pl. 8, fig. 1 (center only; other figures (top) are E. ex gr. alpina).

p1980 Epimastopora alpina; Flügel and FlügelKahler, p. 142-144, pl. 2, figs. 1, 2, pl. 7, fig. 9 (non pl. 5, figs. 3-5 = Epiastopora alpina; non pl. 5, fig. 6, $7=$ other genera).

1980 Epimastopora? likana; Flügel and FlügelKahler, p. 149-151, pl. 1, fig. 6, pl. 6, fig. 6, pl. 7, figs. 4-6, 8 (with 5 references in synonymy).

?1980 "Epimastopora" likana; Vachard, pl. 23, figs. 3, 9 (probably another species).

?1981 "Epimastopora" likana; Vachard in Vachard and Montenat, p. 36, pl. 3, figs. 4?, 6.

?1982 Epimastopora iwaizakensis; Mu, p. 229, pl. 6, figs. 3, 4.

?1985 Epimastopora piae; Mu, pl. 3, figs. 3, 4.

?1990 Pseudoepimastopora likana; Flügel, pl. 2, fig. 1 (an atypical oblique section).

1991 Epimastoporella; Riding and Guo, fig. 8.

1993b Pseudoepimastopora likana; Vachard et al., pl. 1, fig. 6.

1997 Pseudoepimastopora likana; Vachard et al., fig. 12.15.

1997 Epimastopora likana; Sokač et al., p. 145 (no illustration).

2000 Epimastoporella japonica; Granier and Grgasović, p. 57, 62-64, 65, figs. 12, 13 (with 45 references in synonymy).

2007 Epimastopora sp.; Schönlaub and Forke, figs. 23.1, 23.2, 149.1, 149.2.

v2009 Epimastopora ex gr. likana; Krainer et al., p. 13, pl. 4, fig. 16.

v2011 Epimastopora likana; Vachard and Moix, p. 154, 156 (no illustration).

v2012 Epimastopora likana; Kolodka et al., p. 138, 139, fig. 8a-8b.

v2012 Epimastopora ex gr. likana; Vachard et al., p. 235, 239-240, pl. 1, fig. 4.

v2013a Epimastopora ex gr. likana; Vachard et al., p. 7 (no illustration). 
v.2013 Epimastoporella likana; Parvizi et al., p. 157, fig. $6 \mathrm{~b}-6 \mathrm{~d}$.

?v.2015 Epimastopora ex gr. E. japonica; Krainer et al., fig. 20.5 .

v.2017 Epimastopora likana; Lucas et al., p. 15 (no illustration).

v.2017a Epimastopora likana; Krainer et al., p. 20, pl. 24, fig. 7, pl. 35, figs. 10?, 14 ?

v.2017a Epimastopora cf. japonica; Krainer et al., p. 20 (no illustration).

Description. The elongate fusiform shape of the laterals is characteristic. Length of remains = 1,000-3,500 $\mu \mathrm{m}$; width of remains $=200-300 \mu \mathrm{m}$; diameter of pores (= laterals) $=60-100 \mu \mathrm{m}$; interpore width $=30-60 \mu \mathrm{m}$.

Occurrence. Late Pennsylvanian-Late Permian; cosmopolitan (Italy, Croatia, Slovenia, Austria, Greece, Urals, Turkey, Iran, Afghanistan, Guatemala, New Mexico). Middle Permian specimens of Turkey were probably described as Embergerella anatoliana Güvenç, 1972. In the Carnic Alps: Schulterkofel Fm (questionable) and Zweikofel Fm (Flügel, 1968, 1979); Forni Avoltri, Tarviser Brekzie (Flügel and Flügel-Kahler, 1980). This study: Zweikofel Fm (samples GB156_8; ZK97_19; ZK98_18; ZK99_A; ZK188_1_A; ZK188_3; ZK199_A); Zottachkopf Fm (samples TKS2_1; TKS2_2; TKW5B_3; TKW5B_4a; TKW5B_4b;

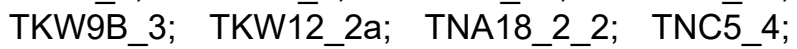
TNC7_1; Z5_1; Z6_3; ZT1_3); and basal Trogkofel Fm (sample TM7_1a).

Epimastopora cf. izawaikensis Endo, 1953a Figure 19.14, Figure 20.6

*1953a Epimastopora izawaikensis Endo, p. 120121, pl. 11, figs. 7-9.

1972 Pseudoepimastopora izawaikensis; Homann, p. 223-224, pl. 5, fig. 36.

1976 Epimastopora izawaikensis; Emberger, p. 41 (no illustration).

1976 Pseudoepimastopora izawaikensis; Emberger, p. 69 (no illustration) (with four references).

1979 Epimastopora izawaikensis; Mamet et al., pl. 3 , figs. 4, 5 .

1982 Epimastopora izawaikensis; Mu, p. 229, pl. 6, figs. 3, 4.

1984 Pseudoepimastopora izawaikensis; Flügel et al., p. 195, pl. 30, fig. 4.

?1987 Epimastoporella izawaikensis; Mamet et al., p. 33-34, pl. 16, figs. 4-13.

$1991 \quad P$ Pseudoepimastopora izawaikensis; Flügel et al., pl. 47, fig. 7 .

?1991 Epimastopora; Riding and Guo, fig. 5.
Description. Length of remains $=1,650-5,500$ $\mu \mathrm{m}$; width of remains $=250-310 \mu \mathrm{m}$; diameter of pores $(=$ laterals $)=75-100 \mu \mathrm{m}$; interpore width $=$ 100-150 $\mu \mathrm{m}$.

Occurrence. Moscovian-Permian of Japan, Turkey, Canadian Arctic (Mamet et al., 1987), Sicily, China, Croatia (this compilation). In the Carnic Alps (this study): Zweikofel Fm (sample GB136_2); basal Trogkofel Fm (samples TM5_2; TM7_1b); and Trogkofel Fm (sample TK55_1).

Genus EPIASTOPORA n. gen.

Synonyms. Epimastopora (part.); ?Epimastoporella (part.), ?Pseudoepimastopora (part.)

Type species. Epimastopora alpina Kochansky and Herak, 1960; by original designation, herein.

Diagnosis. Thallus probably spherical and with a large central cavity. Laterals simple, aspondyl to almost euspondyl, prismatic in shape (Homann, 1972, plate 4, figure 25, plate 5, figure 39; Chuvashov, 1974, plate 11, figures 3-6; Kulik, 1978, plate 5, figure 3; Milanović, 1982, plate 10, figure 2; Krainer, 1991, text-figure 1) or clepsydral (according to Barattolo et al., 1993).

Other species. Epimastopora bodoniensis Rácz, 1966a; E. camasobresensis Rácz, 1966b; E. fluegeli Kulik, 1978; E. grandis Chuvashov et Anfimov, 1988; E. hunrazensis Zanin Buri, 1965 (part.); E. rolloensis Rácz, 1966a; E. seleukensis Kulik, 1978; ?Epimastoporella sp. sensu Sebbar and Mamet, 1999; ?Pseudoepimastopora likana sensu Kulik, 1978; P. shatchtauensis Kulik, 1978.

Remarks. Although poorly known in the Early-Middle Pennsylvanian (Rácz, 1966b; Chuvashov and Anfimov, 1988), Epiastopora may derive from the late Viséan-Serpukhovian taxon Palaepimastoporella, as early as in the early Bashkirian, with a transitional form more or less similar to Epimastoporella sp. sensu Sebbar and Mamet, 1999 (plate 1, figures 7, 9).

Occurrence. Rare in the Pennsylvanian (see earlier). Common and probably cosmopolitan in the Cisuralian (this study). Rare in the Middle and Late Permian (Zanin Buri, 1965; Mohtat Aghai and Vachard, 2005).

Epiastopora alpina (Kochansky and Herak, 1960) n. gen. n. comb.

Figure 19.5, 19.10, Figure 20.5, Figure 21.8, Figure 22.2, 22.5

p. 1937 Epimastopora nov. sp. Pia, p. 828, pl. 97, fig. 4 (large specimen, left).

* 1960 Epimastopora alpina Kochansky and Herak, p. 78 , pl. 4, figs. $1-4$. 

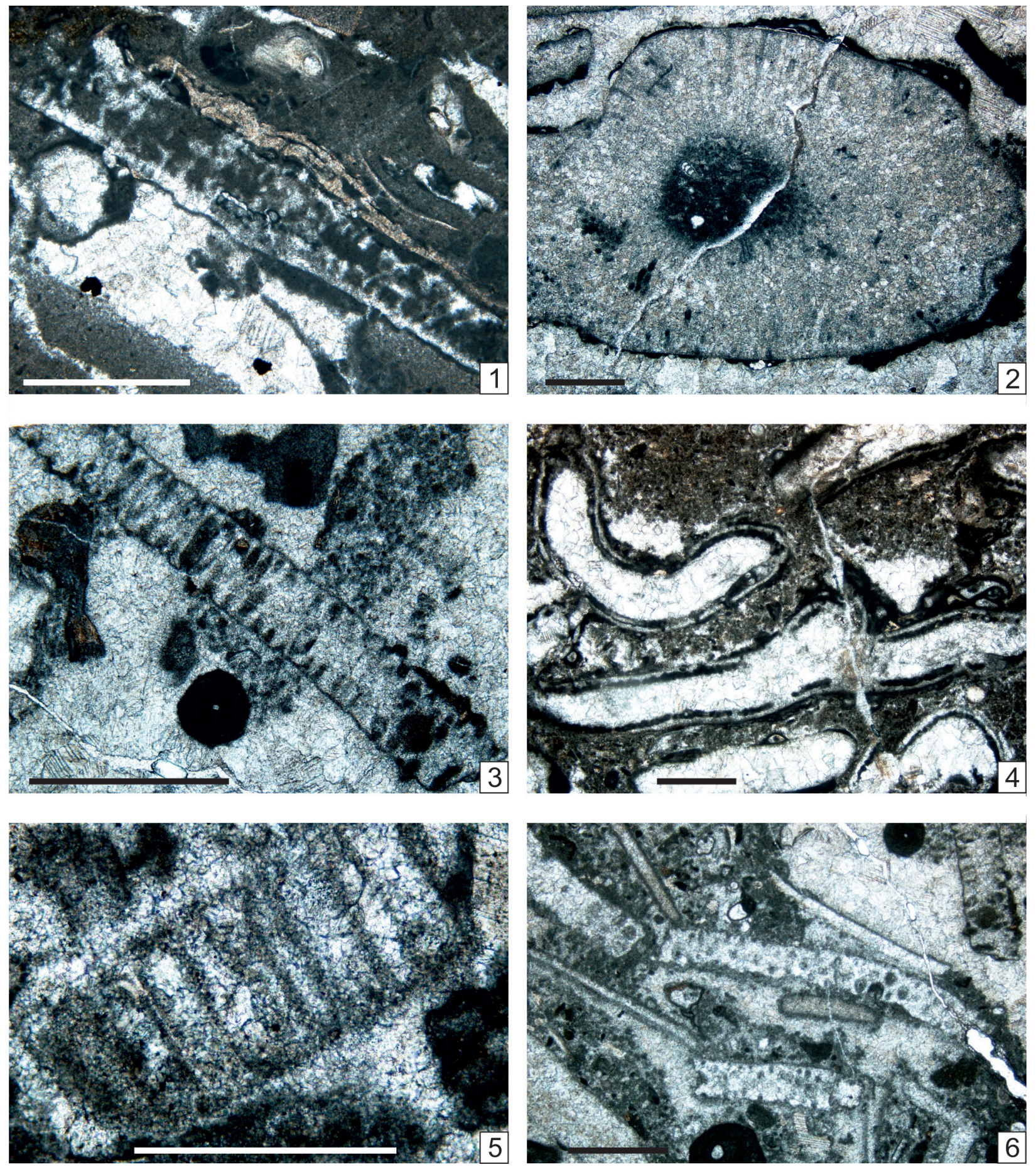

FIGURE 20. 1. Calcipatera schoenlaubi n. sp. Paratype encrusted by Claracrusta catenoides (Homann, 1972) emend. Vachard in Vachard and Montenat, 1981. Sample TM8_1. 2. Anthracoporella spectabilis Pia, 1920. Sample TM7_4. 3. Epimastopora likana Kochansky and Herak, 1960 emend. herein. Sample TM7_1a. 4. Eugonophyllum magnum (Endo, 1951) emend. Konishi and Wray, 1961. Sample ZK201_A. 5. Epiastopora alpina (Kochansky and Herak, 1960) n. gen. n. comb. Fragment of longitudinal section. Sample GB54_7. 6. Epimastopora cf. iwaizensis Endo, 1953a. Sample TM7_1b. Scale bars: $0.5 \mu \mathrm{m}$ (Figure 20.5); all others $=1 \mu \mathrm{m}$. 
1965 Epimastopora alpina; Herak, p. 214 (no illustration).

non 1965 Epimastopora alpina; Kordé, pl. 55, figs. 1, 2 (possible gymnocodiaceans).

1966 Epimastopora alpina; Flügel, p. 35-37, pl. 6, figs. 4, 5 (with five references in synonymy).

.1968 Epimastopora alpina; Flügel, p. 55, 56 (no illustration).

1970a Epimastopora alpina; Kochansky-Devidé, p. 214, 241, pl. 23, figs. 7, 8, 11.

?1972 Epimastopora alpina; Homann, p. 193-197, pl. 4, fig. 25, pl. 5, fig. 39.

1976 Epimastopora alpina; Emberger, p. 38 (no illustration with 16 references).

1978 Epimastopora alpina; Kulik, p. 195-197, pl. 5, figs. 1-3 (with seven references).

1979 Epimostopora (sic) alpina; Flügel, p. 572, pl. 1, fig. 6 (= E. spp.).

p1980 Epimastopora; Flügel, pl. 8, fig. 1 (top only; other ones, in center, are E. ex gr. likana).

p.1980 Epimastopora alpina Pia; Flügel, pl. 6, figs. 3, 4, (non pl. 8, fig. 3 = Epimastopora and Globuliferoporella; nec pl. 10, fig. 5 = Epiastopora flugeli).

p1980 Epimastopora alpina; Flügel and FlügelKahler, p. 142-144, pl. 5, figs. 3-5, pl. 7, fig. 9 (non figs. 1, 2 = Epimastopora likana, nec figs. $6,7=$ other genera; pl. 7, fig. $9=$ Epimastopora likana) (with six references).

1980 Epimastopora bodoniensis Rácz; Flügel and Flügel-Kahler, p. 146, pl. 6, fig. 1 (with three references in synonymy).

?1980 Epimastopora camasobresensis Rácz; Flügel and Flügel-Kahler, p. 146, pl. 6, fig. 5 (with one reference in synonymy).

1980 "Epimastopora" alpina; Vachard, pl. 23, fig. 1. ?1982 Epimastopora alpina; Mu, p. 224, pl. 5, fig. 10.

1985 Epimastopora alpina; Mu, p. 224, pl. 15, figs. $5,6$.

?.1991 Paraepimastopora; Riding and Guo, fig. 5.

?.1995 Epimastopora sp.; Forke, p. 240, pl. 15, fig. 4.

?1996 Epimastoporella japonica (Endo); Mamet, pl. 1, figs. 9-12.

1997 Epimastopora alpina Pia; Sokač et al., p. 145 (no illustration).

2000 Epimastoporella alpina Kochansky et Herak ex Roux (sic); Granier and Grgasović, p. 5960 (no illustration, with 27 references in synonymy).

v.2001a Epimastopora alpina; Vachard and Krainer, p. 151 (no illustration).

v.2001b Epimastopora alpina; Vachard and Krainer, p. 172 (no illustration). v. 2003a Epimastopora alpina; Krainer et al., p. 10, 19, table 1 p. 18 , pl. 5, figs. 7, 8, 10, 17, 19.

?.2004 Epimastopora grainstone; Flügel, pl. 60, fig. 4, pl. 105, fig. 2.

v2009 Epimastopora alpina; Krainer et al., p. 13, pl. 4, fig. 14.

v2012 Epimastopora alpina; Kolodka et al., p. 138, fig. 8a.

v2012 Epimastopora ex gr. alpina; Vachard et al., p. 235, 239, pl. 1, fig. 3.

v2013a Epimastopora ex gr. alpina; Vachard et al., p. 7 (no illustration).

?v.2015 Epimastopora ex gr. E. alpina; Krainer et al., figs. 19.10, 20.10.

v.2015 Epimastopora ex gr. E. alpina; Lucas et al., figs. 12.3?, 21.16, 40.9, 40.25.

v2017a Epimastopora alpina; Krainer et al., p. 20 (no illustration).

Description. The rectangular longitudinal section of the laterals is characteristic. Length of remains $=$ $850-8,000 \mu \mathrm{m}$; width of remains $=200-410 \mu \mathrm{m}$; diameter of pores $(=$ laterals $)=80-250 \mu \mathrm{m}$; interpore width $=20-85 \mu \mathrm{m}$. These dimensions are rather small for an E. alpina (compare with those indicated by Kulik, 1978).

Occurrence. Kasimovian-Artinskian, cosmopolitan. Rare in the early Capitanian of Iran (MohtatAghai and Vachard, 2005; Kolodka et al., 2012). In the Carnic Alps: Auernig Fm (Vachard and Krainer, 2001a); Rattendorf Group and Trogkofel Formation; Forni Avoltri (Flügel, 1968, 1979, 1980; Vachard and Krainer, 2001b). This study: Zweikofel Fm (samples GB38_6; GB54_7; GB58_6; GB60_8; GB60_9; ZK99c_11; ZK188_1_A); Zottachkopf Fm (samples TKW13 2b; TKW TNA1_2_2; TNC5_3_2; TNC7_2; Z5_1; Z6B_5).

Epiastopora fluegeli (Kulik, 1978)

Figure 19.11

*1978 Epimastopora flügeli Kulik, p. 198, pl. 5, figs. 4-6 (with one reference in synonymy).

p.1980 Epimastopora alpina Pia; Flügel, pl. 10, fig. 5 (non pl. 6, figs. 1, 2 = rare Epimastopora and rare Epimastopora likana; nec pl. 8, fig. $3=$ Epimastopora and Globuliferoporella).

1980 Epimastopora flügeli; Flügel and FlügelKahler, p. 146, pl. 6, fig. 2 (with one reference in synonymy).

2000 Epimastopora fluegeli; Granier and Grgasović, p. 56 (no illustration, with two references in synonymy).

v2009 Epimastopora fluegeli; Krainer et al., pl. 4, fig. 18.

non v2013 Gyroporella aff. fluegeli; Parvizi et al., p. 157, fig. $7 i$. 
v2017a Epimastopora fluegeli; Krainer et al., p. 20 (no illustration).

Description. Epiastopora fluegeli differs from $E$. alpina by more regularly arranged and broader laterals (= pores) and thinner interpores. Length of remains $=2,000-8,000 \mu \mathrm{m}$; width of remains $=$ 200-400 $\mu \mathrm{m}$; diameter of pores (= laterals) $=80-$ $200 \mu \mathrm{m}$; interpore width $=10-40 \mu \mathrm{m}$.

Occurrence. Early Permian of Russia, Italy, and New Mexico. In this study: Zweikofel Fm (sample GB38_6) and Zottachkopf Fm (samples TKW13B_8 and TNA18_2_1a).

Genus GLOBULIFEROPORELLA Chuvashov, 1974 emend. herein

Synonyms. Epimastopora sensu Kordé, 1951 and sensu Roux, 1979 (see discussion earlier); Gyroporella (part.).

Emended type species. Globuliferoporella piai (Kordé, 1951) nom. nov. (= Epimastopora piai Kordé, 1951 = Globuliferoporella symmetrica (Johnson) sensu Chuvashov, 1974 non Gyroporella symmetrica Johnson, 1946); by subsequent designation herein.

Emended diagnosis. Epimastoporellacean with dumb-bell-shaped laterals, perpendicular to both surfaces of the thallus.

Occurrence. Late Kasimovian-Gzhelian Bashkortostan (Zagorodnyuk, 1979; Chuvashov and Anfimov, 1988). ?Gzhelian of northern Spain (Mamet and Villa, 2004). Cisuralian of Greece, Slovenia, Tibet, South China, Sumatra, Urals, Canadian Arctic, Bolivia (compiled here). Orenburgian-Artinskian of the Carnic Alps (Vachard and Krainer, 2001a, and this work). ?Murgabian of Turkey (Flügel, 1990). Permian of Western Sicily (Flügel et al., 1991).

Globuliferoporella piai (Kordé, 1951) n. comb. Figure 19.12-13, 19.15, Figure 21.1, 21.7?, 21.811

*1951 Epimastopora piai Kordé, p. 177, pl. 1, figs. 1-3.

1963 Epimastopora piai; Maslov et al., pl. 17, fig. 6.

1966 Globuliferoporella symetrica (sic; the correct Latin spelling is symmetrica) Johnson; Flügel, p. 39-41, pl. 7, figs. 1, 2.

1968 Globuliferoporella symetrica (sic); Flügel, p. 55, 56 (no illustration).

?1970a Epimastopora piai; Kochansky-Devidé, p. 214, 241, pl. 23, fig. 10 (or E. piae)

?1972 Globuliferoporella symetrica (sic); Homann, p. 207-210, pl. 6, fig. 43. non.1973 Epimastopora piai; Kitaev, pl. 4, fig. 6 (an Epiastopora).

1974 Globuliferoporella symetrica (sic); Chuvashov p. 27, pl. 12, figs. 1-7 (sic 1-8).

1978 Globuliferoporella symetrica (sic); Kulik, p. 205, pl. 7, figs. 3-6.

1979 Globuliferoporella symetrica (sic); Flügel, p. 572, pl. 1, fig. 6.

1979 Pseudoepimastopora likana (Kochansky (sic) et Herak); Zagorodnyuk, p. 7, pl. 1, fig. 5.

1979 Epimastopora symetrica (sic); Mamet et al., pl. 3, fig. 8.

non 1979 Globuliferoporella symetrica (sic); Zagorodnyuk, p. 7-8, pl. 1, fig. 7, pl. 2, fig. 1 (= G. angulata).

v non1980 Gyroporella symmetrica; Vachard, p. 351, 352, 353 (= a true Gyroporella).

?.1980 Globuliferoporella symetrica (sic); Flügel, pl. 9, fig. 1.

non 1980 Epimastopora piae Bilgütay; Flügel, pl. 6, figs. 3, 4 (an Epimastopora).

p1980 Globuliferoporella symetrica (sic); Flügel and Flügel-Kahler, p. 153-154, pl. 7, figs. 1, 3 (non fig. 2 = Globuliferoporella angulata).

1985 Globuliferoporella symetrica (sic); Mu, p. 145, pl. 13, figs. 1a, 1b, 2, 7, 8.

p1987 Epimastopora symetrica (sic); Mamet et al., p. $36-37$, pl. 7 , figs. 8-11, pl. 18, fig. 1, 5-16 (non figs. $2-4=$ tangential section of Epiastopora).

1988 Epimastopora symetrica (sic); Chuvashov and Anfimov, p. 64, pl. 26, figs. 5, 6.

1990 Globuliferoporella symetrica (sic); Flügel, pl. 2, fig. 2.

?1991 Epimastopora; Riding and Guo, fig. 5.

1993 Globuliferoporella symetrica (sic); Chuvashov et al., pl. 14, figs. 8-9.

?1996 Epimastopora sp.; Mamet, p. 121, pl. 1, fig. 12.

2000 Epimastopora piai Kordé; Granier and Grgasović, p. 57 (no illustration, with four references in synonymy).

2000 Epimastopora symetrica (sic) (Johnson); Granier and Grgasović, p. 58-59, 67 (no illustration, with 24 references in synonymy).

v 2001b Globuliferella piai Kordé; Vachard and Krainer, pl. 3, fig. 8.

?2004 Epimastopora symetrica (sic); Mamet and Villa, p. 62, fig. 8p (with two additional references in synonymy to those of Granier and Grgasović, 2000).

Description. Thallus length $=800-1,700 \mu \mathrm{m}$; thallus width $=150-200 \mu \mathrm{m}$; maximal diameters of laterals $=30-60-(75) \mu \mathrm{m}$; central diameter of laterals $=10-20-(30) \mu \mathrm{m}$; interpores $=10-25 \mu \mathrm{m}$. 

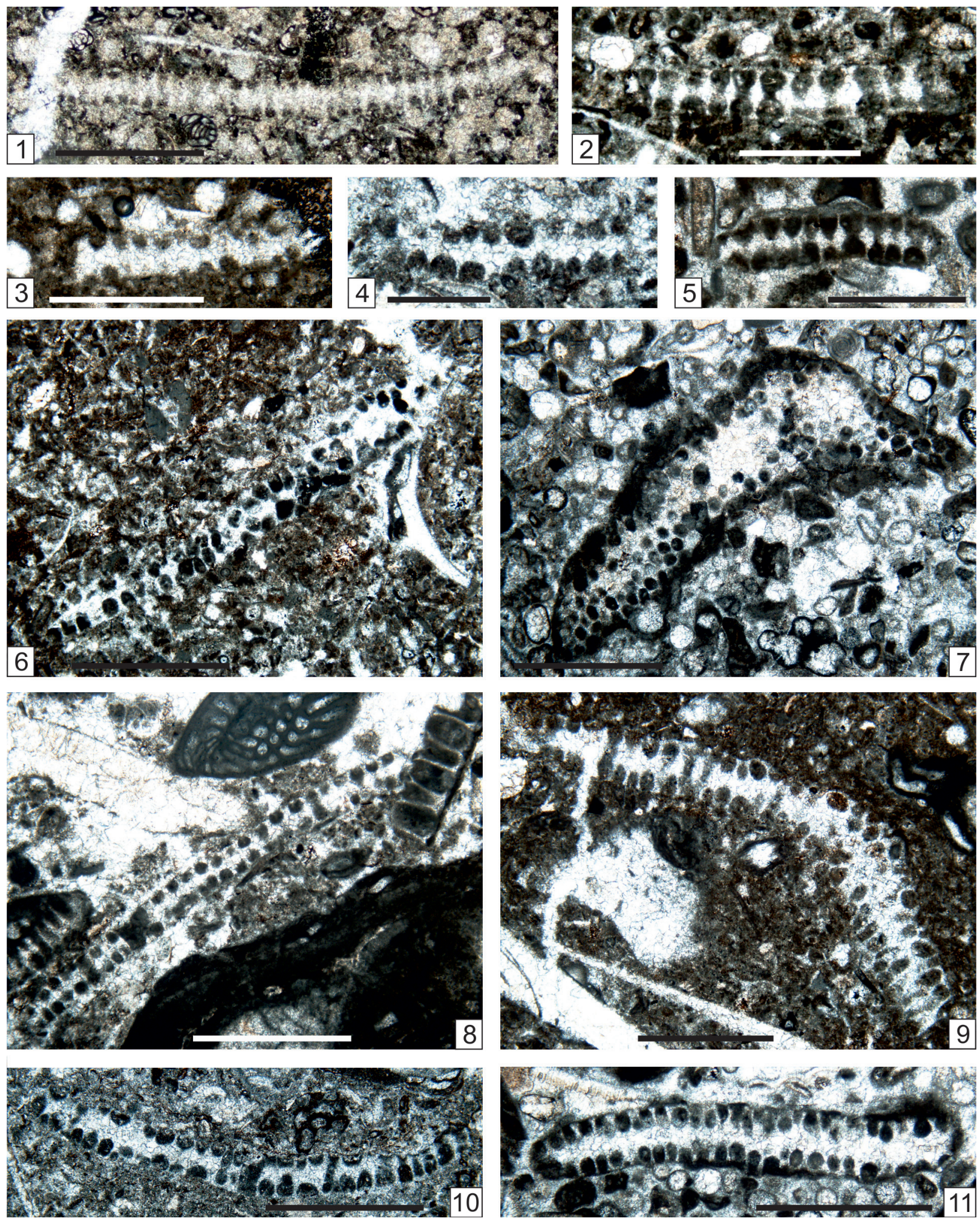

FIGURE 21. 1, 7?, 8-11. Globuliferoporella piai (Kordé, 1951). 1. Longitudinal section. Sample GB67_7a. 7? Tangential section. Sample Z10B_2. 8. Longitudinal section with Epiastopora alpina (Kochansky and Herak, 1960) n. gen. n. comb. (top right). Sample Z6B_5. 9. Oblique section. Sample TKW12B_2. 10. Longitudinal section. Sample TKW9_1. 11. Longitudinal section. Sample Z10_1. 2-5, 6? Globuliferoporella angulata Chuvashov, 1974. Three oblique longitudinal sections. 2. Sample GB153_A. 3. Sample ZK96_3. 4. Sample TKW9B_1. 5. Sample ZK187_2. 6. Sample TKW12_2b. Scale bars: $0.5 \mu \mathrm{m}$. 
Remarks. In reality, Gyroporella symmetrica is a true Gyroporella and is Capitanian in age (see Parvizi et al., 2013, figure 6f). Globuliferoporella is a well-defined genus, even if it was confused with Epimastopora by Roux (1979), Granier and Grgasović (2000) and Mamet and Villa (2004). Consequently, a type species must be defined for Globuliferoporella. The oldest described species presenting the characters of Globuliferoporella is Epimastopora piai, subsequently designed as type species here.

Occurrence. ?Gzhelian of northern Spain (Mamet and Villa, 2004). Cisuralian of Urals, Canadian Arctic, South China, Carnic Alps, Slovenia, Bolivia (compiled here). ?Murgabian of Turkey (Flügel, 1990). Schulterkofel and Zweikofel formations (Flügel, 1968, 1979); Trogkofelkalk of Karawanken Mountains and Forni Avoltri (Flügel, 1966); Garnitzenbach, Grenzland Fm (Vachard and Krainer, 2001b; sample GB5). This study: Zweikofel Fm (samples GB67_7a, GB136_2?; GB153_A; ZK96_3; ZK97_19; ZK184_1; ZK187_2; ZK188_1_A; ZK191a_12; ZK201_A); Zottachkopf Fm (samples TKS2_1_4; TKS4_3; TKW9_1; TKW9B_1; TKW10_2B; TKW10_2c; TKW12_2b; TKW12B_2; Z6B_5; Z10_1; Z10B_1; Z10B_2?; ZT1_4); and Trogkofel Fm (sample TK55_1).

Globuliferoporella angulata Chuvashov, 1974

Figure 21.2-5, 21.6?

*1974 Globuliferoporella angulata Chuvashov, p. 27-28, pl. 12 , figs. 8,9 , pl. 13 , figs. $1-8$ (sic: 7 ; in the text).

.1979 Globuliferoporella symetrica (sic) (Johnson); Zagorodnyuk, p. 7-8, pl. 1, fig. 7, pl. 2, fig. 1

1979 Epimastopora (= Globuliferoporella); Mamet et al., pl. 3, fig. 7 (part.: right; non fig. 6 left; nec fig. 7 = Epiastopora).

p.1980 Globuliferoporella angulata; Flügel and Flügel-Kahler, p. 153-154, pl. 7, fig. 2 (non figs. 1, 3 = Globuliferoporella piai).

?.1982 Globuliferoporella angulata; Mu, p. 226, pl. 9, fig. 10.

1989 Globuliferoporella angulata; Vachard in Fontaine and Gafoer, pl. 6, figs. 10, 11, pl. 9, fig. 2.

1989 Globuliferoporella angulata; Nguyen Duc Tien, pl. 18, figs. 5, 6-8.

v1993b Globuliferoporella angulata; Vachard et al., pl. 1, fig. 3.

v?1993b Pseudoepimastopora shachtauensis Kulik; Vachard et al., pl. 1, fig. 5.

?1996 Epimastopora symetrica (sic); Mamet, p. 121, pl. 1, figs. 13, 14.
2000

Epimastopora angulata (Chuvashov) Roux; Granier and Grgasović, p. 55, 67 (no illustration, with five references in synonymy).

Description. Length $=800-1600 \mu \mathrm{m}$; width $=150$ $330 \mu \mathrm{m}$; pores $=40-150 \mu \mathrm{m}$; interpores $=20-30$ (50) $\mu \mathrm{m}$.

Occurrence. Late Pennsylvanian of Bashkortostan; Cisuralian of the Urals, Carnic Alps, Greece, Tibet, Sumatra and Bolivia. In the Carnic Alps: Forni Avoltri and Trogkofel (Flügel and FlügelKahler, 1980) and this study: Zweikofel and Zottachkopf formations (samples GB67_7a, GB153_A; TKW9B_1; TKW12_2b; ZK96_3; and ZK187_2).

\section{Globuliferoporella? sp.}

Figure 24.13

1991 Epimastopora sp.; Riding and Guo, pl. 1, fig. 5.

Description. A unique specimen could correspond to an apex or a base of Globuliferoroporella due to its circular transverse section of thallus and the form of its laterals, but an assignment to another, probably unpublished genus, is possible. Thallus width $=1,050 \mu \mathrm{m}$; cortical zone thickness $=300$ $\mu \mathrm{m}$; maximal diameter of laterals: $70 \mu \mathrm{m}$.

Occurrence. Basal Trogkofel Formation (sample Z19_3).

Tribe MACROPORELLAE Pia, 1920 emend. Bassoullet, Bernier, Deloffre, Génot, Jaffrezo and Vachard, 1979 Genus MACROPORELLA Pia, 1912

Type species. Macroporella dinarica Pia, 1912; by original designation.

Description. Thallus aspondyl, cylindrical not ramified. Laterals simple, acrophore.

Remarks. Nice specimens have been illustrated from Trogkofel limestone by Riding and Guo (1991); our material is less well preserved and cannot be specifically determined.

Occurrence. Late Moscovian (with the group Macroporella ginkeli Rácz, 1966a) of Spain and the Urals (Russia); Early Permian of Montenegro (Kochansky-Devidé and Milanović, 1962); Middle Permian (with the $M$. apachena Johnson, 1951, $M$. maxima Endo, 1952, and M. siamensis Endo, 1969-groups); USA (Johnson, 1951); Japan (Endo, 1952); Thailand (Endo, 1969); South China, at the base of the Maokouan regional stage (Lai et al., 2008); Armenia (Kordé, 1965); Carnic Alps (Flügel and Flügel-Kahler, 1980; Riding and Guo, 1991; this study); Tunisia (H. Termier et al., 1977); Philippines (Kiessling and Flügel, 2000); Turkey (Angiolini et al., 2007); Thailand (Endo, 1969; Vachard et 

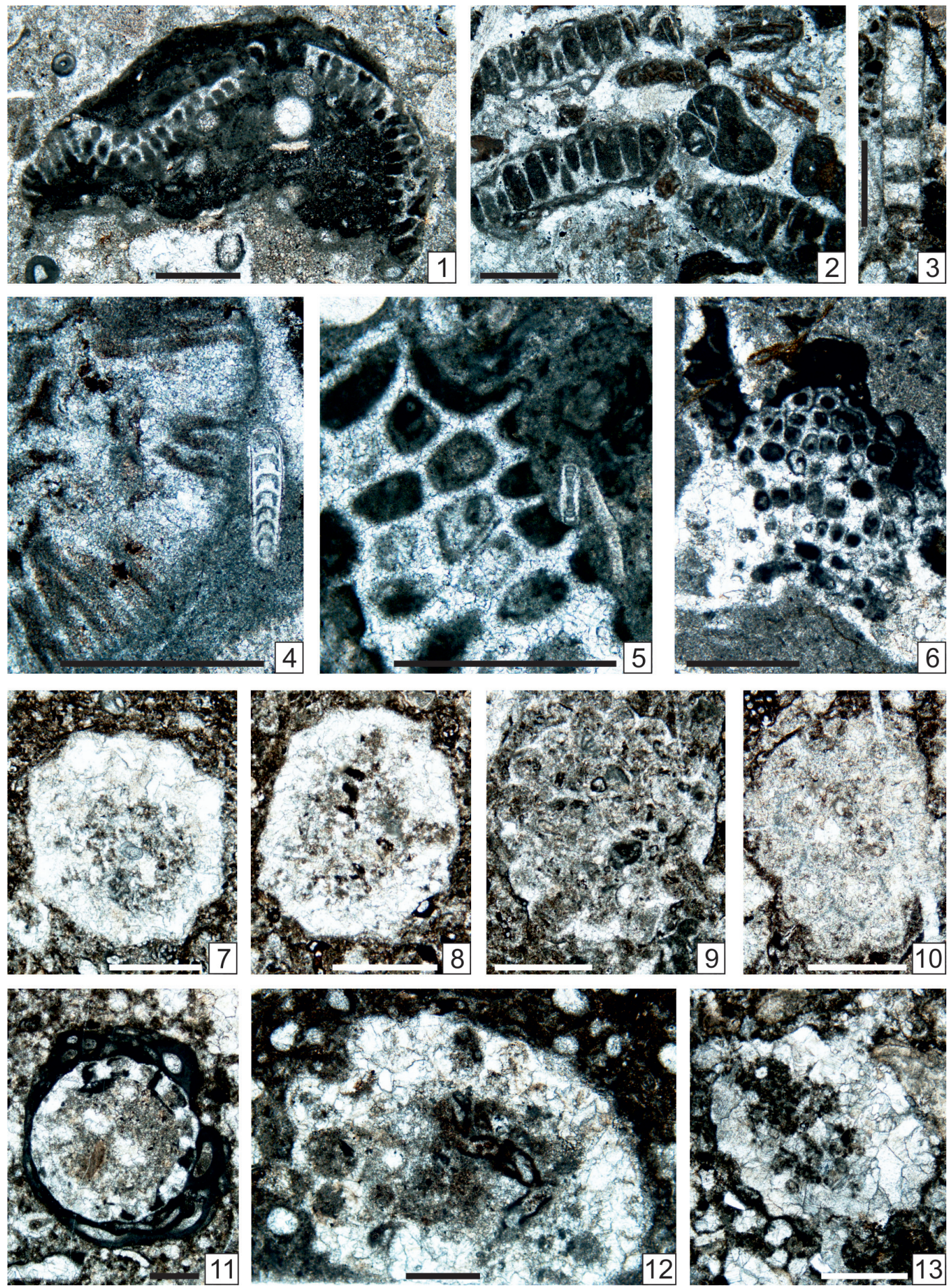

FIGURE 22. 1. Anthracoporella spectabilis Pia, 1920 emend. De Castro, 2002. Deformed longitudinal section. Sample Z3_2. 2, 5. Epiastopora alpina (Kochansky and Herak, 1960). 2. Several sections. Sample GB38_6. 5. Transverse section with Pseudovidalina sp. Sample TKW13_2b. 3, 6? Epimastopora likana Kochansky and Herak, 1960 emend. herein. 3. Broken longitudinal section. Sample ZK97_19. 6? Tangential section. Sample TNC5_3. 4. Nanjinophycus? $\mathrm{sp}$. Transverse section with numerous, bifurcated, acrophore to phloiophore laterals. Sample TNA16 1_2. 7, 8. Mizzia cornuta Kochansky and Herak, 1960. Two recrystallized transverse sections. 7. Sample GB130_1. 8. Sample GB130_3. 9-11. Mizzia velebitana Schubert, 1908. Three transverse sections. 9. Sample GB129_3. 10. Sample GB67_10. 11. Encrusted by Palaeonubecularia sp. Sample ZK207_7. 12?, 13? Mizzia yabei (Karpinsky, 1909) emend. Pia, 1920. Two oblique sections. 12. Sample ZK96_11. 13. Sample GB163_5. Scale bars: $0.5 \mu \mathrm{m}$. 
al., 1992). Late Permian of Greece (Vachard et al., 1993a, 2003). Middle-Late Triassic with typical Macroporella ex gr. alpina (e.g., Bucur and Enos, 2001).

Macroporella cf. siamensis Endo, 1969 Figure 23.1-2

To compare with:

*1969 Macroporella siamensis Endo, p. 53, pl. 12, figs. 6-11.

1976 Macroporella siamensis; Emberger, p. 56 (no illustration).

1980 Macroporella; Flügel, pl. 14, fig. 3 (poorly visible).

?1980 Macroporella aff. tenuimarginata Endo; Flügel and Flügel-Kahler, p. 136, pl. 4, figs. 1, 6.

?1981 Macroporella sp.; Mu, p. 45, pl. 4, fig. 1.

?1991 Macroporella sp.; Riding and Guo, fig. 4 (or another species).

Description. Our rare specimens have the same proportions as $M$. siamensis but are smaller. Length $=4,000 \mu \mathrm{m}$; outer diameter $=1,740-3,470$ $\mu \mathrm{m}$; inner diameter $=960-1,900 \mu \mathrm{m} ;$ pores $=50$ $70 \mu \mathrm{m}$ interpores $=100-160 \mu \mathrm{m}$.

Occurrence. Kungurian/Roadian of Thailand (Endo, 1969). In the Carnic Alps, in the Trogkofel limestone. Flügel (1980), Flügel and Flügel-Kahler (1980) and Riding and Guo (1991) have published some illustrations of other species of Macroporella; our rare specimens were found in the Trogkofel Fm (samples GBT3_3 and GBT3_4).

Tribe GYROPORELLEAE Pal, 1976 nom. translat. Bassoullet, Bernier, Deloffre, Génot, Jaffrezo, and Vachard, 1979, emend. herein

Emended diagnosis. Thallus cylindrical to clubshaped. Aspondyl, almost euspondyl. Laterals numerous, closely arranged, vesiculifer with a form varying from drumstick (i.e., with two parts: one cylindrical and the distal spherical) to Scottishchardon-shaped (i. e., with three parts: the innermost short cylindrical, acrophore; the central second one spherical and inflated; the outermost conical truncated). The pores are circular. The central stem is relatively frequently individually calcified.

Occurrence. Middle Pennsylvanian-Jurassic, probably cosmopolitan.

Genus GYROPORELLA Gümbel, 1872, emend. Kochansky-Devidé, 1970b

Type species. Gyroporella vesiculifera Gümbel, 1872.

Synonyms. Permoperplexella Elliott, 1968a; ?Pseudogyroporella Endo, 1961a; Thailando- porella Endo, 1969; Mizzia? sp. sensu Wilson, 1975; Atractyliopsis sensu Riding and Guo, 1991; Physoporella part. (sensu Endo, 1961a); Epimastopora (part.); Globuliferoporella (part.).

Description. Thallus aspondyl, cylindrical not ramified. Laterals simple, cladophore.

Remarks. The variability of the species in the Permian contributed to the creation of diverse "genera" as Permoperplexella or Pseudogyroporella. Kashirian species are yet relatively diversified, and the origin is probably located in the Bashkirian. The reconstructions of Pia (1920), Roux (1985, text-figure 17) and Mamet (1991, figure Xq) showing an euspondyl thallus are misinterpreted.

Although attributed to different families, Gyroporella and Mizzia belong probably to the same lineage (Ghazzay-Souli et al., 2015). Transitional forms are Gyroporella dissecta Chuvashov, 1974 and Mizzia longiporosa Endo, 1961d sensu Mu, 1982.

Occurrence. Kashirian of Croatia. Late Desmoinesian of New Mexico. Late Moscovian of southern Urals and northern Spain. Late PennsylvanianPermian of the Urals, northern Spain, Croatia, Montenegro, Greece, Carnic Alps, Turkey, Iraqi Kurdistan, Iran, Kazakhstan, Afghanistan, Thailand, Malaysia, South China, Vietnam, Cambodgia, Sumatra, Japan, Russia (Urals), USA (Texas, New Mexico, Washington); Guatemala, and Canada (British Columbia, Canadian Arctic) (compiled in this study). Triassic of the Carnic Alps. Questionable in the late Moscovian of Thailand (Fontaine et al., 1997). LAD in the earliest Jurassic (Deloffre, 1988).

\section{Gyroporella sp.}

Figure 25.9?, Figure 27.1

Description. Even if many species of Gyroporella have been mentioned in the Carnic Alps (Austria/ Italy) and adjacent areas of Slovenia and Croatia (see the next paragraph), our material contains very rare representatives of this genus, which are, at a consequence, remained in open nomenclature. Only two sections could belong to this genus (Figure 25.9 (bottom right); which is possibly also a Mizzia yabei; see later) and a transverse section (Figure 27.1), the measurements of which are: $D=$ $1,500 \mu \mathrm{m} ; \mathrm{d}=750 \mu \mathrm{m}$; initial diameter of laterals $=$ $100 \mu \mathrm{m}$; distal part of laterals: $200 \mu \mathrm{m}$; interpores $=$ $100 \mu \mathrm{m}$.

Remarks. The species of Gyroporella, mentioned in the Carnic Alps (Austria/ltaly) and adjacent areas of Slovenia and Croatia, were:

1) Gyroporella cf. G. nipponica Endo and Horiguchi by Flügel, 1968, p. 56 (no illustration), 

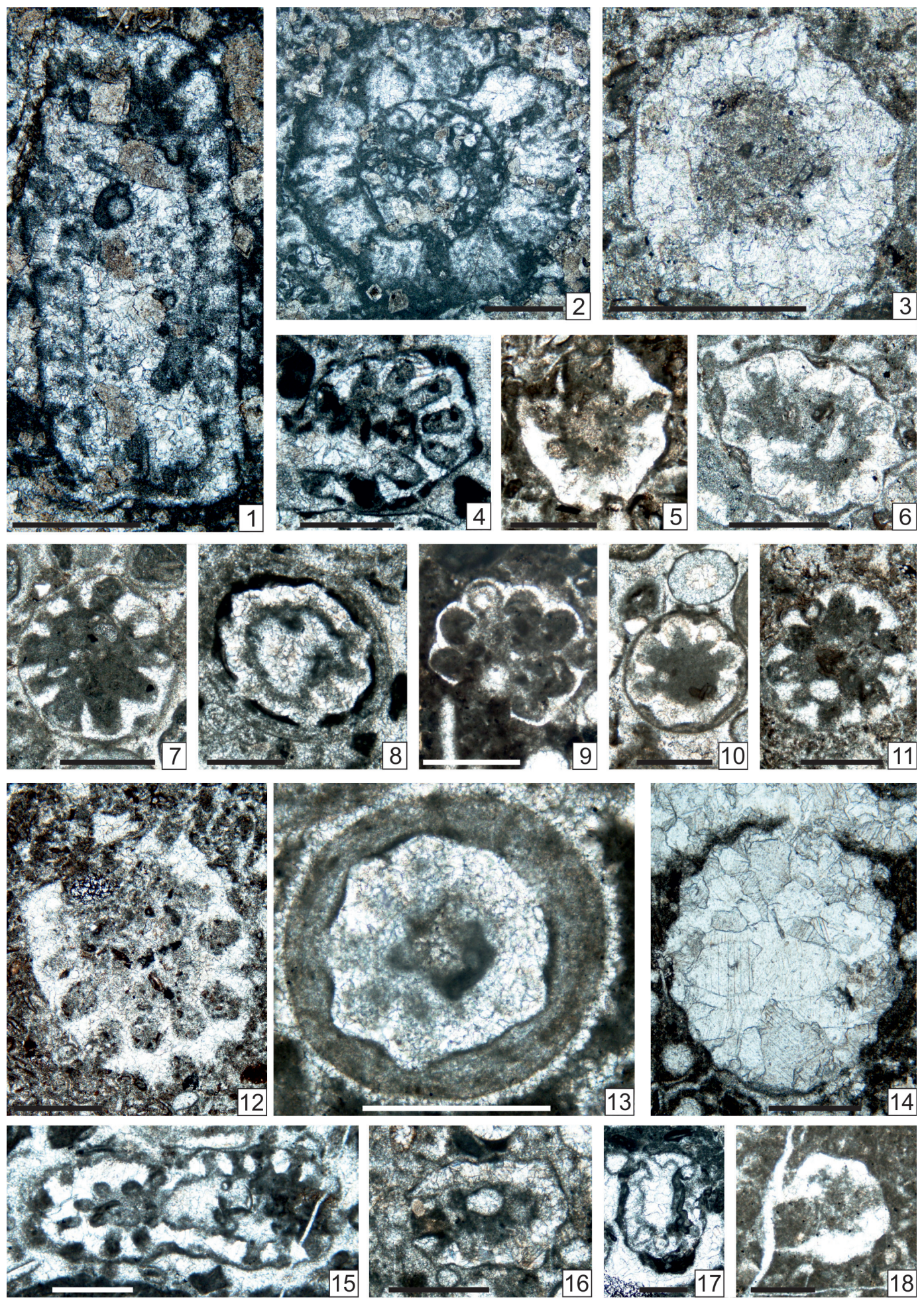

FIGURE 23. 1, 2. Macroporella cf. siamensis Endo, 1969. Longitudinal section. Sample GBT3_3. 2. Transverse section. Sample GBT3 4. 3, 5, 6, 8, 13, 18. Mizzia cornuta Kochansky and Herak, 1960. Several oblique transverse sections. 3. Sample GB40_5. 5. Sample GB40_6. 6. Sample GB70s_3. 7. Sample GB72_3. 8. Sample GB105_5. 13. Sample GB106_A. 18. Sample GBT1_4. 7, 9-12, 14? Mizzia velebitana Schubert, 1908. Several oblique transverse sections. 9. Sample GB109_2. 10. Sample GB111_4. 11. Sample GB129_6. 12. Sample GB66_11. 14? Sample GB156_9. 4, 15-17. Mizzia yabei (Karpinsky, 1909) emend. Pia, 1920. Several oblique sections. 4. Sample GB43_5. 15. Sample TK12_4. 16. Sample ZK202_6. 17. Sample Z14_1_2. Scale bars: Figures 23.1-23.3 = $1 \mu \mathrm{m}$; all others = $0.5 \mu \mathrm{m}$. 
1979 p. 572 (no illustration); KochanskyDevidé, 1970a, p. 216, 242, plate 24, figures 1-6 (which are in reality probably several genera including Mizzia and Pseudoepimastopora emend.); Flügel and Flügel-Kahler, 1980, p. 134-135, plate 4, figures 2, 4, 9; Vachard and Krainer, 2001a, p. 151 (no illustration) and 2001b, p. 172, plate 1, figure 1.

2) Gyroporella microporosa Endo, by Kochansky-Devidé, 1970a, p. 217, 242, plate 7, figure 7; Flügel, 1979, p. 572 (no illustration).

3) Gyroporella? tenuimarginata KochanskyDevidé, by Kochansky-Devidé, 1970a, p. 217, 242, plate 7, figure 8; Flügel, 1979, p. 572 (no illustration).

4) Gyroporella intusannulata Kochansky-Devidé; Kochansky-Devidé, 1970a, p. 217-218, 242, plate 25, figures 1-9; Flügel, 1979, p. 572 (no illustration).

5) Gyroporella igoi Endo; Flügel, 1979, p. 572 (no illustration).

6) Gyroporella longithalla Endo; Flügel, 1979, plate 1, figure 7; Flügel and Flügel-Kahler, 1980 , p. 132, 134, plate 4, figure 5.

7) Gyroporella cf. likana Kochansky-Devidé; Flügel and Flügel-Kahler, 1980, p. 131-132 plate 4, figure 8.

8) Gyroporella dissecta Chuvashov; Vachard and Krainer, 2001a, p. 151 (no illustration).

9) Gyroporella sp., by Kochansky-Devidé, 1970a, p. 218-219, plate 7, figure 9; Riding and Guo, 1991, figure 10; Flügel, 2004, plate 101 (full page).

10) Atractyliopsis sp.; Riding and Guo, 1991, plate 1 , figure 3 .

Occurrence. In the Carnic Alps: Auernig Fm (Vachard and Krainer, 2001a); Schulterkofel Fm; Zweikofel Fm; Trogkofel Fm, Forni Avoltri (Flügel, 1968, 1979; Vachard and Krainer, 2001b). Seikofel, Sexten, Dolomites, Italy (Flügel, 2004). In this study: Zweikofel Fm (sample ZK204_A?) and Zottachkopf Fm (sample ZT1_6).

Genus PSEUDOEPIMASTOPORA Endo, 1960 emend. herein

Type species. Pseudoepimastopora pertunda Endo, 1960 emend. herein.

Emended diagnosis. Thallus ellipsoidal to ovoid. Laterals simple, almost euspondyl, perpendicular to the central cavity, with a perpendicular shape: with a complex form defined here as Scottishchardon, i. e., with three parts; the innermost is short, cylindrical, acrophore; the central second one is spherical and inflated; the outermost is conical truncated.
Remarks. We do not agree with Granier and Deloffre $(1994$, p. 58, 72) who considered Pseudoepimastopora as a nomen nudum. It is poorly defined, but perfectly valid, and consequently was to be revised. The principal taxonomic problem is that, erroneously, Endo (1960) and Johnson (1963) have described the shape of the laterals as similar to those of Epimastopora japonica; i.e., as to those of the genus Epimastopora emend. herein. This real shape of the laterals was correctly described in P.? impera Ràcz, 1966a in a taxon considered therefore as a questionable Pseudoepimastopora (sensu Endo or Johnson). Here, we valid the species $P$. pertunda by designation of the figure 5 as unique holotype (Endo designated initially two "holotypes": figures 3 and 5), and consequently, we valid definitively the genus Pseudoepimastopora. As already indicated by Granier and Deloffre (1994, p. 58), the consequence of such an emendation leads to consider Epimastoporella as a senior synonym of Pseudoepimastopora, and to discard definitively Epimastoporella from the literature. We re-established Epimastopora Pia, 1922, emend. Kochansky and Herak, 196, as the name for many "Epimastoporella". In consequence, Globuliferoporella corresponds currently to its original definition. In contrast, as, contrary to Granier and Deloffre (1994), we consider Tauridium as a possible senior synonym of Permocalculus, the genus Paraepimastopora Roux, 1979, becomes again perfectly valid (see earlier). Pseudoepimastopora in the sense of Homann (1972) is misinterpreted, and encompasses in reality Epimastopora species; similarly, Pseudoepimastopora sensu Flügel et al. (1991) is either Epimastoporella (plate 47, figure 7) or a phylloid alga Ivanovia or Eugonophyllum (plate 47, figure 5).

Pseudoepimastopora primaeva Chuvashov and Anfimov, 1988 (re-illustrated in Chuvashov et al., 1993, plate 3, figure 2), from the late Moscovian of the eastern slope of the western Urals, is possibly a transitional form between Gyroporella and Pseudoepimastopora emend. herein.

There are, in the literature, four interpretations for the groups of small spheres more or less linked by a microsparitic cement, which are generally assigned to the dasycladales: 1) the sporangia of acetabulariaceans (including the Mesozoic to Recent aciculariaceans or polyphysaceans, and perhaps Atractyliopsis Pia, 1937, emend. Accordi, 1956, sensu stricto and Atractyliopsis? sensu Cózar et al., 2014); 2) entire calcification of the central cavity of endospore genera (e.g., Aciculella Pia, 1930 non 1927 emend. Elliott, 1971; "Atractyli- 

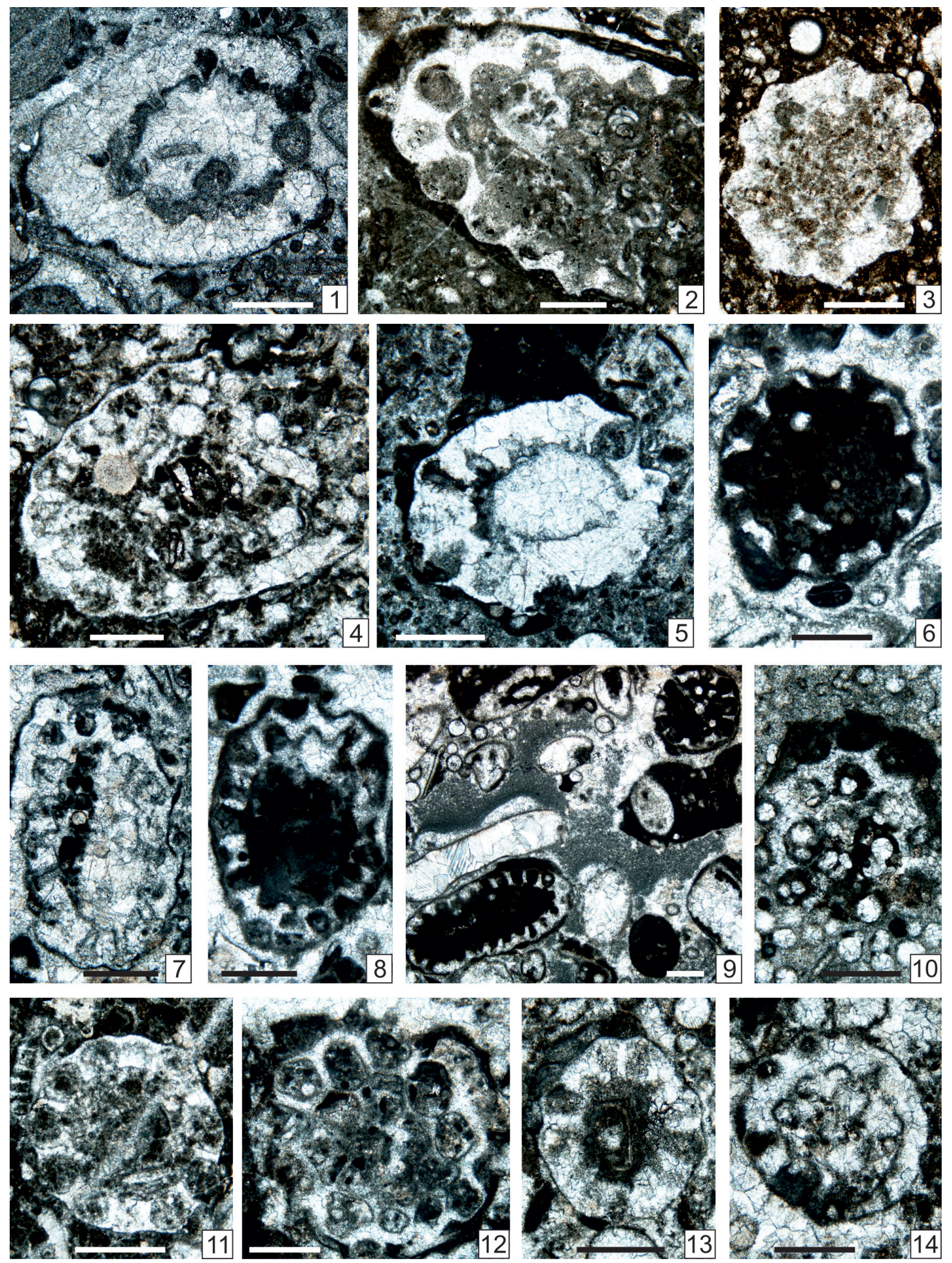

FIGURE 24. 1, 2, 5, 7, 8, 9 (bottom), 10. Mizzia yabei (Karpinsky, 1909) emend. Pia, 1920. 1. Oblique section. Sample GB43_5. 2. Oblique section. Sample GB71_1_1. 5. Oblique section. Sample Z13B_4. 7. Transverse section. Sample TSK12_2. 8. Transverse section. Sample TKS 12_3a. 9. Subaxial section (bottom, left). Sample ZK204_A. 10. Abraded tangential section. Sample ZK203_2. 3, 4, 6, 9 (top), 11-13, 14? Mizzia velebitana Schubert, 1908. 3. Transverse section. Sample GB146_2. 4. Oblique section. Sample GB163_10. 6. Transverse section superficially abraded. Sample TKS13_5. 9. Transverse section (top, right). Sample ZK204_A. 11. Transverse section. Sample GB175_11. 12. Tangential section showing the aspect of surface. Sample ZK94_5_4. 13. Transverse section. Sample ZK200_5. 14. Transverse section showing different stages of diagenesis. Sample ZK200_6. Scale bars: $0.5 \mu \mathrm{m}$. 
opsis" sensu Rich 1974, Mamet and Roux 1975b, 1978, and Devuyst 2006, non Pia 1937; and "Pseudoepimastopora" sensu Elliott, 1968a) whereas isolated spores can be visible in situ in not recrystallized central cavities (see Diplopora in Pia, 1920, Elliott, 1971, and $\mathrm{Mu}, 1982$; and here Anthracoporella (Figure 8.3), and see later "Algen Sporen"; 3) thalli of dasycladales with vesiculifer laterals with large distal part and short proximal part (e.g., Coelosporella Wood, 1940; Holosporella Pia, 1930; and Pseudoepimastopora emend. herein); 4) undeterminate groups of spherical bodies having often a dark microgranular wall (e.g., Ningbingellina Mamet, 1998; Ningbingellina sensu Devuyst, 2006; Floritheca Gaillot and Vachard, 2007; Aphanocapsites Maslov sensu Mamet and Préat, 2013; and Neoradiosphaeroporella Cózar and Vachard in Vachard et al., 2016).

Occurrence. Late Virgilian of New Mexico (Krainer et al., 2017a). Asselian-Artinskian of the northwestern margin of the Paleotethys (Montenegro, Turkey, Carnic Alps, Italy, Croatia, Serbia, Texas and New Mexico).

Pseudoepimastopora carnica (Flügel, 1966) n. comb., emend. herein

Figure 25.1-12, Figure 27.3, 27.6

*1966 Atractyliopsis carnica Flügel, p. 24, pl. 4, figs. 1-3, pl. 5, figs. 1-4.

1968 Atractyliopsis carnica; Flügel, p. 56 (no illustration).

1972 Atractyliopsis carnica; Homann, p. 192, p. 24, pl. 3, fig. 19, pl. 5, fig. 41.

1976 Atractyliopsis carnica; Emberger, p. 22 (no illustration) (with five references).

1979 Atractyliopsis carnica; Zagorodnyuk, p. 8, pl. 1, fig. 6.

1979 Ayractyliopsis (sic) carnica; Flügel, p. 572.

1979 Atractyliopsis (sic) carnica; Flügel, pl. 1, fig. 5.

?.1979 Pseudogyroporella mizziaeformis Endo; Flügel, p. 572 (no illustration).

1980 Atractyliopsis carnica; Flügel, pl. 5, figs. 1-5.

1980 Atractyliopsis sp.; Flügel, pl. 7, fig. 4, pl. 10, fig. 6.

1980 Atractyliopsis carnica; Flügel and FlügelKahler, p. 124-126, 128, pl. 2, figs. 1-8 (with three references in synonymy).

1981 Gyroporella nipponica Endo and Horiguchi; Ramovš and Kochansky-Devidé, pl. 1, fig. 4.

?1985 Poikiloporella sp.; Mu, pl. 15, fig. 1.

?.1991 Atractyliopsis; Riding and Guo, fig. 3.

2000 Atractyliopsis carnica; Granier and Grgasović, p. 16-17 (no illustration, with 18 references). v. 2001b Atractyliopsis carnica; Vachard and Krainer, pl. 3, fig. 11.

2004 Atractyliopsis carnica; Flügel, pl. 60, fig. 7.

2013 dasyclad algal fragments; Wahlman and Tasker, fig. 11E.

v. 2017 "Atractyliopsis" carnica; Lucas et al., p. 15 (no illustration).

v.2017a "Atractyliopsis" carnica Flügel; Krainer et al., p. $20,39,40$, pl. 25 , fig. 2 , pl. 27 , fig. 4 , pl. 37 , figs. $2-5$, pl. 41 , figs. $5,6,15-17$, pl. 43 , figs. $3,8,9,12,13$, pl. 44 , figs. $2,3,6,8$, pl. 52, fig. 4 .

Description. Length: up to $5,000 \mu \mathrm{m}$; outer diameter = 750-1,500 $\mu \mathrm{m}$; inner diameter $=450-1,200$ $\mu \mathrm{m}$; wall thickness $=150-250 \mu \mathrm{m}$; maximal width of pores $=170-250 \mu \mathrm{m}$; minimal width of pores $=$ 40-60 $\mu \mathrm{m}$; interpores $=30-40 \mu \mathrm{m}$. It differs from $P$. pertunda Endo, 1960 by the shape of the laterals.

Occurrence. Kasimovian of Bashkortostan (Zagorodnyuk, 1979). Late Virgilian of New Mexico (Krainer et al., 2017a). Asselian-Artinskian of the northwestern margin of the Paleotethys (Montenegro, Turkey, Carnic Alps, Italy, Croatia, Serbia and New Mexico). In the Carnic Alps: Forni Avoltri; Zweikofel, Zottachkopf, Trogkofel, Treßdorfer Kalk, Goggau Kalk (Flügel, 1968, 1979; Flügel and Flügel-Kahler, 1980; Vachard and Krainer, 2001b, sample ZKO10); represents a fertile stage of a dasyclad alga (Flügel, 2004). This study: Zweikofel Fm (samples GB36_4; GB60_2_2; GB61_4; GB72_1b; GB119_3; ZK94_7_4; ZK99a_10; ZK99c_9; ZK99c_13); Zottachkopf Fm (samples Z5_2; Z5_3; Z5B_3; Z7_2; Z7_3; Z9_1b; ZT1_5); and Trogkofel Fm (sample TK5_A).

Family DASYCLADACEAE Kützing, 1843

Tribe MIZZIEAE Vachard, Vandelli and Moix, 2013 Subtribe MIZZIINAE Bassoullet, Bernier, Deloffre, Génot, Jaffrezo and Vachard, 1979 Genus MIZZIA Schubert, 1907

Type species. Mizzia velebitana Schubert, 1908. Description. Thallus moniliform, euspondyl. Laterals vesiculifer more or less wide. Broad internal cavity. Outer surface with perforate cortex and partly prominences.

Remarks. The genus Mizzia was remarkably described and interpreted by Pia (1920) and Kochansky-Devidé and Gusić (1971). However, Chuvashov (2001) separated the three main species $M$. velebitana, $M$. yabei and $M$. cornuta into three different monospecific genera: Mizzia, Yabeites Chuvashov, 2001, and Cornutella Chuvashov, 2001. This proposal is not followed here, because it is inconsistent with our microfacies observations and the general difficulty in order to attribute 
numerous specimens to the different species, $M$. velebitana, $M$. yabei or $M$. cornuta. These three latter species are therefore considered here as three species of the same genus.

As indicated by Vachard et al. (2005, 2013), the name "Mizzia Schubert, 1909 [or 1907] (...) emend. Rezak, 1959" adopted by Praturlon (1963); Emberger (1976); and Granier and Grgasović (2000), is inappropriate because the unique species described by Rezak (1959), Mizzia brankampi Rezak, 1959, is probably an Eogoniolina similar to E. johnsoni Endo, 1953b; i.e., a representative of another genus. Other misinterpreted Eogoniolina include Mizzia yabei of the authors and Permoplexella Elliott, 1968a. Furthermore, it is yet difficult to determinate the exact number of species of Mizzia, and, as a consequence, the "genera" of Chuvashov (2001): Yabeites and Cornutella, as well as many mizziacean genera created in the studies of Endo, are probably unfounded. Similarly, the limit with Gyroporella and its numerous taphotaxa is difficult to be established. As we have never observed relationships between Coniporelleae and Mizzia, due to the absence of Triassic transitional taxa, we consider the mizziean forms as a distinct tribe.

Surprisingly, because these taxa have nothing in common, some Pseudovermiporella were interpreted as Mizzia velebetiana (sic) (e.g., Angiolini et al., 2010, figure 4.33).

Occurrence. Early-Late Permian; cosmopolitan; but the precise FAD (first appearance datum) and LAD (last appearance datum) are poorly known; the LAD is apparently Wuchiapingian (Zhao et al., 1981; Vachard et al., 2005; Vachard and Isozaki, unpublished data); even if Changhsingian Mizzia have been mentioned by Flügel and Reinhardt (1989), Sha et al. (1992) and Kolodka et al. (2012), all these latter seem to be misinterpreted Eogoniolina.

Mizzia velebitana Schubert, 1908

Figure 22.9-11, Figure 23.7, 23.9-12, 23.14?, Figure 25.3, 25.4, 25.6, 25.9 (top), 25.11-13, 25.14 ?

* 1908 Mizzia velebitana Schubert, p. 382, pl. 16, figs. 8-12.

1920 Mizzia velebitana; Pia, p. 19-23, text-fig. 4 p. 21, pl. 1, figs. 12-23.

1937 Mizzia velebitana; Pia, p. 822-828, text-figs. 1, 2, pl. 9, fig. 3 .

1942 Mizzia velebitana; Johnson, p. 203-205, textfig. 2 p. 204, pl. 2, figs. 1-4, pl. 3, figs. 1-4.

?p1951 Mizzia velebitana; Johnson, pl. 7, figs. 1-3 (non pl. 7, fig. 4 = Eogoniolina).
1960 Mizzia velebitana; Kochansky-Devidé and Herak, p. 81, pl. 5, figs. 1-6, 9-12.

1963 Mizzia velebitana; H. Flügel, p. 87, pl. 1, fig. 3 (with seven references in synonymy).

1963 Mizzia velebitana; Maslov et al., text-fig. 26.

non 1963 Mizzia velebitana; Praturlon, p. 130-131, pl. 5, figs. 1-7 (with six references in synonymy; for a taxon which belongs, in reality, to Eogoniolina).

1965 Mizzia velebitana; Herak, p. 214 (no illustration).

1968 Mizzia velebitana; Flügel, p. 46, 49, 56, 57 (no illustration).

?1970 Mizzia velebitana; Pantić, pl. 2, figs. 1-3.

1976 Mizzia velebitana; Emberger, p. 59-61 (no illustration) (with 107 references).

?p.1978 Mizzia velebitana; Zaninetti et al., pl. 84, figs. 1?, 3?, 9? (non fig. 2 = Salopekiella sp.; nec figs. 4-6, 11-14 = Mizzia yabei; nec fig. $7=$ Gyroporella? sp.).

v1980 Mizzia velebitana; Vachard, p. 360-362, pl. 4, figs. 4-6, pl. 23, fig. 12, pl. 24, fig. 1 (with 27 references).

?1981 Gyroporella nipponica Endo and Huzimoto; Bérczi-Makk and Kochansky-Devidé, pl. 3, fig. 7.

?1981 Mizzia velebitana; Mu, p. 45, pl. 4, fig. 10, 11 (another species or genus?).

1979 Mizzia velebitana; Flügel, p. 572 (no illustration).

1982 Mizzia velebitana; Mu, p. 228, pl. 8, figs. 3-5.

v1985 Mizzia velebitana; Vachard, p. 272, pl. 1, figs. 3, 10, pl. 3, figs. 3, 4 .

?1986a Mizzia velebitana; Nguyen Duc Tien, pl. 9, figs. 3, 4 (perhaps M. yabei).

v1986 Mizzia velebitana; Fontaine et al., pl. 24, figs. $1-4$.

v1989 Mizzia cornuta Kochansky and Herak; Vachard in Fontaine and Gafoer, pl. 7, fig. 2, pl. 9, fig. 4.

1989 Mizzia velebitana; Köylüoğlu and Altıner, pl. 2, fig. 5.

v1989 Mizzia velebitana; Vachard in Fontaine and Gafoer, pl. 7, fig. 2, pl. 9, fig. 4.

1990 Mizzia velebitana; Flügel, pl. 1, figs. 1-3.

1991 Mizzia velebitana; Flügel et al., pl. 47, fig. 2.

v1992 Mizzia velebitana; Vachard et al., pl. 3, fig. 3. v1992 Mizzia velebitana; Okla, pl. 45, figs 7-10.

non 1992 Mizzia velebitana; Sha et al., pl. 1, fig. 2 (= M. yabei).

2000 Mizzia velebitana; Granier and Grgasović, p. 102-107 (no illustration, with 134 references).

2004 Mizzia velebitana; Flügel, pl. 59, fig. 4. 

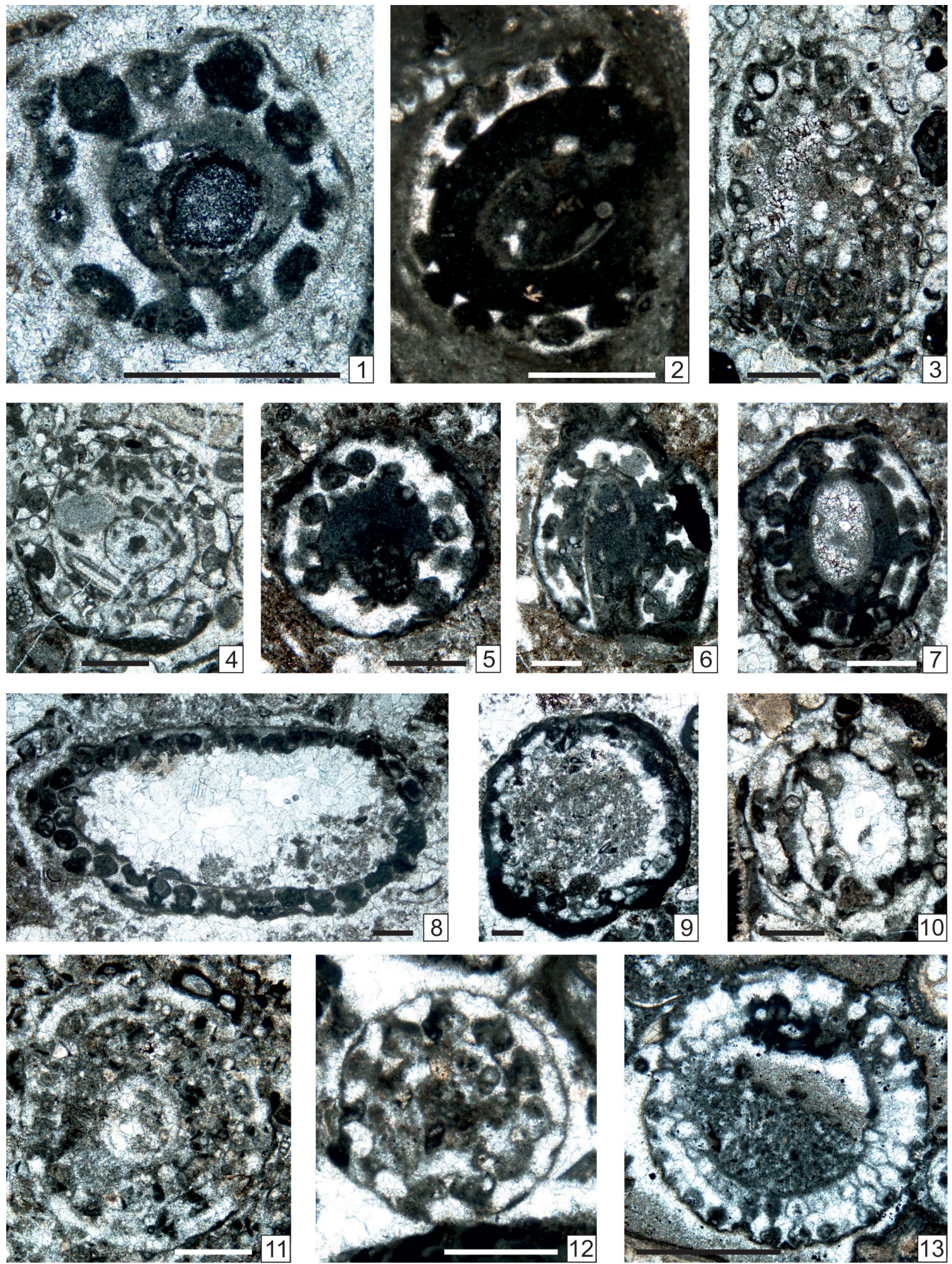

FIGURE 25. 1-12. Pseudoepimastopora carnica (Flügel, 1966) emend. herein, n. comb. 1. Transverse section. Sample GB36_4. 2. Oblique transverse section. Sample GB60_2_2. 3. Oblique section. Sample GB61_4. 4. Transverse section. Sample GB72_1b. 5. Transverse section. Sample Z5_2. 6. Oblique section. Sample Z5_3. 7. Transverse section. Sample Z7_2. 8. Longitudinal section. Sample Z7_3. 9. Transverse section. Sample Z9_1b. 10. Transverse section. Sample ZK99c_13. 11. Transverse section. Sample ZK94_7_4. 12. Transverse section. Sample ZK99a_10. 13. Globuliferoporella? sp. Transverse section. Sample Z19_3. Scale bars: $0.5 \mu \mathrm{m}$. 
p2004 Mizzia wackestone; Flügel, pl. 60, fig. 6 (non pl. 59, fig. 5 = Gyroporella sp.).

non 2005 Mizzia velebitana; Hughes, pl. 1, figs. 21-23 (= M. yabei), pl. 2, fig. 1 (= Macroporella? or Gyroporella?).

v2006 Mizzia velebitana; Insalaco et al., pl. 1, fig. 4.

p2009 ? Mizzia sp.; Bucur et al., figs. 8.4, 8.5 (non fig. $8.6=$ Gyroporella).

2010 Mizzia velebetiana (sic); Angiolini et al., fig. 4.33.

v2011 Mizzia velebitana; Vachard and Moix, p. 152, pl. 2, fig. 15.

v2012 Mizzia velebitana; Kolodka et al., p. 138, 139 (no illustration).

v2017 Mizzia velebitana; Granier et al., fig. 3A.

Description. Large species with subspherical segments and laterals relatively large. The perforate cortex is well visible in this species (Vachard, 1985, plate 3 , figure 10). Outer diameter $=800-1,700$ $\mu \mathrm{m}$; inner diameter $=500-900 \mu \mathrm{m}$; pore diameter $=$ 100-200 $\mu \mathrm{m}$; interpores $=20-40 \mu \mathrm{m}$.

Occurrence. Permian. Japan, Italy (Sicily, ?Dolomites), Slovenia, Croatia, Montenegro, Hungary, Carnic Alps, Greece, Tunisia, Turkey (Hazro, Lycian nappes), Iran (Alborz, Zagros), Saudi Arabia, Afghanistan, Pakistan, South China, Thailand, Malaysia, Sumatra, Philippines, Japan, Guatemala and southeastern USA. In the Carnic Alps: Schulterkofel and Zweikofel formations (Flügel, 1968, 1979). This study: Zweikofel Fm (samples GB123_1; GB123_1_6; GB67_10; GB67_11; GB72_3; GB109_2; GB129_3; GB129_6; GB146_2; ZK203_2); and Zottachkopf Fm (samples TKS 10_2; TKS 13_5).

Mizzia yabei (Karpinsky, 1909) emend. Pia, 1920

Figure 22.12?, 22.13?, Figure 23.4, 23.15-17,

Figure 25.1, 25.2, 25.5, 25.7, 25.8, 25.9 (bottom), 25.10

*1909 Stolleyella yabei Karpinsky, p. 268, 269.

1920 Mizzia yabei; Pia, p. 23-24, text-fig. 5 p. 24, pl. 1, figs. 4-6.

1937 Mizzia yabei; Pia, p. 828 (no illustration).

1942 Mizzia yabei; Johnson, p. 207-208, text-fig. 3 p. 204, pl. 3, figs. 4-6, pl. 7, fig. 2.

1962 Mizzia? cf. yabei; Kochansky-Devidé and Milanović, p. 217-218, pl. 7, figs. 1-3.

?1963 Mizzia velebitana; Praturlon, p. 130-131, pl. 5, figs. 1-7.

1965 Mizzia yabei; Herak, p. 214 (no illustration).

1968 Mizzia cornuta Kochansky and Herak; Flügel, p. 57 (no illustration).

1970a Mizzia yabei; Kochansky-Devidé, p. 213, 240, pl. 23, figs. 5,6 .

1973 Mizzia sp.; Bozorgnia, pl. 48, fig. 12.
1976 Mizzia yabei; Emberger, p. 61-62 (no illustration) (with 29 references).

p.1978 Mizzia velebitana Schubert; Zaninetti et al., pl. 84, figs. 4-6, 11-14 (non fig. 2 = Salopekiella sp., nec fig. 7 = Gyroporella? sp.).

1979 Mizzia yabei; Flügel, p. 572 (no illustration).

1981 Mizzia yabei; Ramovš and Kochansky-Devidé, p. 97, pl. 1, fig. 1.

1982 Pseudogyroporella mizziaformis Endo; Mu, p. 230, pl. 7, figs. 1-3.

non v1985 Mizzia yabei; Vachard, p. 272, pl. 1, fig. 1 (= Eogoniolina).

?1985 Pseudogyroporella mizziaformis; Mu, pl. 14, fig. 4.

?1985 Gyroporella mizziaformis; Mu, pl. 15, fig. 7.

?1986a Mizzia velebitana; Nguyen Duc Tien, pl. 9, figs. 3, 4.

1990 Mizzia yabei; Flügel, pl. 4, fig. 6.

1991 Mizzia cornuta; Flügel et al., pl. 47, fig. 1.

?1991 Atractyliopsis; Riding and Guo, fig. 3.

v. 1992 Mizzia yabei; Vachard et al., pl. 3, fig. 5.

1992 Mizzia velebitana; Sha et al., pl. 1, fig. 2.

v. 1993a Mizzia yabei; Vachard et al., pl. 1, fig. 3, pl. 2, fig. 6.

1997 Mizzia yabei; Wendt, p. 361, 362, 363, textfig. 2 p. 362 , text-fig. 3 p. 363 , text-fig. 4 p. 364, text-fig. 5 p. 365 , text-fig. 6 p. 366.

2000 Mizzia yabei (Karpinsky) Pia; Granier and Grgasović, p. 107-109 (no illustration, with 47 references in synonymy).

2000 Mizzia; Kiessling and Flügel, pl. 10, fig. 2.

2004 Mizzia; Flügel, pl. 101 (full page).

2005 Mizzia velebitana; Hughes, pl. 1, figs. 21-23.

2008 Mizzia velebitana; Lai et al., text-fig. 3 p. 82

v2011 Mizzia yabei; Vachard and Moix, p. 152 (no illustration).

v2012 Mizzia yabei; Kolodka et al., p. 138, 139, fig. 81.

v2013 Mizzia yabei; Parvizi et al., p. 161, fig. 7a-7c, 7d?, 7e, 7g?

v2016 Mizzia sp.; Angiolini et al., fig. 11.B, 11C.

Description. Segments ovoid; laterals relatively narrow. Outer diameter $=1,300-6,000 \mu \mathrm{m}$; wall thickness $=160-240 \mu \mathrm{m}$; pore diameter $=80-160$ $\mu \mathrm{m}$.

Remarks. Mizzia yabei is characterized by clubshaped articles and the drum-stick form of the laterals. Mizzia velebitana differs by the wider spherical articles and $M$. cornuta Kochansky and Herak, 1960 , by horny protuberances at the extremities of the laterals.

Occurrence. Permian. Japan, ?ttaly (?Dolomites, ?Sicily), Slovenia, Croatia, Montenegro, Hungary, Carnic Alps, Greece, Tunisia, Turkey (Hazro, 
Lycian nappes), Iran (Alborz, Zagros), Saudi Arabia, Afghanistan, Darvas, Pakistan, South China, Thailand, Malaysia, Philippines, Guatemala, southwestern USA. In the Carnic Alps: Seikofel, Sexten, Dolomites, Italy (Flügel, 2004); Karawanken Mountains (Ramovš and Kochansky-Devidé, 1981); this study: Zweikofel Fm (samples GB43_5; GB66_11; GB67_10; GB71_1_1; GB71_1_2?; GB72_6; GB127_19; GB146_2; GB163_5; GB163_10; GB174_4; GB175_3; GB175_11; ZK94_5_4; ZK96_11; ZK199_8; ZK200_5; ZK200_6; ZK200_7; ZK202_6; ZK203_2; ZK204_A; ZK207_7); Zottachkopf Fm (samples TKS12_2; TKS12_3a; TKS12_3b; TKS12_4; TKS13_5; Z13B_4; Z14_1_2); and Trogkofel Fm (samples GBT_1_4; TK36_3).

Mizzia cornuta Kochansky and Herak, 1960

Figure 22.7-8, Figure 23.3, 23.5-6, 23.8, 23.13,

$$
23.18
$$

*1960 Mizzia cornuta Kochansky and Herak, p. 8386, text-fig 4 p. 84, pl. 7, figs. 1-14.

1962 Mizzia cornuta; Kochansky-Devidé and Milanović, p. 217, pl. 6, figs. 4-5.

non.1964 Mizzia cf. cornuta; Kochansky-Devidé, p. 513, 516 (no illustration; but probable tectonic mélange).

1965 Mizzia cornuta; Herak, p. 210, 214 (no illustration).

1968 Mizzia cornuta; Flügel, p. 46, 55, 56, 57 (no illustration).

1970a Mizzia cornuta; Kochansky-Devidé, p. 213, 240, pl. 23, figs. 1-4.

?1970 Mizzia cornuta; Pantić, pl. 1, figs. 2, 3 (or abraded M. yabei?).

1979 Mizzia cornuta; Emberger, p. 57 (no illustration) (with 18 references).

1979 Mizzia cornuta; Flügel, p. 572 (no illustration).

1980 Mizzia cornuta; Flügel and Flügel-Kahler, p. 137-138, pl. 2, figs. 9, 10 (with 11 references).

1982 Mizzia cornuta; Mu, p. 227-228, pl. 8, fig. 6.

v1989 Mizzia cornuta; Vachard in Fontaine and Gafoer, pl. 7, fig. 1.

?1991 Mizzia cornuta; Flügel et al., pl. 47, fig. 1 (most probably M. yabei).

v. 1992 Mizzia cornuta; Vachard et al., pl. 3, fig. 8.

v1993a Mizzia cornuta; Vachard et al., pl. 1, fig. 4, pl. 7, fig. 14.

1997 Mizzia cornuta; Sokač et al., p. 145 (no illustration).

2000 Mizzia cornuta; Granier and Grgasović, p. 99-101, figs. 16, 17 (with 27 references). v.2001a Mizzia cornuta; Vachard and Krainer, p. 151 (no illustration).

2001 Cornutella cornuta; Chuvashov, p. 102, fig. 2g.

v.2003a Mizzia cf. cornuta; Krainer et al., table 1 p. 18, p. 19, pl. 7, fig. 10.

2007 Mizzia cornuta; Sremać, pl. 2, fig. 3.

2007 Mizzia cornuta; Grgasović and Sokač, pl. 2, fig. 4.

v2011 Mizzia cornuta; Vachard and Moix, p. 152 (no illustration).

v2013 Mizzia cornuta; Vachard et al., p. 530, fig. 7.1.

v2016 Mizzia cf. cornuta; Angiolini et al., fig. 12B.

v.2017a Mizzia cf. cornuta; Krainer et al., p. 20 (no illustration).

Description. Thallus length $=1,000-1,100 \mu \mathrm{m}$; thallus outer diameter $=790-1,500 \mu \mathrm{m}$; thallus inner diameter $=370-600 \mu \mathrm{m}$; wall thickness $=$ 250-400 $\mu \mathrm{m}$; diameter of laterals (= pores) $=90$ $150 \mu \mathrm{m}$; interpore $=45-55 \mu \mathrm{m}$ ). As indicated in its diagnosis, $M$. cornuta is smaller than $M$. velebitana, and classically the laterals are prolonged by "limy horns".

Occurrence. The species is distributed in the entire Permian, from Asselian to Changhsingian. Early Permian of western Tethys. Late Kungurian of southern Crete (Vachard et al., 2013). ?Early Guadalupian of western Sicily (Flügel et al., 1991). Acme in the Middle Permian of Croatia, Slovenia, Montenegro, Serbia, Chios Island, Carnic Alps, Tunisia, Turkey (western Taurus), Urals, Iran (Alborz), Tibet, Thailand, Sumatra, New Mexico (USA). Late Permian of Greece (Vachard et al., 1993a). Late Midian-Changhsingian of southern Turkey (Hazro), Zagros, Fars and Abu Dhabi. In the Carnic Alps: Auernig Fm (Vachard and Krainer, 2001a); Schulterkofel Fm, Zweikofel Fm and Trogkofel Fm (Flügel, 1968, 1979). This study: Zweikofel Fm (samples GB40_6; GB 40_6a; GB43_5; GB66_11; GB70s_3; GB72_3; GB105_5; GB106_A; GB109_2; GB111_4; GB128_1; GB128_4; GB129_3; GB129_6; GB130_1; GB130_3; GB152_13; GB156_4?, GB156_9; GB163_5; GB163_16; GB165_8; GB171_11; GB173_2; GB173_18; GB174_1; ZK94_54?); Z̄ottachkopf Fm (samples Z13B_4; Z14_1); and Trogkofel Fm (sample GBT1_1).

Family DIPLOPORACEAE Pia, 1920 nom. translat. Shuysky, 1987 and/or Deloffre, 1987

Tribe LULIPOREAE Shuyshy in Chuvashov, Luchinina, Shuysky, Shaikin, Berchenko, Ishchenko, Saltovskaya and Shirshova, 1987, 
emend. Vachard, Hauser, Martini, Zaninetti, Matter and Peters, 2001a

Remarks. The Luliporeae are metaspondyl Dasycladales with one to several verticils of simple laterals L1 (rarely L2 and L3) with an individualized calcification. The Diploporeae are metaspondyl dasyclads, which lack vestibules (although some confusions are possible when the L1 are very short), contrary to the Velebitelleae, which are metaspondyl dasyclads with vestibules. The Clypeinae have simpler verticils (Vachard et al., 2001a).

Occurrence. Early Devonian (Emsian)-Middle Permian (Capitanian); Tethyan and Uralian shelfs as well as the Americas from Guatemala to New Mexico (USA).

\section{Genus CONNEXIA Kochansky-Devidé, 1970b}

Type species. Connexia fragilis Kochansky-Devidé, $1970 \mathrm{~b}$

Description. Thallus with distant verticils. Cylindrical central cavity. Each verticil displays a first generation of acrophore, cylindrical laterals, followed by a tuft of secondary laterals, metaspondyl, elongate piriform. The axial cell and each lateral possesses its proper calcification.

Occurrence. Only Asselian according to Chuvashov et al. (1993), although given as present in the early Moscovian (Kochansky-Devidé, 1970b). Most probably Kasimovian (Vachard and Moix, 2011) to Kungurian (Angiolini et al., 2016): Tunisia, Tibet, Sumatra, Carnic Alps, Croatia, Guatemala (Vachard et al., 1997).

Connexia slovenica Kochansky-Devidé, 1979 Figure 26.1-4, Figure 27.9

1970a Teutloporella n. sp.; Kochansky-Devidé, p. 214, 416, 241-242, pl. 22, figs. 5, 6 .

1972 Likanella? cf. L. spinosa Milanović; Homann, p. 210, pl. 6, fig. 44.

?1979 Salopekiella sp.; Flügel, p. 572 (no illustration).

*1979 Connexia slovenica Kochansky-Devidé, p. $6-7$, pl. 1, figs. 16 , pl. 2, figs. 1-3 (with five references in synonymy).

1980 Connexia carniapulchra Flügel and FlügelKahler; Flügel, pl. 8, fig. 4 (nom. nud.)

1980 Connexia carniapulchra Flügel and FlügelKahler, p. 128, 130-131, pl. 2, fig. 9, pl. 3, figs. $1-8$.

1982 Dasycladaceae gen. et sp. indet.; Mu, p. 231, pl. 6, figs. 11-13.

v1989 Connexia slovenica; Vachard in Fontaine and Gafoer, pl. 7, figs. 3-6, pl. 9, figs. 2, 3.

1991 Connexia sp.; Flügel et al., pl. 47, fig. 4.
2000 Connexia slovenica; Granier and Grgasović, p. 30-31 (no illustration, with 13 references).

v2001a Connexia slovenica; Vachard and Krainer, p. 151 , pl. 5 , figs. 2,3 .

v2001b Connexia slovenica; Vachard and Krainer, p. 172, pl. 3, figs. 9, 10.

v?2001a Likanella? sp.; Vachard et al., fig. 14.5.

2004 Connexia; Flügel, pl. 101 (full page).

v2011 Connexia sp.; Vachard and Moix, p. 152, 154 , pl. 2, fig. 17 , pl. 3 , figs. $18,26 ?$

v2015 Connexia slovenica; Ghazzay-Souli et al., p. 253 (no illustration).

v.2017 Connexia cf. fragilis Kochansky-Devidé; Lucas et al., p. 15 (no illustration).

v.2017a Connexia cf. fragilis; Krainer et al., p. 20, 40, pl. 30, fig. 2, pl. 35, fig. 4.

v.2017a Connexia ex gr. fragilis; Krainer et al., p. 20, 40, pl. 43, fig. 16.

Description. Outer diameter $=3,100 \mu \mathrm{m}$; inner diameter $=1,700 \mu \mathrm{m}$; length of laterals $=1,250-$ $1,700 \mu \mathrm{m}$; diameter of laterals $=150-280 \mu \mathrm{m}$; interpores $=50-100 \mu \mathrm{m}$; number of tufts per verticil: 10. C. slovenica differs only from $C$. fragilis by more numerous tufts in the verticils (10-11 versus 5-6).

Occurrence. Late Pennsylvanian (Vachard and Krainer, 2001a; Vachard and Moix, 2011)-Early Permian of the Carnic Alps, Slovenia and Tibet; Asselian of Tunisia and New Mexico; Artinkian of Guatemala; Sakmarian of Sumatra (see compilation in Granier and Grgasović, 2000); ?Kubergandian of Oman (Vachard et al., 2001a); ?Capitanian of western Sicily (Flügel et al., 1991) and Texas (Flügel, 2004, plate 145, figure 4). In the Carnic Alps: Pizzul Fm (Vachard and Krainer, 2001a); Zottachkopf (Homann, 1972); Zweikofel Fm (Flügel, 1979; Vachard and Krainer, 2001b; sample ZKO32); Trogkofelkalk of Slovenia (KochanskyDevidé, 1979); Forni Avoltri (Flügel, 1980; Flügel and Flügel-Kahler, 1980); Zweikofel; Trogkofel; Traviser Brekzie (Flügel, 2004). In this study, very rarely found in the Zweikofel Fm (sample GB40_2); Zottachkopf Fm (samples GBT3_2; Z9B_7; ZK199_4?; ZT1_5); and Trogkofel Fm (samples GBT3_4?; GBT4_2; GBT4_2).

\section{Genus Salopekiella Milanović, 1965}

Type species. Salopekiella velebitana Milanović, 1965.

Description. Thallus with pile of conical segments. Cylindrical central cavity. Each segment bears a pair of verticils of primary laterals, euspondyl, oblique and phloiophore.

Occurrence. Middle Permian of Croatia, Afghanistan, Thailand, Turkey and Tunisia (compiled 
herein). Perhaps present in the Artinskian of the Carnic Alps (this study).

\section{Salopekiella? sp. \\ Figure 27.5}

Description. A unique section shows prominent verticils and a cylindrical axial cell similar to those of Salopekiella; however, this latter genus appears in the Middle Permian. Length $=2,100 \mu \mathrm{m}$ (with four verticils); outer diameter $=950 \mu \mathrm{m}$, inner diameter $=610 \mu \mathrm{m}$, wall thickness $=180 \mu \mathrm{m}$; width of laterals $=150 \mu \mathrm{m}$.

Occurrence. Very rare and questionable in the basal Trogkofel Fm (sample TM5_2).

\section{"Algen Sporen"}

Figure 21.7, 21.9, 21.11, Figure 22.11-2, Figure 23.16, Figure 24.3, Figure 25.3, 25.4, 25.10, Figure 27.13-15, Figure 28.8-9, Figure 30.11

Remarks. In our material, the Algen Sporen of Flügel (see e.g., Flügel, 1979, plate 1, figure 5; 1980 , plate 5 , figures $1,4,5$, plate 2 , figure 10) are relatively common. They have also been designated as Penella pongaensis Mamet and Villa, 2004 (p. 176, figure 15b-15k). Cózar et al. (2018) discuss a green algal origin of these "algal spores" in late Viséan to early Bashkirian shallow-marine limestones of the Cantabrian Mountains (Spain). In our opinion, both taxa are most probably abraded desmes of Geodiidae sponges (rhaxes, rhaxasters) or other neosparitized, siliceous sponge spicules such as the selenasters of Placospongia (Maclntyre, 1977; Lukowiak et al., 2018).

Occurrence. Late Pennsylvanian to Holocene, probably cosmopolitan.

Class ALGOSPONGIA G. Termier, Termier and Vachard, 1977, emend. Vachard and Cózar, 2010

Remarks. Two groups of incertae sedis algae were encompassed in the incertae sedis class Algospongia by G. Termier et al. (1977): Moravamminales and Aoujgaliales. They were hardly discussed (Mamet, 1991), and often separated in two groups by the authors, the former being considered as green algae and the latter as red algae. We use here the revision of Vachard and Cózar (2010) for the description of the two groups and we admit the reality of the class Algospongia.

Occurrence. Ordovician-Permian (rare but unquestionable taxa in the Jurassic-Cretaceous). Ordovician with Wetheredellaceae and some Moravammina? Late Silurian/ Early Devonian-Late Permian for the other families. Rare Lazarus effects in the Mesozoic (Kamaena khuraisensis Adams and Al-Zahrani, 2000; Koskinobullina socialis Cherchi and Schroeder, 1979; and Hensonella dinarica Elliott, 1960).

Order MORAVAMMINALES Pokorny, 1951, emend. Vachard in Termier, Termier and Vachard, 1975

Family CLARACRUSTACEAE Vachard in Vachard, Hauser, Martini, Zaninetti, Matter and Peters, 2001a, emend. Vachard and Cózar, 2010 Genus CLARACRUSTA Vachard in Vachard and Montenat, 1981

Type species. Girvanella catenoides Homann, 1972.

Synonyms. Girvanella (part.); Berestovia Berchenko, 1982 (non sensu Mamet and Villa, 2004).

Description. Thallus encrusting, formed by a superposition of continuous rows of highly calcified hemispherical to ellipsoidal cells, flattened at the base. Wall hyaline, yellowish.

Remarks. Claracrusta associated with Girvanella and/or other cyanobacterial crusts constitute the assemblages of "Ottonosia"-type, very numerous during the Permian, but yet present since the Brigantian (Vachard and Cózar, 2010). The Ottonosia biopisoids, composed of cyanobacteria and Claracrusta, in the Late Pennsylvanian and Early Permian (e.g., Homann, 1972; Vachard, 1980) are probably paleoecologically comparable with the modern macroids with Acervulina (i.e., biopisoids growing in relatively deep, 60-70 m deep fore-reef, or cryptic habits) (Hottinger, 1983; Perrin, 1992).

Occurrence. Late Viséan to Late Permian, cosmopolitan (Vachard and Cózar, 2010 with references therein).

Claracrusta catenoides (Homann, 1972) emend. Vachard in Vachard and Montenat, 1981 Figure 20.1, Figure 26.5-8

p1919 Ottonosia laminata Twenhofel, p. 348-350, text-fig. 3.

p.1963 Ottonosia laminata; Johnson, p. 134-135, pl. 80 , fig. 1 (only; figs. $2-5$ are uninterpretable outer view of oncoids)

p. 1967 Ottonosia laminata; Fournié, pl. 1, fig. 1 (only; figs. 2-4 are uninterpretable outer view of oncoids).

*1972 Girvanella catenoides Homann, p. 239-241, pl. 8 , figs. 59 a-c.

.1972 "Stacheoides" spissa Petryk and Mamet, p. 28-29, pl. 8, figs. 1-4.

1974 Donezella intertexta Chuvashov, p. 33-34, pl. 20, figs. 5-9.

1979 Donezella intertexta Zagorodnyuk, p. 12, pl. 3 , fig. 6 (sic; in reality, fig. 5). 

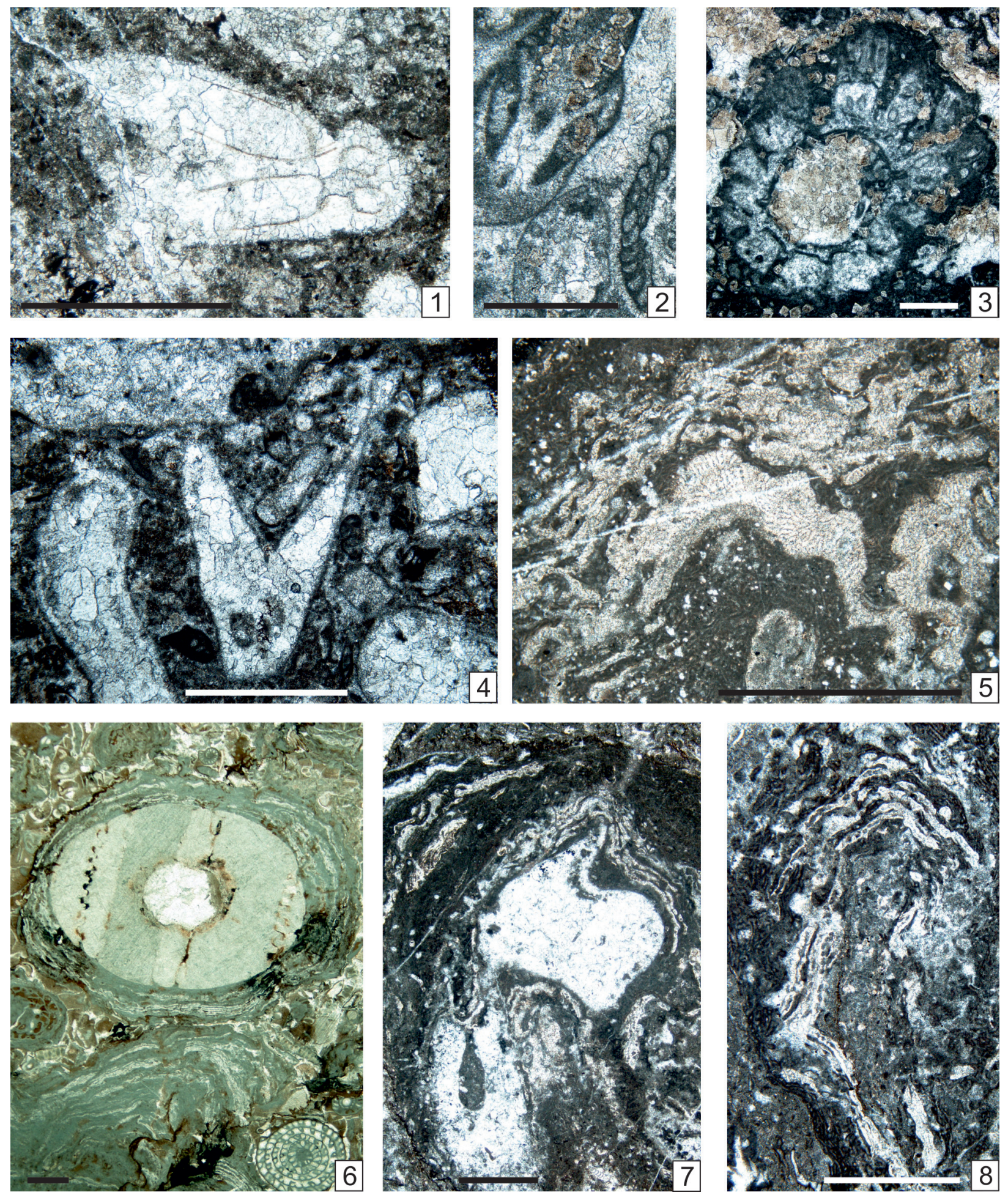

FIGURE 26. 1, 2, 4. Connexia slovenica Kochansky-Devidé, 1979. 1. Oblique section of two laterals. Sample GB40_2. 2. Fragment of longitudinal section. Sample GBT4_2. 4. Two laterals. Sample Z9B_7. 3. Connexia? sp. Sample GBT3_2. 5-8. Claracrusta catenoides (Homann, 1972) emend. Vachard in Vachard and Montenat, 1981. Longitudina section with a tangential section in Figure 26.5. 5. Sample GB36_5. 6. Sample TNA18_1_2. 7. Sample TKW6B_3. 8. Sample TKW4_1. Scale bars: $1 \mu \mathrm{m}$. 

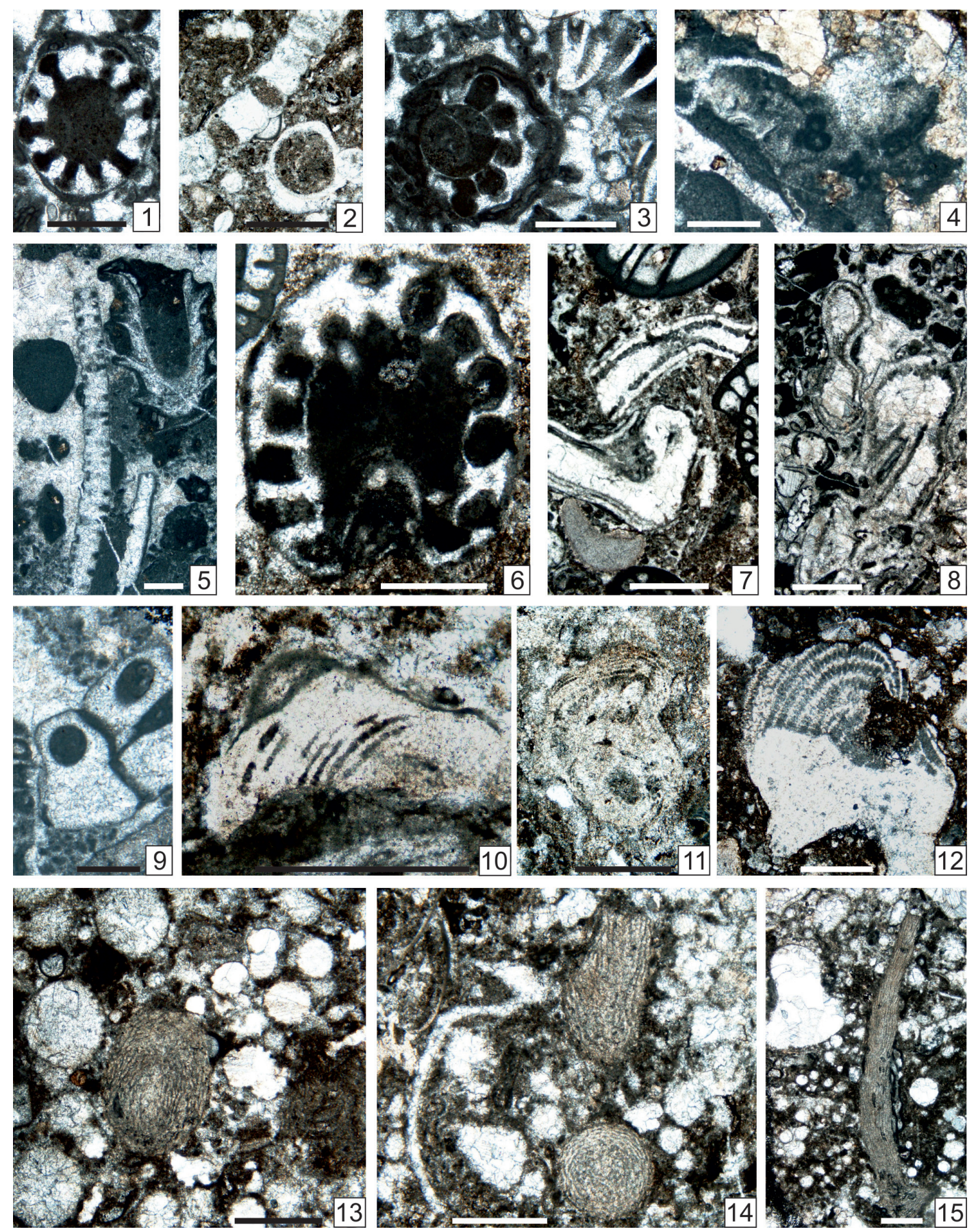

FIGURE 27. 1. Gyroporella sp. Transverse section. Sample ZT1_6. 2. Epimastopora likana Kochansky and Herak, 1960 emend. herein. Longitudinal section. Sample GB156_8. 3, 6. Pseudoepimastopora carnica n. comb., emend. herein. 3. Transverse section with Connexia slovenica Kochansky-Devidé, 1979 (top, right) in axial section. Sample ZT1_5. 6. Oblique transverse section. Sample Z5B_3. 4. Renalcis cf. granosus Vologdin, 1932. A colony associated with Tubiphytes carinthiacus (Flügel). Sample GBT11_2. 5. Epimastopora cf. izawaikensis Endo, 1953a. Longitudinal section (left) with Salopekiella? sp. (top right) in axial section. Sample TM5 2. 7, 8. Neoanchicodium catenoides Endo in Endo and Kanuma, 1954. Numerous sections. 7. Sample Z9B_3. 8. Sample TKS12_1_2. 9. Connexia slovenica Kochansky-Devidé, 1979. Small fragment with two laterals, in transverse and oblique sections. Sample TK32. 10-12. Efluegelia ex gr. johnsoni (Flügel, 1966). Three longitudinal sections more or less recrystallized. 10. Sample GB157_10. 11. Sample GB162_1. 12. Sample Z17B_1. 13-15. Ungdarella uralica Maslov, 1956. Several sections with "Algen Sporen". 13. Sample ZK198_9. 14. Sample ZK200_2. 15. Sample ZK200_9. Scale bars: Figure $27.8=1 \mu$ m, Figure $27.11=0.25 \mu \mathrm{m}$, all others $=0.5 \mu \mathrm{m}$. 
v1980 Claracrusta catenoides; Vachard, p. 392393, pl. 3, fig. 1 , pl. 7 , fig. 5 , pl. 25 , fig. 1 , pl. 26, figs. $1-3$.

1980 Girvanella catenoides; Flügel, pl. 9, figs. 2, 5. v1981 Claracrusta catenoides; Vachard in Vachard and Montenat, p. 57-58, pl. 1, fig. 1, pl. 8, figs. $8,10,12$, pl. 9 , fig. 1 , pl. 12, fig. 10 (with synonymy).

1982 Berestovia filaris Berchenko, p. 53, pl. 12, figs. 1-4.

1983 Berestovia filaris; Berchenko in Aizenverg et al., p. 128 , pl. 84 , fig. 2 , pl. 86 , figs. 5,6 , pl. 87, fig. 1.

p. 1983 Donezella delicata; Berchenko in Aizenverg et al., p. 126, pl. 86, figs. 2, 3 (non pl. 85, figs. $5-9$, true $D$. delicata).

v1984 Claracrusta catenoides; Fontaine and Vachard, p. 51 (no illustration).

1985 Rothpletzella? sp., Mu, pl. 12, figs. 4-6.

1986 Claracrusta catenoides; Poncet, p. 192, pl. 3, fig. 5 .

1988 Claracrusta catenoides; Ivanova, p. 7 (no illustration).

1989 Claracrusta sp.; Sebbar and Lys, pl. 1, fig. 6.

v1989 Claracrusta catenoides; Vachard in Fontaine and Gafoer, pl. 8, fig. 6.

1990 Claracrusta catenoides; Flügel, pl. 1, fig. 4.

1990 Claracrusta catenoides; Bogush et al., p. 8485 , tabl. 1 p. 9 , pl. 5, fig. 10 (with synonymy).

vp. 1992 no legend (encrusting the Coeloporella);

Vachard et al., pl. 3, fig. 11.

v1993b Claracrusta catenoides; Vachard et al., pl. 2, fig. 5.

1995 Claracrusta catenoides; Forke, p. 241, pl. 17, figs. $5,7$.

1996 Claracrusta catenoides; Mamet, pl. 2, figs. 814 , pl. 3 , figs. 6,7 .

1996 Claracrusta catenoides; Sebbar and Mamet, pl. 1 , figs. 4,5 .

v1996 Claracrusta catenoides; Proust et al., p. 346 (no illustration).

v1996 Claracrusta catenoides; Vachard and Maslo, p. 369-370, text-fig. 2 p. $360-365$, pl. 1, figs. 1, 2 (with synonymy).

1997 Berestovia filaris Berchenko; Harris et al., fig. 9.12.

v.1997 Claracrusta catenoides; Fontaine et al., p. 7 (no illustration).

1999 Berestovia? ou Iberiaella?; Sebbar and Mamet, text-fig. 3.100.

1999 Claracrusta catenoides; Sebbar and Mamet, text-fig. 3.99.

$2000 \quad$ Claracrusta sp.; Sebbar, pl. 1, fig. 10.

2000 Claracrusta catenoides; Mamet and Stemmerik, fig. $9 \mathrm{E}, 9 \mathrm{~F}$. v2001a Claracrusta ex gr. catenoides; Vachard and Krainer, pl. 5, fig. 8.

2002 Claracrusta catenoides; Mamet, p. 502, pl. 7, fig. 3 (with synonymy).

2003 Claracrusta catenoides; Khodjanyazova and Mamet, pl. 5, figs. 8, 9.

2003 Claracrusta catenoides; Cózar et al., pl. 5, fig. 1.

v2003a Claracrusta catenoides; Krainer et al., table 1 p. 18 , p. 19, pl. 3, fig. 32.

2003 Red algae-like organisms (R); Igawa, p. 74, pl. 12, fig. 10, pl. 13, fig. 3?, pl. 14, fig. 8.

? 2004 Claracrusta spp. (mostly C. catenoides (Homman) (sic) emend. Vachard); Cózar, p. 373, text-fig. 3 p. 371 (no illustration).

2004 Claracrusta catenoides; Cózar and Rodríguez, fig. 9.17.

2004 Claracrusta catenoides; Cózar and Somerville, text-fig. 5 p. 46 , text-fig. 8 p. 48 , text-fig. 9 p. 49 , fig. $13.6,10$, fig. 14.25 .

2004 Claracrusta catenoides (= Berestovia filaris Berchenko, 1982; see Mamet, 2002); Brenckle, pl. 6, fig. 10.

2004 Berestovia filaris Berchenko; see Mamet 2002 (sic); Mamet and Villa, p. 172, pl. 6, fig. $14 \mathrm{n}, 140$ (with four references in synonymy).

2004 Claracrusta catenoides (Homann); see Mamet 2002 (sic); Mamet and Villa, p. 172, pl. 6, fig. 10 (with 19 references in synonymy).

2005 Claracrusta catenoides; Mamet and Zhu, fig. 5I, 6D.

2005a Claracrusta catenoides; Cózar and Somerville, text-fig. 16 p. 25, fig. 14.6.

2005b Claracrusta catenoides; Cózar and Somerville, pl. 2, fig. 5 .

2006 Claracrusta based-oncoid; Kabanov et al., pl. 1, fig. 16.

2008 Claracrusta ex gr. catenoides; Pille, p. 77-78, pl. 25, figs. 9-15.

v2009 Claracrusta catenoides; Krainer et al., p. 13, 15, pl. 3, fig. 4.

v2010 Claracrusta catenoides; Vachard and Cózar, p.183, pl. 6, figs. $2-5$.

2010 Claracrusta catenoides; Mamet and Préat, p. 16 , pl. 4, figs. 1-4.

v2011 Claracrusta catenoides; Vachard and Moix, p. 152, 154, 156 (no illustration).

v2012 Claracrusta catenoides; Kolodka et al., fig. 8h.

v2013 Claracrusta catenoides; Moix et al., p. 411.

v.2015 Claracrusta; Krainer et al., figs. 19.2, 20.6, 20.7.

v2017 Claracrusta ex gr. catenoides; Lucas et al., p. 15 (no illustration). 
v2017a Claracrusta catenoides; Krainer et al., p. 20, 39 , pl. 19 , fig. 12 , pl. 27 , figs. 6,7 , pl. 34 , fig. 8 , pl. 37 , fig. 9.

v2017b Claracrusta sp.; Krainer et al., fig. 28A?, B, F?.

Description. See Vachard (1980, p. 393) and Pille (2008, p. 78). Diameter of cells $=30-50 \mu \mathrm{m}$; heigth of cells $=40-70 \mu \mathrm{m}$; wall thickness $=7-10 \mu \mathrm{m}$.

Occurrence. As for the genus. In the Carnic Alps: Orenburgian (Vachard and Krainer, 2001a); this study: Zottachkopf Fm (samples TKW 4_4; TKW 4_1; TKW6B_3; TNA16_2_4a; TNA18_1_2; TNA1_1_4; Z6B_3a; Z6B_3b); basal Trogkofel Fm (samples GB36_5; TM7_3).

\section{Order AOUJGALIALES Termier, Termier and Vachard, 1975, emend. Vachard and Cózar, 2010 \\ Family UNGDARELLACEAE Maslov, 1956b}

Description. Aoujgaliales arborescent, cylindrical, branched, and embracing growth of the chamber rows. In some of the specimens, there is an initial stage, attached, followed by an erect stage. The endoskeleton is composed of conical to paraboloid concentric laminae growing upward continuous rows of chambers, and perforated pillars, transverse, perpendicular to each lamina, acting as communications between the chambers. Wall calcitic, yellowish and hyaline.

Occurrence. Late Viséan (late Asbian) to latest Permian (Changhsingian). Cosmopolitan up to the Early Permian; after that, Paleotethyan and Neotethyan.

Genus UNGDARELLA Maslov (1950) 1956a

Type species. Ungdarella uralica Maslov (1950) $1956 a$.

Description. Thallus cylindrical and branched. In some of the specimens, there is an initial stage, attached, followed by an erected stage. The endoskeleton is composed by conical to paraboloid concentric laminae growing upward and perforated pillars perpendicular to each lamina. A medium perforation within the pillar acts as communication between the chamberlets ("cells" of the authors). Wall calcitic, yellowish, hyaline.

Remarks. For the year of description of this genus see Vachard and Cózar (2010; with references therein). Ungdarella is generally interpreted as a red alga, with a hypothallus and a perithallus (Mamet, 1991; Flügel, 2004, plate 108, figures 7, 8 ), but this explanation is irrelevant (Vachard and Cózar, 2010). The skeletal network of Ungdarella is generally sharply recrystallized, but when it is well preserved, it appears as perforated and partly filled with micrite and differs from the completely close cells of red algae always occupied by a precipated microsparite. Due to this strong and variable recrystallization, the four morphogenera created by Ivanova (1999) and Chuvashov and Anfimov (2007) are most probably several diagenetic stages of true Ungdarella (Vachard and Cózar, 2010). On the other hand, some systems of attachment, totally unknown among the red algae, have been illustrated (Vachard and Cózar, 2010; with references therein).

Occurrence. Late Asbian (late Viséan) to Changhsingian (latest Permian). The FAD is probably the best marker at the base of the late Asbian (upper part of MFZ 14 biozone = Cfm6, Cf6r2 or upper V3br: Vachard, 1988; Gallagher and Somerville, 1997; Gallagher, 1998; Cózar and Somerville, 2004; Poty et al., 2006; Hance et al., 2011). Common in the Tethyan and Uralian shelves up to the Early Permian; absent from Siberia (Ivanova and Bogush, 1992) and Japan (Mamet, 2002); rare in the North American Craton (where the most common ungdarellaceans belong to Komia Kordé, 1951; Krainer et al., 2017a, 2017b). During the Middle-Late Permian, Ungdarella is only Paleotethyan and Neotethyan.

Ungdarella uralica Maslov, 1956a, non 1956b, nec 1950

Figure 27.13-15, Figure 28.1-9

1950 Ungdarella uralica Maslov, p. 75-78, fig. 1.

*1956a Ungdarella uralica; Maslov, p. 73, pl. 21, textfigs. 18,19 , figs. 2,3 , pl. 23, figs. 1-4.

1956b Ungdarella uralica; Maslov, p. 151-152, fig. 1.

1963 Ungdarella uralica; Johnson, p. 6, pl. 1, figs. 1-3.

1963 Ungdarella uralica; Maslov et al., p. 29, textfigs. $17 a-17$ e, pl. 20, figs. $1,2$.

1966 Ungdarella uralica; Chanton, p. 407-408, text-fig. 1A, C, pl. 8, fig. 3.

1966 Ungdarella uralica; Flügel, p. 14-16, pl. 1, figs. $1,2$.

1968 Ungdarella uralica; Flügel, p. 55 (no illustration).

1970b Ungdarella uralica; Elliott, p. 448, pl. 83, fig. 6.

1972 Ungdarella uralica; Chanton-Güvenç, pl. 4, fig. 4.

1972 Ungdarella uralica; Homann, p. 155-156, 158, pl. 1, fig. 4.

1972 Ungdarella uralica; Mamet and Rudloff, p. 91, pl. 9, figs. 1-5.

1973 Ungdarella uralica; Kitaev, pl. 1, fig. 8. 

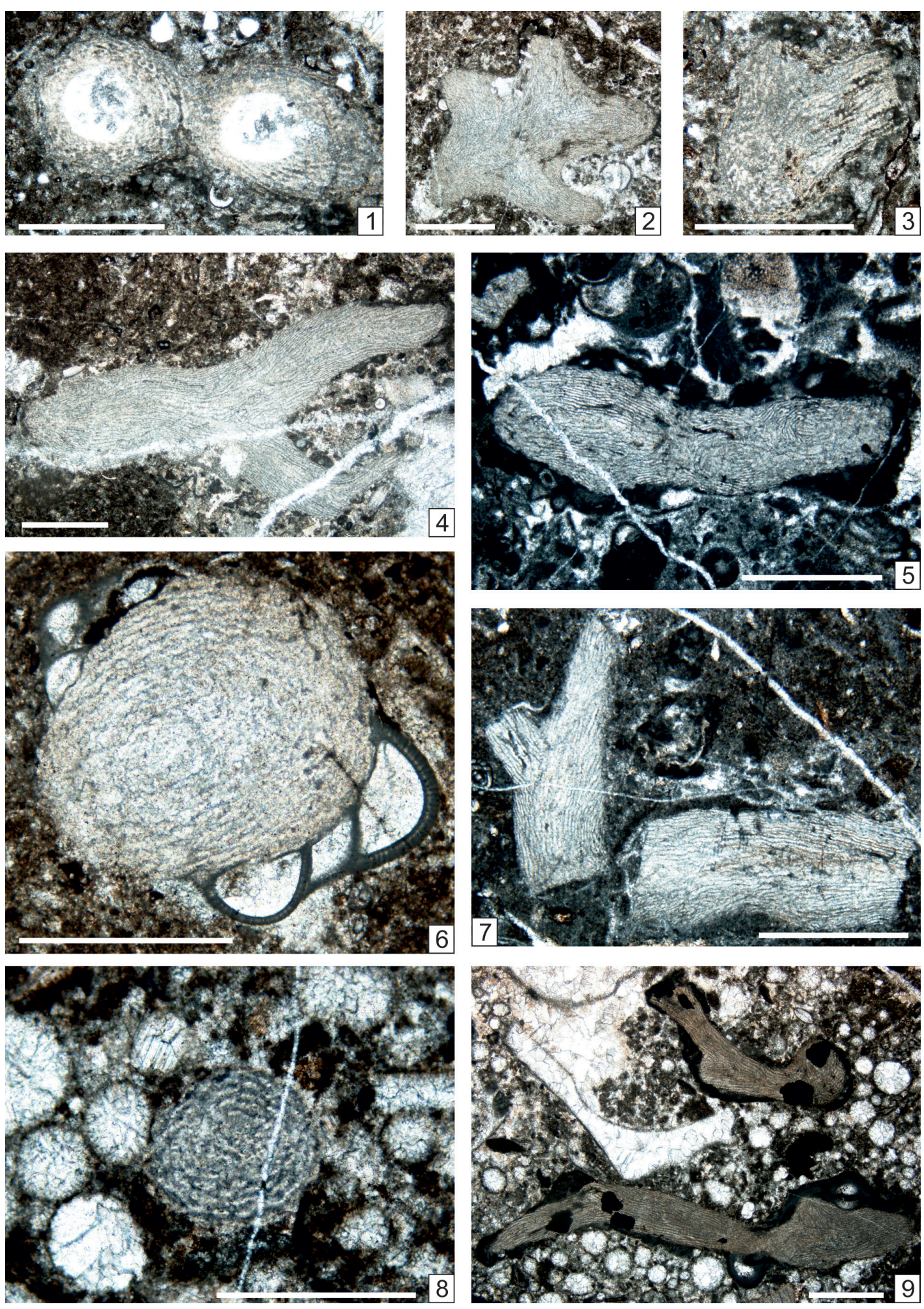

FIGURE 28. 1-9. Ungdarella uralica Maslov, 1956. Several oblique sections more or less recrystallized and one transverse section relatively well-preserved (Figure28.8). 1. Central parts of both branchs are chertified. Sample GB123_2a. 2. Sample GB125_2. 3. Sample GB 123_26. 4. Sample GB126_1. 5. Sample TNB15_1_1. 6. With Mendipsia conili (Nguyen Duc Tien, 1980). Sample GB130_5a. 7. Sample GBT13. 8. Sample ZK199_1. 9. Sample ZK200_10. Scale bars: Figure $28.7=1 \mu \mathrm{m}$; all others $=0.5 \mu \mathrm{m}$. 
1976 Ungdarella uralica; Emberger, p. 119 (no illustration) (with 21 references).

1977 Ungdarella uralica; Perret and Vachard, p. 120-121, pl. 5, fig. 4 (with 26 references in synonymy).

v1977a Ungdarella uralica; Vachard, p. 374, tabl. 1 p. 375 (no illustration).

1979 Ungdarella uralica; Flügel, p. 572 (no illustration).

1979 Ungdarella uralica; Zagorodnyuk, p. 11, pl. 3, fig. 3.

1979 Boundstone à Ungdarella uralica; Mamet et al., pl. 2, fig. 7 .

v1980 Ungdarella ex gr. uralica; Vachard, p. 405407, pl. 27, figs. 11-13, pl. 28, figs. 1, 2, 7, 9.

$1980 \quad$ Ungdarella uralica Maslov; Flügel and FlügelKahler, p. 161-162, pl. 8, fig. 4 (with six references in synonymy).

1980 Ungdarella uralica; Flügel and Flügel-Kahler, p. 161-162, pl. 8, fig. 4.

v1981 Ungdarella ex gr. uralica; Vachard in Vachard and Montenat, p. 65-66, pl. 11, figs. 1, 13.

1981 Ungdarella uralica; Mamet and Martínez, pl. 3, fig. 3.

1983 Ungdarella uralica; Mamet and Roux, p. 8586, pl. 8, figs. 7-10.

1986a Ungdarella uralica; Nguyen Duc Tien, pl. 10, fig. 1.

1986b Ungdarella uralica; Nguyen Duc Tien, pl. 14, fig. 1B, pl. 15, figs. 7,8 .

1986 Ungdarella uralica; Poncet, p. 189-190, pl. 2, figs. 4-6.

1987 Ungdarella uralica; Mamet et al., p. 52, pl. 25 , figs. $6-14$, pl. 26 , figs. $8-10$, pl. 27 , figs. 1, 9-11 (with 20 references).

1987 Ungdarella uralica; Chuvashov et al., pl. 21, fig. 1.

1987 Komia; Chuvashov et al., pl. 21, fig. 4.

1989 Ungdarella uralica; Sebbar and Lys, pl. 1, fig. 2.

1989 Ungdarella uralica; Nguyen Duc Tien, pl. 34, figs. 4,5 .

1989 Ungdarella ex gr. uralica; Köylüoğlu and Altıner, pl. 1, fig. 10.

v1990 Ungdarella uralica; Vachard and Miconnet, pl. 4, fig. 11.

$1990 \quad$ Ungdarella uralica; Flügel, pl. 3, fig. 5.

1996 Ungdarella; Madi et al., pl. 22, figs. 2, 5.

v.1998 Ungdarella uralica; Fontaine et al., p. 13 (no illustration).

v2001 Ungdarella uralica; Berkhli et al., p. 557, 558, 563, 565, text-fig. 6; fig. 5.9

v2001a Ungdarella ex gr. uralica; Vachard and Krainer, pl. 5, fig. 7.
2004 Ungdarella uralica; Mamet and Villa, tabl. 3 p. 157 , p. 169-170, fig. 14j (with 24 references in synonymy).

$2004 \quad$ Ungdarella sp.; Flügel, pl. 56, fig. 6.

$2006 \quad$ Ungdarella uralica; Mamet, p. 343, pl. 5, figs. 6-18 (with 24 references, including a mention of 20 other references in Mamet et al., 1987).

2007 Ungdarella uralica; Chuvashov and Anfimov, pl. 11, figs. 1, 2.

2008 Ungdarella uralica; Pille, p. 92-93, pl. 29, figs. $1-15$.

v2010 Ungdarella uralica; Vachard and Cózar, p. 200, text-figs $5.4,6.1-6.9$, pl. 11, figs. 12 , 13 ?, 14-20, pl. 12, figs. 1-5.

v.2011 Ungdarella sp.; Moix et al., p. 75, pl. 4, fig. 16c.

v.2011 Ungdarella uralica; Vachard and Moix, p. 157 (no illustration).

v2012 Ungdarella uralica; Kolodka et al., p. 138, 139, fig. 8i.

v2013 Ungdarella uralica; Parvizi et al., p. 167, figs. 9c, j, k, m (with six references in synonymy).

v2017 Ungdarella ex gr. uralica; Lucas et al., p. 15 (no illustration).

v2017a Ungdarella uralica; Krainer et al., p. 20, pl. 24 , figs. 2 , 3 , pl. 28 , figs. 6,7 , pl. 30 , fig. 11 , pl. 36, fig. 11.

Description. Length of fragments up to $6,000 \mu \mathrm{m}$; Diameter $=445-1,000 \mu \mathrm{m}$; weight of cells $?=5 \mu \mathrm{m}$; height of cells? $=3 \mu \mathrm{m}$; thickness of cells? $=10$ $\mu \mathrm{m}$.

Occurrence. As for the genus. In the Carnic Alps, Auernig Fm (Vachard and Krainer, 2001a); Zweikofel Fm (Flügel, 1968); Trogkofel Kalk of Forni Avoltri (Flügel and Flügel-Kahler, 1980); this study: Zweikofel Fm (samples GB123_2a; GB123 2b; GB125_2; GB126_1; GB130_5a; GB130_13b; ZK198_9; ZK199_1; ZK199_9; ZK200_2; ZK200_9; ZK200_10; ZK205_6); Zottachkopf Fm (samples TNB15_1_1; TNC7A_2); and Trogkofel Fm (sample GBT1_3).

Family STACHEIACEAE Loeblich and Tappan, 1961

emend. Vachard and Cózar, 2010, nom. correct. herein

Description. Aoujgaliales attached, showing many rows of quadratic cells or chamberlets with a uniseriate, partly overlapping growth. Chamberlets square or higher than wide with distal and proximal, curved sides and lateral sides rectilinear.

Occurrence. Late Viséan-Late Permian, probably cosmopolitan. 
Genus EFLUEGELIA Vachard in Massa and Vachard, 1979, emend. herein

Type species. Cuneiphycus johnsoni Flügel, 1966. Description. Test attached, elongate, with large uniseriate growth of chamber rows and asymmetrical growth. Chambers quadratic with curvated roofs and triangular pillars.

Remarks. Vachard and Cózar (2010) have synonymized Fourstonella and Efluegelia because, according to Groves (1986); Mamet and Villa (2004); and Cózar and Rodríguez (2004), the FAD of Efluegelia might be in the late Viséan. However, these latter Viséan specimens are most probably atypical specimens of Fourstonella (see the distinctive criteria of Vachard et al., 1989b: text-figure 3). Anyway, they differ from the type species Efluegelia johnsoni which is principally present and abundant in the Early Permian beds; i.e., long time after the LAD of the true Fourstonella in the Moscovian (Kabanov et al., 2006, plate 1, figure 9). This replacement occurs in identical microfacies and paleoecologic conditions. Hence, Fourstonella and Efluegelia are interpreted as two different genera, even if, of course, Fourstonella is the direct ancestor of Efluegelia.

Occurrence. Late Viséan-Late Permian with an acme in the Late Pennsylvanian and Early Permian; cosmopolitan.

Efluegelia johnsoni (Flügel, 1966) emend. Vachard in Massa and Vachard, 1979

Figure 29.10-11, Figure 30.3-4, 30.6-7

*1966 Cuneiphycus johnsoni Flügel, p. 17-19, pl. 2, figs. 1-5.

1968 Cuneiphycus johnsoni; Flügel p. 49, 55, 56 (no illustration).

1972 Cuneiphycus johnsoni; Homann, p. 167-169, pl. 2, fig. 12 (with five references).

1976 Cuneiphycus johnsoni; Emberger, p. 120 (bis) (no illustration; with six references).

?1978 Cuneiphycus johnsoni; Mamet and Roux, p. 83, pl. 7, figs. 11,12 (probably another genus).

?1979 Efluegelia johnsoni; Flügel, p. 572 (no illustration).

1979 Cuneiphycus johnsoni; Zagorodnyuk, p. 12, pl. 3, fig. 5 (sic; in reality, fig. 6).

$\mathrm{v}^{\star 1979}$ Eflugelia johnsoni; Massa and Vachard, p. 34.

1980 Efluegelia johnsoni; Flügel, pl. 7, fig. 6, pl. 9, fig. 1.

1980 Eflugelia johnsoni; Flügel and Flügel-Kahler, p. 163-164, pl. 8, figs. 9, 10 (with eight references in synonymy). v1980 Eflugelia johnsoni; Vachard, p. 396-397, pl. 5 , fig. 2 , pl. 23 , fig. 8 , pl. 25 , fig. 1 , pl. 27 , figs. $1-5,7,8$, pl. 34 , fig. 9 (with 18 references in synonymy).

vp1981 Eflugelia johnsoni; Vachard in Vachard and Montenat, p. 60, pl. 9, fig. 1, pl. 10, figs. 1-3, 5, 6, pl. 13 , fig. 2 (non pl. 12 , fig. $10=E$. ex gr. johnsoni).

1981 Efluegelia johnsoni; Ramovš and Kochansky-Devidé, p. 97-98, pl. 1, fig. 2.

1982 Efluegelia johnsoni; Milanović, p. 24-25, pl. 7, fig. 7, pl. 10, fig. 3.

non 1982 Cuneiphycus cf. Johnsoni (sic); Mu, p. 216, pl. 1, fig. 1 (= E. ex gr. johnsoni).

1983a Cuneiphycus johnsoni; Toomey, pl. 21, fig. 2.

v1984 Eflugelia johnsoni; Fontaine and Vachard, p. 51 (no illustration).

1985 Cuneiphycus johnsoni; Mu, p. 144-145, pl. 14, fig. 5.

1987 Cuneiphycus johnsoni; Mamet et al., p. 5556 , pl. 28, figs. 5-10.

v1989 Eflugelia johnsoni Flugel (sic, without parentheses and umlaut); Vachard in Fontaine and Gafoer, pl. 8, fig. 7.

v1989b Eflugelia johnsoni; Vachard et al., p. 707708, pl. 2, fig. 3 (with 15 references in synonymy).

non 1993 Eflügelia (sic) johnsoni; Chuvashov et al., pl. 13, fig. 11 (another species).

v1993b Eflugelia johnsoni; Vachard et al., pl. 2, figs. 6-8.

1995 Eflugelia johnsoni; Forke, p. 240, pl. 15, fig. 8.

v.1998 Eflugelia johnsoni; Fontaine et al., p. 13 (no illustration).

v2001a Eflugelia johnsoni; Vachard and Krainer, p. 151 (no illustration).

v2001b Eflugelia johnsoni; Vachard and Krainer, pl. 3, fig. 12.

v2003a Eflugelia johnsoni; Krainer et al, p. 18, 19, table 1 p. 18 , pl. 3 , figs. $9,17,37$, pl. 5 , figs. 20, 23-25, pl. 6, fig. 13, pl. 7, fig. 17.

v2003b Eflugelia johnsoni; Krainer et al, pl. 60, fig. 6.

2004 Fourstonella? johnsoni; Mamet and Villa, tabl. 3 p. 157 , p. $166-167$, fig. 14 f (with 28 references).

2004 Efluegelia Vachard; Flügel, pl. 56, fig. 5.

?2004 Efluegelia johnsoni; Cózar and Rodríguez, fig. 9.16 (most probably a broken Fourstonella).

2005 Fourstonella? johnsoni; Mamet and Zhu, fig. $5 \mathrm{~L}$.

v2009 Efluegelia johnsoni; Krainer et al., p. 13, 15, pl. 3, fig. 10. 

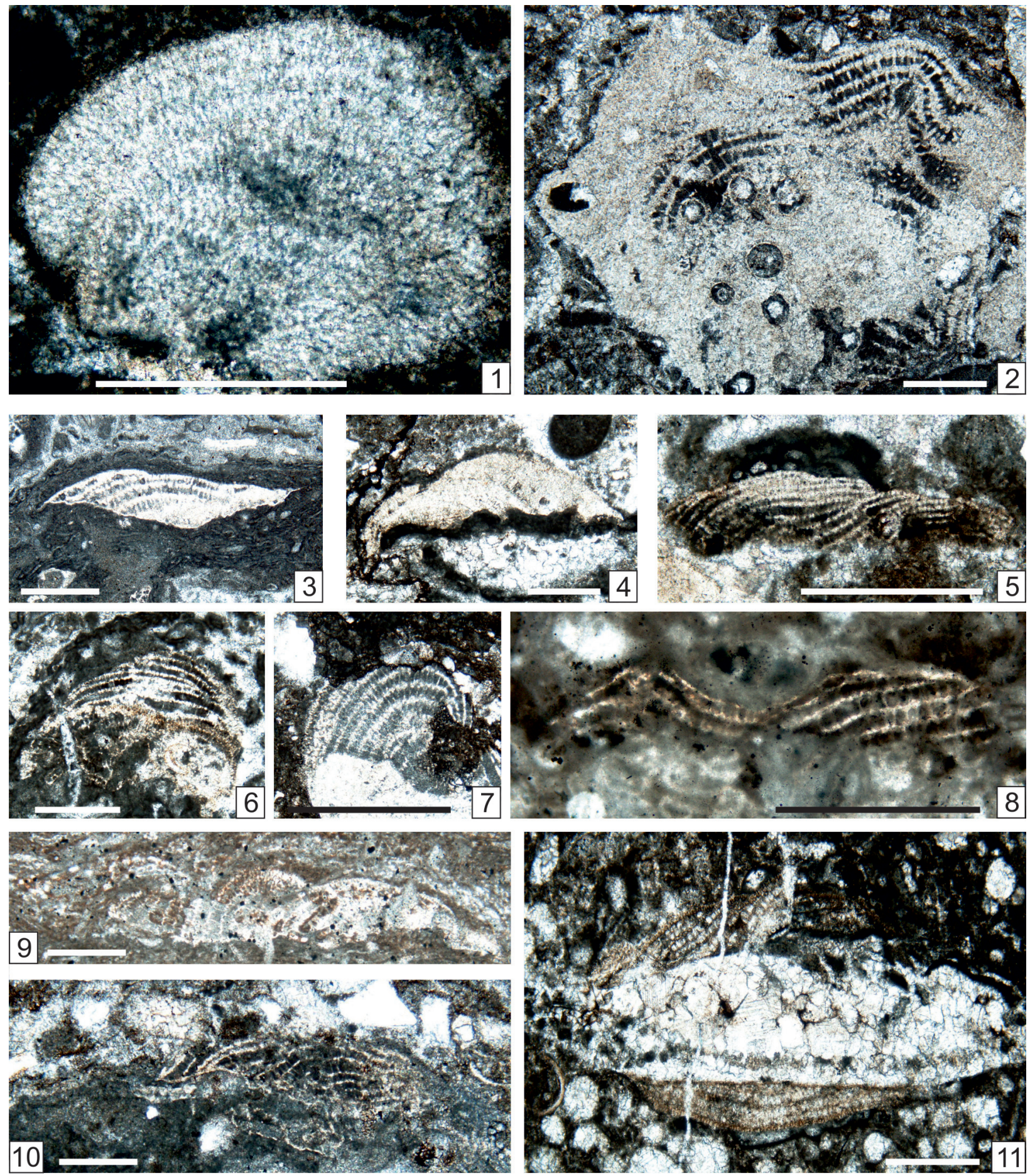

FIGURE 29. 1-9, 12. Efluegelia ex gr. johnsoni (Flügel, 1966). Various longitudinal and tangential sections. 1. Sample GB03_8. 2. Sample GB49_3. 3. Sample GB 56_2. 4. Sample GB_60_1_4. 5. Sample GB60_7a. 6. Sample GB60_4. 7. Sample GB68_6. 8. Sample TNB15_2_6. 9. Sample TK52_5. 12. Sample GB126_4. 10, 11. Efluegelia johnsoni (Flügel, 1966). 10. Sample GB109_4. 11. Sample GB117_1. Scale bars: Figures 29.6, $29.8=0.5 \mu \mathrm{m}$, all others $=1 \mu \mathrm{m}$. 
v2010 Fourstonella (= Efluegelia) johnsoni; Vachard and Cózar, p. 208, pl. 13, figs. 12, 16, 17, 20, 23, 27.

2010 Fourstonella johnsoni; Mamet and Préat, p. 22, pl. 6, figs. 7-14.

v2012 Efluegelia sp.; Kolodka et al., p. 138 (no illustration).

v2012 Fourstonella? (= Efluegelia) johnsoni; Vachard et al., p. 233, 235, 242-243, pl. 1, fig. 2, pl. 2, fig. 2.

v2013 Fourstonella (= Efluegelia) johnsoni; Vachard et al., p. 5, 7 (no illustration).

v2013 Fourstonella (= Efluegelia) johnsoni; Parvizi et al., p. 167, figs. 9d, 9g.

vp2015 Efluegelia johnsoni; Krainer et al., fig. 16.2 (only non figs. 22.20, $23.12=E$. ex gr. johnsoni).

v.2015 Efluegelia johnsoni; Lucas et al., figs. 12.14, 23.12.

v2015 Efluegelia johnsoni; Angiolini et al., table 2a.

v.2017a Fourstonella (Efluegelia) johnsonii; Krainer et al., p. 20 , pl. 52, fig. 6 .

Description. This taxon is well known in the USA (Toomey and Winland, 1973; Toomey, 1983a; Groves, 1983, 1986; Mamet et al., 1987; Krainer et al., 2003a, 2009; Vachard et al., 2012; Lucas et al., 2015). The dimensions of our specimens are consistent with Flügel's diagnosis: Length of remain = (420-600)-1,000-1,800 $\mu \mathrm{m}$; width of remain = (100-175)-330-1,000 $\mu \mathrm{m}$; intervals between pillars ("cell width") = 20-25 $\mu \mathrm{m}$; intervals between laminae ("cell height") $=15-20 \mu \mathrm{m}$; thickness of pillars and laminae $=5-7 \mu \mathrm{m}$; number of laminae: up to 10.

Occurrence. As for the genus. In the Carnic Alps: Rattendorf Group and Trogkofel Formation (Flügel, 1968); Forni Avoltri Goggau; Tarviser Brekzie (Flügel, 1979, 1980; Flügel-Kahler, 1980; Vachard and Krainer, 2001b: ZKO10); this study: Zweikofel Fm (samples GB49_3; GB60_1_3; GB60_1_4; GB72 6; GB60 4; GB60 7a; G̈B109 4; ZK95̄a-7; ZK99c_11; ZK179_1); Zottachkopf Fm (sample TKW13B_4); and Trogkofel Fm (sample GBT1_2).

\section{Efluegelia ex gr. johnsoni}

Figure 27.10-12, Figure 29.1-9, Figure 30.1-2, 30.5, 30.8-11

?1974 Cuneiphycus johnsoni Flügel; Chuvashov, p. 34 , pl. 21, figs. 1-8.

$1980 \quad$ No legend; Flügel, pl. 9, fig. 1.

vp1981 Eflugelia johnsoni; Vachard in Vachard and Montenat, p. 60, pl. 12, fig. 10 (only; non pl. 9 , fig. 1 , pl. 10 , figs. $1-3,5,6$, pl. 13 , fig. $2=$ E. johnsoni).
1982

Cuneiphycus cf. Johnsoni (sic) E. Flügel; Mu, p. 216, pl. 1, fig. 1.

1985 Cuneiphycus cf. johnsoni; Mu, p. 144-145, pl. 14, fig. 6.

vp2015 Efluegelia johnsoni; Krainer et al., figs. 22.20, 23.12 (only; non fig. $16.2=$ E. johnsoni).

v2015 Efluegelia johnsoni; Lucas et al., figs. 12.14, 23.12.

Description. Thalli? encrusting flat or nearly flat objects. Numerous laminar layers of quadratic cells. $L=950-3,000 \mu \mathrm{m} ; \mathrm{H}=500-2,160 \mu \mathrm{m}$; interlaminar height $(=$ heigth of cells $)=30-100 \mu \mathrm{m}$; interpillar distance (= width of cells) $=20-60 \mu \mathrm{m}$; number of laminae: up to 20-25.

Comparison. Efluegelia ex gr. johnsoni differs from typical $E$. johnsoni by a higher number of laminae, and parameters that are all larger.

Occurrence. ?Asselian of the Urals (Chuvashov, 1974). Early Permian of South China (Mu, 1982, 1985) and Afghanistan (Vachard and Montenat, 1981). In the Carnic Alps (this study): uppermost Grenzland Fm (samples GB03_8; GB19_1b); Zweikofel Fm (samples GB49_3; GB56_2; GB_60_1_4. 5; GB60_7a; GB60_4; GB68_6; GB73_A; GB117_1; GB126_4; GB157_10; GB162_1; GB174_5̄; GB174_11); Zottachkopf Fm (samples TKW9_6; Z6_1; Z15_3; Z17B_1; ZK95_gross_3; ZK95a_7; ZK96_3; ZK187_5; ZK199. 11; ZK200_1; ZKa_5); basal Trogkofel Fm (sample GBT1_2); and Trogkofel Fm (samples TNB15.2.6; TK11_2_2; TK52_5).

\section{CONCLUSIONS}

1) A local, morphological classification of the cyanobacteria is attempted, from coccoid individuals to hemispherical colonies of bifurcated filaments, with the possible order: 1) coccoid thalli (incerti ordinis 1; probably Chroococcales); 2) filamentous and/or coccoid, stromatolitic and microbialitic taxa (incerti ordinis 2: stromatolites sensu lato); 3) carbonate stromatolitic textures (incerti ordinis 3; family Aphralysiaceae); 4) colonial coccoid? textures (incerti ordinis 4; family Chabakoviaceae); 5) tubular, single filaments (order Proauloporales or Oscillatoriales?; family Girvanellaceae); 6) colonial groups of filaments (order Proauloporales or Oscillatoriales; family Garwoodiaceae).

2) Some taxa are rare or not mentioned in the Lower Permian deposits: Nostocites, Renalcis, Gahkumella, Mitcheldeania and Garwoodia. Others are better known: Archaeolithoporella, Girvanella, and Koivaella.

3) The rare red algae are recrystallized Parachaetetes and Archaeolithophyllum lamellosum, that are probably reaching their LAD. 

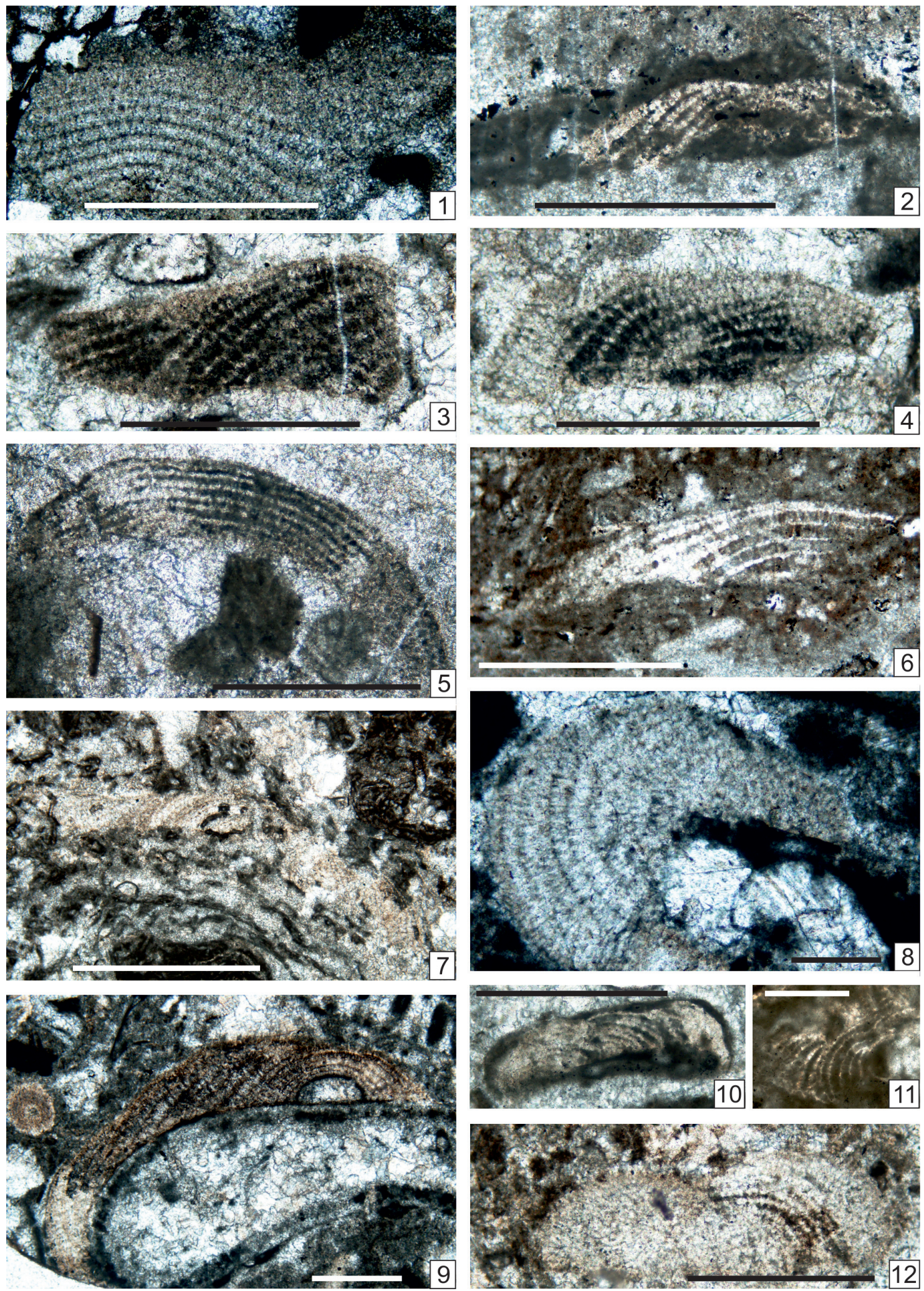

FIGURE 30. 1, 2, 5, 8-11. Efluegelia ex gr. johnsoni (Flügel, 1966). Various longitudinal and tangential sections 1. Sample GBT1_2. 2. Sample TKW9_6. 5. Sample ZK187_5. 8. Sample ZK95_gross_3. 9. Sample ZKa_5. 10. Sample ZK199. 11. Sample ZK200_1. 3, 4, 6, 7. Efluegelia johnsoni (Flügel, 1966). 3. Sample TKW138_4. 4. Sample Z6_1. 6. Sample Z15_3_4. 7. Sample GB174_5. Scale bars: Figures 30.8, 30.9, 30.10 $=0.2 \mu \mathrm{m}$, all others $=0.5 \mu \mathrm{m}$. 
4) The descriptions of Homannisiphon morikawaii are confirmed. This alga is not entirely endemic (it exists probably in Iran), but is rare outside of the Carnic Alps.

5) The phylloid algae are taxomomically revised. They constitute the family Anchicodiaceae emend. with the unique tribe Anchicodiae $\mathrm{n}$. trib. (replacing Ivanoviae nom. vanum). The taxa of the Carnic Alps are: Anchicodium japonicum; Ivanovia tenuissima; Eugonophyllum magnum; E.? konishi; Calcipatera schoenlaubi n. sp., and Neoanchicodium catenoides. The other phylloid algae mentioned in the Carnic Alps were not re-found during this study.

6) The tribe Anthracoporellae n. trib. is described herein. Anthracoporella is discussed, with $A$. spectabilis, rare in our material, and $A$. vicina more common.

7) Other aspondyl dasycladales are rare Macroporella sp.

8) An accurate taxonomic revision of the epimastoporacean dasyclales is also undertaken in this paper. Parapimastopora is rare; Epimastopora is emended with Epimastopora japonica Endo subsequently designated as type species. Other "Epimastopora" are assigned to a new genus: Epiastopora, with Epimastopora alpina as type species. The type species of Globuliferoporella is re-designated with $E$. piai, because
G. symmetrica originally designated as type species is actually a Gyroporella.

9) In constrast to the previous studies, the genus Gyroporella is rare in our material.

10) The genus Pseudoepimastopora, revised in relation to our studies of the epimastoporaceans, is revised and, unexpectedly is discovered to be the genus corresponding to the disputed "Atractyliopsis" carnica Flügel.

11) Some data are provided on the three species of Mizzia: M. velebitana, M. yabei and M. cornuta.

12) The unique complex dasycladale is Connexia slovenica, which corresponds exactly to the previous descriptions.

13) Among the Algospongia (incertae sedis algae), classical taxa have been found: Claracrusta ex gr. catenoides; Ungdarella ex gr. uralica; and Efluegelia johnsoni.

\section{ACKNOWLEDGMENTS}

This study was funded by Project P20178N10 of the Austrian Science Foundation (FWF). The authors wish to thank D. Hembree, D. Nowakowski and an anonymous reviewer for their constructive criticisms which improved an earlier draft of the manuscript. We appreciate the technical help of T. Vachard, S. Clausen and J. Cuvelier (Université de Lille, Villeneuve d'Ascq) and F. Le Coze (Saint-Etienne).

\section{REFERENCES}

Accordi, B., 1956. Calcareous algae from the Upper Permian of the Dolomites (Italy) with stratigraphy of the "Bellerophon-Zone". Journal of the Palaeontological Society of India, 1:75-84.

Adams, A.E. and Al-Zahrani, M.S. 2000. Palaeoberesellids (Dasycladaceans) from the Upper Jurassic Arab-D reservoir, Saudi Arabia. Palaeontology, 43:591-597. https://doi.org/10.1111/ j.0031-0239.2000.00142.x

Aguirre, J. and Barattolo, F. 2001. Presence of nemathecia in Parachaetetes asvapatii Pia, 1936 (Rhodophyta, Gigartinales?): Reproduction in "Solenoporaceans" revisited. Palaeontology, 44:1113-1125. https://doi.org/10.1111/1475-4983.00217

Aizenverg, D.E., Astakhova, T.V., Berchenko, O.I., Brazhnikova, N.E., Vdovenko, M.V., Dunaeva, N.N., Zernetskaya, N.V., Poletaev, V.I., and Sergeeva, M.T. 1983. Verkhneserpukhovskii podyarus Donetskogo basseina. Akademiya Nauk Ukrainskoi SSR, Institut Geologicheskii Nauk, Kiev. (In Russian)

Angiolini, L., Campagna, M., Borlenghi, L., Grunt, T., Vachard, D., Vezzoli, G., Vuolo, I., Worthington, J., Nicora, A., and Zanchi, A. 2016. Brachiopods from the CisuralianGuadalupian of Darvaz, Tajikistan and implications for Permian stratigraphic correlations. Palaeoworld, 25:539-568. https://doi.org/10.1016/j.palwor.2016.05.006

Angiolini, L., Carabelli, L., Nicora, A., Crasquin-Soleau, S., Marcoux, J., and Rettori, R. 2007. Brachiopods and other fossils from the Permo-Triassic boundary beds of the Antalya Nappes (SW Taurus, Turkey). Geobios, 40:715-729. https://doi.org/10.1016/j.geobios.2007.01.007 
Angiolini, L., Checconi, A., Gaetani, M., and Rettori, R. 2010. The latest Permian mass extinction in the Alborz mountains (North Iran). Geological Journal, 45:216-229. https://doi.org/ 10.1002/gj.1203

Angiolini, L., Zanchi, A., Zanchetta, S, Nicora, A., Vuolo, I., Berra, F., Henderson, C., Malaspina, N., Rettori, R., Vachard, D., and Vezzoli, G. 2015. From rift to drift in South Pamir (Tajikistan): Permian evolution of a Cimmerian terrane. Journal of Asian Earth Sciences, 102:146-169; https://doi.org/10.1016/j.jseaes.2014.08.001

Antropov, I.A. 1955. Sinezelenye vodorosli devona tsentralnykh raionov vostoka Russkoi platformy. Uchenie Zapiski Kazansky Institute Obshch Estest Trudy, 115:41-53. (In Russian)

Baars, D.L. 1992. Kansaphyllum, a new Late Pennsylvanian phylloid algal genus. Journal of Paleontology, 66:697-701. https://doi.org/10.1017/s0022336000024628

Baars, D.L. and Torres, A.M. 1991. Late Paleozoic phylloid algae - A pragmatic review. Palaios, 6:513-515. https://doi.org/10.2307/3514989

Babcock, J.A. 1979. Calcareous algae and algal problematica of the Capitan Reef (Permian), Guadalupe Mountains, West Texas and New Mexico, U.S.A. Bulletin des Centres de Recherche et Exploration-Production Elf-Aquitaine, 3:419-428.

Barattolo, F. 1982. Osservazioni su Triploporella apenninica Baretti, 1922 (alghe verdi, dasicladali) del Paleocene dell'Abruzo Aquilano. Geologica Romana, 21:29-59.

Barattolo, F. 1983. Osservazioni su Triploporella steinmannii n. sp. (alghe verdi, Dasicladali) del Cretacico del Messico. Bollettino della Società dei Naturalisti in Napoli, 91:1-35.

Barattolo, F., De Castro, P., and Parente, M. 1993. Some remarks on Griphoporella curvata (Gümbel 1872) Pia 1915, dasycladacean alga from the upper Triassic, p. 23-45. In Barattolo, F., De Castro, P., and Parente, M. (eds.), Studies on Fossil Benthic Algae. Bollettino della Società Paleontologica Italiana, special volume 1, Roma.

Bassoullet, J.P., Bernier, P., Deloffre, R., Génot, P., Jaffrezo, M., and Vachard, D. 1979. Essai de classification des Dasycladales en tribus. Bulletin Centres Recherche Exploration-Production Elf-Aquitaine, 3:429-442.

Bassoullet, J.P., Bernier, P., Deloffre, R., Génot, P., Poncet, J., and Roux, A. 1983. Les algues Udotéacées du Paléozoïque au Cénozoïque. Bulletin Centres Recherche ExplorationProduction Elf-Aquitaine, 7:429-621.

Bebout, D.G. and Coogan, A.H., 1964. Algal genus Anthracoporella Pia. Journal of Paleontology, 38:1093-1096.

Bensing, J.P. 2007. An Early Permian subtropical carbonate system: Sedimentology and diagenesis of the Raanes and Great Bear Cape formations, Sverdrup Basin, Arctic Canada. Unpublished PhD thesis, Queen's University, Kingston, Ontario, Canada.

Berchenko, O.I. 1982. Novye vidy zelenykh vodoroslei iz otlozhenii verkhneserpukhovskogo podyarusa Donbassa, p. 51-54. In Teslenko, Yu.V. (ed.), Sistematika i Evolyutsia Drevnikh Rastenii Ukrainy. Naukova Dumka, Kiev. (In Russian)

Bérczi-Makk, A. and Kochansky-Devidé, V. 1981. Marine Lower and Middle Permian in the oil exploratory well Ujfalu-I (SW-Hungary). Acta Geologica Academiae Scientarum Hungaricae, 24:117-128.

Berkhli, M., Vachard, D., and Paicheler, J.C. 2001. Les séries du Carbonifère inférieur de la série d'Adarouch, NE du Maroc central: Lithologie et biostratigraphie. Journal of African Earth Sciences, 32:557-571. https://doi.org/10.1016/s0899-5362(02)00040-4

Bessey, C.E. 1907. A synopsis of plant phyla. University Studies of the University of Nebraska, 7:275-373.

Bignot, G. 1972. Recherches stratigraphiques sur les calcaires du Crétacé supérieur et de l'Eocène d'Istrie et des régions voisines. Essai de révision du Liburnien. Travaux du Laboratoire de Micropaléontologie, Université Paris VI, 2:1-353.

Bilgütay, U. 1960. Some Permian calcareous algae from the vicinity of Ankara. Bulletin of the Mineral Research and Exploration Institute of Turkey, 54:52-65.

Boeckelmann, K. 1985. Mikrofazies der Auernig-Schichten und Grenzland-Bänke westlich des Rudnig-Sattels (Karbon-Perm; Karnische Alpen). Facies, 13:155-174. https://doi.org/ 10.1007/bf02536902

Bogush, O.I., Ivanova, R.M., and Luchinina, V.A. 1990. Izvestkovye Vodorosli Verkhnego Famena i Nizhnego Karbona Urala i Sibiri. Akademiya Nauk SSSR, Sibirskoe Otdelenie, Trudy Instituta Geologii i Geofiziki, 745:1-160. (In Russian) 
Bowsher, A.L. 1986. Late Paleozoic reef complexes of the northern Sacramento Mountains, New Mexico. American Association of Petroleum Geologists, Southwestern Section, 1986, Transactions and Guidebook: 49-72.

Bozorgnia, F. 1973. Paleozoic foraminiferal biostratigraphy of central and east Alborz Mountains, Iran. National Iranian Oil Company, Geological Laboratories, Publication 4:1-185.

Brady, H.B. 1878. On the reticularian and radiolarian Rhizopoda (Foraminifera and Polycystina) on the North Polar Expedition of 1875-76. Annals and Magazine of Natural History, Series 5, 1:425-440.

Brenckle, P.L. 2004. Late Viséan (Mississippian) calcareous microfossils from the Tarim Basin of western China. Journal of Foraminiferal Research, 34:144-164. https://doi.org/10.2113/ 0340144

Bucur, I.I. 1994. Lower Cretaceous Halimedaceae and Gymnocodiaceae from southern Carpathians and Apouseni Mountains (Romania) and the systematic position of the Gymnocodiaceae. Beiträge zur Paläontologie, 19:13-37.

Bucur, I.I. and Enos, P. 2001. Middle Triassic dasyclad algae from Guizhou, China. Micropaleontology, 47:317-338. https://doi.org/10.2113/47.4.317

Bucur, I.I., Kiessling, W., and Scasso, R.A. 2004. Re-description and neotypification of Archamphipora jurassica Steinmann 1930, a calcareous alga from the Jurassic of Argentina. Journal of Paleontology, 83:962-968. https://doi.org/10.1666/09-052.1

Bucur, I.I., Munnecke, A., Granier, B., and Yan, J.X. 2009. Remarks on the Permian dasycladalean alga Sinoporella leei, Yabe 1949. Geobios, 42:221-231. https://doi.org/ 10.1016/j.geobios.2008.10.004

Buggisch, W., Flügel, E., Leitz, F., and Tietz, G.-F. 1976. Die fazielle und paläogeographische Entwicklung im Perm der Karnischen Alpen und in den Randgebieten. Geologische Rundschau, 65:649-690. https://doi.org/10.1007/bf01808485

Buttersack, E. and Boeckelmann, K. 1984. Palaeoenvironmental evolution during the Upper Carboniferous and the Permian in the Schulter-Trogkofel area (Carnic Alps, northern Italy). Jahrbuch der Geologischen Bundesanstalt, 126:349-358.

Camoin, G. 1989. Biological communities in lower Senonian carbonate buildups from Jebel Bou Zer (Central Tunisia). Atti $3^{\circ}$ Simposio di Ecologia e Paleoecologia delle Communità bentoniche Catanaia-Taormina, 1985, Catanaia-Taormina, p. 333-358.

Caridroit, M., Fontaine, H., Jongkanjanasoontorn, Y., Suteethorn, V., and Vachard, D. 1990. First results of a paleontological study of Northwest Thailand, p. 337-350. In Fontaine H. (ed.), Ten Years of CCOP Research on the Pre-Tertiary of East Asia. CCOP Technical Publications, 20, Bangkok and Tokyo.

Cavalier-Smith, T. 1998. A revised six-kingdom system of life. Biological Reviews of the Cambridge Philosophical Society, 73:203-266. https://doi.org/10.1017/s0006323198005167

Cavalier-Smith, T. 2002. The phagotrophic origin of eukaryotes and phylogenetic classification of Protozoa. International Journal of Systematic and Evolutionary Microbiology, 52:297-354. https://doi.org/10.1099/00207713-52-2-297

Chanton, N. 1966. Nouvelle contribution à l'étude des algues calcaires du Carbonifère saharien. Bulletin de la Société Géologique de France (7), 7(1965):402-409.

Chanton-Güvenç, N. 1972. Présence d'Algues calcaires dans le Carbonifère marocain. Bulletin de la Société Géologique de France (7), 13(1971):187-194.

Chen Z.Q., Shi, Guang R., and Yang, W.R. 2003. Internal structure and paleoecology of the Lower Permian Uzunbulak Reef complex of the Tarim Basin, Northwest China. Facies, 49:119-134.

Cherchi, A. and Schroeder, R. 1979. Koskinobullina n. gen., micro-organisme en colonie incertae sedis (algues?) du Jurassique-Crétacé de la région méditerranéenne, note préliminaire. Bulletin des Centres de Recherche Exploration-Production Elf-Aquitaine, 3:519-523.

Choquette, P.W. 1983. Platy algal reef mounds, Paradox Basin, p. 454-462. In Scholle, P.A., Bebout, D.G., and Moore, C.H. (eds.), Carbonate Depositional Environments. American Association of Petroleum Geologists, Memoir 33, Tulsa.

Chuvashov, B.I. 1974. Permskie izvestkovye vodorosli Urala, p. 3-52. In Papulov, G.N. and Chuvashov, B.I. (eds.), Vodorosli, Brakhiopodi i Miospory iz Permskikh Otlozhenii Zapadnogo Urala. Trudy Instituta Geologii i Geokhimii, 109. Akademiya Nauk SSSR, Uralskii Nauchnyi Tsentr, Sverdlovsk. (In Russian) 
Chuvashov, B.I. 2001. Taxonomy, biostratigraphy and biogeography of the Permian Mizzia-like calcareous algae (Dasycladales, Cyclocrinaceae). Paleontological Journal (English translation), 35(1):97-104.

Chuvashov, B.I. and Anfimov, A.L. 1988. Novye izvestkovye vodorosli srednego karbonanizhnei permi Urala i Priuralya, p. 54-70. In Zhuravleva, I.T. and Puchkov, V.M. (eds.), Izvestkovye Vodorosli i Stromatolity. Akademiya Nauk SSSR, Sibirskoe Otdelenie, Instituta Geologii i Geofiziki, "Nauka”, Sverdlovsk. (In Russian)

Chuvashov, B.I. and Anfimov, A.L. 2001. Specific features of carbonate platform formation: Evidence from the Middle Carboniferous East Ural Gulf. Lithology and Mineral Resources, 36:211-233 (English translation).

Chuvashov, B.I. and Anfimov, A.L. 2007. On the taxonomy of the Paleozoic red algae of the family Ungdarellaceae. Paleontological Journal, 41:95-102 (English translation). https:// doi.org/10.1134/s0031030107010108

Chuvashov, B. and Riding, R. 1984. Principal floras of Palaeozoic marine calcareous algae. Palaeontology, 27:487-500.

Chuvashov, B.I., Luchinina, V.A., Shuysky, V.P., Shaikin, I.M., Berchenko, O.I., Ishchenko, A.A., Saltovskaya, V.D., and Shirshova, D.I. 1987. Iskopaemye Izvestkovye Vodorosli, Morfologiya, Sistematika, Metody Izucheniya. Akademiya Nauk SSSR, Sibirskoe Otdelenie, Trudy Instituta Geologii i Geofiziki, 674:5-224, Moscow. (In Russian)

Chuvashov, B.I., Shuysky, V.P., and Ivanova, R.M. 1993. Stratigraphical and facies complexes of the Paleozoic calcareous algae of the Urals, p. 93-119. In Barattolo, F., De Castro, P., and Parente, M. (eds.), Studies on Fossil Benthic Algae. Bolletino della Società Paleontologica Italiana, Special Volume 1, Modena.

Colin, J.P. and Vachard, D. 1977. Une "Girvanelle" dulçaquicole du Cénomanien du Sud-Ouest de la France: Girvanella (?) palustris Colin et Vachard n. sp. Review of Paleobotany and Palynology, 23: 293-302. https://doi.org/10.1016/0034-6667(77)90054-9

Corrochano, D., Vachard, D., and Armenteros, I. 2013. New insights on the red alga Archaeolithophyllum from the Pennsylvanian of the Cantabrian Zone (NW Spain). Facies, 59:949-967. https://doi.org/10.1007/s10347-012-0347-8

Cózar, P. 2004. Foraminiferal and algal evidence for the recognition of the Asbian/Brigantian boundary in the Guadiato Area (Mississippian, Southwestern Spain). Revista Española de Micropaleontología, 36: 367-388.

Cózar, P. 2005. Early Serpukhovian (late Mississippian) microflora from the Guadiato area (southwestern Spain). Geological Journal, 40:405-424. https://doi.org/10.1002/gj.1014

Cózar, P., Medina-Varea, P., Somerville, I.D., Vachard, D., Rodríguez, S., and Said, I. 2014. Foraminifers and conodonts from the late Viséan to early Bashkirian succession in the Saharan Tindouf Basin (southern Morocco): Biostratigraphic refinements and implications for correlations in the western Palaeotethys. Geological Journal, 49: 271-302. https://doi.org/ 10.1002/gj.2519

Cózar, P. and Rodríguez, S. 2004. Pendleian (early Serpukhovian) marine carbonate from SW Spain: sedimentology, biostratigraphy and depositional model. Geological Journal, 39:25-47. https://doi.org/10.1002/gj.942

Cózar, P., Rodríguez, S., and Somerville, I.D. 2003. Large multi-biotic cyanoliths from relatively deep-water facies in the early Serpukhovian of SW Spain. Facies, 49:31-48.

Cózar, P. and Somerville, I.D. 2004. New algal and foraminiferal assemblages and evidence for recognition of the Asbian/Brigantian boundary in northern England. Proceedings of the Yorkshire Geological Society, 55:43-65. https://doi.org/10.1144/pygs.55.1.43

Cózar, P. and Somerville, I.D. 2005a. Stratigraphy of upper Viséan carbonate platform rocks in the Carlow area, southeast Ireland. Geological Journal, 40:35-64. https://doi.org/10.1002/ gj. 984

Cózar, P. and Somerville, I.D. 2005b. Significance of calcareous algae for the recognition of the Asbian and Brigantian stages (Mississippian) in Ireland and Great Britain. Revista Española de Micropaleontología, 37:71-94.

Cózar, P., Somerville, I.D., Blanco-Ferrera, S., and Sanz-López, J. 2018. Palaeobiogeographic context in the development of shallow-water late Viséan-early Bashkirian benthic foraminifers and calcareous algae in the Cantabrian Mountains (Spain). Palaeogeography,

Palaeoclimatology, Palaeoecology, 511:20-638. https://doi.org/10.1016/ j.palaeo.2018.09.031 
Cózar, P., Somerville, I.D., and Burgess, I. 2010. Foraminiferal, calcareous algal and problematica assemblages from the Mississippian Lower Limestone Formation in the Midland Valley, Scotland. Earth and Environmental Science Transactions of the Royal Society of Edinburgh, 100:297-309. https://doi.org/10.1017/s1755691010008029

Cózar, P., Somerville, I.D., and Medina-Varea, P. 2005. Note on the earliest occurrences of the calcareous algae Paraepimastopora and Archaeolithophyllum in Mississippian rocks. Coloquios de Paleontología, 55:7-20.

Cózar, P., Somerville, I.D., Rodríguez, S., and Medina-Varea, P. 2007. New genera of late Viséan metaspondil dasycladales from the Fuenteobejuna section (Mississippian of the Guadiato Valley, southwestern Spain). Neues Jahrbuch für Geologie und Paläontologie Abhandlungen, 246:97-109. https://doi.org/10.1127/0077-7749/2007/0246-0097

Cózar, P. and Vachard, D. 2004. A new Mississippian dasyclad alga (Chlorophyta) from SW Spain: Implications for the reproductive evolution of the dasyclads during the Late Paleozoic. Eclogae geologicae Helvetiae, 97:175-181. https://doi.org/10.1007/s00015-004-1127-4

Cys, J.M. and Mazzullo, S.J. 1977. Biohermal submarine cements, Laborcita Formation (Permian), northern Sacramento Mountains, New Mexico, p. 39-51. In Butler, J. (ed.), Geology of the Sacramento Mountains, Otero County, New Mexico. West Texas Geological Society Publication, 77-68. Midland.

Davies, G.R., Richards, B.C., Beauchamp, B., and Nassichuk, W.W. 1989. Carboniferous and Permian Reefs in Canada and adjacent areas, p. 565-574. In Geldsetzer, H.H.J., James, N.P., and Tebbutt, G.E. (eds.), Reefs, Canada and Adjacent Areas. Canadian Society of Petroleum Geologists, Memoir 13. Calgary.

Davydov, V. and Krainer, K. 1999. Fusulinid assemblages and facies of the Bombaso Fm and basal Meledis Fm. (Moscovian-Kasimovian) in the central Carnic Alps (Austria/ltaly). Facies, 40:157-196. https://doi.org/10.1007/BF02537473

Davydov, V.I., Krainer, K., and Chernykh, V. 2013. Fusulinid biostratigraphy of the Lower Permian Zweikofel Formation (Rattendorf Group; Carnic Alps, Austria) and Lower Permian Tethyan chronostratigraphy. Geological Journal, 48:57-100. https://doi.org/10.1002/gj.2433

Dawson, O. 1993. Fusiline foraminiferal biostratigraphy and carbonate facies of the Permian Ratburi Limestone, Saraburi, central Thailand. Journal of Micropalaeontology, 12:9-33. https://doi.org/10.1144/jm.12.1.9

Dawson, W.C. 1992. Phylloid algal microstructures enhanced by epifluorescence petrography. Journal of Paleontology, 66:523-525. https://doi.org/10.1017/s0022336000034053

Dawson, W.C. and Carozzi, A.V. 1986. Anatomy of phylloid algal buildup, Raytown Limestone, lola Formation, Pennsylvanian, southeast Kansas, U.S.A. Sedimentary Geology, 47:221261. https://doi.org/10.1016/0037-0738(86)90085-0

De Castro, P. 1982. Osservazioni su Triploporella steinmannii n. sp. (alghe Verdi, Dasicladali) del Cretacico del Messico. Bollettino della Società dei Naturalisti in Napoli, 91:1-21.

De Castro, P. 1997. Introduzione allo studio in sezione sottile delle Dasicladali fossili (An approach to thin-section study of fossil dasycladales). Quaderni Accademia Pontiana, 22:1261.

De Castro, P. 2002. Remarks on Anthracoporella spectabilis Pia, 1920, a supposed PermianCarboniferous dasyclad. Bollettino della Società Paleontologica Italiana, 41:3-12.

De Castro, P. and Sirna, G. 1996. The Durania arnaudi biostrome of El-Hassana, Abu Roash area (Egypt). Geologica Romana, 3:69-91.

Deloffre, R. 1987. Nouvelle classification des algues Dasycladales fossiles. Comptes Rendus de l'Académie des Sciences, 305, série II:1017-1020.

Deloffre, R. 1988. Nouvelle taxonomie des algues dasycladales. Bulletin des Centres de Recherche Exploration-Production Elf-Aquitaine, 12:165-217.

Deloffre, R. 1992. Révision des Gymnocodiaceae (algues rouges Permien-Miocène). Taxonomie, biostratigraphie, paléobiogéographie, 3e partie: Taxonomie, Biostratigraphie, Paléobiogéographie. Revue de Micropaléontologie, 35:23-37.

Delvolvé, J.J. and Perret, M.F. 1987. Foraminifères, algues et conodontes bashkiriens dans le culm des Pyrénées béarnaises. Geobios, 20:193-213. https://doi.org/10.1016/s00166995(87)80034-7

Delvolvé, J.J., Perret, M.F., and Vachard, D. 1987. Découverte du Kachirien (Moscovien inférieur) à fusulines et algues dans le massif de Cinco Villas (Pyrénées basques, Espagne). Geobios, 20:541-548. https://doi.org/10.1016/s0016-6995(87)80087-6 
Deninger, K. 1906. Einige neue Tabulaten und Hydrozoen aus den mesozoischen Ablagerungen. Neues Jahrbuch für Mineralogie, Geologie und Paläontologie, 1:61-70.

Desmazières, J.B.H.J. 1830. Catalogue des plantes omises dans la botanographie de la Belgique et dans les flores du nord de la France: ou, énumération des végétaux phanérogames et cryptogames qui croissent spontanément dans la Belgique ancienne, et qui n'ont point été connus ou décrits par tous les auteurs du pays. Ouvrage dans lequel on trouve l'indication exacte des lieux où ces végétaux peuvent être observés, l'époque précise de leur floraison, et l'exposition des caractères essentiels des espèces présentées aux botanistes comme tout-à-fait nouvelles. Annales de la Société des Sciences Natuelles, Botanique, 19:269-279.

Devuyst, F.X. 2006. The Tournaisian-Viséan Boundary in Eurasia. Definition, Biostratigraphy, Sedimentology and Early Evolution of the Genus Eoparastaffella (foraminifer). Unpublished PhD Thesis, Université Catholique de Louvain, Louvain-la-Neuve.

Elenkin, A.A. 1934. Ob Osnovych Principach Sistemy Cyanophyceae. Soveskaya Botanica, Institut Akademii Nauk SSR,1934:51-83, Moscow. (In Russian)

Elliott, G.F. 1955. The Permian calcareous alga Gymnocodium. Micropaleontology, 1:83-90. https://doi.org/10.2307/1484413

Elliott, G.F. 1956. Further records of fossil calcareous algae from the Middle East. Micropaleontology, 2:327-334. https://doi.org/10.2307/1484348

Elliott, G.F. 1958. Fossil microproblematica from the Middle East. Micropaleontology, 4:419-428. https://doi.org/10.2307/1484269

Elliott, G.F. 1960. Fossil calcareous algal floras of the Middle East with a note on a Cretaceous problematicum, Hensonella cylindrica gen. et sp. nov. Quarterly Journal Geological Society London, 115:217-232. https://doi.org/10.1144/gsl.jgs.1959.115.01.11

Elliott, G.F. 1968a. Permian to Palaeocene calcareous algae (Dasycladaceae) of the Middle East. Bulletin of the British Museum (Natural History) Geology, supplement 4:1-111.

Elliott, G.F. 1968b. Three new Tethyan Dasycladaceae (calcareous algae). Palaeontology 11:491-497.

Elliott, G.F. 1970. New and little-known Permian and Cretaceous Codiaceae (calcareous algae) from the Middle East. Palaeontology, 13:327-333.

Elliott, G.F. 1971. The nature of Aciculella Pia (calcareous algae). Palaeontology, 14:629-636.

Elliott, G.F. 1972. Lower Palaeozoic green algae from southern Scotland, and their evolutionary significance. Bulletin of the British Museum (Natural History) Geology, 22:357-377.

Emberger, J. 1976. Les algues (Chlorophyceae, Prasinophyceae, Rhodophyceae) du Carbonifère et du Permien. Essai d'un inventaire bibliographique, géographique, stratigraphique. Bulletin de l'Institut de Géologie du Bassin d'Aquitaine, Bordeaux, numéro spécial:1-168.

Endo, R. 1951. Stratigraphical and paleontological studies of the later Paleozoic calcareous algae in Japan. I. Several new species from the Sakamotozawa section, Hikoroichi-mura, Kesen-gun, in the Kitakami Mountainous Land. Transactions and Proceedings Paleontological Society Japan, New Series, 4:121-129.

Endo, R. 1952. Stratigraphical and paleontological studies of the later Paleozoic calcareous algae in Japan. III. A few species from the Maiya section, Maiya-machi, Tome-gun, Miyagiken. Science Reports Saitama University, Series B, 1:23-28.

Endo, R. 1953a. Stratigraphical and paleontological studies of the later Paleozoic calcareous algae in Japan. V. Several species from the Iwaizaki limestone, Motoyoshi-gun, in the Kitakami Mountainous Land. Transactions Japanese Journal Geology Geography, 23:117126.

Endo, R. 1953b. Stratigraphical and paleontological studies of the later Paleozoic calcareous algae in Japan. VI. Several interesting species from the Kwantô Mountainous Land and a new genus from Kinshôzan, Akasaka, Gifu-ken. Science Reports Saitama University, Series $B, 1: 97-104$.

Endo, R. 1954. Stratigraphical and paleontological studies of the later Paleozoic calcareous algae in Japan. IX. Interesting species from the Yayamadake Limestone Subgroup, Kyushu and new species from Sakato-mura, Taga-gun, Ibaraki-ken. Science Reports Saitama University, Series B, 1:217-221.

Endo, R. 1956. Stratigraphical and paleontological studies of the later Paleozoic calcareous algae in Japan. X. Fossil algae from the Kwanto and Kitakami Mountains. The Science Reports of the Saitama University, Series B, 2:221-248. 
Endo, R. 1957. Stratigraphical and paleontological studies of the later Paleozoic calcareous algae in Japan. XI. Fossil algae from the Taishaku district, Horishima-ken, and Kitami-nokuni, Hokkaido. Science Reports Saitama University, Series B, 2:279-305.

Endo, R. 1960. Stratigraphical and paleontological studies of the later Paleozoic calcareous algae in Japan, XV. A restudy of the genus Epimastopora. Science Reports Saitama University, Series B, 3:267-270.

Endo, R. 1961a. Stratigraphical and paleontological studies of the later Paleozoic calcareous algae in Japan, XIV. Fossil algae from the Nyugawa Valley in the Hida Massif. Science Reports Saitama University, Series B, 3:177-207.

Endo, R. 1961b. Phylogenetic relationships among the calcareous algae. Science Reports Saitama University, Series B, Commemorative Volume R. Endo:1-52.

Endo, R. 1961c. Stratigraphical and paleontological studies of the later Paleozoic calcareous algae in Japan, XVI. Fossil algae from the Ominagahama district. Science Reports Saitama University, Series B, Commemorative Volume R. Endo:77-118.

Endo, R. 1961d. Stratigraphical and paleontological studies of the later Paleozoic calcareous algae in Japan, XVII. Fossil algae from the Akiyoshi Limestone Group. Science Reports Saitama University, B, Commemorative Volume R. Endo:119-142.

Endo, R. 1969. Fossil algae from the Khao Phlong Phrab District in Thailand. Geology and Paleontology Southeast Asia, 7:33-85.

Endo, R. and Horiguchi, M. 1957. Stratigraphical and paleontological studies of the later Paleozoic calcareous algae in Japan. XII. Fossil algae from the Fukuji District in the Hida Massif. Japanese Journal Geology and Geography, 28:169-177.

Endo, R. and Kanuma, M. 1954. Stratigraphical and paleontological studies of the later Paleozoic calcareous algae in Japan. VII. Geology of the Mino mountainland and southern part of Hida plateau with description of the algal remains found in those districts. Science Reports Saitama University, Series B, 1:177-205.

Enpu, G., Samankassou, E., Guang C.Q., Zhang Y.L., and Sun B.L. 2007. Paleoecology of Pennsylvanian phylloid algal buildups in south Guizhou, China. Facies, 53:615-623. https:// doi.org/10.1007/s10347-007-0122-4

Fagerstrom, J.A. 1987. The Evolution of Reef Communities. Wiley, New York.

Fagerstrom, J.A. and Weidlich, O. 1999. Strengths and weaknesses of the reef guild concept and quantitative data: Application to the Upper Capitan-Massive community (Permian), Guadalupe Mountains, New Mexico-Texas. Facies, 40:131-156. https://doi.org/10.1007/ bf02537472

Fagerstrom, J.A. and Weidlich, O. 2005. Biologic response to environmental stress in tropical reefs: Lessons from modern Polynesian coralgal atolls and Middle Permian sponge and Shamovella-microbe reefs (Capitan Limestone USA). Facies, 51:501-515. https://doi.org/ 10.1007/s10347-005-0008-2

Fan J., Rigby, J.K., and Qi J.W. 1990. The Permian Reefs of South China and comparisons with the Permian Reef Complex of the Guadalupe Mountains, West Texas and New Mexico. Brigham Young University, Geology Studies, 36:15-55.

Flügel, E. 1966. Algen aus dem Perm der Karnischen Alpen. Carinthia II, 25:3-76.

Flügel, E. 1968. Bericht über fazielle und stratigraphische Untersuchungen im Perm der Karnischen Alpen. Carinthia II, 158/78:38-65.

Flügel, E. 1971a. Palökologische Interpretation des Zottachkopf-Profiles mit Hilfe von Kleinforaminiferen (Oberer Pseudoschwagerinen-Kalk, unteres Perm: Karnische Alpen). Carinthia II, Sonderheft 28:61-96.

Flügel, E. 1971b. Oligoplagia Herak, 1944, eine Gymnocodiaceae. Neues Jahrbuch Geologie Paläontologie Monathefte, Jahrgang 1971, Heft 9:532-536.

Flügel, E. 1974. Fazies-Interpretation der unterpermischen Sedimente in den Karnischen Alpen. Carinthia II, 164/84:43-62.

Flügel, E. 1975. Kalkalgen aus Riffcomplexen der alpin-mediterranen Obertrias. Verhandlungen der Geologischen Bundesanstalt, 1974:297-346.

Flügel, E. 1977. Environmental models for Upper Paleozoic benthic calcareous algal Communities, p. 314-343. In Flügel, E. (ed.), Fossil Algae, Springer-Verlag, BerlinHeidelberg, New York.

Flügel, E. 1979. Paleoecology and microfacies of Permian, Triassic and Jurassic algal communities of platform and reef carbonates from the Alps. Bulletin Centre Recherches Exploration-Production Elf-Aquitaine, 3:569-587. 
Flügel, E. 1980. Die Mikrofazies der Kalke in den Trogkofel-Schichten der Karnischen Alpen, p. 51-100. In Flügel, E. (ed.), Die Trogkofel-Stufe im Unterperm der Karnischen Alpen. Carinthia II, Sonderheft 36, Klagenfurt, Austria.

Flügel, E. 1981. Lower Permian Tubiphytes/Archaeolithoporella buildups in the Southern Alps (Austria and Italy), p. 143-160. In Toomey, F. (ed.), European Fossil Reef Models. SEPM Special Publication, 30, Tulsa, Oklahoma.

Flügel, E. 1987. Reef Mound-Entstehung: Algen-Mounds im Unterperm der Karnischen Alpen. Facies, 17:73-90. https://doi.org/10.1007/bf02536772

Flügel, E. 1990. "Einschnitte" in der Entwicklung permischer Kalkalgen. Mitteilungen Naturwissenschaftlichen Vereinis Steiermark, 120:99-124.

Flügel, E. 2004. Microfacies of Carbonate Rocks, Analysis, Interpretation and Application. Springer, Berlin, Heidelberg, New York.

Flügel, E., Di Stefano, P., and Senowbari-Daryan, B. 1991. Microfacies and depositional structure of allochthonous carbonate base-of-slope deposits: The Late Permian Pietra di Salomone megablock, Sosio Valley (Western Sicily). Facies, 25:147-186. https://doi.org/ $10.1007 / \mathrm{bf0} 2536758$

Flügel, E. and Flügel-Kahler, E. 1980. Algen aus den Kalken der Trogkofel-Schichten der Karnischen Alpen, p. 113-182. In Flügel, E. (ed.), Die Trogkofel-Stufe im Unterperm der Karnischen Alpen. Carinthia II, Sonderheft 36, Klagenfurt, Austria.

Flügel, E. and Flügel-Kahler, E. 1992. Phanerozoic reef evolution: Basic questions and data base. Facies, 26:167-278. https://doi.org/10.1007/bf02539799

Flügel, E., Fohrer, B., Forke, H., Krainer, K., and Samankassou, E. 1997. Excursion B 1, Cyclic sediments and algal mounds in the Upper Paleozoic of the Carnic Alps. Gaea Heidelbergensis, 4:79-100.

Flügel, E., Homann, W., and Tietz, G.-F. 1971. Litho- und Biofazies eines Detailprofils in den Oberen Pseudoschwagerinen-Schichten (Unter-Perm) der Karnischen Alpen. Verhandlungen der Geologischen Bundesanstalt, 1971:10-42.

Flügel, E., Kochansky-Devidé, V., and Ramovš, A. 1984. A Middle Permian calcisponge/algal/ cement reef: Straza near Bled, Slovenia. Facies, 10:179-256. https://doi.org/10.1007/ bf02536692

Flügel, E. and Reinhardt, J. 1989. Uppermost Permian reefs in Skyros (Greece) and Sichuan (China): Implications for the late Permian extinction event. Palaios, 4:502-518. https:// doi.org/10.2307/3514742

Flügel, E., Velledits, F., Senowbari-Daryan, B., and Riedel, P. 1992. Rifforganismenaus "Wettersteinkalken" (Karn?) des Bükk-Gebirges, Ungarn. Geologisch-Paläontologische Mitteilungen Innsbruck, 18(1991/1992):35-62.

Flügel, H. 1963. Algen und Problematica aus dem Perm Süd-Anatoliens und Irans. Sitzungsberichten der Österreichische Akademie der Wissenschaften, MathematischNaturwissenschaftliche Klasse, 172:1-95.

Fohrer, B. and Samankassou, E. 2005. Paleoecological control of ostracode distribution in a Pennsylvanian Auernig cyclothem of the Carnic Alps, Austria. Palaeogeography, Palaeoclimatology, Palaeoecology, 225:317-330. https://doi.org/10.1016/ j.palaeo.2004.02.053

Fontaine, H., Nguyen Duc Tien, and Vachard, D. 1986. Discovery of Permian limestone south of Tara Island in the Calamian Islands, Philippines, p. 161-167. In Fontaine H. (ed.), The Permian of Southeast Asia. CCOP Technical Bulletin, 18, Bangkok and Tokyo.

Fontaine, H., Suteethorn, V., Almeras, Y., Bassoullet, J.P., Beauvais, L., Bernet-Rollande, M.C., Cariou, E., Chennaux, G., Gabilly, J., Nguyen Duc Tien, and Vachard, D. 1988. Late Paleozoic and Mesozoic fossils of West Thailand and their environments. CCOP Technical Bulletin, 20:1-107.

Fontaine, H., Suteethorn, V., and Vachard, D. 1998. Khao Yoi, limestone hill of the Ratburi area, Peninsular Thailand. CCOP Newsletter, 23(3):12-14.

Fontaine, H., Tansuwan, V., and Vachard, D. 1997. Age of limestones associated with gypsum deposits in Northeast and Central Thailand. CCOP Newsletter, 21(4)-22(1):6-7.

Fontaine, H. and Vachard, D. 1984. New paleontological data on the Upper Paleozoic of Sumatra. Mémoire de la Société Géologique de France, Nouvelle Série, 147:49-53.

Fontaine, H. and Vachard, D. 1986. Study of Permian samples collected from Sumatra. United Nations ESCAP, CCOP Technical Bulletin, 18:112-116. 
Forke, H.C. 1994. Biostratigraphie (Fusuliniden; Conodonten) und Mikrofazies im Unterperm (Sakmar) der Karnischen Alpen (Naßfeldgebiet, Österreich) - Bedeutung für die international Korrelation von Fusuliniden- und Conodontenzonierungen. Unpublished Diploma-Thesis, FAU Erlangen-Nürnberg, Erlangen.

Forke, H.C. 1995. Biostratigraphie (Fusuliniden; Conodonten) und Mikrofazies im Unterperm (Sakmar) der Karnischen Alpen (Naßfeldgebiet, Österreich). Jahrbuch der Geologischen Bundesanstalt, 138:207-297.

Forke, H.C. 2000. Late Paleozoic fusulinaceans from the Carnic Alps, p. 199-204. In Piller, W., Daxner-Höck, G., Domning, D.P., Forke, H.C., Harzhauser, M., Hubmann, B., Kollmann, H.A., Kovar-Eder, J., Krystyn, L., Nagel, D., Pervesler, P., Rabeder, G., Roetzl, R., Sanders, D., Summesberger, H. (eds.), Palaeontological Highlights of Austria. Mitteilungen der österreichischen Geologischen Gesellschaft, 92(1999), Vienna.

Forke, H.C. 2002. Biostratigraphic subdivision and correlation of uppermost Carboniferous/ Lower Permian sediments in the southern Alps: Fusulinoidean and conodont faunas from the Carnic Alps (Austria/ltaly), Karavanke Mountains (Slovenia), and Southern Urals (Russia). Facies, 47:201-276. https://doi.org/10.1007/bf02667713

Forke, H.C., Kahler, F., and Krainer, K. 1998. Sedimentology, microfacies and stratigraphic distribution of foraminifers of the Lower "Pseudoschwagerina" Limestone (Rattendorf Group, Late Carboniferous), Carnic Alps (Austria/ltaly). Senckenbergiana lethaea, 78:1-39. https:// doi.org/10.1007/bf03042759

Forke, H.C. and Samankassou, E. 2000. Biostratigraphical correlation of Late Carboniferous (Kasimovian) sections in the Carnic Alps (Austria/ltaly): Integrated paleontological data, facies, and discussion. Facies, 42:177-210. https://doi.org/10.1007/bf02562572

Forke, H.C., Schönlaub, H.P., and Samankassou, E. 2006. Late Paleozoic of the Carnic Alps (Austria/Italy), Field Trip of the SCCS Task Group to establish GSSP's close to the Moscovian/Kasimovian and Kasimovian/Gzhelian boundaries, 21 July-01 August, 2006. Berichte der Geologischen Bundesanstalt, 70:1-57.

Forsythe, G.T.W. 2003. A new synthesis of Permo-Carboniferous phylloid algal reef ecology, p. 171-188. In Ahr, W.M., Harris, P.M., Morgan, W.A., and Somerville, I.D. (eds.), PermoCarboniferous Carbonate Platforms and Reefs. SEPM Special Publication 78 and AAPG Memoir 83, Tulsa.

Forsythe, G.T.W., Wood, R., and Dickson, J.A.D. 2002. Mass spawning in ancient reef communities: Evidence from Late Paleozoic phylloid algae. Palaios, 17:615-621. https:// doi.org/10.1669/0883-1351(2002)017\%3C0615:msiarc\%3E2.0.co;2

Fournié, D. 1967. Les porostromates du Paléozoïque. Etude bibliographique. Bulletin des Centres de Recherche Pau-SNPA, 1:21-41.

Frech, F. 1894. Die Karnischen Alpen. Ein Beitrag zur vergleichenden Gebirgs-Tektonik. Niemeyer Verlag, Halle.

Fritz, A. and Boersma, M. 1983. Fundberichte über Pflanzenfossilien aus Kärnten 1983, Beitrag 5. Carinthia II, 173/93:315-337.

Fritz, A. and Boersma, M. 1984. Fundberichte über Pflanzenfossilien aus Kärnten 1984, Beitrag 9. Carinthia II, 174/94:145-175.

Fritz, A., Boersma, M., and Krainer, K. 1990. Steinkohlenzeitliche Pflanzenfossilien aus Kärnten. Carinthia II, Sonderheft 49:1-189.

Fritz, A. and Krainer, K. 1993. Eine neue Megaflora aus dem Stefan der Kronalpe. Carinthia II, 183/103:485-517.

Fritz, A. and Krainer, K. 1994. Die Megaflora "Garnitzenberg-Südost alpha" aus der AuernigSchichtgruppe der Karnischen Alpen. Carinthia II, 184/104:441-465.

Fritz, A. and Krainer, K. 1995. Die Megafloren Tomritsch-3 und Tomritsch-6 aus den oberkarbonen Auernigschichten der Karnischen Alpen. Carinthia II, 185/105:553-583.

Fritz, A. and Krainer, K. 2004. Pflanzenfossilien aus den Grenzlandbänken der Rattendorfer Alm (Kärnten, Karnische Alpen). Carinthia II, 194/114:445-454.

Fritz, A. and Krainer, K. 2006. Vegetationsgeschichtliche und florenstratigraphische Untersuchungen im Oberkarbon und Unterperm der Ost- und Südalpen (Teil 1). Carinthia II, 196/116:93-120.

Fritz, A. and Krainer, K. 2007. Vegetationsgeschichtliche und florenstratigraphische Untersuchungen im Oberkarbon und Unterperm der Ost- und Südalpen (Teil 2). Carinthia II, 197/117:91-148. 
Gaillot, J. and Vachard, D. 2007. The Khuff Formation (Middle East) and time-equivalents in Turkey and South China: Biostratigraphy from Capitanian to Changhsingian times (Permian), new foraminiferal taxa, and palaeogeographical implications. Coloquios de Paleontología, 57:37-223.

Gallagher, S.J. 1998. Controls on the distribution of calcareous Foraminifera in the Lower Carboniferous of Ireland. Marine Micropaleontology, 34:187-211. https://doi.org/10.1016/ s0377-8398(98)00006-1

Gallagher, S.J. and Somerville, I.D. 1997. Late Dinantian (Lower Carboniferous) platform carbonate stratigraphy of the Buttevant area North Co. Cork, Ireland. Geological Journal, 32:313-335. https://doi.org/10.1002/(sici)1099-1034(199712)32:4\%3C313::aidgj747\%3E3.0.co;2-j

Geitler, L. 1925. Cyanophyceae, p. 1-450. In Pascher, A. (ed.), Die Süsswasser-Flora Deutschlands, Österreichs und der Schweiz, 12, Gustav Fischer, Jena.

Ghazzay-Souli, W., Vachard, D., and Razgallah S. 2015. Carboniferous and Permian biostratigraphy by foraminifers and calcareous algae of Bir Mastoura (BMT-1) and related boreholes of southern Tunisia. Revue de Micropaléontologie, 58:239-265. https://doi.org/ 10.1016/j.revmic.2015.07.004

Glintzboeckel, C. and Rabaté, J. 1964. Microfaunes et Microfaciès du Permo-Carbonifère du Sud-Tunisien. International Sedimentary Petrology Series, E.J. Brill Publisher, Leiden.

Golubic, S. 1973. The relationship between blue-green algae and carbonate deposits, p. 434472. In Carr, N.G. and Whitton, B.A. (eds.), The Biology of Blue-Green Algae. Blackwell, London.

Gomont, M. 1892. Monographie des Oscillariées (Nostocacées homocystées). Annales des Sciences Naturelles, Botanique, Série 7, 15:263-368.

Gortani, M. 1906. Contribuzioni allo studio del Paleozoico Carnico. I. La fauna permocarbonifera del Col di Mezzodi presso Forni Avoltri. Palaeontographica Italica, 12:1-84.

Granier, B. 1986. Algues Chlorophyceae du Jurassique terminal et du Crétacé inférieur en Alicante. Mediterranea, Serie de Estudios Geológicos, 5:5-96.

Granier, B. 2012. The contribution of calcareous green algae to the production of limestones: A review, p. 35-60. In Basso, D. and Granier, B. (eds.), Calcareous Algae and the Global Change: From Identification to Quantification. Geodiversitas, 34, Paris. https://doi.org/ $10.5252 / g 2012 \mathrm{n} 1 \mathrm{a} 3$

Granier, B. and Deloffre, R. 1994. Inventaire critique des algues dasycladales fossiles, Ille partie: Les algues dasycladales du Permien et du Trias. Revue de Paléobiologie, 14:49-84.

Granier, B. and Dias-Brito, D. 2016. On the fossil alga Elianella elegans Pfender \& Basse, 1948, and its so-called lookalikes, with description of Elianella brasiliana n. sp. Revision of the Juliette Pfender Collection. Part 1. Carnets de Géologie, 16(6):213-229.

Granier, B.R.C. and Grgasović, T. 2000. Les algues dasycladales du Permien et du Trias. Nouvelle tentative d'inventaire bibliographique, géographique et stratigraphique. Geologia Croatica, 53:1-197.

Granier, B., Basso, D., and Vachard, D. 2017. Les algues "calcaires" fossiles (Permien-Miocène) du Guatémala (Catalogue critique de la Collection J.H. Johnson. $3^{\mathrm{e}}$ partie). Archives des Sciences, 69:29-54.

Grgasović, T. and Sokač, B. 2007. Stop 2 Sv. Rok - Permian Mizzia-dolomite, p. 23-27. In Grgasović, T. and Vlahović, I. (eds.), Field Trip Guidebook and Abstracts. Hrvastski Geoloski Institut (Croatian Geological Survey). 9th International Symposium on Fossil Algae, Croatia.

Groves, J.R. 1983. Calcareous foraminifers and algae from the type Morrowan (Lower Pennsylvanian) region of northeastern Oklahoma and northwestern Arkansas. Oklahoma Geological Survey Bulletin, 133:1-39.

Groves, J.R. 1986. Calcareous algae and associated microfossils from Mid-Carboniferous rocks in East-Central Idaho. Journal of Paleontology, 60:476-496. https://doi.org/10.1017/ s0022336000022009

Gümbel, C.W. 1872. Die sogenannten Nulliporen (Lithothamnium und Dactylopora) und ihre Betheiligung an der Zusammensetzung der Kalkgesteine. Zweiter Theil: Die Nulliporen des Thierreichs (Dactyloporideae) nebst Nachtrag zum ersten Theile. Abhandlungen der mathematik-physikalischen Klasse der königlichen Bayerischen Akademie der Wissenschaften, 11:231-290. 
Güvenç, T. 1966. Description de quelques espèces d'algues calcaires (Gymnocodiacées et Dasycladacées) du Carbonifère et du Permien des Taurus Occidentaux. Revue de Micropaléontologie, 9:94-103.

Güvenç, T. 1969. Description de deux espèces d'Algues calcaires dans le Permien des Taurus (Turquie). Bulletin de la Société Géologique de France, (7), 11:447-451. https://doi.org/ 10.2113/gssgfbull.s7-xi.3.447

Güvenç, T. 1972. Un nouveau genre d'algue calcaire du Permien Embergerella sp. Türkiye Jeoloji Kurumu Bülteni, 15:21-25.

Güvenç, T. 1975. Discussion des genres de Porostromata Pia 1927 et leurs représentants dans le Carbonifère et le Permien de Turquie. Congress of Earth Sciences, $50^{\text {th }}$ Anniversary Turkish Republic (1973):241-256.

Hance, L., Hou, H., and Vachard, D. (with the collaboration of Devuyst, F.X., Kalvoda, J., Poty, E., and Wu, X.) 2011. Upper Famennian to Visean Foraminifers and Some Carbonate Microproblematica from South China - Hunan, Guangxi and Guizhou. Geological Publishing House, Beijing.

Harris, A.G., Brenckle, P.L., Baesemann, J.F., Krumhardt, A.P., and Gruzlovic, P.D. 1997. Comparison of conodont and calcareous microfossil biostratigraphy and lithostratigraphy of the Lisburne Group (Carboniferous), Sadlerochit Mountains, northeast Brooks Range, Alaska, 195-219. In Dumoulin, J.A. and Gray, J.E. (eds.), Geologic Studies in Alaska by the U.S. Geological Survey, 1995. U.S. Geological Survey Professional Paper 1574, Washington.

Heckel, P.H. and Cocke, J.M. 1979. Phylloid algal mound complexes in outcropping Upper Pennsylvanian rocks of Mid-Continent. American Association of Petroleum Geologists Bulletin, 53:1058-1074. https://doi.org/10.1306/5d25c819-16c1-11d7-8645000102c1865d

Herak, M. 1944. Zur Kenntnis triadischer Kalkschwämme (Sycones). Neues Jahrbuch Mineralogie, Paläontologie und Mineralogie, Abteilung B, 88:107-135.

Herak, M., 1965. Die Kalkalgen in der Stratigraphie der Dinariden. Mitteilungen der Geologischen Gesellschaft in Wien, 58:209-217.

Heritsch, F. 1943. Das Paläozoikum. Stratigraphie der geologischen Formationen der Ostalpen. Erster Band, Gebrueder Borntraeger, Berlin, 1-681 (Faksimile-Nachdruck 2001).

Heritsch, F., Kahler, F., and Metz, K. 1934. Die Schichtfolge von Oberkarbon und Unterperm, p. 163-180. In Heritsch, F. (ed.), Stratigraphie von Oberkarbon und Unterperm in den Karnischen Alpen. Mitteilungen der Geologischen Gesellschaft, 26(1933), Vienna.

Homann, W. 1969. Fazielle Gliederung der unteren Pseudoschwagerinenkalke (Unter-Perm) der Karnischen Alpen. Neues Jahrbuch für Geologie und Paläontologie Monathefte, 1969:265280.

Homann, W. 1972. Unter- und tief-mittelpermische Kalkalgen aus dem Rattendorfer Schichten, dem Trogkofel Kalk und dem Treßdorfer Kalk der Karnischen Alpen (Österreich). Senckenbergiana Lethaea, 53:135-313.

Hottinger, L. 1983. Neritic macroid genesis, an ecological approach, p. 38-55. In Peryt, T. (ed.), Coated Grains. Springer Verlag, Berlin-Heidelberg.

Hughes, G.W. 2005. Saudi Arabian Permo-Triassic biostratigraphy, micropaleontology and palaeoenvironment, p. 91-108. In Powell, A.J. and Riding, J.B. (eds.), Recent Developments in Applied Biostratigraphy. The Micropalaeontological Society, Special Publications, London.

Hughes, G.W. 2010. Calcimicrobe tubules in uppermost Jurassic Arab-A carbonates of Saudi Arabia. GeoArabia, 15:17-26.

Hughes, G.W. 2013. Late Permian to Late Jurassic "microproblematica" of Saudi Arabia: Possible palaeobiological assignments and roles in the palaeoenvironmental reconstructions. GeoArabia, 18:57-92.

Igawa, T. 2003. Microbial contribution to deposition of Upper Carboniferous and Lower Permian seamount-top carbonates, Akiyoshi, Japan. Facies, 48:61-78. https://doi.org/10.1007/ bf02667530

Insalaco, E., Virgone, A., Courme, B., Gaillot, J., Kamali, M., Moallemi, A., Loftpour, M., and Monibi, S. 2006. Upper Dalan Member and Kangan Formation between the Zagros Mountains and Offshore Fars, Iran: Depositional system, biostratigraphy and stratigraphic architecture. GeoArabia, 11:75-176.

Ivanova, R.M. 1988. Izvestkovye vodorosli vizeiskogo yarusa Urala, p. 4-19. In Chuvashov, B.I. and Puchkov, B.N. (eds.), Biostratigrafiya i litologiya verkhnego Paleozoya Urala. Akademiya Nauk SSSR, Uralskoe Otdelnie, Sbornik Nauchnyk Trudov. (In Russian) 
Ivanova, R.M. 1999. Nekotorye izvestovye vodorosli karbona Urala. Paleontologischeskiy Zhurnal, 1966(6):76-79. (In Russian)

Ivanova, R.M. and Bogush, O.I., 1992. Algae as indicators of a biogeographical zonation in the Early Carboniferous of the Urals, Siberia and Northeast Russia. Facies, 27: 235-244. https:// doi.org/10.1007/bf02536815

James, N.P. and Bourque, P.-A. 1992. Reefs and mounds, p. 323-347. In Walker, R.G. and James, N.P. (eds.), Facies Models: Response to Sea Level Change. Geological Association of Canada, Calgary.

Jansa, L.F., Mamet, B., and Roux, A. 1978. Viséan limestones from the Newfoundland Shelf. Canadian Journal of Earth Sciences, 15:1422-1436. https://doi.org/10.1139/e78-149

Jenny-Deshusses, C. 1983. Le Permien de l'Elbourz Central et Oriental (Iran); Stratigraphie et Micropaléontologie (Foraminifères et Algues). Unpublished PhD Thesis, Université de Genève, Geneva.

Johnson, J.H. 1942. Permian lime-secreting algae from the Guadalupe Mountains, New Mexico. Geological Society of America Bulletin, 53:195-226. https://doi.org/10.1130/gsab-53-195

Johnson, J.H. 1946. Lime-secreting algae from the Pennsylvanian and Permian of Kansas. Geological Society of America Bulletin, 57:1087-1120. https://doi.org/10.1130/00167606(1946)57[1087:laftpa]2.0.co;2

Johnson, J.H., 1950. A Permian algal-foraminiferal consortium from West Texas. Journal of Paleontology, 24:61-62.

Johnson, J.H. 1951. Permian calcareous algae from the Apache Mountains, Texas. Journal of Paleontology, 25:21-30.

Johnson, J.H. 1956. Archaeolithophyllum, a new genus of Paleozoic coralline algae. Journal of Paleontology, 30:53-55.

Johnson, J.H. 1963. Pennsylvanian and Permian algae. Quarterly of the Colorado School of Mines, 58:1-211.

Johnson, J.H. 1964. Lower Devonian algae and encrusting foraminifera from New South Wales. Journal of Paleontology, 38:98-108.

Johnson J.H. and Kaska, H.V. 1965. Fossil algae from Guatemala. Professional Contributions of the Colorado School of Mines, 4:1-152.

Johnson, J.H. and Konishi, K. 1956. A review of Mississippian algae, p. 1-84. In Johnson, J.H. and Konishi, K. (eds.), Studies of Mississippian Algae. Quarterly of the Colorado School of Mines, 51(4), Boulder.

Jones, G.LI. and Somerville, I.D. 1996. Irish Dinantian biostratigraphy: Practical applications, p. 371-385. In Stroegen, P., Somerville, I.D., and Jones, G.LI. (eds.), Recent Advances in Carboniferous Geology. Geological Society of London, Special Publications, 107, London.

Kabanov, P., Alekseev, A.S., Baranova, D.V., Gorjunova, R.V., Lazarev, S.S., and Malkov, V.G. 2006. Biotic changes in a eustatic cyclothem: Domodedovo Formation (Moscovian, Carboniferous) of Peski quarries, Moscow region. Paleontological Journal, 40:351-368. https://doi.org/10.1134/s0031030106040010

Kahler, F. 1980. Die Definition der Trogkofel-Stufe (Unterperm, Karnische Alpen). p. 255-258. In Flügel, E. (ed.), Die Trogkofel-Stufe im Unterperm der Karnischen Alpen. Carinthia II, Sonderheft 36, Klagenfurt, Austria.

Kahler, F. 1983a. Fusuliniden aus Karbon und Perm der Karnischen Alpen und der Karawanken. Carinthia II, Sonderheft 41:1-107.

Kahler, F. 1983b. Ein denkbares Standardprofil für die Grenze Oberkarbon/Unterperm im marinen Bereich. Anzeiger der Akademie der Wissenschaften Wien, mathematischnaturwissenschaftliche Klasse, 1983:45-46.

Kahler, F. 1985. Oberkarbon und Unterperm der Karnischen Alpen. Ihre Biostratigraphie mit Hilfe der Fusuliniden. Carinthia II, Sonderheft 42:1-92.

Kahler, F. 1986. Ein Normalprofil der Fusuliniden-Stratigraphie im Oberkarbon und Unterperm der Karnischen Alpen. Carinthia II, 176/96:1-17.

Kahler, F. 1989. Die Fusuliniden, p. 87-295. In Ebner, F. and Kahler, F. (eds.), Catalogus Fossilium Austriae, Heft II/b/1: Foraminifera Palaeozoica. Österreichische Akademie der Wissenschaften, Vienna.

Kahler, F. 1992. Beziehungen der Fusuliniden der Karnischen Alpen zur Paläotethys. Mitteilungen Österreichische Geologische Gesellschaft, 84(1991):309-326. 
Kahler, F. and Kahler, G. 1937. Beiträge zur Kenntnis der Fusuliniden der Ostalpen: die Pseudoschwagerinen der Grenzlandbänke und des oberen Schwagerinenkalkes. Palaeontographica, A, 87:1-34.

Kahler, F. and Kahler, G. 1938. Beobachtungen an Fusuliniden der Karnischen Alpen. A. Über die Einbettung von Pseudoschwagerinen im roten Trogkofelkalk. B. Frasspuren in Fusulinidenschalen. C. Trimorphismus bei Paraschwagerinen. Zentralblatt für Mineralogie, Geologie und Paläontologie, Abteilung B, 4:101-115.

Kahler, F. and Kahler, G. 1980. Fusuliniden aus den Kalken der Trogkofel-Schichten der Karnischen Alpen, p. 183-254. In Flügel, E. (ed.), Die Trogkofel-Stufe im Unterperm der Karnischen Alpen. Carinthia II, 36, Klagenfurt.

Kahler, F. and Krainer, K. 1993. The Schulterkofel Section in the Carnic Alps, Austria: Implications for the Carboniferous-Permian Boundary. Facies, 26:257-276. https://doi.org/ 10.1007/bf02539737

Kahler, F. and Prey, S. 1963. Erläuterungen zur Geologischen Karte des Naßfeld-GartnerkofelGebietes in den Karnischen Alpen. Geologische Bundesanstalt, Wien:1-115.

Karpinsky, A. 1909. Einige problematische Fossilien aus Japan. Verhandlungen Russische Mineralogische Gesellschaft St. Petersburg, 2(46):257-272.

Khodjanyazova, R. and Mamet, B. 2003. Paleozoic calcareous algae from southern Tian Shan, Uzbekistan, Central Asia. Geologica Belgica, 6:97-117.

Khvorova, I.V. 1946. O novom rode vodoroslei iz srednekamennougolnykh otlozhenii Podmoskovnogo basseina. Doklady Akademii Nauk SSSR, 53:737-739, Moscow (English translation from Russian).

Kiessling, W. and Flügel, E. 2000. Late Paleozoic and Late Triassic limestones from North Palawan Blocks (Philippines): Microfacies and paleogeographical implications. Facies, 43:39-78. https://doi.org/10.1007/bf02536984

Kirkland, B.L., Dickson, J.A.D., Wood, R.A., and Land, L.S. 1998. Microbialite and microstratigraphy: The origin of encrustrations in the middle and upper Capitan Formation, Guadalupe Mountains, Texas and New Mexico, U.S.A. Journal of Sedimentary Research, 68:956-969. https://doi.org/10.1306/d42688bf-2b26-11d7-8648000102c1865d

Kirkland, B.L., Moore, C.H. Jr., and Dickson, J.A.D. 1991. Aragonitic Pennsylvanian phylloid algae from New Mexico: The missing link (Abstract). American Association of Petroleum Geologists Bulletin, 75(D3):610.

Kirkland, B.L., Moore, C.H. Jr., and Dickson, J.A.D. 1993. Well-preserved, aragonitic phylloid algae (Eugonophyllum, Udoteacea) from the Pennsylvanian Holder Formation, Sacramento Mountains, New Mexico. Palaios, 8:111-120. https://doi.org/10.2307/3515225

Kitaev, P.M. 1973. K kharateristike kompleksov vodoroslei iz sredne- i verkhnekamennougolnykh otlozhenii zapadnogo sklona srednego Urala, p. 73-83. In Pakhomov, I.V. (ed.), Stratigrafiya i Neftenosnost Karbona Zapadnogo Urala i Priuralya. Permskiy Polytekhnicheskii Instituta, 121, Perm. (In Russian)

Kochansky, V. and Herak, M. 1960. On the Carboniferous and Permian Dasycladaceae of Yugoslavia. Geološki Vjesnik, 13:65-94.

Kochansky-Devidé, V. 1964. Die Fusuliniden und Kalkalgen des jugoslawischen Karbons. Comptes Rendus du $5^{e}$ Congrès de Stratigraphie et de Géologie du Carbonifère, Paris (1963), 2:513-518.

Kochansky-Devidé, V. 1970a. Permski mikrofosili zahodnih Karavank. Geologija, Razprave in Porocila, 13:175-256.

Kochansky-Devidé, V. 1970b. Die Kalkalgen des Karbons vom Velebit-Gebirge (Moskovien und Kasimovien). Palaeontologia Jugoslavica, 10:1-32.

Kochansky-Devidé, V. 1979. Connexia slovenica n. sp., eine leitende Art der TrogkofelAblagerungen (Perm). Palaeontologia Jugoslavica, 23:1-10.

Kochansky-Devidé, V. and Gušić, I. 1971. Evolutions-Tendenzen der Dasycladaceen mit besonderer Berücksichtigung neuer Funde in Jugoslawien. Paläontologische Zeitschrift, 45:82-91.

Kochansky-Devidé, V. and Milanović, M. 1962. Donjopermske fuzulinide i vapnena ke algae podru ja Tare u Crnoj Gori. Geološki Vjesnik, 15:195-228.

Kochansky-Devidé, V. and Ramovš, A. 1978. Das Paläozoikum in Kroatien. Österreichische Akademie Wissenschaften, Schriftenreihe der Erdwissenschaftlichen Kommission, 3:235240. 
Kochansky-Devidé, V. and Slišković, T. 1969. Gornjopermski Mikrofosili Han Orahovice i Suljaca u Bosni s osobitim obzirom na algu Permocalculus fragilis. Geološki vjesnik, 22:105-110.

Kolodka, C., Vennin, E., Vachard, D., Trocme, V., and Goodarzi, M.H. 2012. Timing and progression of the end-Guadalupian crisis in the Fars province (Dalan Formation; Kuh-e Gakhum, Iran) constrained by foraminifers and other carbonate microfossils. Facies, 58:131153. https://doi.org/10.1007/s10347-011-0265-1

Komárek, J., Kaštovský, J., Mareš, J., and Johansen, J.R. 2014. Taxonomic classification of cyanoprokaryotes (cyanobacterial genera) 2014, using a polyphasic approach. Preslia, 86:295-335.

Konishi, K. 1954a. A new species of Gymnocodium and its algal associates in the Permian Kosaki Formation of southern Kyushu. Transactions of Japanese Journal Geology Geography, 25:1-19.

Konishi, K. 1954b. Succodium, a new codiacean genus, and its algal associates in the late Permian Kuma Formation of southern Kyushu, Japan. Tokyo University Faculty Sciences section, 2, 9:225-240.

Konishi, K. and Wray, J.L. 1961. Eugonophyllum, a new Pennsylvanian and Permian algal genus. Journal of Paleontology, 35:659-666.

Kordé, K.B. 1950. K morfologii mutovchatykh sifonei karbona Severnogo Urala. Doklady Akademii Nauk SSSR, 73:569-571, Moscow. (In Russian; French translation, Institut du Pétrole, des Carburants et Lubrifiants 304:1-3)

Kordé, K.B. 1951. Novye rody i vidy izvestkovykh vodoroslei iz kamennougolnykh otlozhenii severnogo Urala. Byulleten Moskovskogo Obshchestva Ispytatelei Prirody, Otdel Geologicheskii, 1:175-182, Moscow. (In Russian)

Kordé, K.B. 1965. Vodorosli, p. 268-284. In Ruzhentsev, V.E. and Sarycheva, T.G. (eds.), Razvitie i smena morskikh organizmov na rubezhe Paleozoya i Mesozoya. Akademiya Nauk SSSR, Trudy Paleontologichekogo Instituta, 108, Moscow. (In Russian)

Kordé, K.B. 1973. Vodorosli Kembriya. Akademiya Nauk SSSR, Trudy Paleontologichekogo Instituta, 139:1-34, Moscow. (In Russian)

Kossovaya, O., Vachard, D., and Izart, A. 2013. Climatic impact on the reef biota in the Cisuralian and Gudalupian (Permian), East European Platform, p. 343-366. In Gasiewicz, A. and Slowakiewicz, M. (eds.), Palaeozoic Climate Cycles: Their Evolutionary and Sedimentological Impact. Geological Society, London, Special Publications, 376. https:// doi.org/10.1144/SP376.19

Köylüoğlu, M. and Altıner, D. 1989. Micropaléontologie (foraminifères) et biostratigraphie du Permien supérieur de la région d'Hakkari (SE Turquie). Revue de Paléobiologie, 8:467-503.

Kozlowski, R. and Kazmierczak, J. 1968. On two Ordovician calcareous algae. Acta Palaeontologica Polonica, 13:325-346.

Krainer, K. 1991. The limestone facies of the Auernig and Carnizza Formations (Auernig Group, Pontebba Supergroup; Carnic Alps). Giornale di Geologia, Serie 3a, 53:161-169.

Krainer, K. 1992. Fazies, Sedimentationsprozesse und Paläogeographie im Karbon der Ost- und Südalpen. Jahrbuch der Geologischen Bundesanstalt, 135:99-193.

Krainer, K. 1993. Das Perm in Kärnten. Carinthia II, 183/103:133-180.

Krainer, K. 1995a. Anthracoporella mounds in the Late Carboniferous Auernig Group, Carnic Alps (Austria). Facies, 32:195-214. https://doi.org/10.1007/bf02537452

Krainer, K. 1995b. Kurzer Bericht über sedimentologisch-stratigraphische Untersuchungen im Jungpaläozoikum (Auernig- und Ratterndorfer Schichtgruppe) der Karnischen Alpen. Jahrbuch der Geologischen Bundesanstalt, 138:687-690.

Krainer, K. 2003. Tubiphytes-Archaeolithoporella buildups associated with carbonate breccias in the basal Trogkofel Group (Carnic Alps, Austria). First Austrian Reef Workshop, Geocenter Vienna May 30-31 (abstract).

Krainer, K. 2007. Late Paleozoic reef mounds of the Carnic Alps (Austria/Italy). Geobios, 40:625-643. https://doi.org/10.1016/j.geobios.2006.12.004

Krainer, K. 2012. High-frequency siliciclastic-carbonate cycles in the Lower Permian Grenzland Formation (Rattendorf Group, Carnic Alps), Austria/ltaly. 29th IAS Meeting on Sedimentology, Schladming, 10-13 Sept. 2012, Conference Book, p.112.

Krainer, K. and Davydov, V. 1998. Facies and biostratigraphy of the Late Carboniferous/Early Permian sedimentary sequence in the Carnic Alps (Austria/Italy), p. 643-662. In CrasquinSoleau, S., Izart, A., Vaslet, D., and DeWever, P. (eds.), Peri-Tethys: Stratigraphic Correlations 2. Geodiversitas, 20(4), Paris. 
Krainer, K., Flügel, E., Vachard, D., and Joachimski, M. 2003b. A close look at Late Carboniferous algal mounds: Schulterkofel, Carnic Alps, Austria. Facies, 49:325-350. https:/ /doi.org/10.1007/s10347-003-0037-7

Krainer, K., Lucas, S.G., and Vachard D. 2007. Wolfcampian Laborcita mound complex, New Mexico, USA, p. 287-290. In Vachard, D. and Vennin, E.: Permian. In Vennin, E., Aretz M. Boulvain, F., and Munnecke, A. (eds.), Facies from Palaeozoic Reefs and Bioaccumulations. Mémoires du Muséum National d'Histoire Naturelle, 195, Publications Scientifiques du Muséum, Paris.

Krainer, K., Lucas, S.G., Vachard, D., and Barrick, J.E. 2015. The Pennsylvanian-Permian section at Robledo Mountain, Doña Ana County, New Mexico, USA, p. 9-41. In Lucas, S.G. and DiMichele, W.A. (eds.), Carboniferous-Permian Transition in the Robledo Mountains, Southern New Mexico. New Mexico Museum of Natural History and Science, Bulletin, 65, Albuquerque, New Mexico.

Krainer, K., Sanders, D. and Schaffhauser, M. 2009. Early Permian shelf margin retreat and carbonate deposition, Zweikofel Massif, Carnic Alps (Austria). Austrian Journal of Earth Sciences, 102:134-148, Vienna. https://doi.org/10.17738/ajes.2015.0026

Krainer, K. and Schaffhauser, M. 2012. The type section of the Lower Permian Zweikofel Formation (Rattendorf Group; Carnic Alps, Austria). Austrian Journal of Earth Sciences, 105:61-79.

Krainer, K. and Vachard, D. 2002. Late Serpukhovian (Namurian A) microfacies and carbonate microfossils from the Carboniferous of Nötsch (Austria). Facies, 46:1-26. https://doi.org/ $10.1007 /$ bf02668070

Krainer, K. and Vachard, D. 2007a. Gzhelian Anthracoporella mounds, Carnic Alps, Austria, p. 283-286. In Vachard, D. and Vennin, E., Permian. In Vennin, E., Aretz, M., Boulvain, F., and Munnecke, A. (eds.), Facies from Palaeozoic Reefs and Bioaccumulations. Mémoires du Muséum National d'Histoire Naturelle, 195, Publications Scientifiques du Muséum, Paris.

Krainer, K. and Vachard, D. 2007b. Sakmarian-Artinskian Shamovella (= Tubiphytes)Archaeolithoporella mounds, Carnic Alps, p. 291-294. In Vachard, D. and Vennin E.: Permian. In Vennin, E., Aretz, M., Boulvain, F., and Munnecke, A. (eds.), Facies from Palaeozoic Reefs and Bioaccumulations. Mémoires du Muséum National d'Histoire Naturelle, 195, Publications Scientifiques du Muséum, Paris.

Krainer, K. and Vachard, D. 2011. The Lower Triassic Werfen Formation of the Karawanken Mountains (southern Austria) and its disaster survivor microfossils, with emphasis on Postcladella n. gen. (Foraminifera, Miliolata, Cornuspirida). Revue de Micropaléontologie, 54:59-85. https://doi.org/10.1016/j.revmic.2008.11.001

Krainer, K., Vachard, D., and Lucas, S.G. 2003a. Microfacies and microfossil assemblages (smaller foraminifers, algae, pseudoalgae) of the Hueco Group and Laborcita Formation (Upper Pennsylvanian-Lower Permian), south-central New Mexico, USA. Rivista Italiana de Stratigrafia e Paleontologia, 109:3-36.

Krainer, K., Vachard, D., and Lucas, S.G. 2009. Facies, microfossils (smaller foraminifers, calcareous algae) and biostratigraphy of the Hueco Group, Dona Aña Mountains, southern New Mexico, USA. Rivista Italiana di Paleontologia e Stratigrafia, 115:3-26.

Krainer, K., Vachard, D., and Lucas, S.G. 2017a. Microfacies, microfossils and biostratigraphy of the Pennsylvanian-Permian Horquilla Formation, New Well Peak, Big Hatchet Mountains (Hidalgo County, southern New Mexico, USA). New Mexico Museum of Natural History and Science, Bulletin, 75:1-163.

Krainer, K., Vachard, D., Lucas, S.G., and Ernst, A. 2017b. Microfacies and sedimentary petrography of Pennsylvanian limestones and sandstones of the Cerros de Amado area, East of Socorro (New Mexico, USA). New Mexico Museum of Natural History and Science, Bulletin, 76:5-43.

Kulik, E.L. 1978. Izvestovye zelenye (sifonovye) vodorosli asselskogo i sakmarskogo yarusov biogernogo massiva Shakhtau (Bashkiriya). Voprosy Mikropaleontologii, 21:182-215. (In Russian)

Kützing, F.T. 1843. Phycologia Generalis oder Anatomie, Physiologie und Systemkunde der Tange. F.A. Brockhaus Verlag, Leipzig.

Lai, X., Wang, W., Wignall, P.B., Bond, D.P.G., Jiang, H., Ali, J.R., John, E.H., and Sun, Y. 2008. Palaeoenvironmental change during the end-Guadalupian (Permian) mass extinction in Sichuan, China. Palaeogeography, Palaeoclimatology, Palaeoecology, 269:78-93. https:// doi.org/10.1016/j.palaeo.2008.08.005 
Lamouroux, J.V.F. 1812. Extrait d'un mémoire sur la classification des Polypiers coralligènes non entièrement pierreux. Nouveau Bulletin Scientifique de la Société Philomathique de Paris, 3:181-188.

Laporte, L.F. 1962. Paleoecology of the Cottonwood Limestone (Permian), northern MidContinent. Geological Society of America Bulletin, 73:521-544. https://doi.org/10.1130/00167606(1962)73[521:potclp]2.0.co;2

Lemoine, M. 1977. Les difficultés de la phylogénie chez les Algues Corallinacées. Bulletin de la Société Géologique de France, (7), 19:1319-1325.

Le Mone, D.V. 1995. The role of Shamovella ("Tubiphytes") in bioherms, p. 135-144. In Garber, R.A. and Lindsay, R.F. (eds.), Wolfcampian-Leonardian Shelf Margin of the Sierra Diablo Seismic Scale Models for Subsurface Exploration. Annual Field Guidebook, West Texas Geological Society, Publication 95-97, Midland.

Lemosquet, Y. and Poncet, J. 1977. Etude de quelques algues calcaires et de quelques microfaciès du Carbonifère du Basin de Béchar (Sahara sud-oranais, Algérie). Bulletin de la Société Géologique de France (7), 19, 2:335-339.

Leven, E.Ya. 1975. Yarusnaya Skala Permskikh Otlozhenii Tetisa. Byulleten Moskovskogo Obshchestva Ispytatelei Prirody, Otdel Geologicheskii, 50:5-21. (In Russian)

Leven, E.Ya., Leonova, T.B., and Dmitriev, V.Yu. 1992. Perm Darvaz-Zaalayskoy Zony Pamira: Fusulinidy, Ammonoidei, Stratigrafiya. Rossiyskaya Akademiya Nauk, Trudy Paleontologicheskogo Instituta, 253:64-109. (In Russian)

Likharev, B.K. 1939 Atlas Rukovodyashchikh Form Iskopaemykh Faun SSSR. Tsentralnyi Nauchno-issledovatelskii Geologo-razvedochnyi Institut 6 (Permskaya sistema):26-46, Leningrad. (In Russian)

Loeblich, A.R. and Tappan, H. 1961. Suprageneric classification of the Rhizopodea. Journal of Paleontology, 35:245-330.

Lucas, S.G., Krainer, K., and Vachard, D. 2015. The Lower Permian Hueco Group, Robledo Mountains, New Mexico (U.S.A.), p. 43-95. In Lucas, S.G. and DiMichele, W.A. (eds.), Carboniferous-Permian Transition in the Robledo Mountains, Southern New Mexico. New Mexico Museum of Natural History and Science Bulletin, 65, Albuquerque, New Mexico.

Lucas S.G., Krainer, K., and Vachard, D. 2017. The Newwellian Substage of the Wolfcampian Stage in the southwestern United States. Permophiles, 64:13-19.

Luchinina, V.A. 1975. Paleoal'gologicheskaya Kharacteristika Rannego Kembriya Sibirskoy Platformy (yugo-vostok). Akademiya Nauk SSSR, Sibirskoe Otdelenie, Trudy Instituta Geologii i Geofiziki, 216:1-97. (In Russian)

Luchinina, V.A. 2009. Renalcis and Epiphyton as different stages in the life cycle of calcareous algae. Paleontological Journal, 43:463-468.

Luchinina, V.A. and Terleev, A.A., 2004. Osobennosti Sostava Dendrolitov v Nizhnekembriiskikh Organogennykh Postroikakh Sibirskoi Platformy. Novosti Paleontologii i Stratigrafii, 6-7:4357. (In Russian)

Lukowiak, M.A., Cramer, K.L., Madzia, D., Hynes, M.G., Norris, R.D., and O'Dea, A. 2018. Historical change in a Caribbean reef sponge community and long-term loss of sponge predators. Marine Ecology Progress Series, 601:127-137.

Luperto Sinni, E. 1979. Cretacicladus minervini n. gen. n. sp., nuova alga (Chlorophyta) del Cenomaniano delle Murge. Studi Geologici, Morfologici e Paleontologici Sulla Regione Pugliese, Adriatica Editrice, Università degli Studi di Bari, 8:1-30.

Lys, M., Stampfli, G., and Jenny, J. 1978. Biostratigraphie du Carbonifère et du Permien de l'Elbourz oriental (Iran du NE). Notes Laboratoire Paléontologie Université Genève, 2:63-99.

Maclntyre, I. 1977. Distribution of submarine cements in a modern Caribbean fringing reef, Galeta Point, Panama. Journal of Sedimentary Petrology, 47:502-516. https://doi.org/ 10.1306/212f71c1-2b24-11d7-8648000102c1865d

Madi, A., Bourque, P.A., and Mamet, B. 1996. Depth-related ecological zonation of a Carboniferous carbonate ramp: Upper Viséan of Béchar Basin, western Algeria. Facies, 35:59-80. https://doi.org/10.1007/bf02536957

Mamet, B.L. 1991. Carboniferous calcareous algae, p. 370-451. In Riding, R. (ed.), Calcareous Algae and Stromatolites. Springer-Verlag, Berlin-Heidelberg.

Mamet, B. 1996. Algues calcaires marines du Paléozoïque supérieur (Equateur, Bolivie). Annales de la Société Géologique de Belgique, 117(1994):155-167.

Mamet, B. 1998. A Late Devonian microfossil with dasyclad algae affinities from northwestern Australia. Alcheringa, 22:21-28. 
Mamet, B.L. 2002. Carboniferous marine algae, lower part of Akiyoshi Limestone Group, Japan, p. 492-528. In Hills, L.V., Henderson, C.M., and Bamber, E.W. (eds.), Carboniferous and Permian of the World. Memoir of Canadian Society of Petroleum Geologists, Calgary.

Mamet, B. 2006. Taxonomy of Viséan marine calcareous algae, Fernie, British Columbia (Canada). Rivista Italiana de Stratigrafia e Paleontologia, 112:323-357.

Mamet, B. and Martínez, C. 1981. Late Viséan microfossils of the Las Caleras Bajas Limestone (Córdoba, Spain). Revista Española de Micropaleontología, 13:105-118.

Mamet, B. and Pinard, S. 1985. Carboniferous algae from the Peratrovich Formation, Southeastern Alaska, p. 91-100. In Toomey, D.F. and Nitecki, M.H. (eds.), Palaeoalgology, Contemporary Research and Applications. Springer Verlag, Berlin-Heidelberg.

Mamet, B. and Préat, A. 1982. Givetianella tsienii, une dasycladale nouvelle du Givétien de la Belgique. Bulletin de la Société Belge de Géologie, 91:209-216.

Mamet, B. and Préat, A. 1992. Algues du Dévonien moyen de Wellin (synclinorium de Dinant, Belgique). Revue de Micropaléontologie, 35:53-75.

Mamet, B. and Préat, A. 2005. Microfaciès d'une lentille récifale à la limite Eifélien/Givétien (Wellin, bord sud du synclinorium de Dinant). Geologica Belgica, 8/3:85-111.

Mamet, B. and Préat, A. 2009. Algues et microfossiles problématiques du Dévonien moyen du "Fondry des Chiens" (bord sud du synclinorium de Dinant, Belgique): Implications paléobathymétriques. Revue de Micropaléontologie, 52:249-263. https://doi.org/10.1016/ j.revmic.2008.06.001

Mamet, B. and Préat, A. 2010. Un atlas d'algues calcaires - Carbonifère, Alaska arctique. Carnets de Géologie, 2010(1):1-60.

Mamet, B. and Préat, A. 2013. Essai de description d'algues nouvelles paléozoïques. Geologica Belgica, 16:35-48.

Mamet, B. and Roux, A. 1975a. Algues dévoniennes et carbonifères de la Téthys occidentale, Troisième partie. Revue de Micropaléontologie, 18:134-187.

Mamet, B. and Roux, A. 1975b. Dasycladales dévoniennes et carbonifères de la Téthys occidentale. Revista Española de Micropaleontología, 7:245-295.

Mamet, B. and Roux, A. 1978. Algues viséennes et namuriennes du Tennessee (Etats-Unis). Revue de Micropaléontologie, 21:68-97.

Mamet, B. and Roux, A. 1983. Algues dévono-carbonifères de l'Australie. Revue de Micropaléontologie, 26:63-131.

Mamet, B. and Roux, A. 1984. Poncetellina nomen novum (algue verte). Revue de Micropaléontologie, 27:138.

Mamet, B. and Rudloff, B. 1972. Algues carbonifères de la partie septentrionale de l'Amérique du Nord. Revue de Micropaléontologie, 15:75-114.

Mamet, B.L. and Stemmerik, L. 2000. Carboniferous algal microflora, Kap Jurgensen and Foldedal Formations, Holm Land and Amdrup Land, eastern North Greenland. Geology of Greenland Survey Bulletin, 187:79-101.

Mamet, B. and Villa, E. 2004. Calcareous marine algae from the Carboniferous (MoscovianGzhelian) of the Cantabrian zone (NW Spain). Revista Española de Paleontología, 19:151190.

Mamet, B. and Zhu, Z.L. 2005. Carboniferous and Permian algal microflora, Tarim Basin (China). Geologica Belgica, 8:3-13.

Mamet, B., Nassichuk, W., and Roux, A. 1979. Algues et stratigraphie du Paléozoïque supérieur de l'Arctique Canadien. Bulletin des Centres de Recherches Exploration Production Elf Aquitaine, 3:669-683.

Mamet, B.L., Roux, A., and Nassichuk, W.W. 1987. Algues carbonifères et permiennes de l'Arctique canadien. Geological Survey of Canada, Bulletin, 342:1-143.

Mamet, B., Roux, A., Lapointe, M., and Gauthier, L. 1992. Algues ordoviciennes et siluriennes de l'île d'Anticosti (Québec, Canada). Revue de Micropaléontologie, 35:211-248.

Maslov, V. (originally translittered as Masloff, W.), 1929. Mikroskopicheskie vodorosli kamennougolnykh Donetskogo basseina. Izvestii Geologicheskogo Komiteta, 48(10):115138. (In Russian)

Maslov, V.P. 1950. Znaschenie bagryanykh vodoroslei dlya stratigrafii SSSR. Doklady Akademii Nauk SSSR, 70:75-78. (In Russian)

Maslov, V.P. 1956a. Onovom iskopaemom semeistve bagryanikh i dvukh novykh rodakh sinezelenykh vodoroslei. Doklady Akademii Nauk SSSR, 107:151-154. (In Russian, French translation CEDP 1381) 
Maslov, V.P. 1956b. Iskopaemye Izvestkovye Vodorosli SSSR. Akademiya Nauk SSSR, Trudy Instituta Geologicheskikh Nauk, 160:1-301. (In Russian; French translation BRGM no 3517)

Maslov, V.P. 1963. Tip Chlorophyta; zelenye vodorosli, p. 198-223. In Orlov, Yu.A. (ed.), Osnovy Paleontologii, 14, Moscow. (In Russian)

Maslov, V.P. 1973. Atlas porodoobrazufschchikh organizmov (izvestkovykh i kremnevykh). Izdatelstvo "Nauka", Moscow. (In Russian)

Maslov, V.P., Naumova, S.M., and Kordé, K.B. 1963. Chlorophyta, p. 198-223. In Orlov, Yu.A. (ed.), Osnovy Paleontologii SSSR, 14, Moscow. (In Russian; French translation by M. Szyszman, BRGM, 4933, 52 p.)

Massa, D. and Vachard, D. 1979. Le Carbonifère de Lybie Occidentale: biostratigraphie et micropaléontologie; position dans le domaine téthysien d'Afrique du Nord. Revue Institut Français Pétrole, 34:3-65.

Massari, F., Pesavento, M., and Venturini, C. 1991. The Permian-Carboniferous cyclothemes of the Pramollo Basin sequence (Carnic Alps). Giornale di Geologia, 53:171-185.

Massari, F. and Venturini, C. 1990. The significance of the Auernig Group cyclicity. In Venturini C. (ed.), Field Workshop on Carboniferous to Permian sequence of the Pramollo-Nassfeld Basin (Carnic Alps), 81-89, Arti Grafiche Friulane, Udine.

Mazzullo, S.J. and Cys, J.M. 1979. Marine aragonite sea-floor growth and cements in Permian phylloid algal mounds, Sacramento Mountains, New Mexico. Journal of Sedimentary Petrology, 49:917-936. https://doi.org/10.1306/212f7879-2b24-11d7-8648000102c1865d

Mazzullo, S.J. and Cys, J.M. 1983. Unusual algal-crystalline carbonate coated grains from the Capitan Reef (Permian, Guadalupian, New Mexico, USA), p. 599-608. In Peryt, T.M. (ed.), Coated Grains. Springer Publisher, Berlin, Heidelberg, New York, Tokyo.

Merz, M.U.E. 1992. The biology of carbonate precipitation by cyanobacteria. Facies, 6:81-102. https://doi.org/10.1007/bf02539795

Miklukho-Maklay, A.D. 1958. O yarusnom delenii morskikh permskikh otlozhenii yuzhnikh rayonov SSSR. Doklady Akademii Nauk SSSR, 120:175-178. (In Russian)

Milanović, M. 1965. Salopekiella, a new genus of the Dasycladaceae family from the Permian sediments of the Velebit range. Acta Geologica Jugoslavica, 35:373-382.

Milanović, M. 1982. Carboniferous microfossil associations from Gorski Kotar, Hrvatsko Zagorje and Banija. Palaeontologia Jugoslavica, 28:1-34.

Mohtat Aghai, P. and Vachard, D. 2005. Permian foraminiferal assemblages of the Hambast region (central Iran) and their extinctions. Revista Española de Micropaleontología, 37:205227.

Moix, P., Beccaletto, L., Masset, O., Kozur, H.W., Dumitrica, P., Vachard, D., Martini, R., and Stampfli, G.M. 2011. Geology and correlation of the Mersin Mélanges, southern Turkey. Turkish Journal of Earth Sciences, 20:57-98.

Moix, P., Vachard, D., Allibon, J., Martini, R., Wernli, R., Kozur, H.W., and Stampfli, G.M. 2013. Palaeotethyan, Neotethyan and Hu Lu-Pindos Series in the Lycian Nappes (SW Turkey): Geodynamical implications, p. 401-444. In Tanner, L.H., Spielmann, J.A., and Lucas, S.G. (eds.), The Triassic System. New Mexico Museum of Natural History and Science, Bulletin, 61, Albuquerque, New Mexico.

Montenat, C., de Lapparent, A.F., Lys, M., Termier, G., Termier, H., and Vachard, D. 1977. La transgression permienne et son substrat éocambrien dans le Jebel Akhdar, montagnes d'Oman, Péninsule Arabique. Annales de la Société Géologique du Nord, 96/3(1976):239_ 258.

Moore, C.H. 2001. Carbonate Reservoirs; Porosity Evolution and Diagenesis in a Sequence Stratigraphic Framework. Developments in Sedimentology, 55, Elsevier, Amsterdam, London, New York, Oxford, Paris, Shannon, Tokyo.

Moshier, O. and Kirkland, B. 1993. Identification and diagenesis of a phylloid alga: Archaeolithophyllum from the Pennsylvanian Providence Limestone, Western Kentucky. Journal of Sedimentary Petrology, 63:1032-1041. https://doi.org/10.1306/d4267c8a-2b26$11 \mathrm{~d} 7-8648000102 \mathrm{c} 1865 \mathrm{~d}$

Moshier, O. and Kirkland, B. 1994. Identification and diagenesis of a phylloid alga: Archaeolithophyllum from the Pennsylvanian Providence Limestone, Western Kentucky Reply. Journal of Sedimentary Petrology, A63:925-926. https://doi.org/10.1306/d4267f1e2b26-11d7-8648000102c1865d

Mu, X.N. 1981. Upper Permian calcareous algae from western Guizhou. Acta Palaeontologica Sinica, 20:33-48. (In Chinese) 
Mu, X.N. 1982. Some calcareous algae from Xizang, p. 205-238. In The Series of the Scientific Expedition to the Qinghai-Xizang Plateau. Paleontology of Xizang, Book V, Science Press, Beijing. (In Chinese)

Mu, X.N. 1985. Late Carboniferous calcareous algae, p. 142-146.Geology and Paleontology of Mount Tomur in the Tianshan Mountains. (In Chinese with English abstract) http:// www.marinespecies.org/foraminifera/aphia. $p h p ? p=$ sourcedetails\&id=291250

Mu, X.N. and Riding, R. 1983. Silicified gymnocodiacean algae from the Permian of Nanjing, China. Palaeontology, 26:261-276.

Nestell, G.P., Nestell, M.K., Ellwood, B.B., Wardlaw, B.R., Basu, A.R., Ghosh, N., Lan Luu Thi Phuong, Rowe, H.D. Hunt, A., Tomkin, J.H., and Ratcliffe, K.T. 2015. High influx of carbon in walls of agglutinated foraminifers during the Permian-Triassic transition in global oceans. International Geology Review, 57:411-427 https://doi.org/10.1080/00206814.2015.1010610

Nguyen Duc Tien 1979. Etude Micropaléontologique (Foraminifères) de Matériaux du Permien du Cambodge. Unpublished PhD Thesis, Université Paris-Sud, Orsay.

Nguyen Duc Tien 1986a. Foraminifera and algae from the Permian of Kampuchea, p. 116-137. In Fontaine H. with contributions of Nguyen Duc Tien, D. Vachard, C. Vozenin-Serra. (eds.), The Permian of Southeast Asia, Appendix 2. CCOP Technical Bulletin, 18, Bangkok and Tokyo.

Nguyen Duc Tien 1986b. Foraminifera and algae from the Permian of Guguk Bulat and Silungkang, Sumatra, p. 138-147. In Fontaine H. with contributions of Nguyen Duc Tien, D. Vachard, C. Vozenin-Serra. (eds.), The Permian of Southeast Asia, Appendix 2. CCOP Technical Bulletin, 18, Bangkok and Tokyo.

Nguyen Duc Tien 1989. Lower Permian Foraminifera of Sumatra, p. 71-94. In Fontaine, H. and Gafoer, S. (eds.), The Pre-Tertiary Fossils of Sumatra and Their Environments. CCOP Technical Publication, 19, Bangkok and Tokyo.

Nguyen Lan Tu 1970. Some Permian fossil algae from Viet-Nam, Cambodia and Laos. Archives Géologiques du Viêt-Nam, 13(2):1-42.

Nicholson, H.A. 1888. Certain anomalous organisms which are concerned in the formation of some of the Paleozoic limestones. Geological Magazine, 5:15-24.

Nicholson, H.A. and Etheridge, R. Jr 1878. A monograph of the Silurian fossils of the Girvan District of Ayrshire with special reference to those contained in the "Gray Collection". Scotland Geological Survey Memoir, 1(1):1-135.

Noé, S. 2003. Spätstadium einer sterbenden Karbonatplattform: Schelfrand- und AussenschelfEntwicklung der Tansill-Formation (Permian Reef Complex, New Mexico, USA). Kölner Forum für Geologie und Paläontologie, 11-3:1-254.

Okla, S. 1992. Permian algae and algal microfacies from Unayzah, Quassim district, Saudi Arabia. Facies, 27:217-224. https://doi.org/10.1007/bf02536813

Pajić, V. and Filipović, I. 1995. Foraminifers and algae, p. 92-96. In Filipović, I. (ed.), Karbon Severozapadne Srbije (The Carboniferous of northwestern Serbia). Rasprave geoloskog zavoda "Gemini", 25, Belgrade.

Pal, A.K. 1976. The algal family Dasycladaceae, its taxonomy and evolution. Proceedings 6th Indian Colloquium of Micropaleontology and Stratigraphy, 154-181.

Pantić, S. 1970. Lithostratigraphy and micropaleontology of the Middle and Upper Permian of Western Serbia. Vesnik Zavoda za Geolološka i Geofizička Istraživanja, A, 27:201-215.

Pantić, S. 1972. Aeolisaccus amplimuralis n. sp. i Aeolisaccus gracilis n. sp. iz srednjeg Trijasa jugoistocnih Dinarida. Bulletin du Muséum d'Histoire Naturelle, Belgrade, series A, 27:211221.

Parvizi, T., Rashidi, K., and Vachard, D. 2013. Middle Permian calcareous algae and microproblematica (Dalan Formation, Dena Mountain, High Zagros, SW Iran). Facies, 59:149-177. https://doi.org/10.1007/s10347-012-0357-6

Pascher, A. 1914. Über Flagellaten und Algen. Berichte der Deutschen Botanischen Gesellschaft, 32:136-160.

Pascher, A. 1931. Systematische Übersicht über die mit Flagellaten in Zusammenhang stehenden Algenreihen und Versuch einer Einreihung dieser Algenstämme in die Stämme des Pflanzenreiches. Beihefte zum Botanischer Zentralblatt, 48:317-332.

Pentecost, A. and Riding, R., 1986. Calcification in cyanobacteria. p. 73-90. In Leadbeather B.S.C. and Riding R. (eds.), Biomineralization in Lower Plants and Animals. The Systematic Association, Special Volume 30, London. 
Perret, M.F. and Vachard, D. 1977. Algues et pseudo-algues des calcaires serpoukhoviens d'Ardengost (Hautes-Pyrénées). Annales de Paléontologie (Invertébrés), 63:85-156.

Perret, M.F., Vachard, D., Aguirre, P., and Crasquin-Soleau, S. 1994. Micropaléontologie des calcaires épibathyaux à Globochaete (algue problématique) du Carbonifère des Pyrénées. Geobios, 27:659-675. https://doi.org/10.1016/s0016-6995(94)80053-7

Perrin, C. 1992. Signification écologique des foraminifères acervulinidés et leur rôle dans la formation des facies récifaux et organogènes depuis le Paléocène. Geobios, 25:725-751. https://doi.org/10.1016/s0016-6995(92)80054-h

Peterhans, E. 1929. Les algues jurassiques Solenoporella et Pseudochaetetes. Bulletin de la Société Géologique de France, Série 4, 29:3-10.

Peterson, J.A. and Hite, R.J. 1969. Pennsylvanian evaporite-carbonate cycles and their relation to petroleum occurrence, southern Rocky Mountains. American Association of Petroleum Geologists Bulletin, 53:884-908. https://doi.org/10.1306/5d25c807-16c1-11d78645000102c1865d

Petryk, A.A. and Mamet, B. 1972. Lower Carboniferous algal microflora, southwestern Alberta. Canadian Journal of Earth Sciences, 9:767-802. https://doi.org/10.1139/e72-064

Pfender, J. and Basse, E. 1948. Elianella nov. gen. elegans nov. sp., organisme constructeur de calcaires typiquement développé dans le Paléocène du SW malgache. Bulletin de la Société Géologique de France, (5), 17:275-278.

Pia, J. von 1912. Neue Studien über die triadischen Siphoneae verticillatae. Beiträge zur Paläontologie und Geologie Österreich-Ungarns und des Orients, Wien und Leipzig, 25:2581.

Pia, J. von 1920. Die Siphoneae verticillatae vom Karbon bis zur Kreide. Abhandlungen der Zoologisch-Botanischen Gesellschaft in Wien, 11:1-263 (French translation: Editions Technip, Paris).

Pia, J. von 1922. Einige Ergebnisse neuerer Untersuchungen über die Geschichte der Siphoneae verticillatae. Zeitschrift für Induktive Abstammungs- und Vererbungslehre, 30:6398.

Pia, J. von 1927. Thallophyta, p. 31-136. In Hirmer, M. (ed.), Handbuch der Paläobotanik. Band: Thallophyta, Bryophyta, Pteridophyta, 1. Verlag R. Oldenburg, München-Berlin.

Pia, J. von 1930. Upper Triassic fossils from the Burmo-Siamese frontier. A new Dasycladacea, Holosporella siamensis nov. gen., nov. sp., with a description of the allied genus Aciculella Pia. Recueils of Geological Survey of India, 63:177-181.

Pia, J. von 1937. Die wichtigsten Kalkalgen des Jungpaläozoikums und ihre geologische Bedeutung. Compte Rendu du 2e Congrès pour l'Avancement des Etudes de Stratigraphie du Carbonifère, Heerlen 1935, 2:765-856.

Pille, L. 2008. Foraminifères et Algues Calcaires du Mississippien Supérieur (Viséen supérieurSerpukhovien): Rôles Biostratigraphique, Paléoécologique et Paléogéographique aux échelles Locale, Régionale et Mondiale. Unpublished PhD thesis, Université Lille 1, Villeneuve d'Ascq.

Pingitore, N.E. 1994. Identification and diagenesis of a phylloid alga; Archaeolithophyllum from the Pennsylvanian Providence Limestone, western Kentucky; discussion. Journal of Sedimentary Research, 64:923-924. https://doi.org/10.1306/d4267f19-2b26-11d78648000102c1865d

Plummer, H.J. 1930. Calcareous foraminifera in the Brownwood shale near Bridgeport, Texas. Bulletin University of Texas, 3019:5-21.

Pokorny, V. 1951. The Middle Devonian foraminifera of Celechovice, Czechoslovakia. Vestnik Kraslovske Ceske Spolecnosti Nauk, Trida matematicko-prirodovedecka, 9:1-29.

Poncet, J. 1971. Pseudochaetetes devoniensis (Johnson) et Solenopora erecta n. sp., Solenoporaceae des calcaires dévoniens de l'horizon récifal de Baubigny (Cotentin). Revue de Micropaléontologie, 14:91-95.

Poncet, J. 1986. Les algues calcaires du Carbonifère moyen du bassin de Béchar (Sahara algérien). Revue de Micropaléontologie, 29:187-197.

Poncet, J. 1989. Présence du genre Halimeda Lamouroux, 1812 (Algue verte calcaire) dans le Permien supérieur du Sud Tunisien. Revue de Micropaléontologie, 32:40-44.

Poty, E., Devuyst, F.X., and Hance, L. 2006. Upper Devonian and Mississippian foraminiferal and rugose coral zonations of Belgium and Northern France, a tool for Eurasian correlations. Geological Magazine, 143:829-857. https://doi.org/10.1017/s0016756806002457 
Pratt, B.R. 1995. The origin, biota and evolution of deep-water mud-mounds, p. 49-123. In Monty, C.L.V., Bosence, D.W.J., Bridges, P.H., and Pratt, B.R. (eds.), Carbonate Mudmounds. Special Publications of International Association of Sedimentologists, 23, Oxford.

Praturlon, A. 1963. Dasycladaceae from the Upper Permian of the Dolomites (Italy). Geologica Romana, 2:119-150.

Pray, L.C. and Wray, J.L. 1963. Porous algal facies (Pennsylvanian), Honaker Trail, San Juan Canyon, Utah, p. 204-234. In Bass R.O. and Sharps, S.L. (eds.), Shelf Carbonates, Paradox Basin. Four Corners Geological Society Symposium, Fourth Field Conference Guidebook, Durango, Colorado.

Proust, J.-N., Vennin, E., Vachard, D., Boisseau, T., Chuvashov, B., Ivanova, R., Masse, P., and Maslo, A. 1996. Etude sédimentologique et biostratigraphique du stratotype du Bashkirien (Oural du Sud, Russie). Bulletin des Centres de Recherche et d'Exploration-Production ElfAquitaine, 20:341-365.

Rácz, L.G. 1966a. Carboniferous calcareous algae and their associations in the San Emiliano and Lois-Ciguera Formations (Province of León, NW Spain). Leidse Geologische Mededelingen, 31(1964):1-112.

Rácz, L.G. 1966b. Late Palaeozoic calcareous algae in the Pisuerga Basin (N.-Palencia, Spain). Leidse Geologische Mededelingen, 31(1964):241-260.

Ramovš, A. 1971. Biostratigraphische Charakteristik der Oberkarbon-Schichten in den Südkarawanken, N.W. Jugoslawien. Comptes Rendus du 6ème Congrès International de Stratigraphie et Géologie du Carbonifère, Sheffield, 4:1387-1394.

Ramovš, A. and Kochansky-Devidé, V. 1965. Razvoj mlajsega Paleozoika v okolici Ortneka na Dolenjskem (Die Entwicklung des Jungpaläozoikums in der Umgebung von Ortnek in Unterkrain). Slovenska Akademia Znanosti Umetnosti (Ljubljana) Class 4, Historia Naturalis Medicina Razprave, Dissertation, 8:323-416.

Ramovš, A. and Kochansky-Devidé, V. 1981. Carboniferous and Permian beds at Log in the Julian Alps. Geologija, 24:91-107.

Rao, L.R. and Pia, J. von 1936. Fossil algae from the uppermost Cretaceous beds (the Niniyur Group) of the Trichinopoly district, S. India. Memoirs of the Geological Survey of India, Palaeontologia Indica, Calcuta (New Series), 21:1-49.

Rauzer-Chernousova, D.M. and Korolyuk, I.K. 1981. K morfologii i sistematike pozdnemoskovskikh sifonovykh vodoroslei yuzhnogo urala i ob ikh roli v porodoobrazovanikh. Voprosy Mikropaleontologii, 24:157-170. (In Russian)

Razgallah, S. and Vachard, D. 1991. Systématique et biosédimentologie des algues constructrices permiennes Tubiphytes et Archaeolithoporella, suivant l'exemple du Djebel Tebaga (Murghabien de Tunisie). Palaeontographica, B, 221:171-205.

Reid, P.R. 1986. Discovery of Triassic phylloid algae: possible links with the Paleozoic. Canadian Journal of Earth Sciences, 23: 2068-2071. https://doi.org/10.1139/e86-191

Reitlinger, E.A. 1959. Atlas Mikroskopicheskikh Organnichaskikh Ostatkov i Problematiki Drevnikh Tolshch Sibiri. Akademiya Nauk SSSR, Trudy Geologicheskogo Instituta, 25:3-59. (In Russian)

Rezak, R. 1959. Permian algae from Saudi Arabia. Journal of Paleontology, 33:531-539.

Rich, M. 1974. Upper Mississippian (Carboniferous) calcareous algae from northeastern Alabama, South-Central Tennessee and Northwestern Georgia. Journal of Paleontology, 48:360-374.

Riding, R. 1975. Girvanella and other algae as depth indicators. Lethaia, 8:173-179. https:// doi.org/10.1111/j.1502-3931.1975.tb01310.x

Riding, R. 1991. Classification of microbial carbonates, p. 23-51. In Riding, R. (ed.), Calcareous Algae and Stromatolites. Springer-Verlag, Berlin, Heidelberg

Riding, R. 2008. Abiogenic, microbial and hybrid authigenic carbonate crusts: Components of Precambrian stromatolites. Geologica Croatica, 61:73-103.

Riding, R. and Brasier, M. 1975. Earliest calcareous foraminifera. Nature, 257(5523):208-210. https://doi.org/10.1038/257208a0

Riding, R. and Guo, L. 1991. Permian marine calcareous algae, p. 452-480. In Riding, R. (ed.), Calcareous Algae and Stromatolites. Springer Verlag, Berlin. 
Rigaud, S. 2012. The Late Triassic Martin Bridge Carbonate Platform (Wallowa Terrane, NW U.S.A.): Sedimentology, Biostratigraphy, and Contribution to the Understanding of Aragonitic and Microgranular Foraminifers. Unpublished PhD Thesis, Université de Genève, 4439, Geneva.

Roux, A. 1979. Révision du genre Epimastopora "Pia, 1922" (Dasycladaceae). Bulletin Centres de Recherches et d'Exploration-Production Elf-Aquitaine, 3(2):803-810.

Roux, A. 1985. Introduction à l'étude des algues fossiles paléozoïques (de la bactérie à la tectonique des plaques). Bulletin Centre de Recherches et d'Exploration-Production ElfAquitaine, 9:465-699.

Roux, A. 1991. Révision des Gymnocodiaceae (algues rouges, Permien-Crétacé): Taxonomie, biostratigraphie, paléobiogéographie, 2e partie. Revue de Micropaléontologie, 34:136-173.

Roux, A. and Deloffre, R. 1990. Révision des Gymnocodiaceae (algues rouges PermienCrétacé). Taxonomie, biostratigraphie, paléobiogéographie, 1re partie: Généralités sur la famille. Revue de Micropaléontologie, 33:123-137.

Roylance, M.H. 1990. Depositional and diagenetic history of a Pennsylvanian algal-mound complex: Bug and Papoose Canyon fields, Paradox Basin, Utah and Colorado. American Association of Petroleum Geologists Bulletin, 78:1820-1842. https://doi.org/10.1306/ 0c9b241b-1710-11d7-8645000102c1865d

Sachs, J. von 1874. Lehrbuch der Botanik. $4^{\text {th }}$ Edition, Verlag Wilhem Engelmann, Leipzig.

Said, I. 2005. Estudio de los Corales Rugosos con Disepimientos del Mississippiense del NE de la Meseta Marroquí (sectores de Adarouch y Agourai). Unpublished PhD Thesis, Universidad Complutense de Madrid, Facultad de Ciencias Geológicas, Madrid, Spain.

Saltovskaya, V.D. 1984a. Foraminifery ili vodorosli (?) (k morfologii i sistematike semitsva Renalcidae Riding et Brasier, 1975), p. 7-15. In Alekseev, R.E. and Betekhtina O.A. (eds.), Problematica paleozoya i Mezozoya. Akademiya Nauk SSSR, Sibirskoe Otdelnie, Institut Geologii i Geofiziki, Trudy, 597, Novosibirsk. (In Russian)

Saltovskaya, V.D. 1984b. Nekotorye izvestkovye vodorosli Paleozoya Tadzhikistana, p. 141160. In Dzhalilov, M.R. (ed.), Novye Vidy Iskopaemoi Fauny i Flory Tadzhikistana. Akademiya Nauk Tadzhiskoi SSR, Institut Geologii, Dushambe. (In Russian)

Samankassou, E. 1997a. Palaeontological response to sea-level change: Distribution of fauna and flora in cyclothems from the Lower Pseudoschwagerina Limestone (latest Carboniferous, Carnic Alps, Austria). Geobios, 30:785-796. https://doi.org/10.1016/s00166995(97)80178-7

Samankassou, E. 1997b. Muster und Kontrollfaktoren der Zyklischen Sedimentation im Jungpaläozoikum (Oberkarbon-Unterperm) der Karnischen Alpen, Österreich: Eine Integrierte Untersuchung. Unpublished PhD Thesis, University of Erlangen-Nürnberg, Erlangen, Germany.

Samankassou, E. 1998. Skeletal framework mounds of dasycladalean alga Anthracoporella, Upper Paleozoic, Carnic Alps, Austria. Palaois, 13:297-300. https://doi.org/10.2307/3515452

Samankassou, E. 1999. Drowning of algal mounds: Records from the Upper Carboniferous Lower Pseudoschwagerina Limestone, Carnic Alps, Austria. Sedimentary Geology, 127: 209-220. https://doi.org/10.1016/s0037-0738(99)00052-4

Samankassou, E. 2002. Cool-water carbonates in a paleoequatorial shallow-water environment: The paradox of the Auernig cyclic sediments (Upper Pennsylvanian, Carnic Alps, AustriaItaly) and its implications. Geology, 30:655-658. https://doi.org/10.1130/00917613(2002)030\%3C0655:cwciap\%3E2.0.co;2

Samankassou, E. 2003. Upper Carboniferous-Lower Permian buildups of the Carnic Alps, Austria-Italy, p. 201-217. In Ahr, W.M., Harris, P.M., Morgan, W.A., and Somerville, I.D. (eds.), Permo-Carboniferous Carbonate Platforms and Reefs. SEPM Special Publication, 78 and AAPG Memoir, 83, Tulsa, Oklahoma.

Samankassou, E. and West, R.W. 2002. Construction versus accumulation in phylloid algal mounds: An example of a small constucted mound in the Pennsylvanian of Kansas, USA. Palaeogeography, Palaeoclimatology, Palaeoecology, 185:379-389. https://doi.org/10.1016/ s0031-0182(02)00425-x

Samankassou, E. and West, R.W. 2003. Constructional and accumulation modes of fabrics in selected Pennsylvanian algal-dominated buildups in Eastern Kansas, Midcontinent, U.S.A., p. 219-237. In Ahr, W.M., Harris, P.M., Morgan, W.A., and Somerville, I.D. (eds.), PermoCarboniferous Carbonate Platforms and Reefs. SEPM Special Publication, 78 and AAPG Memoir, 83, Tulsa, Oklahoma. 
Samankassou, E., von Allmen, K., and Bahamonde, J.R. 2013. Growth dynamics of Pennsylvanian carbonate mounds from a mixed terrigenous-carbonate ramp in the Puebla de Lillo area, Cantabrian Mountains, northern Spain. Journal of Sedimentary Research, 83:1100-1113. https://doi.org/10.2110/jsr.2013.84

Sanders, D. and Krainer, K. 2005. Taphonomy of Early Permian benthic assemblages (Carnic Alps, Austria): carbonate dissolution versus biogenic carbonate precipitation. Facies, 51:522-540. https://doi.org/10.1007/s10347-005-0065-6

Sano, H. and Kanmera, K. 1996. Microbial controls on Panthalassan Carboniferous-Permian oceanic buiups, Japan. Facies, 34:239-256. https://doi.org/10.1007/bf02546167

Sartorio D. and Venturini, S. 1988. Southern Tethys Biofacies. AGIP S.p.A., San Donato Milanese.

Săsăran, E., Bucur, I.I., Pleş, G., and Riding, R. 2014. Late Jurassic Epiphyton-like cyanobacteria: Indicators of long-term episodic variation in marine bioinduced microbial calcification? Palaeogeography, Palaeoclimatology, Palaeoecology, 401:122-131. https:// doi.org/10.1016/j.palaeo.2014.02.026

Schaffhauser, M. 2013. The Trogkofel Formation: Sedimentology and Diagenesis of a Rimmed Carbonate Shelf Margin in the Lower Permian of the Carnic Alps (Austria/ltaly). Unpublished Ph.D. Thesis, Faculty of Geo- and Atmospheric Sciences, Innsbruck Universität, Innsbruck.

Schaffhauser, M., Krainer, K., and Sanders, D. 2010. The Zottachkopf Formation: A new formation in the Lower Permian Rattendorf Group (Carnic Alps, Austria). Pangeo 2010, Abstracts, Journal of Alpine Geology, 52:218-219.

Schaffhauser, M., Krainer, K., and Sanders, D. 2015. Early Permian carbonate shelf margin deposits: The type section of the Trogkofel Formation (Artinskian/Kungurian), Carnic Alps, Austria/Italy. Austrian Journal of Earth Sciences, 108:277-301. https://doi.org/10.17738/ ajes.2015.0026

Schaffner, J.H. 1922. The classification of plants, XII. The Ohio Journal of Science, 22 (5):129139. http://hdl.handle.net/1811/2166

Schlagintweit, F. 2010. Gosavisiphon gen. nov. based on Halimeda paucimedullaris Schlagintweit \& Ebli, 1998: A remarkable macroalga (Udoteaceae?) from the Late Cretaceous of the Northern Calcareous Alps, (Austria and Germany), with affinities to Late Palaeozoic and Late Triassic phylloids. Geologia Croatica, 63:27-53.

Schönlaub, H.P. 1987. Geologische Karte der Republik Österreich 1: 50 000, Blatt 198 Weißbriach. Geologische Bundesanstalt, Vienna.

Schönlaub, H.P. and Forke H.C. 2007. Die post-variszische Schichtfolge der Karnischen Alpen Erläuterungen zur Geologischen Karte des Jungpaläozoikums der Karnischen Alpen 1: 12500. Abhandlungen der Geologischen Bundesanstalt, 61:3-157.

Schönlaub, H.P., Forke, H.C., Lotter, M., and Moser, M. 2007. Geologische Karte 1: 12500 des Jungpaläozoikums der Karnischen Alpen. Erläuternde Texte. Abhandlungen der Geologischen Bundesanstalt, 61:1-173.

Schubert, R.J. 1907. Vorlaufige Mitteilung über Foraminiferen und Kalkalgen aus demDalmatischen Karbon. Verhandlungen der kaiserlich-königlichen Geologischen Reichsanstalt, 1907, 8:211-214.

Schubert, R.J. 1908. Zur Geologie des österreichischen Velebit. Jahrbuch der Geologischen Reichanstalt, 58:345-386.

Sebbar, A. 2000. Dynamique des Microfossiles (Foraminifères Benthiques et Algues Calcaires) en Relation avec leurs Microfaciès Carbonifères dans le Sahara Nord-ouest Algérien (bassins de Béchar, Reggane et Tindouf). Unpublished PhD Thesis, 01/2000, University Houari-Boumédienne, Algiers.

Sebbar, A. and Lys, M. 1989. Biostratigraphie du Carbonifère inférieur: Serpoukhovien du Djebel Arlal, Bassin de Béchar (Algérie). Revue de Micropaléontologie, 32:53-62.

Sebbar, A. and Mamet, B.L. 1996. Algues benthiques calcaires du Carbonifère inférieur et moyen du bassin de Béchar, Algérie. Revue de Micropaléontologie, 39:153-167. https:// doi.org/10.1016/s0035-1598(96)90044-6

Sebbar, A. and Mamet, B.L. 1999. Algues benthiques calcaires et Incertae sedis du Carbonifère, bassin de "Béchar-Mézarif", Algérie. Rôle sédimentologique. Revue de Micropaléontologie, 42:71-82. https://doi.org/10.1016/s0035-1598(99)90197-6

Selli, R. 1963. Schema geologico delle Alpi Carniche e Giulie occidentali. Giornale di Geologia, 30:1-136. 
Senowbari-Daryan, B. 1984. Mikroproblematika aus den obertriadischen Riffkalken von Sizilien. Münstersche Forschungen zur Geologie und Paläontologie, 61:1-81.

Senowbari-Daryan, B. 2013. Tubiphytes Maslov, 1956 and description of similar organisms from Triassic reefs of the Tethys. Facies, 59:75-112. https://doi.org/10.1007/s10347-012-0353-x

Senowbari-Daryan, B. and Flügel, E. 1993. Tubiphytes Maslov, an enigmatic fossil: Classification, fossil record and significance through time, part I: Discussion of Late Paleozoic material, p. 353-382. In Barattolo F., De Castro, P., and Parente, M. (eds.), Studies on Fossil Benthic Algae. Bolletino della Società Paleontologica Italiana, Special Volume No. 1, Modena.

Senowbari-Daryan, B. and Rashidi, K. 2010. The codiacean genera Anchicodium Johnson, 1946 and Iranocodium nov. gen. from the Permian Jamal Formation of Shotori Mountains, northeast Iran. Rivista Italiana di Paleontologia e Stratigrafia, 116:3-21.

Senowbari-Daryan, B. and Schäfer, P. 1980. Abatea culleiformis n. gen. n. sp., eine neue Rotalge (Gymnocodiacea) aus den "oberrhätischen" Riffkalken südlich von Salzburg (Nördliche Kalkalpen, Österreich). Verhandlungen der Geologischen Bundesanstalt, 1979:393-399.

Senowbari-Daryan, B. and Di Stefano, P. 1988. Microfacies and sphinctozoan assemblage of some Lower Permian breccias from the Lercara Formation (Sicily). Rivista Italiana di Paleontogia e Stratigrafia, 94:3-34.

Senowbari-Daryan, B., Keupp, H., Abate, B., and Vartis-Matarangas, M. 2002. First report of Norithamnium gen. nov. (Corallinales, Rhodophyta) from the Late Triassic (Norian-Rhaetian) reefs of the western Tethys, p. 201-208. In Bucur, I.I. and Filipescu, S. (eds.), Research Advances in Calcareous Algae and Microbial Carbonates. Cluj University Press, Cluj.

Senowbari-Daryan, B., Torabi, H., and Rashidi, K. 2008. New solenoporaceans from Upper Triassic ?Norian-Rhaetian reef limestones in central Iran. Geologica Croatica, 61:135-157.

Senowbari-Daryan, B. and Zamparelli, V. 2005. Triassic halimedaceans: New genera and species from the Alps, Sicily and southern Apennines. Revista Española de Micropaleontología, 37:141-169.

Sha Jin-geng, Zhang Lin-xin, Luo Hui, Xu Shang-hong, and Bao Hui-ming 1992. On the closure age of the Late Palaeozoic rift in Hohxil, Qinchai. Acta Micropaleontologica Sinica, 9:177182.

Shen, J.W. and Kawamura, T. 2001. Guadalupian algae-sponge reefs in siliciclastic environments - The reefs at Lengwu (South China) compared with the reef at Iwaizaki (Japan). Facies, 45:137-156. https://doi.org/10.1007/bf02668108

Shen, J.W. and Webb, G.E. 2004. Famennian (Upper Devonian) calcimicrobial (Renalcis) reef at Miaomen, Guilin, Guangxi, South China. Palaeogeography, Palaeoclimatology, Palaeoecology, 204:373-394. https://doi.org/10.1016/s0031-0182(03)00737-5

Shuysky, V.P. 1973. Izvestkovye Rifoobrazuyuschchie Vodorosli Nizhnego Devona Urala. Akademiya Nauk SSSR, Uralskii Nauchnyi Tsentr, Institut Geologii i Geokhimii: 1-119, Sverdlovsk. (In Russian)

Shuysky, V.P. 1987. Sistema nadrodovykh taksonov iskopaemykh izvestkovykh vodoroslei classa Siphonophyceae, p. 33-40. In Amon E.O. (ed.), Geologiya i Paleontologiya Urala. Akademiya Nauk SSSR, Uralskii Nauchnyi Tsentr, Institut Geologii i Geokhimii (1986), Sverdlovsk. (In Russian)

Shuysky, V.P. and Patrunov, D.K. 1991. Izvestkovye Vodorosli Nizhnego i Srednego Devona Yuga Novoi Zemli. Akademiya Nauk SSSR, Uralskoe Otdelenie, Institut Geologii i Geokhimii, Nauka: 1-80, Sverdlovsk. (In Russian)

Silva, P.C. and Johansen, H.W. 1986. A reappraisal of the order Corallinales (Rhodophyceae). British Phycological Journal, 21:245-254. https://doi.org/10.1080/00071618600650281

Skinner, J.W. and Wilde, G.L. 1966. Permian fusulinids from Pacific northwest and Alaska. The University of Kansas Paleontological Contributions, 4(4):1-64.

Skompski, S. 1996. Stratigraphic position and facies significance of the limestone bands in the subsurface Carboniferous succession of the Lublin Upland. Acta Geologica Polonica, 46:171-268.

Sokač, B., Bajraktarević, Z., and Jurisić-Polsak, Z. 1997. Academician Milan Herak's main contribution to palaeontology. Geologia Croatica, 50:143-146.

Sokač, B. and Grgasović, T. 1998. Asterocalculus heraki n. gen. n. sp., a new calcareous alga (Gymnocodiaceae) from the Upper Triassic Hauptdolomite of Zumberak, North Croatia. Facies, 38:197-206. https://doi.org/10.1007/bf02537365 
Soreghan, G.S. and Giles, K.A. 1999. Facies character and stratal responses to accomodation in Pennsylvanian bioherms, western Orogrande basin, New Mexico. Journal of Sedimentary Research, 69:893-908. https://doi.org/10.2110/jsr.69.893

Sremać, J. 2007. The Palaeozoic of Velebit, p. 13-19. In Grgasović, T. and Vlahović, I. (eds.), Field Trip Guidebook and Abstracts. Hrvastski Geoloski Institut (Croatian Geological Survey), 9th international Symposium on Fossil Algae, Croatia.

Stanier, R.Y. 1974. Division I. The Cyanobacteria, p. 22. In Buchanan, R.E. and Gibbons, N.E. (eds.), Bergey's Manual of Determinative Bacteriology. 8th Edition, Williams \& Wilkins Co., Baltimore.

Stephens, N.P. and Sumner, D.Y. 2002. Renalcids as fossilized biofilm clusters. Palaios, 17:225236. https://doi.org/10.1669/0883-1351(2002)017\%3C0225:rafbc\%3E2.0.co;2

Termier, G., Termier, H., and Vachard, D. 1977. Etude comparative de quelques Ischyrosponges. Géologie Méditerranéenne, 4:139-180.

Termier, H., Termier, G., and Vachard, D. 1975. Recherches micropaléontologiques dans le Paléozoïque supérieur du Maroc Central. Cahiers de Micropaléontologie, 4:1-99.

Termier, H., Termier, G., and Vachard, D. 1977. Monographie paléontologique des affleurements permiens du Djebel Tebaga (Sud Tunisien). Palaeontographica, A, 156:1-109.

Tillman, R.W. 1971. Petrology and paleoevironments, Robinson Member, Minturn Formation (Desmoinesian), Eagle Basin, Colorado. American Association of Petroleum Geologists Bulletin, 55:593-620. https://doi.org/10.1306/5d25cfd9-16c1-11d7-8645000102c1865d

Toomey, D.F. 1980. History of a Late Carboniferous phylloid algal bank complex in northeastern New Mexico. Lethaia, 13:249-267. https://doi.org/10.1111/j.1502-3931.1980.tb00639.x

Toomey, D.F. 1983a. The paleoecology of a "Middle Limestone Member" (Leavenworth) of an Upper Carboniferous (Stephanian) cyclothem, midcontinent, U.S.A. Facies, 8:113-190. https://doi.org/10.1007/bf02536741

Toomey, D.F. 1983b. Early Permian coated grains from a lagoonal environment, Laborcita Formation, southcentral New Mexico, U.S.A., p. 259-275. In Peryt T.M. (ed.), Coated Grains. Springer Verlag, Berlin-Heidelberg.

Toomey, D.F. 1991. Late Pennsylvanian phylloid-algal bioherms, Orogrande basin, SouthCentral New Mexico and West Texas, p. 213-220. In Barker, J.M. (ed.), Geology of the Sierra Blanca, Sacramento and Capitan Ranges, New Mexico. New Mexico Geological Society Guidebook, 42nd Field Conference, Sierra Blanca, Sacramento, Capitan Ranges, 1991, Socorro and Albuquerque.

Toomey, D.F., Wilson, J.L., and Rezak, R. 1977. Evolution of Yucca mound complex, Late Pennsylvanian phylloid algal buildup, Sacramento Mountains, New Mexico. American Association of Petroleum Geologists Bulletin, 61:2115-2133. https://doi.org/10.1306/ c1ea47d4-16c9-11d7-8645000102c1865d

Toomey, D.F. and Winland, H.D. 1973. Rock and biotic facies associated with Middle Pennsylvanian (Desmoinesian) algae buildup, Nena Lucia Field, Nolan County, Texas. American Association of Petroleum Geologists Bulletin, 57:1053-1074. https://doi.org/ 10.1306/83d90e53-16c7-11d7-8645000102c1865d

Torres, A.M. 1995. Ivanovia tebagaensis was a cyathiform codiacean membranous alga with dimorphic cortices. Journal of Paleontology, 69:381-387. https://doi.org/10.1017/ s0022336000034703

Torres, A.M. 1999. A three-dimensional CT (CAT) scan through a rock Permian alga Ivanovia tebagaensis. Journal of Paleontology, 73:154-158. https://doi.org/10.1017/ s002233600002761x

Torres, A.M. 2003. Sexual reproductive structures in the green alga Ivanovia triassica. Lethaia, 36:33-40. https://doi.org/10.1080/00241160310001236

Torres, A.M. and Baars, D.L. 1992. Anchicodium Johnson: Branched or phylloid. Journal of Paleontology, 66:675-677. https://doi.org/10.1017/s0022336000024525

Torres, A.M., Christensen, A.M., Masters, T.E., and Ketcham, R.A. 2003. From CT scans of embedded Ivanovia to models using rapid prototyping. Palaeontology, 46:839-843. https:// doi.org/10.1111/1475-4983.00321

Torres, A.M., West, R.R., and Sawin, R.S. 1992. Calcipatera cottonwoodensis, a new membranous Late Paleozoic alga. Journal of Paleontology, 66:678-681. https://doi.org/ $10.1017 / \mathrm{s} 0022336000024537$

Twenhofel, W.H. 1919. Pre-Cambrian and Carboniferous algal deposits. American Journal of Sciences, 48:339-352. 
Vachard, D. 1977a. Algues et pseudo-algues du Viséen-Serpoukhovien du Sud de la France (Montagne Noire, Pyrénées). Annales de la Société Géologique du Nord, 96(1976):373-378.

Vachard, D. 1977b. Etude stratigraphique et micropaléontologique (algues et foraminifères) du Viséen de la Montagne Noire (Hérault, France). Mémoires Institut Géologique Université Louvain, 29:111-195.

Vachard, D. 1980. Téthys et Gondwana au Paléozoïque supérieur; les données afghanes: biostratigraphie, micropaléontologie, paléogéographie. Documents et Travaux IGAL, Institut Géologique Albert de Lapparent, 2:1-463.

Vachard, D. 1985. Remarques sur les Dasycladales (Algues vertes) du Permien supérieur du Djebel Tebaga. Premier Congrès National des Sciences de la Terre, Tunis 1981, 1:271-281.

Vachard, D. 1988. Pour une classification raisonnée et raisonnable des Archaediscidae (Foraminifera, Carbonifère inférieur-moyen). Revue de Paléobiologie, volume spécial $n^{\circ} 2$, Benthos' 86:103-123.

Vachard, D. 1989. A rich algal microflora from the Lower Permian of Jambi Province, p. 59-69. In Fontaine, H. and Gafoer, S. (eds.), The Pre-Tertiary Fossils of Sumatra and their Environments. CCOP Technical Publication, 19, Bangkok and Tokyo.

Vachard, D. 1990. New data on foraminifera, algae and pseudo-algae of the Viséan and Bashkirian (Lower-Middle Carboniferous) from Northeast Thailand. Geologisches Jahrbuch, B73:91-109.

Vachard, D. 1993. Algues, pseudo-algues et microfaciès carbonatés du Dévonien du domaine Ligérien (Massif Armoricain, France). Palaeontographica, B, 229(1-3):53-113.

Vachard, D. 2016a. Macroevolution and biostratigraphy of Paleozoic foraminifers, p. 257-323. In Montenari, M. (ed.), Stratigraphy \& Timescales, 1. Elsevier, Amsterdam; https://doi.org./ 10.1016/bs.sats.2016.10.005

Vachard, D. 2016b. Permian smaller foraminifers: Taxonomy, biostratigraphy and biogeography, p. 205-252. In Lucas, S.G. and Shen, S.Z. (eds.), The Permian Timescale. Geological Society of London, Special Publications, 450; https://doi.org/10.1144/SP450.1

Vachard, D. and Beckary, S. 1991. Algues et foraminifères bachkiriens des coal balls de la Mine Rosario (Truebano, Léon, Espagne). Revue de Paléobiologie, 10:315-357.

Vachard, D., Clift, P., and Decrouez, D. 1993a. Une association à Pseudodunbarula (Fusulinoïde) du Permien supérieur (Djoulfien) remaniée dans le Jurassique d'Argolide (Grèce). Revue de Paléobiologie, 12:217-242.

Vachard, D. and Cózar, P. 2010. An attempt of classification of the Palaeozoic incertae sedis Algospongia. Revista Española de Micropaleontología, 42:129-241.

Vachard, D., Cózar, P., Aretz, M., and Izart, A. 2016. Late Viséan-early Serpukhovian cyanobacteria and algae in the Montagne Noire (France): Taxonomy and biostratigraphy. Bulletin of Geosciences, 91:433-466. https://doi.org/10.3140/bull.geosci.1613

Vachard, D., Fontaine, H., and Caridroit, M. 1992. Foraminifera, algae and pseudo-algae from Carboniferous and Permian of northwest Thailand. Revue de Paléobiologie, 11:137-147.

Vachard, D., Fourcade, E., Romero, J.E., Mendez, J.E, Cosillo, A., Alonzo, M., Requeña, J., Azema, J., and Cros, P. 1997. Foraminifères et algues du Permien du Guatemala. Geobios, 30:745-784. https://doi.org/10.1016/s0016-6995(97)80177-5

Vachard, D., Gaillot, J., Vaslet, D., and Le Nindre, Y.M. 2005. Foraminifers and algae from the Khuff Formation (late Middle Permian-Early Triassic) of central Saudi Arabia. GeoArabia, 10:137-186.

Vachard, D., Gargouri-Razgallah, S., and Chaouachi, M.C. 1989a. Sur les biohermes à algues solénoporacées et phylloïdes du Permien supérieur de Tunisie (Murghabien du Djebel Tebaga) et sur les incidences de la diagenèse carbonatée sur la systématique algaire. Revue de Paléobiologie, 8:121-141.

Vachard, D., Haig, D.W., and Mory, A.J. 2014. Lower Carboniferous (middle Visean) foraminifers and algae from an interior sea, Southern Carnarvon Basin, Australia. Geobios, 47:57-74; supplementary material. https://doi.org/10.1016/j.geobios.2013.10.005

Vachard, D., Hauser, M., Martini, R., Zaninetti, L., Matter, A., and Peters, T. 2001a. New algae and problematica of algal affinity from the Permian of the Aseelah Unit of the Batain Plain, (East Oman). Geobios, 34:375-404. https://doi.org/10.1016/s0016-6995(01)80003-6

Vachard, D. and Kabanov, P. 2007. Palaeoaplysinella gen. nov. and Likinia Ivanova and Ilkhovskii, 1973 emend. from the type Moscovian (Russia) and the algal affinities of the ancestral Palaeoaplysinaceae n. comb. Geobios, 40:849-860. https://doi.org/10.1016/ j.geobios.2007.01.006 
Vachard, D. and Krainer, K. 2001a. Smaller foraminifers of the Upper Carboniferous Auernig Group, Carnic Alps (Austria/Italy). Rivista Italiana di Paleontologia e Stratigrafia, 107:147168.

Vachard, D. and Krainer, K. 2001b. Smaller foraminifers, characteristic algae and pseudo-algae of the latest Carboniferous/Early Permian Rattendorf Group, Carnic Alps (Austria/Italy). Rivista Italiana de Paleontologia e Stratigrafia, 107:169-195.

Vachard, D., Krainer, K., and Lucas, S. 2012. Pennsylvanian (Late Carboniferous) calcareous microfossils from Cedro Peak (New Mexico, USA); Part 1: Algae and Microproblematica. Annales de Paléontologie, 98:225-252. https://doi.org/10.1016/j.annpal.2012.06.003

Vachard, D., Krainer, K., and Lucas, S.G. 2015. Late Early Permian (late Leonardian; Kungurian) algae, microproblematica, and smaller foraminifers from the Yeso Group and San Andres Formation (New Mexico; USA). Palaeontologia Electronica 18.1.21A:1-77. https://doi.org/ $10.26879 / 433$ palaeo-electronica.org/content/2015/1160-kungurian-of-new-mexico

Vachard, D., Laveine, J.P., Zhang, S.Z., Deng, G., and Lemoigne, Y. 1991. Calcareous microfossils (foraminifers, algae, pseudo-algae) from the Uppermost Viséan of Jiu Hu near Guangzhou (Canton), People's Republic of China. Geobios, 24:675-681. https://doi.org/ 10.1016/s0016-6995(06)80295-0

Vachard, D., Martini, R., Zaninetti, L., and Zambetakis-Lekkas, A. 1993b. Révision micropaléontologique (Foraminifères, Algues) du Permien inférieur (Sakmarien) et supérieur (Dorashamien) du Mont Beletsi (Attique, Grèce). Bolletino della Societá Paleontologica Italiana, 32:89-112.

Vachard, D., Martini, R., and Zaninetti, L. 2001b. Earliest Artinskian (Early Permian) fusulinid reworked in the Triassic Lercara Formation (NW Sicily). Journal of Foraminiferal Research, 31:33-47. https://doi.org/10.2113/0310033

Vachard, D. and Maslo, A. 1996. Précisions biostratigraphiques et micropaléontologiques sur le Bashkirien d'Ukraine (Carbonifère moyen). Revue de Paléobiologie, 15:357-383.

Vachard, D. and Miconnet, P. 1990. Une association à Fusulinoïdes du Murghabien supérieur au Monte Facito (Appennin méridional, Italie). Revue de Micropaléontologie, 32:297-318.

Vachard, D. and Moix, P. 2011. Late Pennsylvanian to Middle Permian revised algal and foraminiferan biostratigraphy and palaeobiogeography of the Lycian Nappes (SW Turkey): Palaeogeographic implications. Revue de Micropaléontologie, 54:141-174. https://doi.org/ 10.1016/j.revmic.2011.02.002

Vachard, D. and Moix, P. 2013. Kubergandian (Roadian, Middle Permian) of the Lycian and Aladag Nappes (Southern Turkey). Geobios, 46:335-356. https://doi.org/10.1016/ j.geobios.2013.02.002

Vachard, D. and Montenat, C. 1981. Biostratigraphie, micropaléontologie et paléogéographie du Permien de la région de Tezak (Montagnes Centrales d'Afghanistan). Palaeontographica, $B$, 178:1-88.

Vachard, D., Perret, M.-F., and Delvolvé, J.-J. 1989b. Algues, pseudo-algues et foraminifères des niveaux bachkiriens dans les secteurs d'Escarra et Aragon Subordan (Pyrénées aragonaises, Espagne). Geobios, 22:697-723. https://doi.org/10.1016/s00166995(89)80068-3

Vachard, D., Pille, L., and Gaillot, J. 2010. Palaeozoic Foraminifera: Systematics, palaeoecology and responses to the global changes. Revue de Micropaléontologie, 53:209-254. https:// doi.org/10.1016/j.revmic.2010.10.001

Vachard, D. and Razgallah, S. 1988. Survie des genres Tharama et Renalcis (Epiphytales, algues problématiques) dans le Permien supérieur du Djebel Tebaga (Tunisie). Comptes Rendus de l'Académie des Sciences de Paris, 306:1137-1140.

Vachard, D., Vandelli, A., and Moix, P. 2013. Discovery of the Misellina Zone (latest Kungurian) in the Lentas unit of the Pindos Series (Crete). Geobios, 46:521-537. https://doi.org/10.1016/ j.geobios.2013.06.003

Vachard, D., Zambetakis-Lekkas, A., Skourtsos, E., Martini, R., and Zaninetti, L. 2003. Foraminifera, algae and carbonate microproblematica from the late Wuchiapingian/Dzhulfian (Late Permian) of Peloponnesus (Greece). Rivista Italiana di Paleontologia e Stratigrafia, 109:339-358.

Venturini, C. 1982. II bacino tardoercinico di Pramollo (Alpi Carniche): Un evoluzione regolata dalla tettonica sinsedimentaria. Memorie Società Geologica Italiana, 24:23-42. 
Venturini, C. 1990a. Field Workshop on Carboniferous to Permian Sequence of the PramolloNassfeld Basin (Carnic Alps). Guidebook:1-159, Arti Grafiche Friulane, Udine.

Venturini, C. 1990b. Geologia delle Alpi Carniche centro-orientali. Edizione del Museo Friulano di Storia Naturale, Publication 36, Udine.

Venturini, C. 1991. Introduction to the geology of the Pramollo Basin (Carnic Alps) and its surroundings, p. 13-47. In Venturini, C. (ed.), Workshop Proceedings on Tectonics and Stratigraphy of the Pramollo Basin (Carnic Alps). Giornale di Geologia, ser. 3a, 53, Bologna.

Vologdin, A.G. 1932. Arkheotsiaty Sibiri. Gosudarstvennoe Nauchno-Tekhnicheskoe GeologoRazvedocne Izdateltsvo 2: Fauna kembriskikh izvestiyakov Altaya, Moscow-Leningrad. (In Russian)

Wahlman, G.M. 1988. Subsurface Wolfcampian (Lower Permian) shelf-margin reefs in the Permian Basin of West Texas and Southeastern New Mexico. Midcontinent Society for Economic Paleontologists and Mineralogists, Special Publication, 1:177-204.

Wahlman, G.P. 2002. Upper Carboniferous-Lower Permian (Bashkirian-Kungurian) mounds and reefs, p. 271-338. In Kiessling, W., Flügel, E., and Golonka, J. (eds.), Phanerozoic Reef Patterns. SEPM Special Publication, 72, Tulsa. https://doi.org/10.2110/pec.02.72.0271

Wahlman, G.P., Orchard, D.M. and Bujs, G.J. 2013. Calcisponge-microbialite reef facies, middle Permian (lower Guadalupian), northwest shelf margin of Permian Basin, New Mexico. AAPG Bulletin, 97:1896-1919. https://doi.org/10.1306/07091313020

Wahlman, G.P. and Tasker, D.R. 2013. Lower Permian (Wolfcampian) carbonate shelf-margin and slope facies, Central Basin Platform and Hueco Mountains, Permian Basin, West Texas, USA. SEPM Special Publication, 105:305-333. https://doi.org/10.2110/sepmsp.105.09

Wang, S.H., Fan, J.S., and Rigby, J.K. 1994. Archaeolithoporella and Tubiphytes: Affinities and palaeoecology in Permian reefs of South China. Science in China, 37:723-743. (In Chinese)

Weidlich, O. 2002. Middle and Upper Permian reefs-distributional patterns and reservoir potential, p. 339-390. In Kiessling, W., Flügel, E., and Golonka J. (eds.), Phanerozoic Reef Patterns. SEPM Special Publication, 72, Tulsa.

Wendt, J. 1997. Aragonitic dasycladalean algae from the Upper Permian of Sichuan, China. Lethaia, 29:361-368. https://doi.org/10.1111/j.1502-3931.1996.tb01671.x

West, R.R. 1988. Temporal changes in Carboniferous reef mound communities. Palaios, 3:152169. https://doi.org/10.2307/3514527

Wethered, E. 1886. On the structure and organisms of the Lower Limestone Shales, Carboniferous Limestone and Upper Limestones of the Forest of Dean. Geological Magazine, 23:529-534.

Wethered, E. 1890. On the occurrence of the genus Girvanella in oolitic rocks and remarks on oolitic structure. Quarterly Journal Geological Society, 46:270-281.

Wettstein, R.R. 1901. Handbuch der systematischen Botanik, Vol. 1. Deuticke, Leipzig.

Wilson, J.L. 1975. Carbonate Facies in Geologic History. Springer-Verlag, Berlin.

Wood, A. 1940. Two new calcareous algae of the family Dasycladaceae from the Carboniferous Limestone. Proceedings Liverpool Geological Society, 18:14-18.

Wood, A. 1941. The Lower Carboniferous calcareous algae Mitcheldeania Wethered and Garwoodia gen. nov. Proceedings of the Geological Association, 52:216-226.

Wray, J.L. 1964. Archaeolithophyllum, an abundant calcareous alga in limestones of the Lansing Group (Pennsylvanian), southeastern Kansas. Kansas Geological Survey, Bulletin 170(1):113.

Wray, J.L. 1967. Upper Devonian calcareous algae from the Canning Basin, Western Australia. Colorado School of Mines, Professional Contributions, 3:1-76.

Wray, J.L. 1968. Late Paleozoic phylloid algal limestone in the United States. 23th International Geological Congress, (Prague), Proceedings, 8:113-119.

Wu, Y.S. 1991. Calcareous algae from Permian reefs of Longhin, Guangxi, China. Acta Paleontologica Sinica, 30:750-767.

Zagorodnyuk, P.A. 1979. Vodorosli, p. 6-12. In Einor, O.L. (ed.), Atlas Fauny i flory Srednegopoznego Karbona Bashkirii. Moscow, Nedra. (In Russian)

Zanin Buri, C. 1965. A new Permian Epimastopora (calcareous algae) from Hunza Valley (western Karakorum), p. 79-88. In Amiot, M., Ciry, R., Fantini Sestini, N., Premoli Silva, I., Rossi Ronchetti, C., Sartenaer, P., Vandencammen, A., Schouppé, A. von, and Zanin Buri C., Fossils of Karakorum and Chitral. In Italian Expeditions to the Karakorum (K2) and Hindu Kush, 1, 1st part, E.J. Brill, Leiden. 
Zaninetti, L. 1978. Un organisme incertae sedis nouveau dans le Permien du Sud-Zagros, Iran. Notes du Laboratoire de Paléontologie de l'Université de Genève, 3:17-19.

Zaninetti, L., Brönnimann, P., Huber, H., and Moshtaghian, A. 1978. Microfaciès et microfaunes du Permien au Jurassique au Kuh-e Gahkum, Sud-Zagros, Iran. Rivista Italiana di Paleontologia, 84:865-896.

Zhao, J.K., Sheng, J.Z., Yao, Z.Q., Liang, X.L., Chen, C.Z., Rui, L., and Liao, Z.T. 1981. The Changhsingian and Permian-Triassic boundary of South-China. Bulletin Nanjing Institute Geology and Paleontology, Academia Sinica, 2:58-69. (In Chinese with English abstract) 